\title{
ESCOLA PROMOTORA DE SAÚDE: \\ QUEM SABE FAZ A HORA!
}

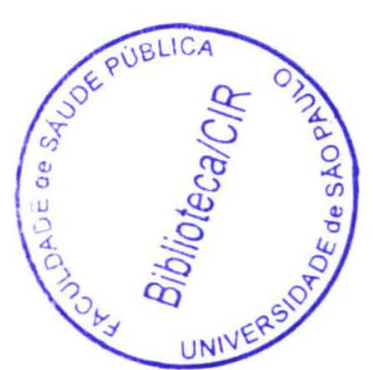

GHISLEINE TRIGO SILVEIRA

Tese de Doutorado apresentada ao Departamento de Prática de Saúde Pública da Faculdade de Saúde Pública da Universidade de São Paulo para obtenção do Grau de Doutor.

Área de concentração:

Serviços de Saúde Pública.

Orientadora: Profa. Dra Isabel Maria Teixeira Bicudo Pereira

São Paulo 
Autorizo, exclusivamente para fins acadêmicos e científicos, a reprodução total ou parcial desta tese, por processos fotocopiadores.

Assinatura:

Data:

\section{$40206 / 2000$ doc}


Ȧ MEMÓRIA DE MEUS PAIS

AOS QUE FAZEM DA ESCOLA PÚBLICA A SUA VIDA 


\section{A G R A D E C I M E N T OS}

Em primeiro lugar, à minha orientadora, que me estimulou continuamente na elaboração e apresentação deste trabalho. Aliás, não fossem a sua reconhecida competência silenciosa e personalidade privilegiada, eu certamente teria ficado pelo meio do caminho...

Ao Prof. Sílvio Lima Rocha, Dirigente da Diretoria Estadual de Ensino de Carapicuíba, que tão prontamente me auxiliou na seleção de uma escola com a marca da diferença, ou seja, de uma escola que não tem nenhuma crise de identidade sobre o que significa oferecer educação pública de boa qualidade.

À prof.a. Maria Aparecida dos Santos Martins, diretora da Escola Estadual de Educação "Victório Fornasaro", pela competência e prontidão com que acolheu a proposta de realização deste estudo e mobilizou a equipe escolar para que dela participasse.

Às professoras e professores que se envolveram inteiramente com esta investigaçào e não hesitaram em externar suas reflexões acerca do tema investigado, sobre a sua atuação profissional e sobre a escola na qual atuam.

A querida amiga, Lucy Helena Baptista Teixeira, pela dedicação e paciência na transcrição das entrevistas.

Finalmente. à Gaby e à Ciça, que têm enchido a minha vida de especial carinho. 


\section{RESUMO}

Silveira GT. Escola promotora de saúde: quem sabe faz a hora! São Paulo; 2000. [Tese de Doutorado- Faculdade de Saúde Pública da USP]

A tese deste trabalho é a de que o processo de implementação de projetos de promoção de saúde nas escolas pode ser decodificado a partir das representações sociais que seus diversos protagonistas têm a respeito do que seja saúde, doença, promoção de saúde e, principalmente, das interseções a serem estabelecidas entre escola e promoção de saúde e da relação entre escola e comunidade. Ou seja, parte-se do princípio de que, à medida que se começa a desvendar o universo dessas representações sociais, pode-se vislumbrar as possiveis articulações entre elas e a prática cotidiana das escolas que resulta em ações efetivas de promoção da saúde. Para verificar se esta tese se sustenta, este estudo investigou como se dá, na prática, a implementação do projeto de uma escola promotora de saúde, identificando alguns aspectos desta implementação - tais como o perfil da direção da escola, a sua arquitetura e espaços pedagógicos, os seus padrões de rendimento escolar - e levantando as representações sociais dos protagonistas deste processo. $O$ estudo realizou-se numa escola da rede estadual paulista, localizada na cidade de Carapicuíba, na região metropolitana de São Paulo, que oferece Ensino Fundamental e Médio a, aproximadamente, 2000 alunos.

A metodologia utilizada foi de orientação qualitativa, recorrendo-se ao aprofundamento das falas dos sujeitos, na perspectiva de compreender os significados por eles atribuídos às vivências experimentadas na escola e, com isso, a identificação das estratégias correlacionadas à efetiva promoção de saúde. Os dados obtidos por meio de entrevistas foram submetidos à análise, buscando-se as categorias principais nelas reveladas e suas expressões-chave. Chegou-se, finalmente, aos discursos do sujeito coletivo, ressaltandose as estratégias e/ou variáveis que têm permitido à escola se caracterizar como promotora de saúde, segundo a concepção de promoção de saúde explicitada nos atuais parâmetros curriculares nacionais para o Ensino Fundamental. Em síntese, despontam como fatores fundamentais para que a escola se firme como promotora de saúde a sua 
efetiva capacidade de elaborar e implementar um projeto coletivo de trabalho - inclusive com a participação constante da comunidade - e o empenho e a habilidade de sua direção em liderá-lo, permitindo que a escola ofereça aos usuários ambientes físicos adequados e conservados, ensino de boa qualidade e vivência de práticas de saúde. Tais condições, por sua vez, asseguram que a escola funcione como uma referência de qualidade de vida para alunos, corpo docente e comunidade escolar, exigindo dela perseverança, compromisso, profissionalismo e seriedade. 


\begin{abstract}
Silveira GT. Health promoting school: the opportunity of information. São Paulo; 2000. [PhD paper - Public Health School, University of São Paulo ]
\end{abstract}

The main argument of this study is that the process of installation of a health promoting project in schools can be decoded by the different actors involved according to their social representations of the meanings of health, ilnesss, health promotion and, mainly, by the intersections that can be established between school and health promotion and by the relations between school and community. In other words, the starting point is the principle that, as one begins to unveil the universe of such social representations, one can see the outlines of the possible articulations between them and the daily practice of schools, which result in effective actions in health promotion. In order to establish the feasebility of this argument, this study investigated how the implementation of a health promoting project in school, occurs in pratice, by identifying some of its aspects, such as the profile of the scool head, the architecture and its pedagogic spaces, the patterns of school performance - and surveying the social representations social of the actors, in this process. The study took place in a state public school, located in the city of Carapicuiba, in the metropolitan region of the city of São Paulo, wich offers fundamental and secondary education to aproximately 2 thousand students.

The metodology was of qualitative nature, deepening the analysis of the verbal manifestations of the subject, focusing the comprehension of the meanings the subject attributed to the life experiences in school and, thus, the identification of strategies correlated to the real promotion of health. The data obtained through interwiews were object of analysis, in search of the main categories therein revealed, as well as the key expressions. Finally, one arrived to the discourse of the collective subject, sressing the strategies and/or variables that have permitted the characterization of the school as a health promoter, according to the concept of health promotion, such as explicit in the current national parameters for Fundamental Education. To sum up, factors wich arise as basic to allow a school to become firm as health promoter are its real capacity to create and implement a collective work project - including the constant participation of the 
community -, the effort and hability of the school head to lead it, assuring good material conditions, learning and life experience of health practices, in the sense that the school should act as a life quality reference to its students, its teaching staff and school community, in a process that demands continuity and perseverance. 


\section{ÍNDICE}

INTRODUÇÃO

\section{CAPÍTULO I - CONSTRUINDO O QUADRO TEÓRICO}

\section{REFERENCIAL}

A. A evolução do conceito "promoção de saúde" ...................................... 8

B. Saúde escolar, promoção de saúde e escolas promotoras de saúde ......... 11

C. A promoção da saúde na perspectiva dos novos parâmetros curriculares para o Ensino Fundamental

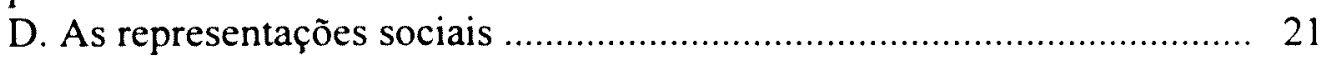

E. Curriculo, espaço e subjetividade ........................................................ 23

F. Afinal, o que é uma escola de boa qualidade? ....................................... 24

CAPÍTULO II- METODOLOGIA …………………………………..... 28

A . Pressupostos teóricos ................................................................. 29

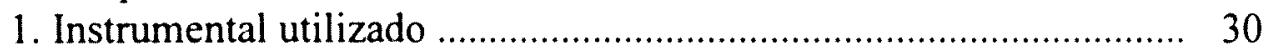

2. Análise dos depoimentos ....................................................... 30

B. Procedimentos metodológicos ........................................................... 34

1. Procedimentos para a coleta e transcrição dos dados ........................ 34

2. Procedimentos para a seleção dos sujeitos ...................................... 34

3. Procedimentos para a organização dos discursos e categorias .......... 35

4. Informações sobre os sujeitos ........................................................... 36

CAPÍTULO III - APRESENTANDO RESULTADOS ...................... 39

A . As categorias encontradas ......................................................... 40

B. As idéias centrais identificadas ....................................................... 41

C. O resgate do discurso do sujeito coletivo ............................................. 43

1. Por que a escola é uma boa escola? ................................................ 44

2. Por que a escola é uma escola saudável? ...................................... 47

3. Quais as relações de reciprocidade estabelecidas entre as categorias "boa escola" e "escola saudável" ................................... 52

4. Qual o papel da escola na área da saúde? ......................................... 53

5. Como a escola se transformou numa escola saudável? ..................... 57

CAPÍTULO IV - ANALISANDO E DISCUTINDO RESULTADOS .... 61

A. Conjugando qualidades: boa escola e escola saudável ........................... 62

B. A escola é saudável e atua como uma escola promotora de saúde .......... 63

C. A escola é, de fato, uma boa escola ................................................ 71

D. Fatores associados à atual identidade da escola .................................. 74

E. O fantasma da descontinuidade ...................................................... 77

CONSIDERAC̄ÕES FINAIS ou "ESCOLAS SAUDÁVEIS:

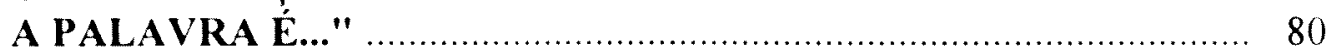




\author{
ANEXOS \\ Anexo 1- Localização da escola - mapa da região \\ Anexo 2- Caracterização da escola \\ Anexo 3- Roteiro da entrevista \\ Anexo 4- Composição da equipe escolar da escola investigada \\ Anexo 5-Categorias resultantes do reagrupamento das questões \\ da entrevista \\ Anexo 6- Temas e sub-temas referidos pelos sujeitos nas entrevistas \\ Anexo 7-Temas, sub-temas e Expressões-chave nos 12 discursos \\ Anexo 8-Idéias Centrais e Expressões-chave \\ Anexo 9- Fotografias da escola e trechos de Expressões- chave
}


INTRODUÇÃO 


\section{INTRODUÇÃO}

Durante o significativo periodo de minha atividade em escolas e órgãos centrais da Secretaria de Estado da Educação de São Paulo, tive inúmeras oportunidades de entrar em contato com diferentes escolas, muitas das quais, logo à primeira vista, eram sentidas como escolas que faziam diferença - e diferença para melhor.

Posteriormente, por ocasião da elaboração e defesa de minha dissertação de mestrado, defendida em 1994 nesta mesma Faculdade de Saúde Pública, entrei em contato mais sistemático com algumas escolas públicas, desta feita para investigar a situação do Ensino de saúde na rede pública estadual. Procurava, na ocasião, cotejar as concepções oficiais sobre Ensino de saúde, segundo documentos do Ministério da Educação e da Secretaria de Estado da Educação de São Paulo, às concepções de saúde expressas pelos professores dessas escolas e às suas práticas pedagógicas.

Logo de início, dei-me conta, por um lado, da riqueza do processo de investigação que toma como foco a prática escolar e dá voz aos protagonistas da educação na escola, aliás, os que fazem (ou não) com que as concepções oficiais ganhem o caminho da realidade ou da vida. Por outro, concluí que o estudo teria sido mais facilmente executado, com ganhos qualitativos, caso tivesse trabalhado com uma única escola.

Foi exatamente com estas convicções que iniciei o meu curso de Doutorado, em 1995, nesta mesma Faculdade: investigar como uma escola direciona o seu projeto de Educação em saúde, mais especialmente na área da educação ambiental.

No entanto, de 1995 para cá, o cenário teórico da saúde escolar passou por duas importantes mudanças que viriam a impactar consideravelmente esta proposta inicial. A primeira delas diz respeito à circulação mais intensa, no meio acadêmico brasileiro. do conceito de "promoção de saúde"1, provocando o que foi interpretado por muitos como

\footnotetext{
1 O conceito de "promoção de saúde" emergiu nas décadas de 70 e 80; as Conferências Internacionais sobre Promoção de Saúde, por sua vez. iniciaram-se em 1986, com a Conferência de Ottawa. No entanto, a despeito disso, a Educação em saúde na escola não assimilou imediatamente os reflexos deste novo paradigma, inclusive no que se refere aos seus aspectos teóricos.
} 
uma espécie de obscurecimento da Educação em saúde. ${ }^{2}$

A segunda mudança tem a ver com a Lei de Diretrizes e Bases da Educação Nacional, promulgada em 1996, e as ações desencadeadas pelo Ministério da Educação para implementá-la. Com efeito, este Ministério iniciou a elaboração de novos parâmetros curriculares, introduzindo uma novidade em termos do currículo brasileiro: além das áreas tradicionais, falava-se, agora, dos "temas transversais", entre os quais se incluía o tema "saúde". Tratava-se, sem dúvida, de uma mudança no panorama teórico do discurso oficial na área da educação, em particular, na área do que tradicionalmente se conhecia por "Ensino de saúde" ou "Educação em saúde".

Nestas circunstâncias, julguei que o meu projeto de dar continuidade ao que já iniciara no mestrado, agora, mais do nunca, seria plenamente realizado caso investigasse como os novos parâmetros curriculares estariam sendo apropriados na prática cotidiana de uma escola pública. Mais que isso: a despeito de que a experiência particular de uma escola seja única e, como tal, não possa ( e não deva) ser "transplantada" para outra, um estudo nesta linha poderia trazer uma contribuição para que este novo enfoque - escola enquanto um espaço natural de promoção da saúde - começasse a ser incorporado mais rapidamente no discurso e na prática escolar.

A nossa tese inicial era de que a implementação do projeto pedagógico de uma escola e, em particular, de um projeto que a aproxime de realizar o que chamaremos aqui de "promoção da saúde", dar-se-á segundo as representações sociais que os diversos protagonistas que atuam na escola têm a respeito do que seja saúde, do que seja educação e, principalmente, das interseções a serem estabelecidas entre saúde e educação e entre a família, a comunidade e a escola. Ainda: à medida que se começa a desvendar o universo dessas representações sociais, pode-se vislumbrar as possiveis articulações entre elas e a prática cotidiana da escola na área.

Tratava-se, pois, de trabalhar com uma boa escola, ou seja, com uma daquelas escolas que fazem diferença, verificando a natureza desta diferença e o quanto ela

\footnotetext{
2 Embora a promoção de saúde seja objeto especifico do capitulo II. cabe registrar aqui que este movimento, ao enfatizar fatores sociais, económicos e ambientais como determinantes da saúde, pode representar, na visðo de muitos teóricos, um instrumento mais efetivo e ágil de mudança do que representaria a Educação em saúde, quando esta tende a ficar confinada aos limites da escola.
} 
contribui para a promoção de saúde da comunidade escolar e, ainda, de que forma as representações sociais da equipe escolar impulsionam a escola na direção de ser uma boa escola.

O presente trabalho resultou das ações que tiveram como objetivo verificar a sustentabilidade de nossa tese inicial. Assim, no capitulo I, fez-se uma revisão de literatura, visando a construção de quadro teórico referencial que fornecesse os conteúdos necessários para planejar, realizar e analisar os resultados desta pesquisa. A discussão girou em torno de cinco eixos: o conceito de promoção de saúde, numa perspectiva histórica, os atuais parâmetros curriculares nacionais de saúde para o Ensino Fundamental, as indicações sobre o que significa ser uma boa escola pública, o entendimento das relações entre currículo, espaço e subjetividade e, finalmente, o conceito de representação social.

No capítulo II, definiu-se o caminho metodológico adotado, os seus pressupostos teóricos e os procedimentos observados na implementação desta pesquisa, explicitandose como se procedeu à coleta de dados e ao seu processo de análise, segundo o referencial de análise adotado. Caracterizou-se, ainda, a escola palco da investigação, para que se pudesse ter clareza sobre os motivos pelos quais ela vem sendo encarada como uma escola de boa qualidade.

No capítulo III, foram apresentados os resultados desta investigação, explicitando-se as expressões-chave dos depoimentos dos sujeitos entrevistados e, finalmente, o denominado Discurso do Sujeito Coletivo, no qual se pode reconhecer as representações sociais dos atores que são, na prática, os que iniciam e sustentam o processo de implementação gradativa de ações de promoção de saúde na escola.

No capitulo IV, retomam-se os resultados da investigação, agora para confrontálos com os referenciais teóricos previamente levantados, referentes à promoção da saúde e ao que se considera como caracteristicas de uma escola de boa qualidade.

No item "Considerações Finais". alguns pontos discutidos no Capitulo IV foram destacados, na crença de que possam concorrer para a consolidação de um referencial sobre as estratégias e/ou características que, no caso particular da escola investigada, contribuíram sobremaneira para o seu indiscutivel caráter de escola promotora de saúde 
Embora as limitações desta investigação sejam bastante evidentes, espera-se que as reflexões aqui registradas possam estimular novas discussões sobre a urgência de que a escola pública se renda de vez à democratização, desta vez realizando um real e efetivo trabalho de formar cidadãos comprometidos com a melhoria de sua qualidade de vida e da qualidade de vida da sua comunidade e do povo brasileiro. 


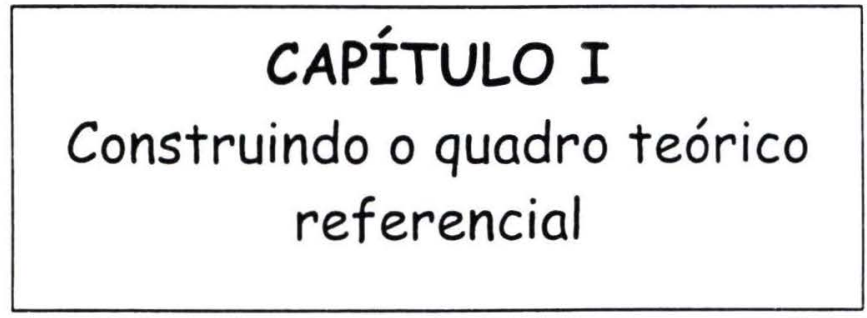




\section{CONSTRUINDO O QUADRO TEÓRICO REFERENCIAL}

De início, tratava-se de construir um quadro referencial que conferisse uma razoável tranqüilidade para transitar no que esta investigação chama de "promoção da saúde" e, ainda, quanto ao entendimento deste texto acerca das características ou estratégias de uma escola promotora de saúde. Para tanto, recorreu-se às concepções teóricas nesta área, na expectativa de que a clareza sobre o sentido dos conceitos aqui adotados funcionasse como uma espécie de fio condutor tanto para a estruturação e bom andamento da pesquisa, quanto para a comunicação de seus resultados.

Uma vez que se tem a conviç̧ão de que as escolas - e as equipes escolares convivem, de maneira geral, com um repertório bastante diversificado de sentidos e de açð̃es na área da saúde escolar - sentidos e ações que apareceram ao longo das relações estabelecidas historicamente entre a escola e a saúde - optou-se por sua apresentação numa perspectiva histórica e razoavelmente contextualizada. Julgou-se, ainda, indispensável recorrer às concepç̃oes oficiais de saúde escolar, explicitadas nas recentes publicações do Ministério da Educação.'

No entanto, é fundamental registrar que não houve - e não há - nenhuma intenção em desqualificar ${ }^{2}$ qualquer dos sentidos ou ações com os quais as escolas vêm lidando, muito menos em conferir maior qualidade às iniciativas que se identificam com os conceitos ou ações mais contemporâneos nesta área. Desta forma, a despeito de que o trabalho aponte as ações que têm contribuido para que a escola seja um instrumento efetivo para assegurar melhor qualidade de vida à comunidade, não se quer cometer o equívoco de elegê-las como intrinsecamente "positivas", postura que implicaria o

\footnotetext{
${ }^{1}$ Em 1997, a Secretaria de Educação Fundamental do Ministério da Educação publicou uma série de documentos contendo os parametros curriculares para o Ensino Fundamental, inclusive para a área de saúde.

"O termo "desqualificar" está sendo utilizado com um dos sentidos possiveis da "valoração" das escolas segundo as suas açðes na área da saúde. Nessa perspectiva. "desqualificar" uma escola seria atribuir-lhe, numa escala crescente de valores, valores mais baixos, coincidentes com as açðes que caracterizaram o início da história da saúde escolar, ou seja, numa perspectiva mais higienista, sanitarista ou individual.
} 
desconhecimento da historicidade na produção do conhecimento e da própria dinâmica de cada instituição, em especial, a da escola.

\section{A . A evolução do conceito "promoção de saúde"}

Os marcos conceituais históricos da promoção da saúde datam da década de 70 , com o conceito de "campo de saúde" expresso na proposta de atuação do Ministério da Saúde do Canadá. Ao mesmo tempo que a referida proposta critica a extrema valorização da tecnologia e das práticas centradas prioritariamente na oferta de serviços assistenciais - portanto, critica a ênfase na organização da atenção à saúde - indica que a atuação nesta área deve contemplar igualmente os aspectos relacionados à biologia humana, ao meio ambiente e aos estilos de vida. ${ }^{5}$

Ainda na década de 70, a Conferência Internacional de Alma-Ata sobre Cuidados Primários de Saúde reafirma, enfaticamente, que a obtenção do nível máximo possível de saúde requer a ação de muitos outros setores sociais e econômicos, além do setor saúde; além disso, firma-se o entendimento de que a saúde deve ser encarada como a mais importante meta social mundial, enquanto um estado de completo bem estar físico, mental e social - e não apenas a ausência de doença ou enfermidade. Com efeito, a saúde passa a ser interpretada como um direito humano fundamental e, neste sentido, contesta-se que o eixo articulador deste setor seja efetivamente o da organização de serviços de atenção sanitária.

Nas décadas seguintes, as Conferências de Saúde centraram suas discussões no paradigma da promoção de saúde e este conceito inicial passou a ser gradativamente explicitado. Assim, por exemplo, em 1986, na Conferência de Ottawa, define-se que "promoção de saúde é o nome dado ao processo de capacitação da comunidade para atuar na melhoria de sua qualidade de vida e saúde, incluindo uma maior participação no controle deste processo" (MINISTÉRIO DA SAÚDE 1997). Reconhece-se como prérequisitos para a saúde, a paz, o acesso à habitação, educação, alimentação, renda, ecossistema estável, recursos sustentáveis, justiça social e eqüidade. Por sua vez, de-

\footnotetext{
${ }^{5}$ A proposta introduzia o conceito de "campos de saúde", proposto por Marc Lalonde, então Ministro da Saúde do Canadá. entendidos como áreas obrigatórias de atuação e determinação da saúde.
} 
finem-se cinco campos de ação da promoção de saúde: a construção de políticas públicas saudáveis, a criação de ambientes favoráveis à saúde, o desenvolvimento de habilidades individuais, o reforço da ação comunitária e a reorientação dos serviços de saúde. É inegável que se ratifica, assim, uma visão integral de saúde, mas não se avança na explicitação do papel da escola na promoção da saúde. ${ }^{6} \mathrm{~A}$ bem da lógica, poder-se-ia esperar que as Conferências seguintes avançassem na definição dos campos de atuação para a implementação gradativa deste processo - fora e dentro da escola - , mas tal expectativa não se confirmou plenamente.

Em 1988, na Conferência de Adelaide, realizada na Austrália, são consideradas como prioritárias para a promoção de políticas públicas saudáveis, os seguintes campos de atuação: apoio à saúde da mulher, alimentação e nutrição, prevenção anti-tabaco e anti-álcool e ambientes saudáveis. Como se verifica, ainda não se registra nenhuma referência mais explícita à escola ou às estratégias para o seu engajamento nos campos considerados prioritários. ${ }^{7}$

Em 1991, a Conferência de Sundsvall considera que o conceito de "ambiente saudável" abrange os aspectos físico e social, referindo-se "aos espaços nos quais as pessoas vivem: a comunidade, suas casas, seu trabalho e lazer. São também referidas as "estruturas que determinam o acesso aos recursos para viver e as oportunidades para ter maior poder de decisão" (MINISTÉRIODA SAÚDE 1997).

Ainda que a "escola" não tenha sido incluida como um "espaço onde as pessoas vivem", já há uma referência mais direta ao papel desta instituição, caso se considere que ela também é determinante do "acesso aos recursos para viver e as oportunidades para ter maior poder de decisão". Entre as estratégias para assegurar a promoção de saúde, a Conferência de Sundsvall incluiu a de "capacitar comunidades e indivíduos a

\footnotetext{
${ }^{6}$ Ainda que se tenha reconhecido que a promoção da saúde está estreitamente relacionada ao processo de capacitação da comunidade, pouco se avançou quanto à natureza deste processo, muito menos sobre as tais "habilidades individuais" a serem desenvolvidas nos cidadãos. Da mesma maneira, embora a educaçăo tenha sido considerada como pré-requisito para a saúde ( aliás, seria indefensável uma posiçăo diferente desta), é tratada apenas como fim, uma vez que nada se disse a respeito do seu processo.

7 Observe-se que, de 1986 a 1988, o que se caracterizava inicialmente como "campos de ação da promoção da saúde", passou a incorporar basicamente "temas": alimentação e nutrição, prevenção do tabaco e do álcool.
} 
ganharem maior controle sobre sua saúde e ambiente, através da educação e maior participação nos processos de tomada de decisão". ${ }^{8}$

Em 1992, na Conferência de Bogotá, é reconhecida a especificidade da promoção de saúde na América Latina, enfatizando-se a necessária relação entre "saúde" e "desenvolvimento". Com efeito, afirma-se que "a promoção de saúde na América Latina busca a criação de condições que garantam o bem estar geral como propósito fundamental do desenvolvimento, assumindo a relação de mútua determinação entre saúde e desenvolvimento". Mais uma vez, nenhuma referência mais explícita à educação formal, ainda que uma das estratégias apontadas para a promoção de saúde tenha sido "impulsionar a cultura da saúde, modificando valores, crenças, atitudes e relações que permitam atingir tanto a produção como o usufruto de bens e oportunidades para facilitar opções saudáveis"(MINISTÉRIO DA SAÚDE 1997).

Finalmente, a Declaração de Jacarta, de 1997, considera que "a promoção de saúde, mediante investimentos e ações, atua sobre os determinantes da saúde para criar o maior beneficio para os povos, para contribuir de maneira significativa para a redução das iniqüidades em questão de saúde, para assegurar os direitos humanos e para a formação do capital social" (MINISTÉRIO DA SAÚDE 1997). Aos pré-requisitos para a saúde, relacionados na Carta de Ottawa, são acrescentados segurança social, relações sociais, direito de voz das mulheres e respeito aos direitos humanos. Por sua vez, o prérequisito "educação" é substituido por "instrução".

Mantida a devida reserva, pode-se considerar que, em termos de referenciais teóricos, não são pródigas as contribuições dessas Conferências para a definição do que se esperaria da educação formal segundo a ótica da promoção de saúde. Da mesma maneira, pode-se inferir que a histórica dificuldade de articulação entre os diversos setores das políticas públicas não chega a se render de pronto diante de um paradigma mais holístico de vida e de saúde.

\footnotetext{
${ }^{8}$ Além desta, são apontadas três outras estratégias para a promoção de saúde: a realização de ações comunitárias, particularmente grupos organizados de mulheres, a construção de alianças para a saúde e ambientes favoráveis e o diagnóstico ( e "medida") dos interesses conflitantes da sociedade. Note-se que, a despeito da referência específica à educação, ainda não há nenhuma menção à educação formal ou à atuaçăo especifica da escola.
} 
Poder-se-ia, por conta disso, considerar que o movimento da promoção de saúde, orientado por um paradigma holístico de saúde, nega a Educação em saúde? Com certeza não, e este posicionamento já foi aqui explicitado. A bem da verdade, não há nenhuma contradição teórica entre os pressupostos da Educação em saúde e os da promoção da saúde, aliás, conforme se pode verificar ao longo deste documento. É óbvio que esta não é a situação quando se tem em mente um protótipo de Educação em saúde que se deixa aprisionar nos limites da instituição escolar, ou se permite reduzir a ações meramente informativas que remetem a responsabilidade pela manutenção da saúde exclusivamente à esfera dos comportamentos individuais - e este não é o panorama teórico postulado pelos que batalham para que a escola faça Educação em saúde, segundo o que se pode depreender da leitura do próximo item.

\section{B. Saúde escolar, promoção de saúde e "escolas promotoras de saúde"}

A busca das origens da Saúde Escolar indica que esta área esteve significativamente impregnada de concepções herdadas do sanitarismo, da polícia médica e da puericultura. Com efeito, o interesse na atuação da escola na área da saúde data do século XVII, coincidindo com a realização de ações de fiscalização das condições de saúde dos alunos e da "salubridade" das escolas e a divulgação de hábitos destinados à manutenção da saúde individual. No final do século XIX, quando Alemanha e Estados Unidos institucionalizaram a higiene escolar, associaram-na à missão de redimir "a pobreza através da educação sobre os novos hábitos de higiene que, melhorando os corpos pela ginástica, pela boa alimentação, pela redução da estafa provocada pelos maus hábitos de estudo e de posicionamento nas carteiras escolares, possibilitaria uma maior aptidão para o trabalho e para as obrigações impostas pela cidadania" (SILVEIRA 1994).

No decorrer do tempo, a Educação em saúde brasileira sofreu a influência das várias correntes de pensamento pedagógico que contaminaram o cenário educacional. $\mathrm{Na}$ década de 20, por exemplo, o Movimento da Escola Nova - que prioritariamente defendeu a democratização do ensino fundamental - passou a encarar a infância como um estágio importante do amadurecimento humano e, por extensão, a considerar a 
escola como a instituição responsável pela formação do educando para a vida social (SILVEIRA 1994) Além disso, o movimento da Escola Nova assimilou o referencial de que a transformação da sociedade poderia decorrer de ações da escola na área da saúde.

$\mathrm{Na}$ história mais recente, a partir da década de 70, as discussões mais amplas da sociedade em torno da "promoção de saúde" invadiram o cenário da educação e, conforme se pode constatar, embora as Conferências Mundiais de Saúde pouco tenham se pronunciado a respeito do papel da escola na promoção da saúde, inúmeros grupos dedicaram-se a esta reflexão. Com efeito, o tema recorrente de inúmeras reuniões de educadores foi sempre a definição de estratégias que permitam às escolas criar as circunstâncias necessárias para iniciar o processo social e político gerador de mudanças necessárias à melhoria da qualidade de vida e saúde da população. Tratava-se, portanto, de resolver um histórico dilema: envolver efetivamente a escola na promoção de saúde, sem cair, mais uma vez, no engodo de considerá-la como a redentora das condições sócio-econômico-culturais que determinam o nível de qualidade de vida de uma comunidade.

Observe-se, portanto, que o conceito de "promoção de saúde" começa a se fortalecer quando a crença nas abordagens da Educação em saúde centradas exclusivamente no indivíduo são abaladas. Não se trata, portanto, de um outro movimento, mas sim da expressão de uma mudança paradigmática quanto à maneira de encarar - e de melhorar - a situação de saúde de uma sociedade.

No que se refere à concepção de saúde que o embasa, é óbvio que este movimento enfatiza o caráter múltiplo e histórico de sua determinação: a saúde tem determinantes sociais, econômicos e ambientais. A conjugação entre estes fatores, por sua vez, pode agregar considerável potencial de transformação de uma dada situação de saúde, muito mais do que se poderia esperar de qualquer um deles, isoladamente.

Trata-se, portanto, de instaurar um movimento integral pela formação da cidadania ou seja, que os cidadãos se fortaleçam ${ }^{9}$ e se mobilizem para obter melhores condições de vida, num autêntico "processo educacional de mudança" que resulte em

\footnotetext{
${ }^{9}$ Este movimento, porque supoe a atuaçåo decisiva dos cidadãos na conquista de melhores condições de vida e saúde, é frontalmente contrário ao paternalismo e a qualquer ação que desrespeite o principio do respeito à autonomia individual.
} 
níveis crescentes de organização popular, em políticas saudáveis e legislação que as regulamente. Nesta perspectiva, a conquista definitiva de melhores niveis de saúde e de qualidade de vida é tarefa que não pode se circunscrever à esfera da atuação escolar, a despeito da especificidade da instituição escolar. Portanto, a escola é mais uma das instâncias no processo gradativo de formação da cidadania - e não há como avançar nesta direção sem que se estabeleça a necessária sinergia entre escola e movimentos populares. ${ }^{10}$

Tal posicionamento não implica a desvalorização nem dos programas educativos escolares, nem dos programas desenvolvidos pelos sistemas de saúde: o desafio é o de articular estes dois níveis legítimos de promoção da saúde e assegurar que a perspectiva de abordagem das questões ultrapasse os limites da saúde individual, incorporando a visão ecológica de saúde.

De fato, quando se reconhece que a saúde da infância e da juventude é um valor fundamental a ser promovido em todas as sociedades e paises e se toma como referência o caráter abrangente da promoção de saúde, até por uma questão de boa lógica, é indispensável assegurar a colaboração entre jovens, adolescentes, famílias, escolas, serviços de saúde, organizações não governamentais, instituições oficiais, indispensável para conferir um enfoque integral à Educação em saúde fora e dentro da escola.

Conforme já se reconheceu, inúmeros esforços têm sido canalizados nesta direção. Assim, em 1986, a Organização Mundial de Saúde (OMS), a Organização Panamericana de Saúde (OPAS) e o Fundo das Nações Unidas para a Infância das Nações Unidas (UNICEF) publicam documento no qual são relatados os resultados de uma pesquisa internacional sobre a complexidade da aprendizagem na área da saúde - fora e dentro da escola - , o diagnóstico da Educação em saúde no conjunto dos países investigados e as propostas de estratégias para fortalecê-la nos sistemas educativos (OPAS e OMS 1995).

\footnotetext{
${ }^{10}$ Para alguns teóricos, a emergência deste entendimento da necessária sinergia entre os esforços da escola e a organização da sociedade para lutar por melhores condiçðes de vida e de saúde contribuiu para esvaziar as iniciativas de assegurar a Educaçå em saúde no interior das escolas. Ao que tudo indica, esta percepção é equivocada e será oportunamente retomada neste texto.
} 
Sete anos depois desta iniciativa, realiza-se na Costa Rica, uma reunião entre técnicos de doze países latino-americanos que vinham implementando projetos de Educação em saúde em escolas, com o objetivo de trocar experiências e propor estratégias de articulação entre a Saúde e a Educação. Pretendia-se, desta maneira, reunir elementos para apoiar o desenvolvimento de experiências calcadas num enfoque integral e compreensivo de Educação em saúde na escola.

Segundo este enfoque, a atuação das escolas deveria cobrir três diferentes componentes, intimamente relacionados:

- a oferta de serviços de saúde na escola;"

- a instalação de ambientes escolares saudáveis e, finalmente;

- a oferta de Educação em saúde.

Em relação a este último componente - a Educação em saúde - a Organização Pan-americana de Saúde indica que se deva nortear pelas seguintes diretrizes:

- abordar a saúde em termos globais, segundo a ótica de inter-relação entre os seus fatores individuais, ambientais, sócio-econômicos e coletivos;

- esgotar todas as oportunidades educativas - formais e informais - para promover, melhorar, manter e recuperar a saúde;

- analisar criticamente as diferentes mensagens de saúde que influenciam as crianças e os jovens;

- comprometer-se com a conscientização de crianças e jovens para atuarem de maneira a favorecer a manutenção e a promoção da saúde integral e coletiva;

- construir continuadamente uma convivência solidária em prol da vida e dos direitos humanos.

Desta forma, estabelece-se um padrão bastante preciso sobre a atuação de uma escola comprometida com a promoção da saúde. Para designar as escolas que.

\footnotetext{
"Esta posição não é ainda consensual no Brasil, pelo menos no atual estágio da saúde pública brasileira e dos niveis de cobertura dos serviços de saúde. Admite-se, sim. que a escola deve estabelecer vinculos efetivos com os serviços de saude instalados, universalizando o atendimento a todos os alunos, sem que se dupliquem recursos humanos e materiais. Aliás, no Estado de Sào Paulo a rede pública de escolas já contou com serviço médico e odontológico e as avaliaçòes da efetividade desta sistemática nào foram das mais positivas.
} 
progressivamente, passam a atuar segundo estes critérios, cunha-se a expressão "escolas promotoras de saúde". ${ }^{12}$

Segundo a Organização Pan-americana de Saúde (OPAS), caracteriza-se como "escola promotora de saúde" aquela que atua concomitantemente nas três áreas anteriormente definidas: ambiente saudável, oferta de serviços de saúde e Educação em saúde. $^{13}$

Este referencial teórico tem recebido a adesão de inúmeros sistemas educacionais, em diferentes países, inspirando a elaboração de diretrizes para que as escolas possam incorporar, ao seu cotidiano, ações efetivas nestes três campos de atuação. No caso do Brasil, o discurso formal igualmente assimilou este paradigma, segundo as indicações do próximo item.

\section{A promoção de saúde na perspectiva dos novos parâmetros curriculares nacionais para o ensino fundamental}

Até dezembro de 1996, o Ensino Fundamental brasileiro esteve estruturado nos termos da Lei Federal $n^{\circ}$ 5692, de 11 de agosto de 1971. Com duração de oito anos, o Ensino Fundamental representava o nível de escolarização obrigatória no país, tendo como objetivo geral proporcionar aos educandos a formação necessária ao desenvolvimento de suas potencialidades como elemento de auto-realização, preparação para o trabalho e para o exercício consciente da cidadania. ${ }^{14}$

Em relação ao curriculo escolar, esta lei fixou um conjunto de disciplinas obrigatórias em âmbito nacional para o Ensino Fundamental e o Ensino Médio, designando-o de "núcleo comum"; a este conjunto de disciplinas, cada Estado deveria acrescentar uma "Parte Diversificada", composta por disciplinas e/ou atividades que permitissem contemplar as peculiaridades locais, a especificidade dos planos das escolas

\footnotetext{
${ }^{12}$ Caracteriza-se como "escola promotora de saúde" aquela que se coloca a serviço da promoção da saúde, promoção esta entendida segundo a amplitude expressa neste texto.

${ }^{13} \mathrm{O}$ conceito de escola promotora de saúde está mais amplamente discutido no próximo item, quando se trata dos Parâmetros Curriculares Nacionais.

${ }^{14}$ Segundo dados do Instituto Nacional de Estudos e Pesquisas do Ministério da Educação, no periodo de 1.991 a 1.998, a taxa liquida de escolarização da população de 7 a 14 anos saltou de $86 \%$ para $95 \%$ (no Estado de São Paulo, em 1998, esta taxa foi de $98,2 \%$ ). Embora não se possa negar que a situação educacional do pais tenha avançado sensivelmente neste periodo. fica evidente que a obrigatoriedade prevista na lei ainda não foi de todo cumprida.
} 
e as diferenças individuais dos alunos. Aos Estados caberia a formulação de propostas curriculares que definissem as diretrizes gerais para as escolas estaduais, municipais e particulares de cada sistema de ensino. ${ }^{15}$

No início da década de 90 , num processo coordenado pelo então Ministério da Educação, é elaborado o Plano Decenal de Educação para Todos (1993-2003), em resposta aos compromissos assumidos pelo Brasil na Conferência Mundial de Educação para Todos, em Jomtien, na Tailândia, bem como pelo fato do país ter sido signatário da Declaração de Nova Delhi. ${ }^{16}$ Em consonância com o estabelecido na Constituição Federal de 1988, o referido Plano Decenal afirma a necessidade e a obrigação de o Estado elaborar "parâmetros claros no campo curricular, capazes de orientar as ações educativas do ensino obrigatório, de forma a adequá-lo aos ideais democráticos e à busca da melhoria da qualidade de ensino nas escolas brasileiras"(MINISTÉRIO DA EDUCAÇÃO 1995a).

A Lei de Diretrizes e Bases da Educação Nacional, aprovada em dezembro de 1996, além de consolidar e ampliar o dever do poder público para com a educação em geral e, em particular, para com o Ensino Fundamental, reforça a necessidade de se propiciar a todos os brasileiros uma "formação básica comum"17, o que pressupõe a formulação de diretrizes que possam nortear a elaboração dos currículos escolares. ${ }^{18}$

Assim, a partir da consulta às propostas curriculares dos Estados e Municipios que delas dispunham, o Ministério da Educação formulou uma proposta inicial dos "Parâmetros Curriculares Nacionais", discutida nos anos de 1995 e 1996, em inúmeros

\footnotetext{
${ }^{15}$ Ainda que a Lei Federal no. 5692 datasse de 1971, dez anos mais tarde os Estados haviam elaborado muito mais "listas de conteúdos programáticos" do que, propriamente, "propostas curriculares". O processo de elaboração destas Propostas só veio a acontecer efetivamente nos primeiros anos da década de 80, sendo São Paulo o Estado pioneiro neste processo. No caso da saúde, as indicações curriculares para sua abordagem nas escolas integravam, no Ensino Fundamental, a Proposta Curricular para o Ensino de Ciências e, no Ensino Médio, a Proposta Curricular para o Ensino de Biologia.

${ }^{16} \mathrm{Da}$ Conferência de Jomtien, assim como da Declaração de Nova Delhi, assinada por nove países de maior contingente populacional do mundo, resultaram posiçðes consensuais quanto à urgência de garantir a satisfaçăo das necessidades básicas de aprendizagem para todos, universalizando-se a Educação Fundamental e ampliando-se as oportunidades de aprendizagem para crianças, jovens e adultos.

${ }^{17}$ Ressalte-se que, enquanto a legislação anterior exigia uma escolarização obrigatória de 8 anos, a nova legislaçăo sugere que esta obrigatoriedade deva se estender, progressivamente, até 11 anos. Com efeito, a nova Constituição fala da obrigatoriedade da "Educação Básica", nivel de ensino que, agora, compreende - Ensino Fundamental (com duração de 8 anos) e o Ensino Médio (com três anos de duração).

${ }^{18}$ Segundo o artigo $9^{\circ}$, inciso IV, tais diretrizes curriculares devem ser de competência da União.
} 
encontros. ${ }^{19}$ Tais parâmetros incluem diretrizes curriculares para as áreas de Lingua Portuguesa, Matemática, Ciências Naturais, História, Geografia, Arte, Educação Física e Língua Estrangeira, encaradas tradicionalmente como os espaços para o tratamento dos conteúdos a serem assegurados a todos os brasileiros. Além disso, coerente com a crença de que "há outros temas diretamente relacionados com o exercício da cidadania, há questões urgentes que devem necessariamente ser tratadas, como a violência, a saúde, $o$ uso dos recursos naturais, os preconceitos, que não têm sido diretamente contemplados por essas áreas" (MINISTÉRIODAEDUCAÇÃO 1997 e), foram também elaboradas diretrizes curriculares para os chamados "temas transversais": Ética, Saúde, Meio Ambiente, Trabalho e Consumo, Orientação Sexual e Pluralidade Cultural. ${ }^{20}$

Para assegurar a abordagem de toda esta gama de conhecimentos ${ }^{21}$ e as diferentes problemáticas sociais, a estratégia sugerida pelo Ministério foi a de manter a estrutura curricular já vigente nos sistemas educacionais: o currículo é estruturado por disciplinas ou componentes curriculares, a despeito de que seja uma ou mais as professoras responsáveis pelo conjunto dessas disciplinas. ${ }^{22}$ Cada professor deve se responsabilizar pelo tratamento dos temas transversais em sua área de atuação - as disciplinas ou o conjunto delas - , segundo a sua pertinência e especificidade.

Assim, segundo o discurso oficial, os temas transversais cumprem o papel de facilitar que a escola se caracterize não apenas como um espaço de reprodução, mas também como espaço de transformação, na medida que passa a tratar de questões relacionadas diretamente ao exercício da cidadania, conforme já referido anteriormente. Segundo o documento introdutório dos "Parâmetros Curriculares Nacionais", é

\footnotetext{
${ }^{19}$ Segundo o Ministério da Educação, a proposta preliminar foi discutida por docentes de universidades públicas e particulares, técnicos de Secretarias Estaduais e Municipais de educaçăo, representantes de sindicatos e entidades ligadas ao magistério; a despeito disso, sào recorrentes as criticas de muitos segmentos educacionais de que apenas uma minoria participou destas discussões.

${ }_{20}$ Observe-se que nào se trata de uma estratégia curricular inédita. A reforma curricular espanhola. iniciada na década de 80 , adotou estratégia semelhante no que se refere à organização dos conteúdos. embora as soluçðes propostas pelos dois paises para a operacionalização dos curriculos propostos tenham sido diferenciadas.

${ }^{21}$ Note-se que os "Parâmetros Curriculares Nacionais" para o Ensino Fundamental lidam com uma noção expandida de "conhecimento", categoria esta que engloba conteúdos, procedimentos e atitudes.

${ }^{22}$ De maneira geral, até a $4^{\circ}$ série ( ou até a 6 série. em alguns casos) do Ensino Fundamental, todas as disciplinas são ministradas por um único professor polivalente; desta(s) série(s) em diante, há um professor especialista para cada uma das disciplinas previstas, inclusive nos novos "Parâmetros Curriculares Nacionais".
} 
necessário disseminar - à comunidade escolar e à sociedade, em geral - a compreensão de que "as práticas pedagógicas são sociais e politicas e de que não se trata de educar para a democracia ou educar para o futuro. Na ação mesma da educação, educadores e educandos estabelecem uma determinada relação com o trabalho que fazem ( ensinar e aprender) e a natureza dessa relação pode conter (em maior ou menor medida) os princípios democráticos"(MINISTÉRIODA EDUCAÇÃO 1997a).

Depreende-se daí que a contribuição da escola é a de desenvolver um projeto de educação comprometida com o desenvolvimento de capacidades que permitam intervir na realidade para transformá-la; por conseguinte, a tarefa educativa é interpretada como uma intervenção na realidade no momento presente, o que exige que a comunidade escolar se posicione continuamente em relação às questões sociais. ${ }^{23}$

A delimitação dos limites e perspectivas propostos pelo Ministério da Educação para esta intervenção exige a análise cuidadosa dos documentos referentes às diferentes áreas e temas transversais; no entanto, no âmbito deste estudo interessam, particularmente, os documentos referentes ao tema transversal "Saúde". Afinal, qual é o posicionamento assumido pelo Ministério da Educação quanto ao papel da escola nesta área: ensinar saúde ou "promover" saúde? Como, no que se refere especificamente à saúde, a ação escolar deveria estar contribuindo para a pretendida "transformação da realidade"? Como o projeto pedagógico de cada escola deverá trabalhar a área da saúde na perspectiva de comprometimento com a construção da cidadania brasileira?

Os parâmetros curriculares referentes ao tema "saúde" optam por um paradigma integral de saúde, explicitando que o fenômeno saúde-doença emerge das próprias formas de organização da sociedade; priorizando, assim, o entendimento de saúde como um valor coletivo, de determinação social. Destacam, ainda, a necessidade de "romper com dois enfoques: o que coloca a saúde individual como determinada unicamente pela realidade social ou pela ação do poder público, e o que coloca todo o peso no individuo, em sua herança genética e empenho pessoal"(MINISIÉRIODAEDUCAÇÃO 1997 f).

\footnotetext{
${ }^{23}$ Nåo há dúvida de que esta concepção educacional expressa nos "Parâmetros Curriculares Nacionais" é absolutamente coerente com as premissas da promoção da saúde. Nos dois casos, postula-se que a transformação seja um processo traçado e trilhado pelas pessoas, individual e coletivamente.
} 
Ao optar por uma visão integral de saúde, o documento afirma que "falar de saúde (...) implica levar em conta a qualidade da água que se consome e do ar que se respira, as condições de fabricação e uso de equipamentos nucleares ou bélicos, $o$ consumismo desenfreado e a miséria, a degradação social ou a desnutrição, os estilos de vida pessoais e as formas de inserção das diferentes parcelas da população no mundo do trabalho. Implica, ainda, consideração dos aspectos éticos relacionados ao direito à vida e à saúde, aos direitos e deveres, às ações e omissões de indivíduos e grupos sociais, dos serviços privados e do poder público" (MINISTÉRIODAEDUCAÇÃO1997e).

Refere-se, ainda, ao conceito de "cidade saudável" ${ }^{24}$, afirmando que a promoção da saúde se "faz quando são asseguradas as condições para a vida digna dos cidadãos; se faz, especificamente, através da educação, da adoção de estilos de vida saudáveis, do desenvolvimento de aptidões e capacidades individuais, da produção de um ambiente saudável, da eficácia da sociedade na garantia da implantação de políticas públicas voltadas para a qualidade da vida e dos serviços de saúde"(MINISIÉRIO DA EDUCAÇÃO $1997 \mathrm{e})$.

Quanto ao papel da educação e da escola, a despeito de considerar que a escola é um espaço privilegiado para a implementação da Educação para a Saúde, o documento considera que o papel da educação não é o de substituir as mudanças estruturais necessárias para a garantia da qualidade de vida e saúde, mas pode contribuir decisivamente para sua efetivação. ${ }^{25}$

Finalmente, aconselha a aproximação gradativa das escolas ao padrão definido pela Organização Mundial da Saúde, considerando que "as escolas que fazem diferença e contribuem para a promoção da saúde são aquelas que:

- têm uma visão ampla de todos os aspectos da escola, provendo um ambiente saudável e que favorece a aprendizagem, não só nas salas de aula, mas também nas áreas destinadas ao recreio, nos banheiros, nos espaços em que se prepara e é servida a merenda, enfim, em todo o prédio escolar;

\footnotetext{
${ }^{24}$ Este conceito, originado no Canadá na década de 80, vem inspirando muitos projetos de saúde, desde que foi incorporado pela Organização Mundial de Saúde.

${ }^{25} \mathrm{O}$ documento enfatiza que há uma estreita ligaçăo entre o acesso à educação e melhores níveis de bem estar. Cita, a titulo de comprovação, que "as taxas de mortalidade infantil são inversamente proporcionais ao número de anos de escolaridade da màe em termos de ensino básico, em diferentes paises e realidates".
} 
- concedem importância à estética do entorno físico da escola, assim como ao efeito psicológico direto que ele tem sobre professores e alunos;

- estão fundamentadas num modelo de saúde que inclui a interação dos aspectos fisicos, psiquicos, sócio-culturais e ambientais;

- promovem a participação ativa de alunos e alunas;

- reconhecem que muitas habilidades e processos básicos são comuns a todos os temas de saúde e que estes devem ser necessariamente incluídos nas diferentes áreas curriculares;

- entendem que o desenvolvimento da auto-estima e da autonomia pessoal são fundamentais para a promoção da saúde;

- valorizam a promoção da saúde para todos os que nela estudam e trabalham;

- têm uma visão ampla dos serviços de saúde voltados para o escolar;

- reforçam o desenvolvimento de estilos saudáveis de vida e oferecem opções viáveis e atraentes para a prática de ações que promovam a saúde.

- favorecem a participação ativa dos educadores na elaboração do projeto pedagógico da Educação para a saúde;

- buscam estabelecer inter-relações na elaboração do projeto escolar"(MINISTÉRIODAEDUCAÇÃO $1997 \mathrm{e})$.

Verifica-se, portanto, que os parâmetros curriculares nacionais assumiram basicamente os referenciais teóricos que foram estabelecidos pelas Organizações Mundial e Pan-americana de Saúde. No âmbito desta pesquisa, tais parâmetros inspiraram não apenas o tipo de pré-roteiro utilizado nas entrevistas da equipe escolar, como também forneceram os referenciais para que se pudesse avaliar o grau de aproximação entre as práticas cotidianas da escola investigada e o que se chama aqui de "escola promotora de saúde". Em sintese, estes referenciais teóricos representam o eixo central desta investigação, aliás, como já se afirmou aqui anteriormente. Com efeito, as representações sociais da equipe escolar foram estimuladas e, posteriormente, analisadas, sob a ótica destes referenciais.

Este referencial teórico - suficiente para permitir que o olhar desta pesquisa fosse dirigido para as representações sociais referentes aos aspectos que realmente têm a ver 
com promoção de saúde - necessita de uma articulação também criteriosa com um universo de conhecimentos sobre o que esta pesquisa se dispôs a olhar, ou seja, as representações sociais e, ainda, o que se considera hoje como uma escola pública de boa qualidade.

\section{As representações sociais}

O conceito da representação social (ou coletiva) nasceu na sociologia e na antropologia, com Durkheim e Lévi-Bruhl. Com Serge Moscovici, este conceito foi resgatado e introduzido na psicologia social, especialmente no seu estudo “A psicanálise, sua imagem e seu público", publicado em Paris na década de 70, constituindo, na atualidade, em referencial obrigatório nas pesquisas de orientação qualitativa ou, ainda, no interior das Ciências Sociais.

A despeito das divergências verificadas acerca deste conceito, há relativo consenso de que as representações sociais são uma forma de conhecimento, socialmente elaborado e partilhado, conhecimento este que, ao mesmo tempo, expressa uma visão prática de uma determinada realidade comum a um conjunto social, num determinado momento, e concorre para a construção desta mesma realidade.

Desta maneira, as representações sociais são sempre "imagens construídas do real"(MINAYO 1995), que se expressam através de palavras, sentimentos e condutas. Tais imagens estão intimamente relacionadas com o lugar social de onde os atores as constróem - e, neste caso, vale a regra de que o observado depende do observador, ou seja, as imagens do real são marcadas pelo "habitus", pelo lugar de onde se fala, conservando a marca da estrutura social. Logo, a sua análise será tanto mais acurada quando mais se conseguir uma boa compreensão das estruturas e dos comportamentos sociais.

Estas construções acerca do real expressam-se sempre sob uma forma de linguagem, considerada aqui como uma forma de conhecimento e de interação social.

Assim, por exemplo, quando uma professora de uma escola manifesta-se a respeito do projeto pedagógico de sua escola e do seu projeto de ensino, em particular. está exercitando a sua competência de relatar a "realidade" de sua escola - e a sua 
própria -, conforme a apreende no contato com seus pares. Ainda que este relato possa representar apenas um fragmento dessa realidade, apresentando pontos divergentes de outros eventuais relatos de profissionais que atuam com ela nesta escola, ele é sempre um referencial da realidade vivenciada pela referida professora. E isto acontece porque "a realidade vivida é também representada e através dela os atores sociais se movem, constróem sua vida e explicam-na mediante seu toque de conhecimentos"(MINAYO 1994).

A despeito desta reconhecida correspondência entre representações sociais e realidade, estas imagens merecem cuidadosa análise, uma vez que expressam as contradições e os conflitos presentes na situação em que foram elaboradas. Um outro aspecto é o de que não são necessariamente conscientes - e uma pessoa pode ter-se imbuído de uma determinada visão a respeito de certo fenômeno social, sem que se tenha dado conta disso.

Em sintese, porque as representações sociais são, ao mesmo tempo retratos da realidade - contraditórios, porém verdadeiros - representam não apenas um bom referencial para a análise do social ( no caso, o projeto de implementação do projeto pedagógico da escola pública envolvida neste estudo), como também para a ação pedagógico-política de transformação, uma vez que retratam a realidade, segundo determinado segmento da sociedade (no caso, os elementos da equipe escolar que foram envolvidos neste estudo). Por estas razões, o presente estudo utilizar-se-á das representações sociais de inúmeros atores para desvendar a realidade do processo de construção do projeto de uma escola saudável, na crença que esta compreensão é urgente e necessária, especialmente porque a consolidação da cidadania brasileira passa, também, pela necessidade de que as escolas se integrem ao movimento crescente de promoção de saúde, segundo o entendimento aqui explicitado.

A tarefa não é fácil, até porque, a despeito do grande avanço na área das pesquisas escolares, a realidade cotidiana dos processos e contextos de ensino e aprendizagem está longe de ser perfeitamente decodificada. Dai a necessidade de ampliar os referenciais relativos às representações sociais, em especial no que se refere à subjetividade própria do currículo e do espaço escolar. 


\section{E. Currículo, espaço e subjetividade}

Num exercício de sintese, poder-se-ia dizer que o referencial básico desta investigação é tomar a linguagem - $\mathrm{e}$ as vivências e representações individuais $\mathrm{e}$ interpessoais por ela explicitadas - para buscar a compreensão do social. No entanto, há outras questões que, à semelhança da linguagem, constituem-se em peças chave para aperfeiçoar esta mesma compreensão - as questões do espaço e do tempo da escola. Afinal, como desvendar a natureza da instituição escolar, se não se toma o espaço escolar em sua perspectiva histórica?

Qualquer atividade humana define-se num espaço e num tempo determinados - o ensinar e o aprender não fogem a esta regra. Desta maneira, "o espaço e o tempo são elementos constitutivos da ação educativa" (FRAGO 1998). Com efeito, a ocupação do espaço escolar é sempre uma construção - e escolas que funcionam em prédios construídos rigorosamente a partir de uma mesma planta arquitetônica, podem apresentar diferenças tão grandes entre si que colocam em dúvida se, de fato, manteve-se fidelidade a um único padrão de construção. Do prédio escolar - estrutura física - ao lugar escola, há, pois, no dizer de FRAGO, um autêntico processo de construção coletiva, um verdadeiro salto qualitativo.

Dai se depreende que a escola, enquanto instituição, ocupa um espaço e um lugar - independentemente da qualidade ou natureza do tal "salto qualitativo". O prédio escolar - projetado ou não com a finalidade de ser uma escola - é um espaço dado para ser ocupado e utilizado. E na medida que esta investigação se propõe a lidar com as representações sociais da equipe escolar relativas à sua atuação na área da promoção da saúde - temática que possui um componente relativo ao ambiente físico da escola - é fundamental que se desenvolva uma certa sensibilidade quanto às maneiras pelas quais se dá a apropriação individual e coletiva do espaço, inclusive do espaço escolar.

Ao que tudo indica, o fato de se tomar posse do espaço vivido - individual e coletivamente - tem um papel decisivo na conformação deste individuo e de seus grupos e é óbvio que a percepção que estes indivíduos ou grupos têm acerca do espaço conquistado é basicamente subjetiva. Frago afirma, aliás, com muita tranqüilidade, que, 
"em certo sentido, o espaço objetivo - para denominá-lo de alguma maneira - não existe. E se existe, não conta - salvo como possibilidade e como limite"(FRAGO 1998).

Segundo este raciocínio, chega-se à constatação que o espaço jamais é neutro: o espaço "comunica, mostra a quem sabe ler, o emprego que o ser humano faz dele". E o tipo de emprego que se faz de um determinado espaço é sempre produto cultural específico, que diz respeito "não apenas às relações interpessoais - distâncias, território pessoal, contatos, comunicação, conflito de poder - , mas também à liturgia e ritos sociais, à simbologia da disposição dos objetos e dos corpos - localização e posturas - à sua hierarquia e relações". ${ }^{26}$

Por fim, é fundamental que se tenha clareza que o espaço escolar é um elemento cultural e pedagógico - não apenas porque suas estruturas podem induzir inúmeros e distintos condicionamentos - mas também pelo papel de simbolização que desempenha na vida social.

Dada a natureza desta investigação - que não se propõe a fazer historiografia da escola - estas pinceladas a respeito da subjetividade inerente ao espaço escolar são suficientes para, de início, subsidiar as discussões sobre os discursos da equipe escolar, em especial, no que se refere aos aspectos fisicos e da história da escola, eventualmente neles incorporados.

Fica ainda a questão: em que medida a apropriação que a equipe escolar e a comunidade fazem do espaço escolar assegura à escola as condições necessárias para que a escola seja uma boa escola? Ainda: qual a concepção que se tem a respeito do que seja uma boa escola?

\section{E. Afinal, o que é uma escola de boa qualidade?}

Embora haja uma certa controvérsia sobre o que significa uma escola de boa qualidade, a literatura mais recente indica que, no caso dos sistemas públicos de ensino, persegue-se uma transformação fundamental: desvencilhar-se da cultura do fracasso, incorporando a cultura do sucesso. Isto significa que se busca romper com a concepção

\footnotetext{
${ }^{26}$ Segundo FRAGO, o estudo da dimensão social do espaço tem em Edward T. Hall . na obra La dimensión oculta (México, Fundo de Cultura Económica, 1972), o seu texto clássico.
} 
de que escolas boas são aquelas que reprovam, em favor da concepção de que escolas boas são aquelas que asseguram a permanência de todos os alunos e alunas na escola, estruturando-se de forma a que possam receber educação de qualidade. ${ }^{27}$

A despeito de impropriedade de se aprofundar demasiadamente esta discussão ao menos no espaço deste trabalho -, é indispensável que se levantem alguns fatores que estão presentes nas escolas que conseguem caminhar na direção da cultura do sucesso escolar, tomando como parâmetros os resultados das pesquisas que se vêm realizando junto aos diferentes sistemas educacionais, em particular, a pesquisa realizada pela Fundação Carlos Chagas, entre 1992 e 1994, na rede estadual de ensino paulista. ${ }^{28}$ Uma vez que a presente investigação tem como foco de estudo uma escola da rede pública, convém enfatizar muito mais as caracteristicas das escolas cujos alunos e alunas conseguem melhor desempenho escolar do que propriamente qualificar o nível de desempenho por eles alcançado por eles no decorrer do estudo realizado pela Fundação Carlos Chagas.

Os resultados desse estudo revelaram o forte peso da atuação de professores, diretores e professores coordenadores sobre o desempenho dos alunos e na sua capacidade de manejar de forma competente o tempo e os recursos pedagógicos disponíveis. ${ }^{29} \mathrm{Em}$ sintese, as escolas cujos alunos e alunas conseguiram obter os melhores niveis de desempenho foram aquelas cuja equipe escolar conhece o Plano da

\footnotetext{
${ }^{27}$ Esta concepçåo tem merecido inúmeras críticas, em especial, das associaçðes de professores, sob a alegação de que a cultura do sucesso escolar tem contribuído para a promoção de alunos que não têm o mínimo padrăo de desempenho escolar. No entanto, nåo é mais admissivel que a escola ainda se mostre impermeável à concepção de que todos podem aprender e vire as costas à urgència de alterar o foco da ação educativa - não basta apenas ensinar : é necessário que os alunos aprendam. Não se trata de oferecer educação de má qualidade, mas de lançar måo de estratégias que permitam que crianças com diferentes ritmos de aprendizagem possam cursar trajetos diferenciados ao longo de sua vida escolar, resolvendo suas dificuldades de aprendizagem, tão logo elas se expressem. Por outro lado, deve-se ter em conta que, se altos indices de repetência escolar fossem garantia de qualidade de ensino, o pais deveria se distinguir por excelentes niveis de desempenho escolar, situação esta que é bastante distante da que se enfrenta há décadas.

${ }^{28}$ Neste periodo, a Fundação Carlos Chagas realizou pesquisa em escolas da região metropolitana de São Paulo, visando avaliar o impacto da implantação do Projeto "Inovações do Ensino Básico". O estudo comparou o desempenho de alunos de diferentes escolas existentes na rede pública, relacionando as variáveis que contribuíram para melhorar este desempenho

${ }^{29}$ Segundo os resultados desta pesquisa, o nível de renda familiar só influi sobre o aproveitamento escolar quando está associado a maiores oportunidades de acesso aos bens culturais. A despeito de que os alunos provenientes de familias com maior poder aquisitivo tivessem apresentado resultados melhores, a análise longitudinal mostrou que os mais pobres aproveitaram - e muito - o que a escola pode lhes oferecer, apresentando significativos ganhos de aprendizagem em relação ao seu patamar inicial.
} 
Escola, em detalhes: o diagnóstico no qual ele se baseou, os problemas, as prioridades, as estratégias/ações para resolvê-los, as responsabilidades na implementação dessas ações e um cronograma para realização das mesmas.

No que se refere ao diretor, foram apontadas as seguintes características:

- conhece em detalhes o Plano escolar, considerando-o não apenas como uma formalidade, mas como o registro da história e das intenções da escola que se pretende firmar como uma boa escola;

- tem clareza que o essencial de sua atividade é liderar o processo educativo desenvolvido na escola, subordinando suas atividades administrativas e burocráticas à dimensão pedagógica;

- sabe que metas estão sendo atingidas e aquelas onde é preciso investir mais;

- tem mais de cinco anos de experiência na direção de escolas;

Por sua vez, os professores - coordenadores das boas escolas têm sua atuação marcada pelas seguintes características:

- articulam a construção de uma proposta coletiva de trabalho e definem uma linha pedagógica que direciona a atuação dos professores;

- promovem a articulação entre o trabalho nas diferentes séries;

- têm parâmetros claros quanto às propostas curriculares a serem implementadas e utilizam materiais facilitadores desta implementação;

- têm como objetivo prioritário a diminuição dos índices de evasão e repetência e encaminhanos alunos com lacunas de aprendizagem para recuperação;

- desenvolvem, nas Horas de Trabalho Coletivo ${ }^{30}$, atividades orientadas para apoiar o desempenho dos professores em sala de aula;

- investem na ressignificação do planejamento escolar e na necessidade contínua de replanejamento;

- participam das oportunidades de capacitação oferecidas pela Secretaria de Educação.

Mais uma vez, os resultados da pesquisa da Fundação Carlos Chagas ratificam que as mudanças em educação ou acontecem na sala de aula, ou simplesmente não

\footnotetext{
${ }^{30}$ A jornada de trabalho dos professores da rede estadual de São Paulo inclui duas horas semanais, destinadas à realização de atividades coletivas. Esta carga horária é designada "Horas de Trabalho Pedagógico Coletivas", mais comumente rotuladas de "HTPC".
} 
acontecem. Daí a importância da atuação dos professores, pautada em algumas características:

- acreditam que podem ensinar;

- utilizam materiais e recursos didáticos diversificados em suas aulas;

- dominam uma metodologia de trabalho;

- participam de cursos de capacitação e orientação técnica.

Quanto à atmosfera ou clima organizacional destacam-se como escolas de qualidade aquelas:

- que têm um projeto claramente definido;

- cujos professores compartilham a mesma linha de trabalho;

- nas quais o relacionamento é cordial e respeitoso;

- que envolvem ativamente os pais e mães no acompanhamento do projeto da escola.

Ainda segundo o estudo da Fundação Carlos Chagas, há alguns indicadores que podem estar relacionados a uma escola de boa qualidade:

- pais, alunos e pessoas da comunidade são tratados com deferência pelo pessoal da escola, independentemente da função que nela exerçam;

- as instalações são limpas e bem utilizadas;

- as salas de aula e pátios são ambientes de aprendizagem;

- os espaços escolares são ocupados pela comunidade nos finais de semana, para realização de atividades culturais e esportivas, entre outras.

Explicitados os referenciais teóricos que orientaram a realização deste estudo, trata-se, agora, de partir para a análise da metodologia e dos procedimentos metodológicos que presidiram a realização da investigação como um todo. 
CAPÍTULO II Metodologia 


\section{METODOLOGIA}

Neste capítulo, foram explicitados os pressupostos teóricos que referendam esta investigação, muitos dos quais já abordados no capítulo I e, ainda, detalhados os passos e estratégias de sua realização.

\section{A . Pressupostos teóricos}

Desde o início do processo de planejamento desta investigação, tinha-se bastante clareza de que se devesse recorrer à metodologia qualitativa, uma vez que as abordagens qualitativas permitem "incorporar a questão do significado e da intencionalidade como inerentes aos atos, às relações e às estruturas sociais, sendo estas últimas tomadas tanto no seu advento quanto na sua transformação, como construções humanas significativas"(MINAYO 1994).

Em relação ao objeto deste estudo - o processo de implementação de um projeto pedagógico de escola comprometido com a promoção de saúde - acreditava-se que as representações que os diferentes atores têm deste processo são estruturantes de suas práticas na escola e, portanto, permitem desvendar os eixos principais que sustentam tal implementação. Da mesma forma, como tais representações se expressam na fala destes sujeitos - e a fala tem um significado que é direto, literal e explícito - , deu-se voz e fala a profissionais que atuam na escola investigada, buscando levantar sua compreensão a respeito do que seja saúde, educação, das relações entre saúde e educação, de promoção da saúde e as estratégias das quais lançam mão - no âmbito especifico de sua atuação para imprimir ao processo educativo uma tal e declinada direção.

Em sintese, a espinha dorsal deste trabalho é a percepção das profissionais da escola investigada face às situações aí vividas, os significados que atribuem a estas situações, suas motivações, atitudes e valores, expressas em seus depoimentos, enfim, as suas representações acerca da experiência vivenciada na escola. ${ }^{31}$

\footnotetext{
${ }^{31}$ Segundo LEFEVRE. os depoimentos são a matéria prima das pesquisas qualitativas, uma vez que são portadores das representaçỏes sociais dos entrevistados. Recupera-se, assim. a "fala do social". isto é, os "discursos que têm como emissores os grupos, coletividades, classes, extratos sociais" (LEFÉVRE 1998).
} 
Por meio dessas falas, pretendeu-se recuperar a "fala do social", razão pela qual o conjunto de sujeitos a ser investigado na escola foi significativamente representativo das forças que a impulsionam - ou a retardam - no seu caminho de se transformar numa escola promotora de saúde. Julgou-se oportuno envolver não apenas os profissionais que trabalham no interior da escola (diretora, professoras e coordenadoras pedagógicas), mas também os que a supervisionam e representam o elo entre a escola e o sistema educacional (supervisor de ensino e dirigente da Diretoria de Ensino).

\section{Instrumental utilizado}

Os dados foram levantados por meio de entrevistas semi-estruturadas ${ }^{32}$. Inicialmente, elaborou-se um conjunto de questões consideradas básicas para permitir a aproximação dos entrevistados ao objeto desta pesquisa: a escola como uma agência de promoção de saúde, as concepções sobre o papel da saúde e da educação e as interfaces entre saúde e educação escolar. Após pré-testagem, chegou-se finalmente a um conjunto de questões $^{33}$ que deveriam funcionar como uma espécie de eixo articulador das entrevistas, sem impedir que os sujeitos investigados pudessem falar livremente sobre $o$ tema em questão. A julgar pelos resultados obtidos, o roteiro cumpriu este papel, permitindo o levantamento de dados relevantes sobre a realidade escolar, conforme a percebem seus atores, dados estes expressos em suas opiniões, descrições de seus comportamentos, atitudes e crenças, entre outras manifestações.

Cada entrevista foi planejada para durar entre 50 e 60 minutos: todas elas foram realizadas na própria escola, portanto, um local familiar e de fácil acesso aos entrevistados. As entrevistas foram gravadas, com a devida permissão dos entrevistados e, posteriormente, o conteúdo das fitas foi transcrito integral e literalmente.

2. Análise dos depoimentos

\footnotetext{
32 Por "entrevista semi-estruturada" esta-se entendendo aquela onde "há combinação entre perguntas fechadas e abertas. onde o entrevistado pode discorrer sobre o tema proposto sem respostas ou condiçỏes pré-fixadas rigidamente pelo pesquisador" (SIMIONI 1996)

${ }^{33}$ A este conjunto de questỏes chamar-se-á "roteiro da entrevista". Segundo TRIVIÑOS, este roteiro marca a "presença" do investigador, sem tolher a espontaneidade dos entrevistados. O autor afirma, aliás, que a entrevista semi-estruturada "oferece todas as perspectivas possiveis para que o informante alcance a liberdade e a espontaneidade necessárias, enriquecendo a investigação" (TRIVIÑOS 1987).
} 
Há inúmeras possibilidades para se proceder à análise de discursos. Dentre estas, a análise de conteúdo permite que se possa compreender o significado das comunicações, ou seja, seu conteúdo manifesto ou significações explícitas. Logo de saída, esta foi a opção para o tratamento dos depoimentos. Tratava-se, ainda, de selecionar técnicas mais adequadas à natureza do que se investigava e a opção foi pela análise temática. ${ }^{34}$ Segundo esta opção, a unidade de significação buscada em cada um dos depoimentos - e no conjunto deles - foi o tema, também designado como "núcleo de sentido". ${ }^{35}$ Com efeito, julgou-se oportuno buscar na fala dos sujeitos, as palavras, frases e/ou expressões que guardassem algum tipo de significação em relação ao que esta investigação se dispôs a registrar, agrupando-as segundo critérios descritos no capítulo II deste documento.

Após esta opção metodológica, tratava-se de estruturar as etapas para proceder à análise temática. De maneira geral, MINAYO (1994) e TRIVIÑOS (1990) indicam que esta análise deve obedecer a três etapas básicas. Na primeira delas - a fase de préanálise - os depoimentos são preliminarmente analisados e organizados. São realizadas leituras flutuantes, para assinalar as palavras e/ou expressões significativas, segundo os objetivos da própria investigação, mas ainda se trabalha com a transcrição integral dos depoimentos. Inicialmente, foi o que se fez: inúmeras leituras asseguraram um contato mais íntimo com todo o material disponível; da mesma maneira, palavras e/ou expressões grifadas permitiram um pré-delineamento das idéias (ou temas) expressos nas entrevistas.

$\mathrm{Na}$ segunda fase da análise temática, o material coletado foi propriamente ...explorado. ${ }^{36} \mathrm{~A}$ partir do conteúdo das frases e/ou expressões assinaladas na leitura flutuante, definiram-se categorias suficientes e necessárias para incorporar todas as falas dos entrevistados.

\footnotetext{
${ }^{34}$ Entre as várias técnicas para análise de conteúdo, MINAYO (1994) cita a análise da expressão, a análise das relaçðes, a análise de avaliação ou representacional, a análise da enunciação e, finalmente, a análise temática.

${ }^{35}$ Segundo BORDIN apud MINAYO (1994), "o tema é a unidade de significação que se liberta de um texto analisado segundo critérios relativos à teoria que serve que guia à leitura".

${ }^{36}$ Para MNAYO (1994), trata-se da fase de "exploração do material"; já para TRIVIÑOS (1992), é a fase da "descrição analítica".
} 
Há inúmeras possibilidades para se proceder à análise de discursos. Dentre estas, a análise de conteúdo permite que se possa compreender o significado das comunicações, ou seja, seu conteúdo manifesto ou significações explícitas. Logo de saída, esta foi a opção para o tratamento dos depoimentos. Tratava-se, ainda, de selecionar técnicas mais adequadas à natureza do que se investigava e a opção foi pela análise temática. ${ }^{34}$ Segundo esta opção, a unidade de significação buscada em cada um dos depoimentos - e no conjunto deles - foi o tema, também designado como "núcleo de sentido". ${ }^{35}$ Com efeito, julgou-se oportuno buscar na fala dos sujeitos, as palavras, frases e/ou expressões que guardassem algum tipo de significação em relação ao que esta investigação se dispôs a registrar, agrupando-as segundo critérios descritos no capítulo II deste documento.

Após esta opção metodológica, tratava-se de estruturar as etapas para proceder à análise temática. De maneira geral, MINAYO (1994) e TRIVIÑOS (1990) indicam que esta análise deve obedecer a três etapas básicas. Na primeira delas - a fase de préanálise - os depoimentos são preliminarmente analisados e organizados. São realizadas leituras flutuantes, para assinalar as palavras e/ou expressões significativas, segundo os objetivos da própria investigação, mas ainda se trabalha com a transcrição integral dos depoimentos. Inicialmente, foi o que se fez: inúmeras leituras asseguraram um contato mais íntimo com todo o material disponivel; da mesma maneira, palavras e/ou expressões grifadas permitiram um pré-delineamento das idéias (ou temas) expressos nas entrevistas.

$\mathrm{Na}$ segunda fase da análise temática, o material coletado foi propriamente ...explorado. ${ }^{36} \mathrm{~A}$ partir do conteúdo das frases e/ou expressões assinaladas na leitura flutuante, definiram-se categorias suficientes e necessárias para incorporar todas as falas dos entrevistados.

\footnotetext{
${ }^{34}$ Entre as várias técnicas para análise de conteúdo, MINAYO (1994) cita a análise da expressão, a análise das relaçð̃es, a análise de avaliação ou representacional, a análise da enunciação e, finalmente, a análise temática.

${ }^{33}$ Segundo BORDIN apud MINAYO (1994), "o tema é a unidade de significaçåo que se liberta de um texto analisado segundo critérios relativos à teoria que serve que guia à leitura".

${ }^{36}$ Para MNAYO (1994), trata-se da fase de "exploração do material"; já para TRIVIÑOS (1992), é a fase da "descrição analítica".
} 
$\mathrm{Na}$ terceira fase, a partir da análise do conteúdo das frases e/ou expressões anteriormente assinaladas, foram definidos os temas e/ou sub-temas referidos na fala dos entrevistados, temas estes devidamente distribuídos pelas respectivas categorias, segundo a sua pertinência. Chegou-se, desta maneira, a uma espécie de mapa do conteúdo da fala dos entrevistados e vale a pena salientar que, até este momento, ainda não se havia recortado as falas dos entrevistados.

Tratava-se, portanto, de trabalhar os seus depoimentos, agora analisando os seus conteúdos e agrupando-os pelos temas e/ou sub-temas. Para tanto, recorreu-se a três das quatro figuras metodológicas propostas por SIMIONI et al.(1996), introduzindo-se as adaptações necessárias para que melhor se ajustassem à natureza do material recolhido e à opção inicial de se trabalhar com temas:

- seleção das expressões-chave: o depoimento de cada sujeito foi recortado; os recortes, por sua vez, foram distribuídos pelos temas e/ou sub-temas. Ao término desta fase, já se podia identificar os temas e/ou sub-temas que emergiram da fala de cada entrevistado e, além disso, como cada entrevistado se pronunciou a respeito destes temas. Não é demais insistir que a unidade de análise ainda era o discurso de cada entrevistado;

- definição da idéia central: as expressões-chave, anteriormente recortadas, foram retomadas, agora com o intuito de chegar a uma espécie de síntese do seu conteúdo discursivo. O desafio, agora, era construir um referencial que permitisse uma visão panorâmica da percepção do grupo a respeito de cada tema e/ou sub-tema - e, a esta altura, a unidade de análise deixara de ser o discurso de cada entrevistado para ser o conjunto dos discursos dos entrevistados;

- elaboração do discurso do sujeito coletivo: definidas as idéias centrais presentes em cada tema e/ou sub-tema, partiu-se para a construção de um discurso-síntese que pretendeu reunir todos os elementos dos diferentes depoimentos, agora organizados segundo as respostas dadas a cada item do roteiro de entrevista. Para tanto, recorreu-se sempre a fragmentos das entrevistas; quando o conteúdo dos discursos era basicamente o mesmo, optou-se arbitrariamente pela forma que melhor transmitia a idéia central anteriormente explicitada. 
Finalmente, procedeu-se ao tratamento dos produtos obtidos - ou à "interpretação referencial" -, na qual os materiais até então elaborados - categorias, quadro de referências, por exemplo - , foram objeto de uma reflexão mais intensa e profunda, para que se tivesse uma primeira percepção sobre as relações existentes entre o conteúdo empírico dos depoimentos e os referenciais teóricos que embasam esta pesquisa.

\section{B. Procedimentos metodológicos}

No início desta investigação, realizou-se uma pesquisa documental ou histórica ${ }^{37}$, para levantar as concepções sobre "promoção de saúde" e "escolas promotoras de saúde" vigentes no sistema educacional brasileiro. Lançou-se mão da chamada "documentação de primeira mão"38, em especial, os "Parâmetros Curriculares Nacionais" publicados pelo Ministério da Educação.

Definidos, portanto, os referenciais teóricos, elaborado e pré-testado o préroteiro da entrevista, teve início o trabalho de campo, propriamente dito, segundo os procedimentos descritos a seguir.

\section{Procedimentos para a coleta e transcrição dos dados}

Inicialmente, o projeto desta pesquisa foi apresentado à Diretoria de Ensino na qual se desejava realizar o estudo; posteriormente, à diretora da escola que se desejava investigar, previamente selecionada dentre um conjunto de escolas estaduais que atendiam a alguns critérios (ver Anexo 2, com a caracterização da escola selecionada). ${ }^{39}$

\footnotetext{
${ }^{37}$ Segundo NOGUEIRA, "quando as pesquisas sobre as formas de organização dos grupos humanos resultarem da ordenação de documentos, compilados segundo sua origem e finalidade e sistematizados com o intuito de registrar a evolução de determinado objeto de interesse, no desenvolvimento das sociedades humanas, no tempo e no espaço no qual se inserem, constituem as pesquisas do tipo histórico". Este estudo focalizará apenas os documentos produzidos a partir da nova Lei de Diretrizes e Bases, registrando o atual estágio do discurso oficial na área da promoção da saúde na escola, uma vez que a análise das fases anteriores encontra-se devidamente realizada em inúmeros estudos (NOGUEIRA 1979).

${ }^{38}$ Segundo GIL, os documentos de primeira mão - entre os quais se incluem os "documentos oficiais"constituem-se em fontes documentais que não receberam nenhum tratamento analítico anterior, ao menos no que se refere aos aspectos abordados pela pesquisa que deles se utiliza (GIL 1994).

${ }_{39}$ Ressalte-se, mais uma vez, que se buscou uma escola que, reconhecidamente, é encarada pela comunidade e pelo sistema educacional como uma escola de boa qualidade. Além disso, optou-se pela realização do estudo numa escola da região da Grande São Paulo - aquela que tem apresentado os problemas educacionais mais agudos no Estado -, que ofertasse Ensino Fundamental de $1^{\circ}$ a $8^{\circ}$ série $e$ Ensino Médio e, ainda, que já tivesse participado do Programa "Prevenção também se ensina", programa este que promove discussð̃es sistemáticas sobre AIDS e Doenças sexualmente transmissíveis nas escolas da rede estadual paulista.
} 
disposições semelhantes, o que significa que a sua fala pode ser tomada como a de sujeitos sociais.

Segundo esta ótica, procurou-se definir critérios para que os sujeitos a serem selecionados para a pesquisa fossem representativos da equipe escolar, refletindo as condiçð̃es históricas, sócio-econômicas e culturais do grupo.

Para tanto, fez-se o levantamento e a caracterização de toda a equipe escolar, composta de 51 profissionais, $72,5 \%$ sexo feminino, todos portadores da qualificação exigida para o exercício da função exercida na escola (vide Anexo 4).

De início, julgou-se que se devesse incluir apenas os profissionais que reconhecidamente desempenham um papel decisivo para que a escola se afirme como uma "escola promotora de saúde"; após inúmeras pesquisas e discussões com especialistas na área da pesquisa qualitativa, optou-se por trabalhar com uma amostra que fosse representativa do conjunto dos profissionais da escola, utilizando-se, para tanto, de critérios relativos a sexo, faixa etária, qualificação profissional, tempo de exercício no magistério e na escola em questão. A análise destes dados levou à seleção de nove pessoas; ao grupo previamente selecionado, agregou-se a diretora da escola, o seu supervisor de ensino e o dirigente da Diretoria de Ensino de Carapicuíba, onde se localiza a escola, chegando-se a doze profissionais ${ }^{40}$.

3. Procedimentos para a organização dos discursos e das categorias

Depois da leitura flutuante do conjunto das entrevistas, passou-se à identificação dos temas abordados pelos sujeitos. Verificou-se, no entanto, que os discursos inspirados pelas sete questões da entrevista podiam ser reagrupados em quatro grandes categorias e foi o que se fez (Anexo 5). Por sua vez, cada uma destas quatro categorias permitia agrupar os diversos temas e/ou sub-temas expressos nas doze entrevistas. Observe-se que até este momento ainda não se havia procedido a nenhum recorte nas falas dos entrevistados e o que se pretendeu foi apenas elaborar um instrumento auxiliar que melhor orientasse a segunda leitura das entrevistas (vide Anexo 6).

\footnotetext{
${ }^{40}$ No sistema estadual paulista, o supervisor de ensino tem sob sua responsabilidade um conjunto de escolas públicas e/ou privadas. No caso da escola pública, espera-se que este profissional atue como um agente da melhoria da qualidade de ensino, razło pela qual este profissional foi incluido nesta pesquisa.
} 
A seguir, procedeu-se a uma nova leitura de cada uma das entrevistas, agora com a preocupação de recortá-la e agrupar os respectivos recortes segundo os temas ou subtemas aos quais se referissem. Os recortes da entrevista do sujeito de número 1 foram designados como "Discurso 1"; os da entrevista do ator de número 2, como "Discurso 2" e assim sucessivamente, até o " Discurso $12^{\prime \prime}$, contendo os recortes da $12^{\circ}$ entrevista. Desta maneira, foram elaboradas doze fichas - uma para cada entrevista - , registrandose, em cada ficha, as expressões que fluíram da fala dos entrevistados - designadas como "expressões-chave" - , devidamente agrupadas no tema e/ou sub-tema ao qual se referiam (vide Anexo 7). $\mathrm{Na}$ medida do possível, buscou-se observar uma rigorosa correspondência entre a natureza de cada expressão-chave e o respectivo tema na qual a expressão foi agregada. No entanto, este rigor nem sempre pode ser observado, até porque entre uma e outra expressão há uma saudável afinidade. Além disso, como toda classificação, esta também é arbitrária, podendo ser contestada, a despeito dos cuidados observados na análise.

Após a classificação das expressões-chave de cada uma das entrevistas segundo seus respectivos temas e/ou sub-temas, passou-se para a fase de proceder às agregações possiveis entre estas expressões-chave, até chegar finalmente às idéias centrais do conjunto das entrevistas. As idéias centrais foram agrupadas em quatro categorias : características de uma boa escola, características de uma escola saudável, papel da escola na área da saúde e características do processo de construção de uma escola saudável (vide Anexo 8). Para cada uma dessas categorias, elaborou-se um conjunto de fichas - na primeira coluna, foram registradas as respectivas idéias centrais; na segunda coluna, as expressões-chave que deram origem a tais idéias centrais, expressões estas precedidas da identificação do discurso do qual fora recortadas (D.1, D.2, etc.).

\section{Informações sobre os sujeitos}

Conforme já referido, a pesquisa realizou-se numa escola estadual localizada numa cidade da região metropolitana de São Paulo (vide Anexos 1 e 2). Dela participaram doze sujeitos. cujas caracteristicas foram registradas no quadro seguinte. 
Quadro 1- Informações sobre cada um dos sujeitos envolvidos na pesquisa, segundo características individuais e profissionais.

\begin{tabular}{|c|c|c|c|c|c|c|}
\hline \multirow[t]{2}{*}{ Sexo } & \multirow[t]{2}{*}{ Idade } & \multirow[t]{2}{*}{\begin{tabular}{|l|} 
Estado \\
Civil
\end{tabular}} & \multirow[t]{2}{*}{$\begin{array}{l}\text { Formação } \\
\text { Universitária }\end{array}$} & \multirow[t]{2}{*}{$\begin{array}{c}\text { Função exercida } \\
\text { na escola }\end{array}$} & \multicolumn{2}{|c|}{$\begin{array}{l}\text { Tempo de exercício } \\
\text { (em anos) }\end{array}$} \\
\hline & & & & & Na escola & No magistério \\
\hline $\mathbf{M}$ & 52 & Casado & Letras e Pedagogia & Dirigente da DRE & 05 & 36 \\
\hline $\bar{M}$ & 51 & Casado & História e Pedagogia & Supervisor & 04 & 29 \\
\hline $\mathrm{M}$ & 28 & Solteiro & Ciências Sociais & PEB-II* - História & 03 & 05 \\
\hline $\mathrm{F}$ & 50 & Casada & Pedagogia & Diretora & 02 & 10 \\
\hline $\bar{F}$ & 50 & Casada & História & $\begin{array}{l}\text { Coordenadora } \\
\text { Pedagógica }\end{array}$ & 01 & 20 \\
\hline $\bar{F}$ & 28 & Casada & $\begin{array}{l}\text { Química, Ciências e } \\
\text { Pedagogia }\end{array}$ & $\begin{array}{l}\text { PEB-II* - Química } \\
\text { e Ciências }\end{array}$ & 02 & 07 \\
\hline $\bar{F}$ & 41 & Casada & $\begin{array}{l}\text { Habilitação } \\
\text { Magistério }\end{array}$ & PEB-I** - 1 série & 18 & 22 \\
\hline $\mathbf{F}$ & 44 & Casada & $\begin{array}{l}\text { Habilitação } \\
\text { Magistério }\end{array}$ & PEB-I** - 2 série & 15 & 18 \\
\hline $\bar{F}$ & 30 & Solteira & Educação Física & $\begin{array}{l}\text { PEB-II*- } \\
\text { Educação Física }\end{array}$ & 02 & 08 \\
\hline $\bar{F}$ & 47 & Casada & Letras e Pedagogia & $\begin{array}{l}\text { PEB-II* - } \\
\text { Português e Inglês }\end{array}$ & 04 & 13 \\
\hline $\bar{F}$ & 36 & Solteira & Educação Artística & $\begin{array}{l}\text { PEB-II* - } \\
\text { Educação Artística }\end{array}$ & 09 & 16 \\
\hline $\bar{F}$ & 33 & Casada & Matemática & $\begin{array}{l}\text { PEB- II* - } \\
\text { Matemática }\end{array}$ & 15 & 16 \\
\hline
\end{tabular}

- PEB-II Professor de Educaçào Básica II - atua no segmento de $5^{2}$ a $8^{2}$ série e no Ensino Médio;

** PEB-I Professor de Educação Básica I - atua no segmento de I"a 4" série.

Conforme se verifica, do conjunto de pessoas entrevistadas, a maioria delas é do sexo feminino, é casada, já passou dos 35 anos, é efetiva na escola, possui a devida habilitação para a função ou cargo que desempenha, atua no magistério há mais de 15 anos e na escola. há mais de 4 anos.

Esta situação, aliás, pode ser melhor comprovada por meio do quadro seguinte, que classifica os atores entrevistados segundo suas caracteristicas individuais e/ou profissionais. 
Quadro 2- Caracteristicas individuais e profissionais do conjunto de atores envolvidos na pesquisa, segundo sexo.

\begin{tabular}{|c|c|c|c|}
\hline \multirow{2}{*}{\multicolumn{2}{|c|}{ CARACTERISTICA ANALISADA }} & \multicolumn{2}{|c|}{$S E X O$} \\
\hline & & \multirow{2}{*}{$\frac{\text { Feminino }}{02}$} & \multirow{2}{*}{$\begin{array}{r}\text { Masculino } \\
01\end{array}$} \\
\hline Estado Civil & Solteira & & \\
\hline & Casada & 08 & 02 \\
\hline \multirow{4}{*}{ Idade } & Até 30 anos & 02 & 01 \\
\hline & De 31 a 40 anos & 02 & 0 \\
\hline & De 41 a 50 anos & 06 & 0 \\
\hline & Mais de 50 anos & 0 & 02 \\
\hline \multirow[t]{2}{*}{ Vínculo empregatício } & Efetivo & 08 & 02 \\
\hline & Não efetivo & 02 & 01 \\
\hline \multirow[t]{4}{*}{ Formação universitária } & Apenas Habilitação & & \\
\hline & Magistério & 01 & 0 \\
\hline & Licenciatura Curta & 0 & 0 \\
\hline & Licenciatura Plena & 09 & 03 \\
\hline \multirow{4}{*}{$\begin{array}{l}\text { Tempo de exercicio na } \\
\text { escola }\end{array}$} & Até 5 anos & 05 & 03 \\
\hline & Entre 5 e 10 anos & 02 & 0 \\
\hline & Entre 10 a 15 anos & 02 & 0 \\
\hline & Entre 15 a 20 anos & 01 & 0 \\
\hline \multirow{6}{*}{$\begin{array}{l}\text { Tempo de exercício no } \\
\text { magistério }\end{array}$} & Até 5 anos & 01 & 01 \\
\hline & Entre 5 e 10 anos & 03 & 0 \\
\hline & Entre 10 a 15 anos & 01 & 0 \\
\hline & Entre 15 a 20 anos & 04 & 0 \\
\hline & Entre 20 e 30 anos & 01 & 01 \\
\hline & Mais de 30 anos & 0 & 01 \\
\hline
\end{tabular}

Explicitados os procedimentos que foram observados para o tratamento das entrevistas. trata-se agora de explicitar os resultados obtidos. o que se fará no próximo item. 


\section{APRESENTANDO RESULTADOS}

Neste capitulo, serão apresentados os resultados obtidos com a análise das doze entrevistas, segundo a metodologia descrita no capítulo anterior. ${ }^{41}$

\section{A. As categorias encontradas}

Iniciada a fase de escuta das entrevistas gravadas, percebeu-se, desde logo, que os depoimentos estimulados pela questão de número 7 - "Quais as diferenças entre a sua escola e as demais escolas da região?" - , na prática, constituiam-se num detalhamento quando não, na ratificação - do depoimento dado à questão de número 1 , na qual se perguntava: "Você considera que a sua escola é uma boa escola? Sim? Não? Por quê?". Por sua vez, quando os entrevistados se pronunciavam sobre as três últimas questões do roteiro $^{42}$, o que faziam, na verdade, era revelar a sua percepção a respeito do processo de construção de uma escola saudável. ${ }^{43}$ Desta maneira, o grosso do material obtido girava em torno de quatro grandes categorias: caracterização de uma boa escola, caracterização de uma escola saudável, papel da escola na área da saúde e processo de construção de uma escola saudável. Sobre cada uma destas categorias, os sujeitos referiram-se a inúmeros temas; em alguns casos, cada um destes temas ensejou que tratassem de múltiplos aspectos. À medida que este universo de categorias, temas e subtemas foi sendo construido, tinha-se a nítida sensação de que se olhava num caleidoscópio: a cada olhar da pesquisadora, um rearranjo novo, a despeito de que se tratasse da recombinação das mesmas peças. O exercício de identificar o conjunto destas peças foi instigador e exaustivo - o produto encontra-se no Anexo 5. Observe-se que, na primeira coluna, foram mencionadas as quatro grandes categorias, já aqui referidas; na segunda coluna, por sua vez, registraram-se os temas e sub-temas relacionados a cada uma destas categorias. Assim, por exemplo, nas categorias "Características de uma boa escola" e "Características de uma escola saudável", os discursos referiram-se a aspectos

\footnotetext{
41 Ainda que a transcrição das entrevistas seja também um dos resultados desta investigação, o volume significativo do material inviabiliza a sua apresentaçåo no corpo deste trabalho.

${ }_{42}$ As três últimas questoes do roteiro de entrevista eram: "O que é essencial para que a escola se torne saudável?", "Quanto tempo leva para que a escola se transforme numa escola saudável?" e "O que é necessário fazer para que a escola se transforme numa escola saudável?".

${ }^{43}$ Ressalte-se que todos os sujeitos apontaram a sua escola como uma boa escola e uma escola saudável.
} 
da estrutura e ambiente físico da escola, da gestão escolar e da qualidade do ensino ministrado na escola. ${ }^{44}$ No caso do tema "ambiente fisico", as referências foram bastante genéricas e todas elas, sem nenhum esforço, eram facilmente reconheciveis como sendo genuinamente integrantes deste tema. No entanto, quando os discursos referiam-se ao tema "qualidade do ensino", versavam sob uma gama de aspectos que mereceram receber designações diferenciadas, como, por exemplo, "bons resultados do rendimento escolar" e "otimização do tempo pedagógico", entre outros.

Este instigante quebra-cabeças - cuja pretensão era apreender todas as intenções das falas dos sujeitos - foi sendo pouco a pouco completado quando, a cada sub-tema ou tema, foram agregados recortes das tais falas, tomando-se um a um os doze discursos. $\mathrm{O}$ anexo 7 registra este produto do trabalho : são doze discursos e, para cada um deles, são explicitadas as quatro categorias, acompanhadas dos respectivos temas e sub-temas. A coluna da esquerda registra as categorias; a coluna do meio, os temas e sub-temas referentes a cada uma das categorias; finalmente, na terceira coluna, são registradas as expressões-chave. ${ }^{45}$ Conforme se pode verificar, os doze discursos contêm alguma referência a cada uma das quatro categorias; no entanto, nem todos eles se referem aos mesmos temas ou sub-temas.

\section{B. As idéias-centrais identificadas}

A análise exaustiva das expressões-chave dos doze discursos, devidamente classificadas nas categorias, temas e sub-temas, revelou a necessidade de reagrupar alguns sub-temas, até para não se correr o risco de, em fragmentando demasiadamente o registro daquelas expressões, dificultar o processo de resgate do discurso do sujeito coletivo. Observe-se que não se tratava de abandonar a sistemática inicial, mas de fortalecer a percepção de cada uma das quatro categorias trabalhadas, para se chegar

\footnotetext{
${ }^{44}$ A despeito de que a definição de categorias tenha sempre uma margem de arbitrariedade, buscou-se tomar como referência, no caso de escolas de boa qualidade, a nomenclatura que vem sendo mais utilizada nesta área. Assim, à primeira vista, pode-se considerar que "geståo escolar" e "qualidade de ensino" sejam categorias inseparáveis - no entanto, as pesquisas educacionais, embora considerem a estreita relação entre estes dois aspectos, têm se referido à geståo escolar para designar as estratégias e/ou estruturas das quais as escolas se valem para administrar o seu cotidiano, reservando às estratégias e/ou estruturas que estão mais afetas à relação professor-aluno a designação "qualidade de ensino".

${ }^{45}$ Conforme já se explicitou anteriormente, as expressðes- chave são transcriçðes literais de partes dos depoimentos que permitem o resgate da essência do conteúdo das entrevistas.
} 
com mais segurança às idéias centrais ${ }^{46}$ relativas a cada uma das categorias - e também dos temas ou sub-temas, quando este era o caso. O anexo 8 registra o produto desta fase do trabalho, resgatando as idéias centrais de cada uma das quatro categorias: características de uma boa escola, caracteristicas de uma escola saudável, papel da escola na área da saúde e processo de construção de uma escola saudável. Para cada uma destas categorias, foi organizado um quadro - na primeira coluna, foram construídas as idéias centrais; na segunda coluna, as expressões-chave, precedidas da indicação do discurso ao qual se referem. ${ }^{47}$

Apenas para exemplificar, no caso das características de uma boa escola, foram identificadas três idéias centrais ${ }^{48}$ no conteúdo discursivo das doze entrevistas:

- boa escola é aquela que tem uma boa estrutura física, é espaçosa, arrumada e tem muito verde;

- boa escola é aquela que tem tradição, conta com um projeto escolar bem definido, conhecido por todos, cuja direção é presente e eficiente, na qual a Associação de Pais e Mestres e Conselho de Escola funcionam bem, cujos professores têm seriedade e profissionalismo e na qual se conta com a estreita parceria da comunidade;

- boa escola é aquela que oferece ensino de qualidade e na qual os bons resultados de rendimento e desempenho escolar resultam de trabalho cujo foco é a permanência do aluno na escola e sua efetiva aprendizagem. Para tanto, a escola otimiza o tempo de permanência do aluno na escola e utiliza o espaço das horas de trabalho coletivo para que o grupo de professores adquira segurança para diversificar as atividades de ensino aprendizagem e utilizar materiais didático-pedagógicos, conseguindo a aprovação de professores e funcionários que a ela confiam a educação de seus filhos, sobrinhos e netos.

Os quadros do Anexo 8 permitem que se conheçam as expressões-chave que contribuíram para esta sintese e, ainda, as idéias- chave das demais categorias. Da

\footnotetext{
${ }^{46}$ Neste contexto, a idéia central pode ser encarada como a(s) afirmação(ðes) que traduz(em) a essência do conteúdo discursivo das entrevistas.

${ }^{47}$ Cada expressão-chave foi designada pela letra D (de discurso), seguida do número da entrevista da qual ela foi retirada.

${ }^{48}$ Observe-se que cada idéia-central refere-se a uma das categorias com as quais se lidou anteriormente: por sua vez, os elementos de cada idéia-central eståo ancorados nos temas e sub-temas já explicitados
} 
mesma maneira, forneceram os elementos para que se pudesse, finalmente, elaborar o produto mais substancial deste trabalho.

Julgou-se oportuno incluir algumas fotografias da escola, no Anexo 9, devidamente associadas a alguns trechos das expressões- chave, até para oferecer mais um referencial aos leitores.

\section{O resgate do Discurso do Sujeito Coletivo}

O Discurso do Sujeito Coletivo (DSC) representa o discurso sintese - ou os discursos síntese - de todo o conteúdo discursivo trabalhado e é fundamental que se tenha clareza de que isto não significa que os discursos individuais tenham sido sacrificados em nome de uma lógica que pretendia ter como produto uma (ou algumas) categorias unificadoras. ${ }^{49}$ Ao contrário, este(s) discurso(s) síntese, porque é(são) elaborado(s) com trechos das expressões-chave dos diferentes sujeitos, permite(m) que se tenha mais clareza, "de uma dada representação social e do conjunto das representações que conforma um dado imaginário" (LEFĖVRE 1998).

Afinal, o que pensam os sujeitos da escola investigada? Por que a consideram uma boa escola e uma escola saudável $?^{50}$ Quais as percepções que têm a respeito das ações que desempenham na área da saúde? Quais as suas representações a respeito do processo de sua escola para se transformar na boa escola e na escola saudável que ela é hoje? Pois imagina-se que estas respostas sejam dadas pelo DSC e que a equipe escolar possa se identificar com várias das percepções nele apresentadas. Da mesma maneira, pode ocorrer que esta mesma sensação de reconhecimento e familiaridade se repita em escolas que se encontrem no mesmo patamar da que foi objeto desta investigação.

Os produtos que se seguem foram elaborados a partir das respectivas idéias centrais, recorrendo-se às falas literais das pessoas, conforme já se afirmou

\footnotetext{
${ }^{49}$ Recapitulando os passos na elaboraçåo deste discurso, pode-se ter a impressão de que, na fase anterior, quando se chegou às idéias- centrais, as percepçðes individuais tivessem sido, aí sim, sacrificadas. A bem da verdade, a despeito de que se tivesse chegado à essência da fala dos sujeitos, mais que nunca a sua individualidade esteve assegurada o tempo todo, por meio do registro das suas expressðes-chave.

${ }^{50}$ Não é demais repetir que o conjunto dos entrevistados considerou que sua escola é uma boa escola e uma escola saudável.
} 
anteriormente. ${ }^{51}$ É bastante oportuno esclarecer que as percepções dos sujeitos quanto às características de uma boa escola e de uma escola saudável são bastante próximas, motivo que exigiu uma reflexão sobre como tais discursos seriam apresentados.

Uma primeira possibilidade era trabalhar com as duas categorias - boa escola e escola promotora de saúde - a despeito das semelhanças e interseções entre as percepções dos sujeitos relativas a tais categorias. Neste caso, inevitavelmente os discursos coletivos seriam bastante semelhantes, pelo menos no que se refere a estas categorias, podendo eventualmente provocar no leitor uma sensação de déjà vu.

Uma outra possibilidade era fundir as expressões-chave referentes a estas duas categorias em discursos coletivos únicos, protegendo o leitor do eventual sensação de que o texto se repete. Nesta hipótese, corria-se o risco de, ao proceder à fusão dos discursos referentes a estas duas categorias, fazê-lo segundo a ótica da investigadora, desvirtuando-se as intenções iniciais dos sujeitos.

Finalmente, optou-se pela apresentação, em separado, dos discursos do sujeito coletivo referentes a essas duas categorias, informando-se previamente o leitor do eventual inconveniente da repetição de alguns trechos de expressões - chave e esclarecendo que, a despeito das semelhanças, não há propriamente ...repetição, pois os conteúdos discursivos foram obtidos em momentos diferentes das entrevistas.

A apresentação dos pontos de interseção entre as representações sobre o que significa uma boa escola e uma escola saudável, por sua vez, foi a opção que se achou para a discussão dos resultados da investigação, a ser realizada no próximo capítulo.

1. Por que a escola é uma boa escola?

\section{Discurso da boa qualidade da escola associada à infra-estrutura adequada}

É óbvio que uma boa escola precisa ser limpa, ter equipamentos em ordem, funcionar adequadamente, ser agradável aos olhos, impressionar bem os alunos e a comunidade. Como aqui: uma escola limpa, uma escola bonita, limpa conservada, decente, tem boas instalações, não tem nada quebrado, nada fora de lugar. Temos

\footnotetext{
${ }^{51}$ Para cada uma das quatro categorias, elaborou-se um discurso do sujeito coletivo; por sua vez, para cada categoria, foram organizados tantos discursos quantas foram as idéias centrais que a compunham. Optouse pela inclusão da idéia central no título descritivo de cada discurso, ao invés de explicitá-la em separado.
} 
muitos recursos materiais, muito verde, muita flor, arborizada, uma escola arrumadinha, onde tudo funciona.

\section{Discurso da boa qualidade associada à tradição da escola, à clareza de seu projeto, à gestão escolar eficiente e à articulação estreita entre escola e comunidade}

Esta escola já tem este trabalho há algum tempo, enquanto que outras estão começando. Este trabalho já vem sendo feito há mais tempo, desde quando a escola foi fundada pela colônia italiana e eles têm conseguido manter essa coisa do início. Há pessoas que trabalham juntas há mais de 15 anos. Ninguém está só de passagem pela escola, só até arrumar uma coisa melhor.

Ela está na frente porque tem um projeto que é conhecido por todos. O grupo aqui sabe o que quer, o que vai fazer, como vai fazer. Os pais também sabem. Não digo que não poderiamos querer outra coisa melhor, mas a comunidade conhece e aprova o nosso projeto. Não dá para improvisar em educação: tem que planejar, tem que ter objetivo, tem que chegar a algum lugar, tem que corrigir rumos, tem que rever, tem que fazer de novo.

A escola tem um excelente relacionamento com a comunidade. É raro o final de semana que a escola não está aberta- a comunidade se responsabiliza por tudo e nunca tivemos nenhum problema. A comunidade não é o nosso problema, mas a nossa solução e eu conheço escolas cujo maior problema é a comunidade. Nossos Conselhos de Classe são feitos com os pais dos nossos alunos. As reuniões de pais e mães não são apenas para passar as notas dos filhos ou falar mal deles, mas para fazer um trabalho conjunto de verificar os problemas dos alunos e para resolver conjuntamente estes problemas.

Aqui todos têm o seu dever e todos cumprem este dever. Aqui têm regras claras: os alunos, a escola, os pais, todos sabem as regras. Se há qualquer problema, os pais são chamados. A resposta dos pais é sempre muito boa e eles têm e demonstram muito carinho. Respeitam o nosso trabalho e a escola em si, o prédio. Eles ajudam a fazer o que tem que ser feito, o que foi planejado. Ajudam a escola a ser boa. Eu não sei se eles respondem porque são mais abertos, são bons, ou porque nós somos insistentes, mas a resposta deles é boa. 
Esta é uma escola que tem direção e isto em dois sentidos: a diretora vive aqui e sabe qual é o seu papel - faz este papel muito bem. A equipe é muito interessada e entrosada. Sempre tem exceções, mas os professores que não querem nada com nada acabam saindo da escola porque o grupo pressiona para que todos trabalhem bem.

Não quero passar a impressão que não temos problemas - temos, mas a gente sempre procura uma solução. Não sei se é o grupo de professores, se são os pais, se é a direção. Acho que é o trabalho de todos e também a comunidade é muito participativa. Lá fora, temos muita violência e há professores que são ameaçados e escolas que são depredadas. Graças a Deus isto não acontece aqui - a comunidade protege o Fornasaro.

\section{Discurso da qualidade da escola associada à boa qualidade do trabalho pedagógico}

Não dá para falar em boa escola se a gente não fala que os alunos aprendem. Temos dificuldades, os alunos não são iguais, as classes também, mas os alunos têm um bom rendimento. Julgo que a escola tem conseguido que os alunos tenham um bom nivel, que dominem conhecimentos, que façam alguma coisa com estes conhecimentos, que sejam participativos.

Esta é uma boa escola, principalmente porque aqui hả uma preocupação como aluno - que o aluno esteja bem, que o aluno aprenda, que o aluno não abandone a escola. Nesta escola não vejo ninguém que não esteja voltado para a meta da escola que é a aula, a educação em si, o trabalho pedagógico com o aluno.

Esta escola é boa porque valoriza o tempo que o aluno fica na escola. Esta escola é taxada assim- todo mundo teve férias e nós tivemos recuperação. Tinha greve e a gente repunha aula minuto a minuto. A direção entrava na classe e não tinha $70 \%$ dos alunos - era outro dia de reposição. Nisso, esta escola sempre foi linha dura. Aqui não se junta aula - e isto acontece muito por aí. No noturno, é a mesma seriedade - não tem esta coisa de não ter aula, do aluno voltar cedo para casa. Os professores eventuais ${ }^{52}$ fazem um bom trabalho e acho que isto mostra que não estamos brincando

\footnotetext{
52 Professor eventual é a designação dada ao profissional que não é regente fixo de nenhuma classe ou turma. Este profissional permanece na escola e assume a(s) classe(s) dos profissionais que deixam de comparecer para a regência de turma e/ou aulas.
} 
aqui. Aconselhei amigas minhas a tirarem os filhos de escola particular que é boa $e$ trazer para cá que é melhor. Fazemos de tudo para que as nossas aulas sejam interessantes - usamos video, $T V$, fazemos atividades culturais fora da escola. A nossa biblioteca é muito boa e uma professora aposentada toma conta.

A escola é boa também porque tem bons professores. Eles não enxergam a escola como um emprego, mas também não acham que isto é sacerdócio. Trabalhamos sério e merecemos nosso salário. Em muitas escolas, os professores ficam inventando o que fazer nas HTPCs. Nós aprendemos a usar bem este tempo, trocando idéias sobre o que cada um fez na sua sala e deu certo, combinando o que cada um vai dar em sua disciplina, conversando sobre os alunos que estão com problemas de aprender ou mesmo de disciplina. Acho que a gente vai se aperfeiçoando e as aulas é que ganham ...os alunos ganham.

A escola é mesmo boa porque se não fosse, os nossos filhos não estudariam aqui. Você pode perguntar por ai quantos professores põem os filhos para estudar na escola onde trabalham. Eles podem até falar que a escola é boa, mas põem seus filhos na escola particular. Aqui, é raro uma classe em que o professor não dá aula para um parente seu. Você quer melhor atestado de que a escola é boa do que este?

2. Por que a escola é uma escola saudável?

Discurso de que a escola é saudável porque possui uma boa estrutura geral e reúne boas condições materiais e de conservação

A escola é saudável e a gente percebe pelo fato de ser uma escola bonita, uma escola que não é pichada, uma escola muito limpa, uma escola arborizada, organizada e todas as coisas estão no seu lugar Aqui não tem grades, nem andares ...não há portões trancados, ninguém fica isolado. Então estes valores de conservação do ambiente fisico estão todos incorporados. O pátio da escola é uma maravilha ...espaçoso, arejado, coberto, cercado por flores ....parece aquela definição de ilha ...em vez de água por todos os lados, são flores por todos os lados. Há bebedouros muito higiênicos e nós mandamos examinar a qualidade da água que eles bebem. Os alunos aprendem também aqui - lições de saúde, de higiene, de bons modos. Nós temos orgulho do refeitório daqui ..é limpo, arejado, clarinho ...acomoda umas trezentas crianças ou mais. A 
merenda é muito limpa - a diretora até gostaria que ela fosse mais diversificada, mas até os professores comem aqui. Nós não humilhamos os alunos oferecendo-lhes comida num ambiente inadequado.

Na biblioteca, outra prova de que as coisas acontecem bem. Há muitos livros, há quem oriente os alunos nas pesquisas, quem indique alguma coisa interessante para ler. Mesmo os que não têm nenhuma chance de ler em casa, podem encontrar esta possibilidade aqui.

O nosso salão de eventos permite uma série de atividades que aproximam as pessoas - não é só por meio do teatro, mas do video, da música.

As salas de aula são mais uma prova de que esta escola é saudável. Lá acontecem as coisas, lá os alunos aprendem a aprender, a respeitar o outro, ganham auto-estima. Lá acho que eles são felizes e eu vejo que não acontece isto só com os pequenos.

Também a sala de professores é um lugar muito saudável - uma mesa grande, onde as pessoas sempre estão se reunindo.

Discurso de que a escola é saudável porque tem um projeto claramente definido, é bem organizada, gerenciada com eficiência e conta com a participação e apoio dos pais dos alunos.

Quando a gente entra na escola pela primeira vez, a organização geral chama a atenção de qualquer um. O clima é muito bom aqui e as pessoas são felizes. Todos têm acesso à direção, ela conhece os pais e alunos pelo nome. Os alunos gostam daqui. Eles não fogem. Vez ou outra um dá uma escapada, mas nós ficamos no pé. O aluno tem liberdade de conversar com a direção, com a coordenação. Eles fazem as suas reivindicações.

Nesta escola, as pessoas têm um cargo e exercem este cargo. Nas outras escolas, o diretor não fica oito horas na escola - ele trabalha em dois lugares e aparece ou só para abrir ou só para fechar a escola. Aqui não: a diretora está presente o tempo todo - é comprometida, sabe o caso de cada aluno, conhece todos os professores - o vice diretor apoia o diretor e o trabalho é bem distribuido e o coordenador faz o trabalho 
pedagógico. Os professores gostam de trabalhar aqui - são sérios e aqui não tem professorinha, só professora - a gente jả conquistou isto.

A escola tem um projeto pedagógico concreto. Este projeto está muito preocupado com valores - valores morais, valores de aprendizagem ... os valores de conteúdo, estes estão presentes. Também os valores tipo solidariedade, relações humanas, tudo isto está presente.

A comunidade aprova o que a escola faz e também ajuda a que tudo ande bem. $A$ comunidade tem consciência de que esta é uma boa escola e uma escola saudável. Existe até uma pressão da comunidade para colocar um filho, uma filha aqui. Às vezes, até os pais de outros bairros querem colocar seus filhos aqui, porque sabem disso.

Acho que o ponto forte da escola é a participação dos pais. Fica mais fácil fazer um bom trabalho, um bom projeto, quando não se tem que brigar com a comunidade, quando os pais colaboram, quando respeitam a escola, quando a escola não é destruida nos finais de semana. O Conselho de Escola ${ }^{53}$ funciona bem, inclusive para discutir os resultados dos filhos na escola. Olha que isto é raro, pois os Conselhos de Escola são muito fechados para as questões pedagógicas.

\section{Discurso de que a escola é saudável porque os alunos e a comunidade são responsabilizados por sua conservação material}

Nós temos o hábito de fazer que os alunos e a comunidade sejam responsáveis pela conservação da escola. A escola é de todos - e isto vale para tomar conta da escola.

Nossos alunos sabem que têm que conservar a escola, pois ela é de todos e vai ser um dia dos filhos deles. Um dia, dois alunos quebraram alguns vasos - nós não brigamos - chamamos a familia, explicamos que aquilo era patrimônio nosso - e eles acertaram tudo. Um aluno riscou a mesa do professor - fizemos a mesma coisa. A mesa ficou mais limpa que antes. É um trabalho incansável. Sujou, tem que limpar na hora. Tem que conscientizar que a escola é nossa e nós temos que zelar por ela. Não vejo como uma escola pode ser boa ou ser saudável, não vejo como formar bons cidadãos se 
as crianças e as famílias não são chamadas à responsabilidade, com bons modos, com educação, com transparência. Não é sobrecarregar os pais, mas fazer com que assumam o que tem de ser assumido por eles.

Discurso de que a escola é saudável porque há uma preocupação com o bem estar de todos

Os professores daqui se preocupam com a comunidade e todo mundo pensa no bem estar de todos. Não só do corpo docente, mas também dos funcionários, dos alunos, em todos os aspectos. Não só na ausência da saúde ou na doença, mas no estado social das pessoas que se encontram na comunidade. Se eu fosse dar uma nota para esta escola, de zero a dez, eu tocava ela em 9,5 de escola saudável.

Esta escola preocupa-se muito também com a vida funcional do professor. A nossa vida é rigorosamente em dia - adicional, tudo em dia. Eu acho que isso deixa o professor satisfeito, é uma das coisas que segura o professor aqui.

O grupo tem uma preocupação para que a gente viva bem aqui dentro. Tenho amigas que trabalham em outras escolas e elas têm problemas de drogas, de violência ...é lógico que isto tem em todo lugar, mas nós não temos nada que atrapalhe o trabalho da escola.

Discurso de que a escola é saudável porque o foco do trabalho pedagógico é a permanência do aluno na escola e sua boa formação

A escola tem um compromisso com o aluno e nos esforçamos para não desviar a nossa atenção do que realmente interessa - do aluno.

A direção, a coordenação e os professores trabalham para o aluno, para que ele goste da escola, para que ele melhore a sua auto-estima, para que ele tenha sucesso, para que ele possa se dar bem aqui. Elas não deixam o aluno desistir nunca.

\footnotetext{
${ }^{33}$ O Conselho de Escola é um colegiado de natureza consultiva e deliberativa em assuntos referentes à gestão pedagógica, administrativa e financeira da escola. É formado por representantes de pais, alunos. professores e funcionários.
} 
A escola oferece o suporte necessário para que o aluno possa se expressar, se exercitar, para que ele possa ser ele lá fora, em todos os campos. Faz os alunos se sentirem felizes, a gente nota que existe um respeito um pelo outro. Os nossos alunos aprendem e dá muita satisfação de ver como vão progredindo ... eu sempre encontro meus ex-alunos, aqui mesmo na escola, e pergunto sobre como eles estão se saindo. E eles se saem bem ...é lógico que um ou outro nem vai tão bem assim.

\section{Discurso de que a escola é saudável porque diversifica as estratégias de aprendizagem}

Os professores usam muitos videos e a nossa videoteca é boa. Gravamos os programas da TV Escola ${ }^{54}$, compramos outros videos com recursos da $A P M^{55}$, emprestamos na Oficina Pedagógica ${ }^{56}$. Se precisamos de algum filme e não achamos em lugar nenhum, compramos e usamos. Material aqui não é para ficar guardado

Nós saimos sempre com os alunos - todos os anos vamos com eles à Bolsa de Valores e os nossos alunos são muito elogiados lá. Vamos à Coca Cola e dá para discutir sobre a produção, o capitalismo - a linha de montagem, a origem da matéria prima. Dá até para ver como somos explorados. Vamos ao Museu de Arqueologia, da USP, ao Museu do Crime, ao Teatro, a atividades culturais - a escola é um pólo cultural. As aulas melhoram, a comunidade fica orgulhosa de ver o trabalho dos filhos $e$ a escola fica cada vez mais saudável.

Discurso de que a escola é saudável porque os alunos são participativos e contribuem para isto com seu comportamento fora e dentro da sala de aula

Os alunos são muito participativos, são muito atentos, muito dedicados. Procuram estar uniformizados, procuram se vestir bem. Procuram se pentear.

\footnotetext{
${ }^{54}$ A TV Escola é um segmento da programação de educação continuada do Ministério da Educação. Os programas såo divulgados nas emissoras educativas, em diferentes horários, ou em sistema fechado e se destinam à capacitaçào de professores.

5s A APM - Associação de Pais e Mestres - é uma instituição escolar formada por representantes dos pais. professores e alunos. No caso do Estado de São Paulo, a transferéncia de recursos financeiros para as escolas é realizada diretamente para estas associaçðes.

${ }^{56}$ A Oficina Pedagógica é um órgão que funciona em cada uma das 89 Diretorias de Ensino do Estado de Såo Paulo. Conta com docentes especialistas nas diferentes áreas curriculares e tem como função principal a capacitação das equipes escolares. A Oficina Pedagógica conta com acervo de livros e videos para utilização nas açðes de capacitação e empréstimo às escolas.
} 
Procuram estar bem - vamos dizer - tomar banho. Os alunos procuram andar de maneira comportada, mais bonita. Dificilmente se vê aluno correndo, suado e a gente percebe isto - o grande convive com o pequeno e você nota que existe um respeito um pelo outro. Tudo isso são valores que estão estampados. Eles aparecem.

Se fala em voz num tom de voz bom, não há gritaria. Por isto esta escola é saudável - os alunos têm consciência de que a escola é saudável, é diferente das demais escolas e eles têm orgulho disso. E eles primam por continuar com este trabalho, com este orgulho. Eles procuram não destoar. Os alunos que se desviam, pedem desculpas.

Você não vê um pessoal feio aqui na escola ... você não vê pessoa raquitica e nós sabemos que a população que usa esta escola não é uma população de alto poder aquisitivo. Pelo contrário, é de médio para baixo. Mas você, olhando para os alunos. parece que eles são todos iguais. Eles se parecem fisicamente...

Os nossos alunos contribuem muito para que a escola seja boa e saudável. Não agem com violência, não usam palavrões - os alunos diferentes que chegam de fora ou seguem as regras daqui ou querem ir para escolas mais desorganizadas.

3. Quais as relações de reciprocidade entre as categorias "escola boa" e "escola saudável"?

\section{Discurso de que nem toda boa escola é uma escola saudável}

Eu fico pensando que esta é uma escola saudável e uma boa escola. Mas quero deixar claro que nem toda escola que é boa é saudável como esta. Tem uma escola em Carapicuiba que aos olhos da comunidade é uma escola boa. Só que eu não a vejo como saudável. Por quê? Porque a escola age com discriminação, em algumas situações. E onde houver discriminação, não existe o saudável.

Há escolas consideradas boas pela comunidade. mas que não têm nenhuma preocupação com a saúde, nem são saudáveis, nem promovem a saúde de ninguém. $O$ professor vai lá e faz o seu trabalho. Para que ela seja saudável, ela tem que brilhar e o profissional tem que dar a sua alma. a sua emoção. Ou eu vou e me dou por inteiro ou eu não consigo fazer uma escola saudável. Ela não só ensina, mas ensina para a vida...ela não fala só do que é bom, mas oferece um bom ambiente para o aluno e para todos. Tem escola que é boa no sentido tradicional - tem fama, faz o aluno entrar no 
vestibular - mas não promove a saúde dos alunos e nem é agradável por dentro, nem $\dot{e}$ saudável, como estamos dizendo. Já vi escola que é considerada boa que não está nem ai com a qualidade de vida dos alunos e que não tem este clima agradável daqui.

\section{Discurso de que toda escola saudável é uma boa escola}

Seria um contra-senso que uma escola boa não fosse saudável, não fizesse que os alunos fossem bem sucedidos! Acho que uma escola que é saudável tem também que ser boa, tem que fazer o aluno aprender - a educação não é um dos requisitos da saúde?

Será que a gente pode considerar saudável uma escola que expulsa o aluno, que não consegue fazer com que ele aprenda? Eu acho sinceramente que não e toda escola saudável tem a obrigação de ser uma boa escola. Aliás, penso que uma das condições para que ela seja saudável é que ela seja boa.

Estava querendo dizer que uma escola saudável é por natureza uma boa escola. A escola não é um hospital - é uma escola. E faz parte de ser saudável que ela faça bem o que precisa fazer, o que é só ela que faz-ensinar.

4. Qual o papel da escola na área da saúde?

\section{Discurso de que a escola deve promover a saúde dos alunos, articulando teoria e prática}

Eu não entendo muito bem disto, mas acho que aqui a escola fala e, ao mesmo tempo, mostra o que é saúde. É necessário manter a escola limpa ...e a escola é muito limpa; é preciso ler hábitos pessoais de higiene ...e os alunos mais novinhos que precisam aprender estes hábitos aqui, aprendem. Aprendem a tomar banho, a escovar dentes, tomam flúor. A escola também ensina como limpar. porque limpar - esta coisa de micróbios, por exemplo. Então eles têm a prática, eles vêem as coisas e a teoria. Acho que isto é promover a saude dos alunos e ela está sempre garantindo que as pessoas possam exercitar esses conhecimentos desde lá da primeira série até o aluno do último ano do Ensino Médio.

Acho que o papel da escola é promover a saúde e não apenas trabalhar a questão da doença. Precisa falar de higiene e estar numa escola limpa. Falar de escola 
saudável e estar estudando numa boa escola saudável, deixando a sala de aula limpa, o pátio limpo .

No ano passado, fizemos um projeto de obesidade da criança, pois começamos a ter este problema. No refeitório, as crianças aprendem a comer, a ter hábitos saudáveis, a não comer exagerado. Precisamos também garantir o conteúdo da saúde - fazer sempre a teoria casada com a prática. Temos que cultivar hábitos de higiene - temos trabalho com o piolho, toda $4^{a}$ feira nós aplicamos flúor nas crianças.

Esta coisa de formação para a saúde, de promoção da saúde, é necessária. Mas precisamos ensinar bem - o resto complementa o nosso trabalho. Precisamos de crianças sadias - não posso trabalhar com criança com dor de dente, com piolho, com dor de barriga - então temos que trabalhar com isto. A escola trabalha conteúdos $e$ oferece oportunidades para o aluno sinta, na prática, o que significa um ambiente saudável, uma vida saudável. Também para que ele pratique tudo isto dentro da sala de aula, no pátio, no recreio, na quadra e no refeitório.

\section{Discurso de que a escola deve transmitir conhecimentos de saúde e informações sobre estratégias de auto-proteção}

Eu acredito que a escola desenvolve um bom trabalho de saúde divulgando conhecimentos e tudo o que é informação sobre saúde. Tenho percebido que isto acontece em todos os projetos que a escola trabalha, em vários componentes curriculares, na área de ciências, biologia, sociologia, nas relações humanas e tudo isto é trabalhado pela escola com a comunidade.

Desde as séries iniciais, trabalhamos com higiene, sexualidade. Zelamos para que os menores tomem banho, ensinamos como usar Modess. Queremos que nossos alunos tenham nas escola uma referência, pois a escola tem um grande papel de estar colaborando para que os alunos tenham os conhecimentos certos de saúde. Na Educação Física, em Ciências, isto integrado com todas as outras disciplinas. A escola precisa trabalhar conteúdos de saúde. Nas minhas aulas eu sempre ajudo as outras professoras que estão trabalhando com conteúdos de saúde. 


\section{Discurso de que a escola deve orientar pais e alunos sobre as questões de saúde individual}

A escola tem que orientar sempre os alunos e também os pais. Em muitos casos, nem é necessário orientar os pais, pois eles são bem informados, mas como eles participam das nossas atividades, todos acabam sendo orientados nas reuniões, nas campanhas, nas palestras sobre AIDS, nas atividades do "Agita São Paulo" ${ }^{457}$. Orientar sobre hábitos de higiene, sobre doenças sexualmente transmissiveis, sobre os problemas dos filhos adolescentes.

Orientar é alguma coisa a mais do que apenas informar - informar também, mas discutir alguns pontos práticos que podem melhorar a vida deles e a vida da escola. $\dot{E}$ dar as dicas de como eles podem usar as informações, ainda que não se pode jurar que eles vão fazer, mas é papel da escola.

\section{Discurso de que a escola deve contribuir para a formação de valores}

Esta escola trabalha muito com a formação de valores e acho que por isto seu trabalho é bom. Nós trabalhamos com projetos nas aulas eventuais - cidadania e participação, nas $5^{a s}$. e $6^{a s}$. séries, preconceito e solidariedade, nas $7^{a s}$ e $8^{a s}$ séries; sexualidade e preconceito, na $1^{a}$ série do Ensino Médio, ética, no $2^{\circ}$ ano e diversidade cultural, na $3^{a}$ série. Estas questões envolvem valores e eles precisam ser discutidos.

Damos muita importância para que os alunos exercitem criar um ambiente em que um respeita o outro. Eu trabalho assim - eu exijo respeito, eu respeito. Eu gosto de disciplina e as crianças têm que saber o que é direito, o que é dever. Antes de ser politico, o ser é humano - e isto nós trabalhamos muito aqui.

Percebi que meus alunos não estão desenvolvendo certos valores - e achei necessário fazer isto. Alguma coisa para desenvolver a solidariedade, - vamos ajudar o seu coleguinha: vamos ajudar o outro! Se a gente faz isto de pequeno, quem ajuda não

\footnotetext{
57 O "Agita São Paulo" é um programa que vem sendo desenvolvido pelas Secretarias da Saúde, da Educação e de Esportes do Estado de São Paulo. Esta programa visa divulgar a necessidade da prática diária de exercicios, nas diferentes situaçỏes do cotidiano das pessoas. estimulando hábitos tais como subir e descer escadas, deixando de utilizar sistematicamente o elevador, entre outras.
} 
vai se considerar um Caxias ou um idiota. Quem precisa de ajuda, vai saber solicitar ajuda. Eu vejo o meu aluno muito tempo aqui dentro da escola e não apenas durante o ano que ele é meu aluno. Sigo ele ano a ano. Já vi aluno meu ser assassinado, já vi aluno meu virar médico. A gente consegue lembrar das caracteristicas dos alunos que não deram certo ...e eu fico atenta. Os que precisam mais, eu dou mais atenção. Na minha sala, a gente trabalha assim ...e também a escola toda.

\section{Discurso de que a escola deve encaminhar os alunos que precisam de atendimento na área da saúde}

Acho que a escola deveria contar com serviços de saúde. Nós tínhamos dentistas e na atual situação, o prefeito tirou os dentistas daqui. Mas temos que continuar com os encaminhamentos necessários, para o postinho da Prefeitura. Batalho para que os nossos alunos sejam atendidos e bem atendidos. Telefono para o pessoal da saúde, converso com as mães, com as crianças, verifico se foram bem atendidas.

Era mais fácil quando a gente tinha dois dentistas da prefeitura aqui, mas não podemos ficar lamentando. Acho que a escola também deve esclarecer aos alunos e às familias sobre como podem ser atendidos na comunidade, a quem procurar em caso de necessidade. Também devemos ficar atentos para perceber alguma situação que a familia não percebeu e encaminhar.

Discurso de que assegurar o sucesso escolar a todos os alunos é o papel básico da escola na área da saúde

O ponto que eu vejo positivo nesta escola é o seguinte: se eu tenho um problema com um aluno e o encaminho para a direção ou coordenação, nunca se parte para afastar o aluno. A escola procura conhecer o problema do aluno. Aqui, vale o ditado: bater não adianta - tem que recorrer ao diálogo. Nosso objetivo é trazer o aluno para a aula, para dentro da sala de aula - nunca afastar. E isto é o minimo que a escola precisa fazer para que os alunos sejam cidadãos com saúde - que saibam ler, escrever, conversar, argumentar...essas coisas. O papel da escola é fazer com que o aluno se torne uma pessoa, consiga viver de uma forma digna lá fora, é conseguir que o aluno venha e fique na escola - numa boa escola. Orientar, informar, viver aqui uma experiência gostosa, boa, interessante. Aprender. 
5. Como a escola se transformou numa escola saudável?

\section{Discurso sobre o processo gradativo de construção de uma escola saudável}

Uma escola boa e saudável não se faz do dia para noite e nem tem um dia em que ela amanhece saudável. Para que ela seja boa e saudável, precisa estar atenta todo o tempo, todos os dias, todos os minutos. Isto é diário... a cada dia a escola tem que tomar cuidado para não deixar de ser saudável. A escola não é saudável - ela está saudável. Se a escola tomar atitudes erradas, ela pode deixar de ser saudável. A escola é formada por pessoas e ela vai ser saudável dependendo se as pessoas que formam ela estão agindo neste objetivo, Por exemplo, se mudar a direção, se o diretor não tem mais este objetivo, se os professores não colaborarem, uma escola que é considerada saudável, no outro ano pode deixar de ser saudável.

Aos poucos você vai incorporando as coisas boas, tirando aquilo que é ruim. Eu acho que tem que parar, tem que pensar, analisar: o que não está bom, volta para trás. A escola precisa pelo menos ter uma caminhada de alguns anos, o grupo todo juntos, com uma equipe básica. Depois, é questão de sempre ir acertando o que ainda precisa acertar.

Manter uma escola boa e saudável é tarefa de todos e da vida inteira. Até a noção do que é uma boa e uma escola saudável muda com o tempo - assim, a escola não pode parar.

\section{Discurso sobre o que é essencial para que a escola se torne saudável}

Em primeiro lugar, acho que todos precisam estar sintonizados com um projeto único - e todos inclui também a comunidade. Se não tiver este coletivo, não dá para querer mudar a escola para melhor. Coletivo não é apenas juntar o povo da escola $-\dot{e}$ trazer a comunidade para dentro da escola, como esta escola faz e faz bem É preciso reunir os professores, reunir a comunidade constantemente - e a comunidade, aos poucos, vai assumindo a escola. Para que uma escola seja boa e saudàvel ela precisa se abrir por dentro, aparar as arestas, formar um grupo que faça mesmo e convença os outros a também fazerem o mesmo. Mas se abrir para fora também - repito muito, mas se a escola serve à comunidade, ela não é depredada, roubada, invadida. Hoje mesmo, 
nas horas de trabalho pedagógico, nós discutimos uma postura conjunta do corpo docente - dissemos que quem destoar, o grupo vai cobrar.

Aqui, nós temos muito a participação dos pais e isto tem sido fundamental. Os pais estão dentro da escola - na APM, no Conselho de Escola ...tenho muitos amigos que foram os pais dos meus alunos. Há um elo muito grande entre os professores, os alunos e os pais. Não é uma coisa de uma ou duas pessoas, nem só de dentro da escola. É uma tarefa do grupo da escola e da comunidade. Esta união dá força para todo mundo...quando alguém desanima, o outro está lá para encorajar

Precisa ter vontade de fazer ... precisa acreditar que se pode fazer, mas precisa de muita paixão para isto, conforme diz o Ruben Alves. Precisa arregaçar as mangas $e$ fazer. Precisa estimular toda hora e cobrar sempre. O que você percebe que num ano falhou, no outro você procura consertar. O que você viu que era bom, aumenta aquilo. Aquilo que você viu que era preciso ser feito, você chama alguém, pede ajuda. Se não for desse jeito, vendo cada passo, não dá. Precisa ter alguém que dê o start e que cobre sempre. Precisa ter alguém que alavanque. Ela tem que reunir um grupo de força que tenha as mesmas idéias. A partir dai, é questão de estabelecer combinações, estabelecer as regras do novo jogo. Precisa de alguém que consiga chamar pessoas para a mesma idéia ...precisa de ter força de convencimento.

Acho que as pessoas têm um pouco de medo do novo ...eu tenho, pelo menos. Para a escola ser cada vez melhor e mais saudável, ela precisa perder este medo. Se cada um souber que o outro também tem medo, acho que já é um passo para a frente. $O$ novo tem que ser melhor do que o velho ...não é qualquer novo... a educação está cheia de modismos. Para que a escola seja boa e saudável, a nossa preocupação tem que ser com o aluno. Nós temos que ter sempre isto presente, senão a gente se perde. Limpa a escola, compra materiais interessantes, faz passeios, mas nada que represente alguma coisa para o aluno. Se a escola muda e nada muda para melhor na sala de aula, acho que não adianta. Se o aluno se sente bem na escola, se a escola é limpa e bonita, se o professor dá uma aula boa, a escola será saudável.

Precisa mudar o conceito de escola - nosso pais rotula tudo - a nossa escola não está fracassada. Para começar, uma escola saudável precisa ser acreditada. Se os 
professores não acreditam, se os pais não acreditam, os filhos também não acreditam. Precisa mudar esta imagem da escola.

\section{Discurso sobre a colaboração da equipe de direção e supervisão para que a escola se torne saudável}

Aproximo as pessoas, sistematizo as nossas prioridades. Estimulo a participação de todos, busco manter elevada a auto-estima de cada um e da equipe. Acompanho o processo, da mesma maneira que dou uma mão e estimulo. Também vou cobrando aqui e ali, me certificando da necessidade de corrigir isto ou aquilo. Até sou chata, mas este é o meu papel. Nem sempre a gente consegue, mas a gente sente que é importante $e$ corre atrás.

Acho que tenho colaborado para melhorar a relação da escola e dos professores com os alunos e suas familias. Eu aprendi a conviver com os alunos e seus problemas $e$ tenho procurado, sempre que possivel, colocar a familia em contato com a escola e a escola também em contato com a casa do aluno. Ligo para mãe no serviço e me coloco à disposição dela a qualquer hora. Controlo o aluno que estava cabulando - vou à quadra, pergunto ao professa. Se a mãe não pode vir à reunião - e essas reuniões são muito importantes, pois se discute nelas o trabalho da escola- eu me disponho a atendêla em qualquer horário, á tarde, á noite. E tem dado certo. Tenho sempre disposição para o diálogo.

\section{Discurso sobre a colaboração dos docentes para que a escola se torne saudável}

Estou sempre me aprimorando e busco trazer coisas novas e interessantes parao aluno. Procuro o que tem de bom por ai e trago para cá, fazendo com que o aluno se expresse de várias maneiras, usando várias linguagens. Eu dou oportunidades para que todos se sintam capazes, para que eles se valorizem, tenham êxito, aceitem as diferenças, contribuam para o coletivo. Também busco interagir com os meus colegas. para que eles aproveitem o que puderem das coisas que eu arranjo fora.

O objetivo do meu trabalho são as crianças e acho que esta é a minha contribuição pessoal para que a escola seja boa e saudável. Pode parecer pouco, mas se todos fizerem bem a sua parte, as coisas vão entrando nos eixos, como aqui no 
Fornasaro. Para lidar com crianças, precisa ter amor. Tenho amor pelas crianças respeito as crianças e trabalho para elas. Faço o que posso e o que não posso para que o nosso trabalho seja interessante, para que elas se sintam bem na escola, para que possam progredir e se realizar na vida.

\section{Discurso sobre o receio quanto à descontinuidade do trabalho da escola para ser uma escola sempre mais saudável}

As pessoas aqui se acostumaram a uma sistemática de trabalho coletivo e a gente tem até medo das mudanças da Secretaria que possam acabar com este trabalho. Sei lá ...um sistema diferente de contratar professores, uma nova reorganização. E nisso, todo trabalho é quebrado e você vai de novo colocando aquele tijolinho. Ai, chega no final do ano - quebra. Sempre ficam algumas pessoas. E você consegue construir. E dá uma quebrada, mas você vai moldando de novo. Mas podia ser mais fácil ... a gente sempre fica com medo do que vai acontecer no próximo ano, se a equipe vai continuar na escola. Tenho sempre medo das reformas da Secretaria.

A progressão continuada pode deixar as pessoas displicentes, pois elas não entendem o espírito da coisa. Só registram que o Estado quer aprovar todo mundo e ficam desmotivados para fazer um trabalho sério na escola.

A familia está se distanciando muito dos filhos. Com o desemprego, as mães empregam no que der - diarista, qualquer horário. Ficam mais distantes da responsabilidade de zelar, conosco, pelos filhos. Confesso que tenho receio de que os pais não continuem no mesmo ritmo de sempre. No ano passado, um aluno cabulava aula todos os dias. Liguei para a mãe, várias vezes. Ela ficou irritada e disse que era papel da escola resolver disso. Se a familia perder este referencial - não se sentir responsável - vai ser mais dificil. Na recuperação de janeiro, achei que as mães ficaram pensando que os filhos poderão folgar durante o ano todo, pois terão recuperação nas férias. Tenho receio de que a violência aumente ...num final de semana, fizemos uma atividade - entrou uma gangue e veio um garoto de fora armado aqui, para falar com uma aluna. Um professor enfrentou a gangue ...tenho medo que as coisas possam mudar. Temos que pensar muito porque a violência é alguma coisa que mina o trabalho da escola. 


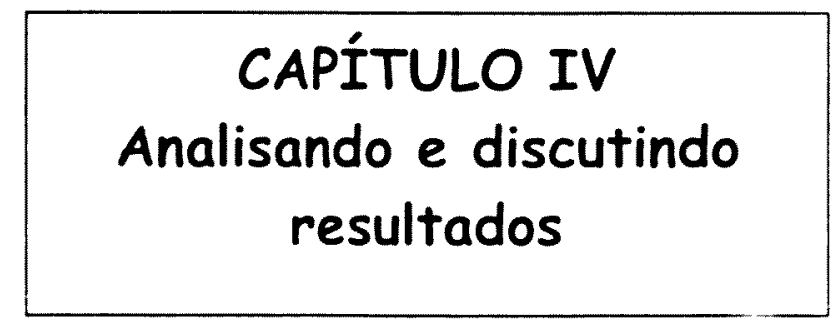




\section{ANALISANDO E DISCUTINDO RESULTADOS}

Neste capítulo, os resultados da investigação - relatados no capítulo anterior são retomados, com a finalidade de discutir alguns pontos, aprofundá-los, fazer extrapolações, sempre tendo como referência os fundamentos teóricos explicitados no Capitulo I, relativos à promoção da saúde e ao que se considera como características de uma escola de boa qualidade. Para facilitar a consulta, os comentários foram organizados em blocos (ou "temas"), ainda que se tenha bastante clareza que nem sempre se conseguiu manter obediência aos limites de cada bloco ou tema.

É importante salientar que se pretende(u) que esta investigação tivesse caráter apenas descritivo: saber o que pensa a escola sobre a sua performance no terreno da qualidade de ensino e da promoção da saúde e sobre sua caminhada nesta direção. Logo, estes comentários finais não têm a intenção de (re)interpretar os discursos do sujeito coletivo, muito menos qualificá-los ou, ainda, pensar em estratégias que permitam ao grupo pensar e agir de modo distinto, possivelmente mais compatível com os parâmetros da promoção da saúde, se este fosse o caso. Com efeito, tem-se absoluta clareza de que o sentido que o grupo da escola dá ao seu processo cotidiano de ser - e de permanecer uma boa escola e uma escola saudável, já está dado naqueles discursos. ${ }^{58}$

\section{A . Conjugando qualidade: boa escola e escola saudável}

Em primeiro lugar, merece destaque o fato de que todos os sujeitos entrevistados, independentemente da função desempenhada na escola, a consideram uma escola de boa qualidade e uma escola saudável, apresentando argumentos bastante próximos àqueles incorporados nos parâmetros que disciplinam o assunto.

\footnotetext{
${ }^{58}$ Segundo LEFĖVRE, há três níveis de análise do objeto de estudo: o descritivo, o interpretativo e o evolutivo. No primeiro caso, pode-se obter respostas do tipo "o que pensa a população $x$ sobre o tema $y$ ", que é o caso típico desta investigação; no nivel interpretativo, além de obter respostas de como pensa a população, seriam apontadas as razðes pelas quais ela pensa desta maneira. Finalmente, no terceiro nivel, depois de saber como e porque pensa de uma determinada maneira. o desafio é propor intervençðes para que ela passe a pensar de maneira supostamente mais adequada (LEFEVRE 2000).
} 
Em segundo lugar, deve-se salientar que os discursos do sujeito coletivo referentes às características de uma boa escola e de uma escola saudável foram bastante semelhantes, incorporando basicamente as mesmas idéias centrais. A despeito da heterogeneidade dos discursos individuais, o discurso do sujeito coletivo indica um conjunto de características físicas, de gestão escolar e de qualidade de ensino sem as quais nenhuma escola pode ser considerada nem boa nem saudável. E, ainda que esta percepção possa parecer óbvia, ela se distingue da percepção que tende a associar escola saudável à escola que, ou trabalha com doenças, ou atua na área do atendimento à saúde e, ainda, desobriga a chamada "boa escola" de lidar com algo que não sejam os saberes escolares, entendidos de uma maneira bastante reducionista.

\section{B. A escola é saudável e atua como uma escola promotora de saúde}

Embora não se tivesse solicitado dos sujeitos que explicitassem a sua percepção quanto à possível correlação entre o fato de uma escola ser de boa qualidade e/ ou ser saudável, vale a pena relatar como se posicionam a este respeito:

"Há escolas consideradas boas pela comunidade, mas que não têm nenhuma preocupação com a saúde, nem são saudáveis, nem promovem a saúde de ninguém. $O$ professor vai lá e faz o seu trabalho. Para que ela seja saudável, ela tem que brilhar e o profissional tem que dar a sua alma, a sua emoção. Ou eu vou e me dou por inteiro ou eu não consigo fazer uma escola saudável. Ela não só ensina, mas ensina para a vida...ela não fala só do que é bom, mas oferece um bom ambiente para o aluno e para todos. Tem escola que é boa no sentido tradicional - tem fama, faz o aluno entrar no vestibular, mas não promove a saúde dos alunos e nem é agradável por dentro, nem é saudável, como estamos dizendo. Já vi escola que é considerada boa que não está nem ai com a qualidade de vida dos alunos e que não tem este clima agradável daqui".

De início, parece claro que se reconhece que qualquer escola precisa assegurar que se estabeleça a dinâmica necessária entre ensino e aprendizagem, ou seja, a escola precisa ensinar e o aluno precisa aprender. No entanto, quando se trata da percepção do que é uma escola saudável, outros pontos são agregados a este:

- oferta de um ambiente saudável para o aluno e para todos; 
- garantia de ensino para a vida;

- oferta de referências quanto à qualidade de espaços e ambientes escolares;

- promoção da saúde.

$\mathrm{Na}$ tentativa de buscar o melhor entendimento dessas representações, vale a pena recorrer a novo trecho do discurso do sujeito coletivo, agora sobre " promoção da saúde":

"O papel nosso é importante porque temos que promover a saúde dos alunos. No ano passado, fizemos um projeto de obesidade da criança, pois começamos a ter este problema. No refeitório, as crianças aprendem a comer, a ter hábitos saudáveis, a não comer exagerado. Precisamos também garantir o conteúdo da saúde ... fazer sempre a teoria casada com a prática. (...) se aqui o ambiente é saudável, estamos oferecendo um exemplo para as crianças. Temos que encaminhar também os alunos que precisam de atendimento ... encaminhamos para o postinho (...). Era mais fácil quando a gente tinha dois dentistas da prefeitura aqui, mas não podemos ficar lamentando".

Ao mesmo tempo que este depoimento esclarece qual a percepção da escola sobre "promoção de saúde" e fornece pistas sobre o que seria " educar para a vida", deixa claro que se reconhece a conveniência da oferta de serviços de saúde, na própria escola, e a opção adotada quando esta não é a diretriz das políticas públicas: o encaminhamento dos alunos ao sistema público de saúde.

Se estas são as representações da escola, é interessante compará-las com os referenciais da Organização Pan-americana de Saúde sobre a atuação das escolas promotoras de saúde. Segundo estes referenciais, tais escolas devem assegurar ações que cubram três diferentes componentes, intimamente relacionados:

- a oferta de serviços de saúde na escola;

- a instalação de ambientes escolares saudáveis e, finalmente;

- a oferta de Educação em saúde.

O conteúdo dos discursos não deixa dúvidas de que há uma razcável aderência entre a fala da escola e as indicações da Organização Pan-americana de Saúde, sugerindo uma boa percepção quanto à natureza das ações a serem efetivamente desempenhadas por uma escola saudável e, ainda, quanto à necessária articulação entre estas ações. Em se tratando da "instalação de ambientes saudáveis", é interessante verificar que, além do 
reconhecimento de que "não dá para estudar dentro de uma lata de lixo", o discurso deixa implícito que a arquitetura escolar, mais especificamente, os espaços escolares, em geral, são dotados de significados e transmitem uma importante quantidade de estímulos, conteúdos e valores.

A este respeito, vale a pena retomar trecho de um depoimento, agora referindo-se a um dos espaços físicos da escola.

“O pátio da escola é uma maravilha ...espaçoso, arejado, coberto, cercado por flores ....parece aquela definição de ilha ...em vez de água por todos os lados, são flores por todos os lados. Há bebedouros muito higiênicos e nós mandamos examinar a qualidade da água que eles bebem. Os alunos aprendem também aqui - lições de saúde, de higiene, de bons modos".

Não resta dúvida de que se fala de um currículo oculto, para o qual não se contrata nenhuma professora em especial. Expressa-se a perspectiva de que o espaço em questão - no caso, o pátio escolar - é, por si mesmo, um ...programa, aliás, como diz ESCOLANO, "uma espécie de discurso que institui na sua materialidade um sistema de valores, como os de ordem e disciplina, marcos para a aprendizagem sensorial e motora e toda uma semiologia que cobre símbolos estéticos, culturais e ideológicos". (FRAGO 1998). E a representação que brota do discurso dos sujeitos é portadora desta genuina clareza: os espaços escolares representam uma forma silenciosa de ensino. Na prática, o grupo se vê refém desta clareza, levantando a bandeira de que a "sua" escola é limpa, bonita, organizada e que vale a pena conservá-la assim, inclusive como garantia do impacto positivo desses aspectos na sala de aula e no seu clima geral . A este respeito, observem-se os seguintes trechos do discurso coletivo:

"O prédio e a conservação dele deixam qualquer outra escola com inveja. Muito verde, muita flor, muita ordem, muita limpeza... também muito trabalho sério e pessoas felizes aqui dentro"

"Esta escola é muito boa. Para começar, é limpa, bem construida, arejada, arborizada. Dá gosto de andar por aqui ...ela é esteticamente bonita e tem até gente que fica perguntando se ela é mesmo uma escola estadual "

"Em relação ao espaço físico é uma escola arborizada, limpa, conservada e isto ajuda bastante. Quando o aluno vê a escola limpa, organizada, isto ajuda muito " 
melhora até a maneira como ele age na sala de aula. Isto ajuda muito na relação com o aluno e no coletivo"

Não há dúvida, portanto, que o discurso da escola dá indicações seguras de que as posições explicitadas são absolutamente favoráveis e coerentes à criação de espaços saudáveis no interior da escola e à oferta de serviços de saúde, mediante encaminhamento, o que aproxima e muito este discurso ao padrão de escola saudável explicitado pela Organização Pan-americana de Saúde. Quanto à terceira exigência apontada por esta organização - a oferta de Educação em saúde - fica a dúvida: qual o grau de proximidade entre este componente e a abordagem de "conteúdos" de saúde, referida no discurso do sujeito coletivo?

Para elucidar este aspecto, vale a pena conferir as diretrizes da Organização Panamericana de Saúde para a implementação da Educação em saúde, segundo as quais a escola deve:

- abordar a saúde em termos globais, segundo a ótica de inter-relação entre os seus fatores individuais, ambientais, sócio-econômicos e coletivos;

- esgotar todas as oportunidades educativas - formais e informais - para promover, melhorar, manter e recuperar a saúde;

- analisar criticamente as diferentes mensagens de saúde que influenciam as crianças e os jovens;

- comprometer-se com a conscientização de crianças e jovens para atuarem de maneira a favorecer a manutenção e a promoção da saúde integral e coletiva;

- construir continuadamente uma convivência solidária em prol da vida e dos direitos humanos.

Embora não se pretenda fazer uma referência exaustiva a cada um destes pontos, é inegável que, mais uma vez, o discurso do sujeito coletivo se aproxima bastante destes padrões. No que se refere à abordagem da saúde em termos globais, ainda que não tenha sido suficientemente explicito a este respeito, há indícios de que é este o paradigma perseguido pela escola que assim se posiciona: 
"A escola deve saber bem o que é saúde e como ensinar saúde .. se ela achar que é só ausência de doença, ela só vai trabalhar aquele pout-pourri de doenças, muito chato e só para a prova, não para a vida".

Com efeito, quando se afirma que a saúde não é apenas ausência de doença, fica implicito que não se pretende reduzir o seu entendimento à mera relação entre uma pessoa - doente ou candidato a doente - e um agente qualquer que possa lhe "provocar" uma doença. Este posicionamento emerge de uma outra maneira, quando um sujeito faz referência aos espaços nos quais os conhecimentos de saúde são trabalhados na escola:

“... a escola desenvolve um bom trabalho de saúde divulgando conhecimentos $e$ tudo o que é informação de saúde. Tenho percebido que isto acontece em todos os projetos que a escola trabalha, em vários componentes curriculares, na área de ciências, biologia, sociologia, nas relações humanas".

Também em Matemática, uma disciplina cujo ensino tem resistido a se render aos princípios da contextualização ${ }^{59}$, o tema da saúde é trabalhado numa perspectiva que não apenas a individual. É o que se pode observar no seguinte relato:

“(...) em Matemática não dá para trabalhar saúde ... ah...ia me esquecendo: na 8 " série trabalhei com taxa de mortalidade, indices de doenças, gráficos ...estas coisas. Não dá para incluir tudo, mas dá para trabalhar com dados sobre nutrição, oferta de alimentos".

Embora estas indicações sugiram que a escola busca abordar os conteúdos de saúde numa perspectiva que ultrapassa o seu enfoque individual, não há evidencias suficientemente fortes que possam sustentar a tese de que, na área da promoção da saúde, também é este o entendimento do grupo. Neste particular, a percepção explicitada é a de que se deva favorecer a manutenção e a promoção da saúde individual, sem que se toque na promoção da saúde coletiva ${ }^{60}$ :

\footnotetext{
59 Sào inúmeros os estudos que apontam a necessidade de que o ensino da Matemática contemple os desafios que o cidadão é compelido a resolver no seu cotidiano, entre os quais o de "ler" gráficos e decodificar tabelas, assegurando-lhe, ainda, condições para que analise qualitativamente tais dados. No entanto, nem sempre se tem conseguido imprimir esta direçào e a Matemática ainda se constitui no "bicho papão" para muitos alunos e escolas.

${ }^{60}$ Nåo há, salvo melhor juizo, nenhuma referência mais explicita nem à saúde da comunidade escolar, nem a saude em termos populacionais.
} 
“... a escola tenta promover a saúde dos alunos... trabalha conteúdos e oferece oportunidades para o aluno sinta, na prática, o que significa um ambiente saudável, uma vida saudável".

Quanto à conscientização, propriamente dita, ela aparece atrelada à necessidade de conservação da escola, sem que se tenha explicitado uma relação mais concreta entre este fato e a promoção da saúde coletiva. Num trecho do discurso do sujeito coletivo, o grupo assim se pronuncia:

"Nossos alunos sabem que têm que conservar a escola, pois ela é de todos e vai ser um dia dos filhos deles. Um dia, dois alunos quebraram alguns vasos - nós não brigamos - chamamos a família, explicamos que aquilo era patrimônio nosso - e eles acertaram tudo. (...) É um trabalho incansável. (...) Tem que conscientizar que a escola é nossa e nós temos que zelar por ela...(...) a escola é de todos e vai ser um dia dos filhos deles.

Outros trechos do discurso do sujeito coletivo permitem reforçar a leitura que a escola tem a percepção de que é seu papel esgotar todas as oportunidades educativas para promover, melhorar, manter e recuperar a saúde dos alunos. Ainda que o discurso não seja explícito, merece destaque o seguinte trecho:

"Levo a sério o meu trabalho, encaro o meu aluno como uma pessoa, me empenho para saber o que ele já sabe e fazer ele crescer... eles se valorizam mais $e$ viram gente grande, boa, saudável, que sabe o que quer, que sabe fazer, que sabe conseguir as coisas. Se todos os professores fizerem assim acho que é muito. Vi um dado que só o fato de uma pessoa saber ler já aumenta o tempo de vida dela... se a escola faz mais ainda, se preocupa com a saúde de dentro e de fora da escola, melhora ainda mais".

Constatadas estas aproximações entre o discurso do sujeito coletivo e as exigências colocadas pela Organização Pan-americana de Saúde quanto à abordagem da Educação em saúde, merece registro o fato de que o grupo não fez nenhuma referência quanto à necessidade de que a escola se empenhe em analisar criticamente as diferentes mensagens de saúde que influenciam as crianças e os jovens. Já quanto ao entendimento de que é seu papel contribuir para "construir continuadamente uma convivência solidária 
em prol da vida e dos direitos humanos", vale a pena transcrever um outro trecho do discurso do sujeito coletivo:

"Os professores daqui se preocupam com a comunidade e todo mundo pensa no bem estar de todos. Não só do corpo docente, mas também dos funcionários, dos alunos, em todos os aspectos. Não só na ausência da saúde ou na doença, mas no estado social das pessoas que se encontram na escola e na comunidade".

Num outro trecho do discurso do sujeito coletivo, o grupo afirma:

"Acho que o papel da escola é trabalhar também com valores Aqui, por exemplo, nós trabalhamos com projetos nas aulas eventuais : cidadania e participação. nas $5^{a s}$. e $6^{a s}$. séries, preconceito e solidariedade, nas $7^{a s}$. e $8^{\text {as }}$. séries; sexualidade e preconceito, nal $1^{a}$ série do Ensino Médio, ética, no $2^{\circ}$ ano e diversidade cultural, na $3^{a}$ série. Estas questões envolvem valores e eles precisam ser discutidos" ${ }^{61}$

Embora a alusão seja, aqui, quanto aos conteúdos abordados, há outras indicações de que a escola não trabalha apenas com a dimensão " falar sobre" tais temas, mas estimula que as práticas sociais dos alunos sejam impregnadas de muitos destes valores. Pelo menos é que se pode depreender deste trecho :

“(...) . percebi que meus alunos não estão desenvolvendo certos valores - e achei necessário fazer isto. Alguma coisa para desenvolver a solidariedade, - vamos ajudar o seu coleguinha, vamos ajudar o outro. Se a gente faz isto de pequeno, quem ajuda não vai se considerar um caxias ou um idiola. Quem precisa de ajuda, vai saber solicitar a ajuda".

Constatada a aproximação entre as percepções dos sujeitos e as exigências da Organização Pan-americana para que uma escola seja saudável, pode-se admitir que sejam igualmente muito próximas do que dispõem os parâmetros curriculares nacionais, uma vez que o documento oficial do Ministério da Educação foi bastante fiel aos principios daquela Organização.

\footnotetext{
${ }^{\circ}$ Observe-se que o grupo faz referencia aos temas transversais abordados pelos paràmetros curriculares nacionais. documentos enviados pelo Ministerio da Educação para a residencia de cada professor. Considerando-se que a Secretaria de Educação do Estado de São Paulo não organizou nenhuma capacitaçåo sobre os temas transversais. tem-se um indicio claro de que talvez a estratégia do Ministério possa ser repetida com eficiència na divulgaçào de materiais similares.
} 
Com efeito, uma leitura razoavelmente atenta das idéias gerais e dos discursos sociais coletivos permite verificar que as percepções da escola coincidem com as caracteristicas das escolas que, segundo os parâmetros curriculares nacionais de saúde, contribuem para a promoção da saúde. A julgar pelos discursos do sujeito coletivo, a escola:

- tem uma visão ampla de todos os ambientes da escola, provendo um ambiente saudável e que favorece a aprendizagem, não só nas salas de aula, mas também nas áreas destinadas ao recreio, nos banheiros, nos espaços em que se prepara e é servida a merenda, enfim, em todo o prédio escolar;

- concede importância à estética do ambiente físico da escola, assim como ao efeito psicológico direto que ele tem sobre professores e alunos;

- está fundamentada num modelo de saúde que inclui a interação dos aspectos físicos, psíquicos, sócio-culturais e ambientais;

- promove a participação ativa de alunos e alunas;

- reconhece a necessidade de incluir temas de saúde nas diferentes áreas curriculares;

- entende que o desenvolvimento da auto-estima e da autonomia pessoal são fundamentais para a promoção da saúde;

- valoriza a promoção da saúde para todos os que nela estudam e trabalham:

- tem uma boa visão dos serviços de saúde que podem atender ao escolar;

- reforça o desenvolvimento de estilos saudáveis de vida e oferece opções viáveis para a prática de ações que promovem a saúde;

- favorece a participação ativa dos educadores e da comunidade na elaboração do projeto pedagógico da escola.

Há também uma aderência entre a percepção dos sujeitos sobre os motivos que a tornam uma boa escola $\mathrm{e}$ as indicações das pesquisas educacionais nesta área. em especial. aquela referida neste documento? Ao que tudo indica. sim. 


\section{A escola é, de fato, uma boa escola}

Conforme já se adiantou aqui, as percepções do grupo quanto aos motivos pelos quais a escola é boa e saudável foram basicamente os mesmos. Desta maneira, neste espaço serão discutidos, em especial, os argumentos que coincidem com as características explicitadas no Capítulo I deste trabalho, referentes às conclusões da pesquisa da Fundação Carlos Chagas sobre os indicadores que estão relacionados a uma escola de boa qualidade.

De maneira geral, tais escolas caracterizam-se pelo fato de que suas instalações são limpas e bem utilizadas, aliás, um fato facilmente verificável mediante a leitura do discurso do sujeito coletivo. Além disso, pais, alunos e pessoas da comunidade são tratados com deferência pela escola, situação que pode ser considerada a da escola, a julgar pela alegada proximidade entre ela e a comunidade e pelo fato de que esta ocupa regularmente os espaços escolares, nos finais de semana, para realização de atividades culturais e esportivas, entre outras. A esse respeito, os sujeitos afirmam que:

"A comunidade participa muito - ela é nossa parceira de todas as horas. A escola tem um excelente relacionamento com a comunidade. $\dot{E}$ raro o final de semana que a escola não está aberta ... a comunidade se responsabiliza por tudo e nunca tivemos nenhum problema. A escola conta com eles e eles com a escola - a escola é nossa nós somos a comunidade".

Quanto à atmosfera ou clima organizacional, destacam-se como escolas de qualidade aquelas que têm um projeto claramente definido, situação que já foi devidamente documentada nos itens anteriores, Além disso, nestas escolas, o relacionamento entre os profissionais é cordial e respeitoso. Mais uma vez, as percepções dos sujeitos dão conta de que estas são características da sua escola:

"Esta escola me marcou muito. Eu me adaptei com os colegas e as colegas. A diferença é da água para o vinho. Nas outras escolas, falta diálogo, falta amizade, falta coleguismo, falta organizaçào. Aqui. as pessoas estão bem entrosadas e (....) as pessoas não se entrosam apenas para melhorar a aula, mas também para deixar o clima daqui legal.(...) Há muito coleguismo aqui (...) as pessoas se respeitam muito".

A uma boa escola não basta ter apenas um clima respeitoso e de amizade; segundo as indicações. é necessário que os professores tenham uma linha comum de 
trabalho, o que parece acontecer na escola, segundo as representações dos sujeitos que afirmam que esse tipo de decisão é tomado em reuniões coletivas, ficando o grupo responsável pela cobrança dos que dela se desviarem. Sobre este aspecto, os sujeitos declaram:

"Precisa ser um trabalho de todos - de dentro e de fora da escola. Hoje mesmo, nas horas de trabalho pedagógico, nós discutimos uma postura conjunta do corpo docente - dissemos que quem destoar, o grupo vai cobrar".

Nas escolas de boa qualidade, os pais e mães são envolvidos ativamente no acompanhamento do projeto da escola e são parceiros na manutenção de um bom rendimento escolar. A este respeito, os discursos dos sujeitos são abundantes e não deixam nenhuma dúvida quanto à participação dos pais como parceiros na educação escolar de seus filhos, bem como da clareza que a escola tem quanto a uma das barreiras que dificulta o acompanhamento mais direto da vida escolar dos filhos e filhas: a incompatibilidade entre o horário das reuniões agendadas pela escola e o horário de trabalho dos pais e mães, em especial, no caso de alunos que freqüentam o periodo noturno. Para ultrapassá-la, observa-se que a escola montou um esquema rotineiro de comunicação entre a equipe escolar e os pais e mães dos alunos.

Uma outra caracteristica das boas escolas é transformar salas de aula e pátios em ambientes de aprendizagem - e as percepções dos sujeitos deixam bastante claro que esta é a situação de sua escola.

No que se refere ao plano escolar, o conteúdo discursivo do grupo não deixa dúvidas: é conhecido pela direção, corpo docente e comunidade, sendo considerado como o registro das intenções da escola que se pretende firmar como uma boa escola. A este respeito, o grupo assim se posiciona:

"Precisa ter um projeto muito bem definido. De avançar, para que os professores, os funcionários, a direção, a coordenação, os alunos e a comunidade consigam definir prioridades - atender bem o aluno, fazê-lo aprender. construir uma escola que seja uma extensão do lar. Há necessidade de caminhar junto com a comunidade, mais do que qualquer outra coisa. Tem que levantar todos os problemas. mas saber o que atacar em primeiro lugar...senão. fica tudo ruim". 
Ao mesmo tempo que o discurso é denotativo de que a escola tem um projeto bem definido, deixa explícito que o ponto fulcral deste projeto é assegurar a aprendizagem do aluno, uma das expressões que caracterizam a chamada " cultura do sucesso escolar".

Por outro lado, há bastante clareza que o essencial da atividade da direção da escola é liderar o processo educativo aí desenvolvido, subordinando suas atividades administrativas e burocráticas à dimensão pedagógica, conforme se pode perceber no seguinte discurso:

"Nas outras escolas, o diretor não fica oito horas na escola - ele trabalha em dois lugares e aparece ou só para abrir ou só para fechar a escola. O que mais sobrecarrega a estrutura é a parte burocrática - e quando o diretor fica pouco tempo na escola, concentra-se na burocracia. O coordenador faz papel de porteiro, de secretário. Aqui não. A diretora está presente o tempo todo - é comprometida, sabe o caso de cada aluno, conhece todos os professores - o vice diretor apoia o diretor e o trabalho é bem distribuido, o coordenador faz um bom trabalho pedagógico".

Nas boas escolas, o tempo destinado ao trabalho coletivo é utilizado para a realização de atividades de apoio ao desempenho dos professores em sala de aula e para melhorar o desempenho geral da escola, situação que pode ser facilmente reconhecida no seguinte trecho do discurso coletivo:

“(...) as nossas horas de trabalho coletivo viram horas de capacitação, pois as pessoas trocam experiências, aprendem uns com os outros. Assim, muita gente perde o medo de tentar fazer alguma coisa boa que já deu certo, elas crescem profissionalmente e a equipe fica mais fortalecida. As aulas ficam mais ricas e todos ganhamos com isso".

No que se refere à atuação dos professores, não há dúvida de que a percepção dos sujeitos a este respeito são absolutamente coincidentes com as características apontadas pela pesquisa da Fundação Carlos Chagas. De maneira geral, os professores acreditam que podem ensinar. utilizam materiais e recursos didáticos diversificados em suas aulas, dominam uma metodologia de trabalho e participam de cursos de capacitação e orientação técnica.

No entanto, a despeito de que fica implícito no discurso social coletivo que a escola vem impregnando o seu trabalho de ações cotidianas diretamente relacionadas a 
exercicio da cidadania, por vezes se tem a idéia de que ela talvez não tenha se dado conta disto, qualificando sua ação como uma espécie de "preparação para o futuro", de "preparação para a cidadania". Com efeito, nos relatos de situações nas quais os alunos exercitam a solidariedade ("auxiliam o colega que tem qualquer tipo de dificuldade") e o respeito pelo outro ("os grandes não atropelam os pequenos"), a alegação é de que a escola está "preparando os alunos para o futuro", ou seja, uma vida futura na qual a cidadania será exercida. $E$, salvo melhor juízo, a escola pode não ter suficiente clareza de que está criando as circunstâncias necessárias para que, na ação mesma da educação, os educadores e os educandos exercitem principios democráticos ou, em outras palavras, exercitem plenamente a sua cidadania. Ou seja, os alunos não estão sendo preparados para se tornarem futuros cidadãos; ao contrário, eles estão (re)construindo diariamente esta cidadania no interior da escola. No momento em que a equipe escolar se lança à tarefa de mudar a escola para melhor, já está interferindo na realidade, já está tratando concretamente das questões mais amplas de respeito ao outro, do auto-cuidado, da responsabilidade, da participação e da estreita articulação com a comunidade.

Se é esta a identidade explicitada pela escola - um "lugar" de cidadania - como o grupo conta a sua história e quais os ingredientes desta aventura de se tornar, a cada dia, cada vez mais afinada com o bom atendimento do aluno?

\section{Fatores associados à atual identidade da escola}

Uma retrospectiva sobre como o discurso do sujeito coletivo relata a caminhada da escola na direçâo a se tornar o que é hoje. exige a retomada de alguns pontos. $\mathrm{O}$ primeiro deles diz respeito ao fato de que, para o grupo. esta é uma escola que tem raizes, que tem tradição, que tem uma história conhecida por todos e isto, de alguma forma, desempenha um efeito aglutinador das vontades, interesses e ações de todos: equipe escolar, alunos e pais de alunos.

A este respeito, vale a pena recorrer a um trecho dos depoimentos, quando o sujeito discorre sobre porque entende que a escola é uma boa escola:

" (...) esta escola é de descendentes de um grupo de italianos e mesmo que a clientela tenha variado eles tém conseguido manter essa coisa do inicio. A clientela á 
diferente do resto do municipio - há moradores mais antigos e os que chegam vão aprendendo com eles. É uma escola antiga que já tem uma história e isto ajuda muito! (...) mesmo com as mudanças na educação, a comunidade daqui sabe muito bem o que quer da escola e influencia o que acontece aqui dentro".

Segundo esta percepção, o movimento de criação da escola nasce da própria comunidade: a escola não foi criada pelo poder público para atender às demandas locais, mas pelos descendentes de italianos que fundaram uma tecelagem na região. Neste particular, é digna de nota a expressão: "esta escola é de descendentes de um grupo de italianos"!

Alguns elementos se somam a este, em especial a " vontade de fazer", referida tanto em termos individuais ("cada um tem que fazer a sua parte") quanto em termos do grupo ("precisa de vontade coletiva"). Tome-se como referência o seguinte depoimento:

“ (...) precisa ter vontade de fazer ...precisa acreditar que se pode fazer ..precisa de muita paixão para isto. (...) A equipe precisa querer fazer, precisa ter coragem de se responsabilizar pela melhoria da qualidade da escola, precisa arregaçar as mangas $e$ fazer".

Esta vontade precisa ser estimulada e canalizada, somando-se à vontade de fazer dos pais, mães e alunos; por sua vez, os esforços coletivos devem convergir para que a escola possa ensinar bem - numa perspectiva cidadã. Para isto, a escola precisa contar com uma direção presente, comprometida, que eleve a auto-estima dos professores, que estabeleça metas, que crie as condições para a definição das prioridades de ação e mecanismos sistemáticos de acompanhamento e controle. Nas palavras dos sujeitos:

"(...) esta é uma escola que tem direção e isto em dois sentidos: a diretora vive aqui e sabe qual é o seu papel - faz este papel muito bem".

A parceria entre a escola e a comunidade é constante e percebida como condição sine qua non para o sucesso da escola, a tal ponto que se constrói a expressão " a escola é nossa...nós somos a comunidade".

É necessário reforçar que esta parceria tem um objetivo muito claro. até porque este foi o sentido quase hegemônico dos discursos: melhorar a situação na sala de aula. tornar as aulas interessantes. estabelecer o diálogo entre os alunos e professores. fazer 
com que estes possam ensinar e aqueles possam aprender. Um dos depoimentos é emblemático desta percepção:

“ (...) a nossa preocupação tem que ser com o aluno. Nós temos que ter sempre isto presente, senão a gente se perde. Limpa a escola, compra materiais interessantes. faz passeios, mas nada que represente alguma coisa para o aluno. Se a escola muda e nada muda para melhor na sala de aula, acho que não adianta!".

Outros depoimentos explicitam as percepções do grupo sobre o que significa mudar a sala de aula "para melhor", percepções estas que podem ser facilmente consultadas no capítulo anterior ou, ainda, no Anexo 8. No entanto, não é demais insistir que, para o grupo, a escola toda é uma grande sala de aula e os espaços, em geral, cumprem também uma função pedagógica, aliás como bem indica uma expressão relativa à utilização do pátio e do refeitório da escola: " os alunos aprendem também aqui - lições de saúde, de higiene, de bons modos".

A este respeito, vale a pena recorrer, mais uma vez, ao pensamento de FRAGO(1998), para quem a destinação de espaços específicos para as atividades de ensino - no caso, as salas de aula - tem contribuído para a entropia da educação escolar, em especial quando, no dizer do autor, "se esquece que se opera não com materiais inorgânicos, mas sim com seres humanos (...) e o lugar construído torna-se um sistema fechado, não flexível nem adaptável, no qual as necessidades de apropriação territorial do ser humano e de configuração de espaços pessoais e alheios. comuns e compartilhados, tornam-se inviáveis".

Se é esta a regra na utilização dos espaços escolares - e este não é o caso desta escola - o aprisionamento das atividades educativas ao espaço das salas de aula acaba por reduzir o âmbito destas atividades às opções "compatíveis" com os rituais que a tradição escolar entende que possam ser ai cumpridos. Além disso. o "lugar" escola passa a perder muito do sentido que os seus "habitantes" Ihe confeririam, pois se estabelece uma fronteira muito rigida entre o que é educação ( o de "dentro" da sala de aula") e o que nào é educação ( o de "fora" da sala de aula. ou seja. o que acontece nos corredores, no pátio, nos banheiros. na sala dos professores. na quadra. no refeitório. na comunidade, no entorno da escola e na vida. em geral). 
A julgar pelo discurso do sujeito coletivo. a escola já ultrapassou este estágio, derrubou esta fronteira entre o "de dentro" e o "de fora" da sala de aula e o espaço escolar pôde ser construido como "lugar". de modo a que "não se restrinja a diversidade de usos ou sua adaptação a circunstâncias diferentes"( FRAGO 1998).

É óbvio que a simples queda desta fronteira não determina a qualidade final do espaço (re)construído: um espaço frio, mecânico ou, ao contrário, um espaço quente e cheio de vida. Aliás, esta segunda possibilidade é a percepção que o grupo tem a respeito de sua escola, a julgar pela utilização freqüente de expressões "é gostosa". " tem muita vida", "tem muito calor humano", " tem cara da casa da gente", ao se referir sobre os espaços da escola.

Ao que tudo indica, a escola se aliou à comunidade e vem desempenhando a tarefa continuada de (re)desenhar um "lugar" que seja coletivo, reconhecido, valorizado e "protegido" por todos, numa autêntica "pedagogização" de todos os espaços da escola. E é óbvio que todos ganham com isso - e sabem que ganham - , pois se tem na escola um autêntico espaço para a ...educação. ${ }^{62}$

Com efeito, o discurso social coletivo registra expressões do tipo "ganha o aluno, ganha o professor, ganha a escola" e , ainda. " aqui as pessoas são felizes". "esta escola me marcou muito", " eu sou gente aqui" e outras inúmeras expressōes de apreço pela escola. Esta satisfação e compromisso com a continuidade do trabalho, claramente expressas em vários pontos do discurso social coletivo. são dialeticamente acompanhadas pelo receio de que "as coisas mudem".

\section{F. O fantasma da descontinuidade}

De certa forma, um dos fantasmas explicitados no discurso social coletivo tem a ver com uma caracteristica tradicional do setor educacional: a cada administração, sâo abandonados e/ou substituidos programas e/ou projetos iniciados na gestão anterior e

\footnotetext{
"Pode parecer uma obviedade afirmar que o rompimento das fronteiras entre o "de dentro" eo "de fora" da sala de aula seja um passo para que a escola. como um todo. assuma seu compromisso com a educação. pois salvo melhor juizo, esta e a sua especificidade. No entanto, nào é que se observa. em geral.
} 
estas rupturas nem sempre obedecem a critérios técnicos e políticos - no sentido de buscar o bem público.

Pois o grupo da escola teme que o atual estágio do trabalho possa sofrer prejuízos, caso haja alterações no que talvez considerem um de seus pilares: a composição de uma equipe básica que, de certa forma, dá sustentação às ações dos demais profissionais.

“ (...) a gente sempre fica com medo do que vai acontecer no próximo ano, se a equipe vai continuar na escola. A educação passa por mudanças todo ano e, nisso, todo trabalho é quebrado e você vai de novo colocando aquele tijolinho. Ai, chega no final do ano - quebra. Sempre ficam algumas pessoas. E você consegue construir. E dá uma quebrada, mas você vai moldando de novo. Mas podia ser mais fácil".

Segundo os sujeitos, também a direção ${ }^{63}$ não estaria a salvo das mudanças patrocinadas pela Secretaria de Educação:

“A escola $\dot{e}$ formada por pessoas e ela vai ser saudável dependendo se as pessoas que formam ela estão agindo neste objetivo. Por exemplo, se mudar a direção, se o diretor não tem mais este objetivo, se os professores não colaborarem, uma escola que é considerada saudável , no outro ano pode deixar de ser saudável".

Um outro medo que flui de duas falas diz respeito ao sistema de progressão continuada $^{64}$, previsto na legislação federal e implantado pelo Conselho Estadual de Educação do Estado de São Paulo. Ainda que o próprio sujeito explicite que as pessoas "não entendem o espirito da coisa", afirma que isto pode deixar "as pessoas displicentes porque acham que o Estado quer aprovar todo mundo".

No entanto, não é a política educacional ou, ainda, a gestão do sistema, as únicas fontes geradoras do sentimento que a continuidade do bom trabalho realizado pela escola pode ser ameaçada. Dois dos sujeitos expressam o temor de que o tempo familiar

\footnotetext{
${ }^{63}$ No Estado de São Paulo, o cargo de Diretor de Escola é preenchido por concurso de títulos e provas. Até o último concurso de ingresso, exigia-se do postulante a Licenciatura em Pedagogia, com Habilitação em Administração Escolar, além de très anos de exercicio efetivo no magistério oficial.

${ }^{64} \mathrm{O}$ sistema de progressão continuada é um regime de organização escolar que tem como princípio a flexibilidade na organização do ensino e o respeito ao ritmo de aprendizagem do aluno. No Estado de São Paulo, o Conselho Estadual de Educação instituiu este regime no ensino fundamental, por meio da Deliberação CEE N". 9/97, homologada pela Secretaria de Estado da Educação (Resolução SE, de 4/8/97) Este regime estabelece dois ciclos no ensino fundamental, cada qual com a duração de quatro anos. A avaliação com efeito de retençào é realizada entre os dois ciclos e ao final do último.
} 
estas rupturas nem sempre obedecem a critérios técnicos e politicos - no sentido de buscar o bem público.

Pois o grupo da escola teme que o atual estágio do trabalho possa sofrer prejuizos, caso haja alterações no que talvez considerem um de seus pilares: a composição de uma equipe básica que, de certa forma, dá sustentação às ações dos demais profissionais.

“ (...) a gente sempre fica com medo do que vai acontecer no próximo ano, se a equipe vai continuar na escola. A educação passa por mudanças todo ano e, nisso, todo trabalho é quebrado e você vai de novo colocando aquele tijolinho. Ai, chega no final do ano - quebra. Sempre ficam algumas pessoas. E você consegue construir. E dá uma quebrada, mas você vai moldando de nov'o. Mas podia ser mais fácil".

Segundo os sujeitos. também a direção ${ }^{63}$ não estaria a salvo das mudanças patrocinadas pela Secretaria de Educação:

"A escola é formada por pessoas e ela vai ser saudável dependendo se as pessoas que formam ela estão agindo neste objetivo. Por exemplo, se mudar a direção, se o diretor não tem mais este objetivo, se os professores não colaborarem, uma escola que é considerada saudável, no outro ano pode deixar de ser saudável".

Um outro medo que flui de duas falas diz respeito ao sistema de progressão continuada $^{64}$, previsto na legislação federal e implantado pelo Conselho Estadual de Educação do Estado de São Paulo. Ainda que o próprio sujeito explicite que as pessoas "não entendem o espirito da coisa", afirma que isto pode deixar "as pessoas displicentes porque acham que o Estado quer aprovar todo mundo".

No entanto, não é a política educacional ou, ainda, a gestão do sistema, as únicas fontes geradoras do sentimento que a continuidade do bom trabalho realizado pela escola pode ser ameaçada. Dois dos sujeitos expressam o temor de que o tempo familiar

\footnotetext{
${ }^{63}$ No Estado de São Paulo, o cargo de Diretor de Escola é preenchido por concurso de títulos e provas. Até o último concurso de ingresso, exigia-se do postulante a Licenciatura em Pedagogia, com Habilitação em Administraçào Escolar, além de très anos de exercicio efetivo no magistério oficial.

ot O sistema de progressảo continuada é um regime de organização escolar que tem como principio a flexibilidade na organizaçăo do ensino e o respeito ao ritmo de aprendizagem do aluno. No Estado de Sào Paulo. o Conselho Estadual de Educação instituiu este regime no ensino fundamental, por meio da Deliberação CEE N. 9/97. homologada pela Secretaria de Estado da Educação (Resolução SE, de 4/8/97) Este regime estabelece dois ciclos no ensino fundamental, cada qual com a duração de quatro anos. A avaliaçåo com efeito de retençào é realizada entre os dois ciclos e ao final do último.
} 


\section{Considerações finais}

Escola saudável : a palavra é... 


\section{CONSIDERAÇÕES FINAIS ESCOLA SAUdÁVEL A PALAVRA É...}

A despeito de que se tenha praticamente esgotado todas as considerações referentes à investigação realizada, não se quer perder a oportunidade de registrar alguns pontos que ficaram bastante óbvios durante sua realização.

Temos muito que avançar para que todas as escolas brasileiras possam oferecer ensino de qualidade à população. Da mesma maneira, ainda estamos distantes da situação ideal em que todas as escolas possam se constituir em autênticos pólos de promoção da saúde. No entanto, estas duas questões articulam-se num único desafio, pelo menos segundo o que se pode observar das percepções da escola investigada sobre o que é uma "escola promotora de saúde", bastante próximas do que consideram como uma "escola de boa qualidade".

Caminhariam as percepções dos que atuam na área da Educação em saúde - por vezes, muito mais ligados à área da saúde e ao ensino superior - nesta mesma direção? Tais profissionais têm clareza que o caminho da melhoria da qualidade de ensino - nos termos em que esta melhoria está sendo discutida na atualidade - pode ser também uma via para a promoção da saúde? Em outras palavras, a quantas anda a fronteira entre a educação e a saúde? Entre a educação básica e o ensino superior? Entre os que "pensam" as reformas - estejam eles nos gabinetes dos Ministérios ou Secretarias da Educação e da Saúde ou, ainda, nas Universidades e/ou organismos internacionais - e os que fazem do dia-a-dia da educação a sua vida?

Particularmente não há como responder a estas indagações, nem esta era a intenção ao levantá-las. No entanto, parece indispensável conferir o entendimento que cada uma destas partes tem sobre o que significa hoje ser uma escola promotora de saúde, até para entender, mapear e lidar melhor com as prováveis resistências das escolas a propostas que caminhem nesta direção. Afinal. o engajamento das escolas na cultura do sucesso escolar é muito recente na escola brasileira é é perfeitamente compreensivel que aquelas que se tenham deixado seduzir por este paradigma e já 
colhem resultados de seu trabalho, sintam-se razoavelmente ameaçadas por outras novas propostas que possam representar algum tipo de risco ao caminho já percorrido.

De qualquer forma, os resultados desta investigação são alvissareiros: ao mesmo tempo que a escola caminha para ser uma escola de boa qualidade, vai agregando muitas das condições e circunstâncias que a qualificarão, igualmente, para ser uma autêntica escola promotora de saúde. E, a julgar pelas representações da escola investigada - um autêntica boa escola e uma escola que caminha a passos largos para a sua vocação de ser uma escola promotora de saúde - há algumas expressões que são bastante representativas da sua luta diária e podem ser reconhecidas pelas demais escolas que, pouco a pouco, seguem pelo mesmo caminho de conferir densidade à educação brasileira, no sentido de que se tome, finalmente, o partido da população que, felizmente, toma a escola de assalto - e não pode ser dela expulsa, nem receber uma educação de segunda categoria.

Esta investigação é encerrada com algumas destas expressões que, salvo melhor juízo, confirmam o título desta tese- "quem sabe, faz a hora" :

“ Esta escola é muito saudável. Ela é organizada ...tem que ser limpa, tem que funcionar, tem que fazer o seu papel de escola conseguir ensinar"
"Tem que ter uma equipe integrada ...que sabe o que tem que fazer ...tem que estar afinada com a comunidade". "A equipe precisa querer fazer ...precisa ter coragem de se responsabilizar pela mellioria da qualidade da escola...precisa arregaçar as mangas e fazer"

“ (...) a direção estimula os professores e faz a escola andar. A direção desta escola sempre eleva a auto-estima dos professores"
"É uma escola saudável que tem um projeto pedagógico concreto...este projeto está muito preocupado com valores(...) morais, valores de aprendizagem, valores de conteúdo"

"Precisa ter um projeto muito bem definido. De avançar para que os professores, os funcionários, a direção, a coordenação, os alunos $e$ a comunidade consigam definir prioridades - atender bem o aluno, fazê-lo aprender, construir uma escola que seja uma extensão do lar. Caminhar junto com a comunidade, mais do que qualquer outra coisa. Tem que levantar todos os problemas, mas saber o que atacar em primeiro lugar...senão, fica tudo ruim".

"É raro o final de semana que a escola não está aberta ... a comunidade se responsabiliza por tudo e nunca tivemos nenhum problema. A escola conta com eles e eles com a escola - a escola é nossa...nós somos a comunidade" 
"Precisa ser um trabalho de todos - de dentro e de fora da escola. Hoje mesmo, nas horas de trabalho pedagógico, nós discutimos uma postura conjunta do corpo docente dissemos que quem destoar, o grupo vai cobrar. Temos que estabelecer o diálogo como regra ....conversar sempre, tornar a escola agradável".

"Acho que as pessoas têm um pouco de medo do novo ...eu tenho, pelo menos. Para a escola ser cada vez melhor $e$ mais saudavel, ela precisa perder este medo ...se cada um souber que o outro também tem medo, acho que já é um passo para a frente. $O$ novo rem que ser melhor do que $o$ velho ...ndo $\dot{\text { qualquer }}$ novo... a educação está cheia de modismos"

Precisa ter alguém que alavanque. Tem que reunir um grupo de força que tenha as mesmas ideias. A partir dal, $e$ questao de estabelecer combinaçסes, estabelecer as regras do novo jogo. Precisa de ter força de convencimento

"A escola é boa também porque tem bons professores. Eles ndo enxergam a escola como um emprego, mas também nao acham que isto é sacerdocio. Trabalhamos sério e merecemos nosso salário. Esta escola é assim. Somos respeitados pelos pais - nem todas as escolas são"

"A comunidade precisa comprar o projeto da escola - precisa ter respeito pela escola, por tudoprédio e funcionários. Aqui nảo tem professorinha. Tem professora. A gente já conquistou isto. $\dot{E}$ muito gostoso você ver o sell trabalho recomheridn"
"Para que uma escola seja boa e saudável ela precisa abrir suas portas para a comunidade precisa se abrir por dentro, aparar as arestas, formar um grupo que faça mesmo e convença os outros a tambem fazerem o mesmo. Mas se abrir para fora também - repito muito, pois se a escola não serve à comunidade, ela é depredada, roubada, invadida"

"Precisa de estimulo e de cobrança. O que você percebe que num ano falhou, no outro você procura consertar. $O$ que vocé viu que era bom, aumenta aquilo. Aquilo que você viu que era preciso ser feito, vocé chama alguém, pede ajuda. Se ndo for desse jeito, vendo cada passo, não dá"

"Precisa falar de higiene e estar numa escola limpa ...falar de escola saudável e estar estudando numa boa escola saudável"

"Para que a escola seja boa e saudavel, a nossa preocupaçåo tem que ser com o aluno. Nós temos que ter sempre isto presente, senão a gente se perde. Limpa a escola, compra materiais interessantes, faz passeios, mas nada que represente alguma coisa para o aluno. Se a escola muda e nada muda para melhor na sala de aula, acho que não adianta. Se o aluno se sente bem na escola, se a escola é limpa e bonita, se o professor dá uma aula boa, a escola será saudável"

"Meus filhos estudaram aqui, minha filha ainda estuda. Eu tenho interesse que a escola seja boa. Se não fosse boa e saudavel, quem colocaria os filhos para estudar aqui dentro?"

“...se a escola puser os alunos para fora da escola, a rua abraça. E quando a rua devolver este aluno para os pais, ele já estará marcado, com sequelas. Então nós temos que abraçar aqui, na escola. Não podemos soltar. A escola tem que ser interessante, o aluno tem que ser ouvido, tem que poder contar as suas experiências...Agora, se a gente abraçar e o pai solta, a rua abraça" 


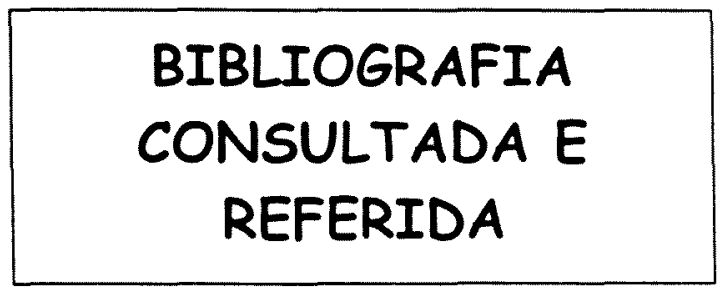




\section{BIBLIOGRAFIA CONSULTADA E REFERIDA}

Adorno R de CF, Castro AL de. O exercício da sensibilidade: pesquisa qualitativa e a saúde como qualidade. Rev Saúde e Sociedade 1994; 3 (2).

Berger PL e Luckmann T. A construção social da realidade, tratado de sociologia do conhecimento. $13^{\mathrm{a}}$ ed. Petrópolis: Ed.Vozes, 1996.

Chizzotti A.Pesquisa em ciências humanas e sociais. $2^{a}$ ed. São Paulo: Cortez Editora, 1995.

Collares CAL, Moisés MAA. Educação, saúde e formação de cidadania na escola. Educação e Sociedade 1989; (14) : 73 - 87.

Focesi E. Uma nova visão de saúde escolar e Educação em saúde na escola. Rev Bras. Saúde Esc. 1990; 2(1) : 19-21.

Frago AV, Escolano A. Curriculo, espaço e subjetividade: a arquitetura como programa. Rio de Janeiro : DP\&A, 1998.

Gil AC. Métodos e técnicas de pesquisa social. $7^{\text {a }}$ ed. São Paulo, Atlas, 1994.

Guareschi PA. Sem dinheiro não há salvação: ancorando o bem e o mal entre neopentecostais. In: Guareschi et al. Textos em representações sociais. $2^{\mathrm{a}}$ ed. Petrópolis: Editora Vozes, 1995.

Jovchelovitch S. Vivendo a vida com os outros: intersubjetividade, espaço público e representações sociais. In: Guareschi et al. Textos em representações sociais. $2^{\mathrm{a}}$ ed. Petrópolis: Editora Vozes, 1995.

Lefèvre F, Lefèvre AMC. Recuperando a fala do social. Série Monográfica n. 9, Universidade de São Paulo, Faculdade de Saúde Pública, 1998.

Lefèvre $\mathrm{F}$ et al. (Org.) $\mathrm{O}$ discurso do sujeito coletivo: uma abordagem metodológica em pesquisa qualitativa. Caxias do Sul: EDUCS, 2000.

Lefèvre F, Lefèvre AMC. A fala do social II. http://www. fsp.usp/ flefevre/ faladosocial.html, 2000.

Minayo MC. O desafio do conhecimento: pesquisa qualitativa em Saúde. $3^{\mathrm{a}}$ Ed. São Paulo - Rio de Janeiro: Hucitec-Abrasco, 1994.

Minayo MC. O conceito de representações sociais dentro da sociologia clássica In:

Textos em representações sociais. Petrópolis, Ed. Vozes, 1995. 
Ministério da Educação. Secretaria de Educação Fundamental. Parâmetros curriculares nacionais: introdução aos parâmetros nacionais. Brasilia, 1997(a).

Ministério da Educação. Secretaria de Educação Fundamental. Parâmetros curriculares nacionais: Ciências Naturais. Brasília, 1997(b).

Ministério da Educação. Secretaria de Educação Fundamental. Parâmetros curriculares nacionais: História e Geografia. Brasília, 1997(c).

Ministério da Educação. Secretaria de Educação Fundamental. Parâmetros curriculares nacionais: Educação Física. Brasília, 1997(d).

Ministério da Educação. Secretaria de Educação Fundamental. Parâmetros curriculares nacionais: apresentação dos temas transversais e Ética. Brasília, 1997(e).

Ministério da Educação. Secretaria de Educação Fundamental. Parâmetros curriculares nacionais: Meio ambiente e saúde. Brasília, 1997(f).

Ministério da Educação. Secretaria de Educação Fundamental. Parâmetros curriculares nacionais: Pluralidade cultural e Orientação Sexual. Brasília, 1997(g).

Ministério da Educação. Secretaria de Educação Fundamental. Parâmetros Curriculares Nacionais: Educação para a saúde, $3^{\circ}$ e $4^{\bullet}$ ciclos. Brasilia, 1997(h).

Ministério da Educação. Secretaria de Educação Fundamental. Parâmetros Curriculares Nacionais: Meio Ambiente, $\mathbf{3}^{\mathbf{b}} \mathbf{4}^{\circ}$ ciclos. Brasília, 1997(i).

Ministério da Educação. Secretaria de Educação Fundamental. Parâmetros Curriculares Nacionais: Ética, $3^{\circ}$ e $4^{\circ}$ ciclos. Brasília, 1997(j)

Ministério da Educação. Secretaria de Educação Fundamental. Parâmetros Curriculares Nacionais: Trabalho e consumo, $3^{\circ}$ e $\mathbf{4}^{\circ}$ ciclos. Brasilia, 1997(1)

Ministério da Educação. Secretaria de Educação Fundamental. Parâmetros Curriculares Nacionais: Pluralidade cultural, $3^{\circ}$ e $4^{\circ}$ ciclos. Brasilia, 1997(m)

Ministério da Saúde. Fundação Oswaldo Cruz, IEC. Promoção da saúde: Carta de Ottawa, Declaração de Adelaide, Declaração de Sunsdvall e Declaração de Bogotá. Brasilia, 1996.

Nogueira O. O objeto das ciências humanas. In: Hirano S., $3^{a}$ ed, Pesquisa social: projeto e planejamento. São Paulo, TA. Queiroz, 1979.

OPAS. Oficina Sanitaria Panamericana, Oficina Regional de la Organización Mundial de la salud. Educación para la salud en el âmbito escolar: una 
Perspectiva integral y guia para la acción basada en la experiencia latinoamericana. Washington, 1995.

OPAS. Oficina Sanitaria Panamericana. Escuelas promotoras de salud: modelo y guía para la acción. Washington, sem data.

OPAS. Organización Mundial de la salud. Promocion y educacion de la salud escolar, una perspectiva integral: marco conceptual y operativo. Washington, 1995.

Sá CPS. A construção do objeto de pesquisa em representações sociais. Rio de Janeiro: EdUERJ, 1998.

São Paulo, Secretaria de Estado da Educação. Lideranças que fazem diferença, São Paulo, 1997

São Paulo, Secretaria de Estado da Educação. Professores que fazem diferença, São Paulo. 1997.

São Paulo, Secretaria de Estado da Educação. Pais que fazem diferença, São Paulo, 1997.

Silveira GT. O Ensino de saúde no Sistema Estadual de Ensino: do discurso legal à prática. São Paulo, 1994. [Dissertação de Mestrado- Faculdade de Saúde Pública da Universidade de São Paulo]

Simioni AMC et al. Metodologia qualitativa nas pesquisas em saúde coletiva: considerações teóricas e instrumentais. Série Monográfica, $n^{\circ} 2$, São Paulo, Faculdade de Saúde Pública da Universidade de São Paulo, 1996.

Simioni AMC, Lèfevre F, Pereira, IMTB. Metodologia qualitativa nas pesquisas em saúde coletiva: considerações teóricas e instrumentais. São Paulo, 1997. [Monografia apresentada à Faculdade de Saúde Pública da USP]

Spink MJ. O conceito de representação social na abordagem psicossocial. Cad.

Saúde Pública, Rio de Janeiro, 1993; 9(3): 300-308, jul/set.

Spink MJ, Gimenes MGG da. Práticas discursivas e produção de sentido: apontamentos metodológicos para a análise de discursos sobre saúde e doença. Rev Saúde e Sociedade, 1994; 3(2): 149-171.

Trivinos NSA. Introdução à pesquisa em ciências sociais: a pesquisa qualitativa em educação. São Paulo: Atlas; 1992. 
ANEXOS 


\section{ANEXO 1}

Localização da escola

- Mapa da região - 


\section{LOCALIZAÇÃO DA ESCOLA - MAPA DA REGIÃO}

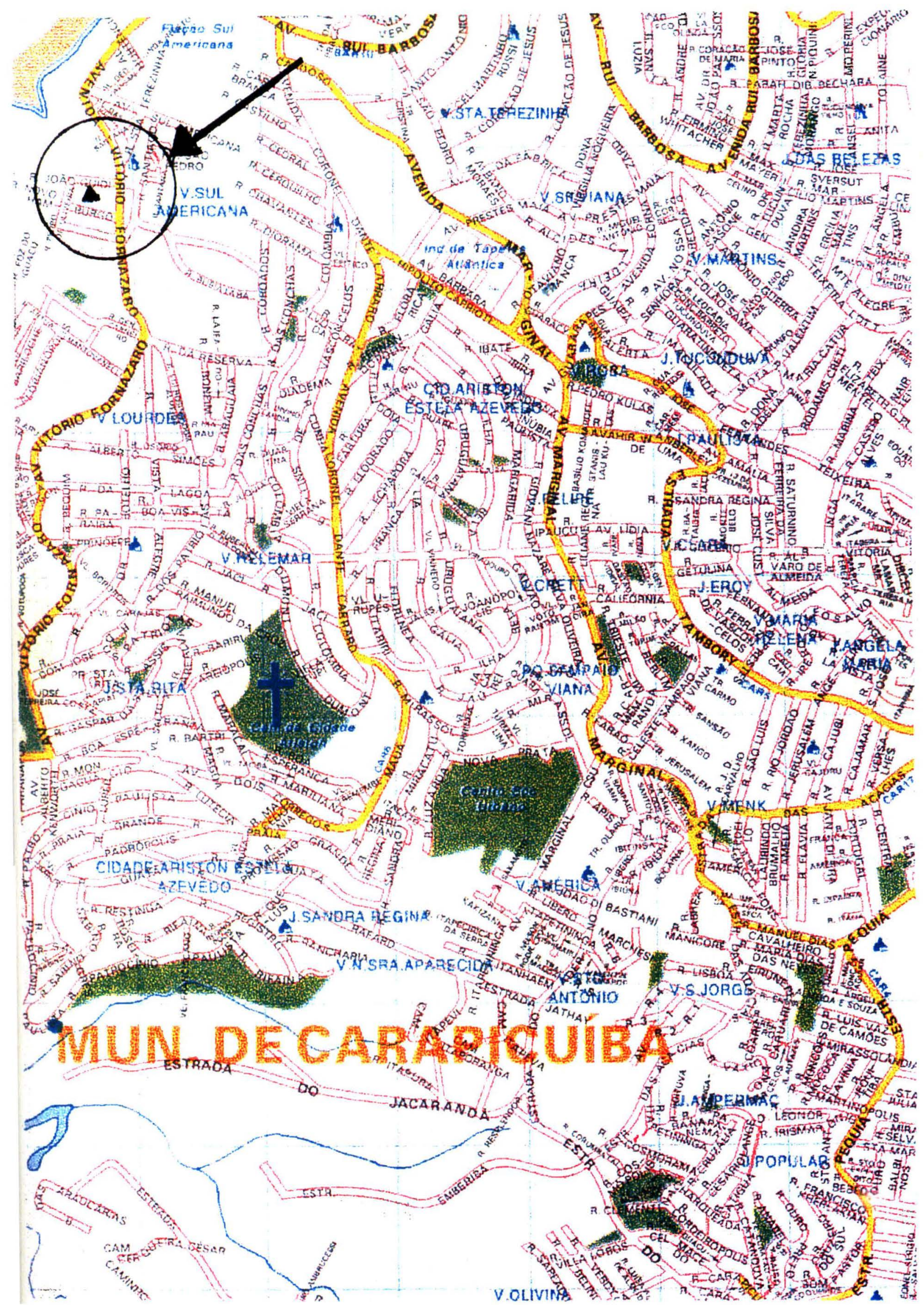


Anexo 2

Caracterização da escola 


\section{CARACTERIZAÇÃO DA ESCOLA}

Atendimento: $1^{a}$ a 8 a séries e Ensino Médio

Periodos de funcionamento : manhã. tarde e noite.

Número de salas : 16

Número de classes e alunos

\begin{tabular}{l|c|c}
\hline \multicolumn{3}{c}{ CLASSES E ALUNOS } \\
\hline Segmento de ensino & Classes & Alunos \\
\hline Ciclo I (1 a 4 séries) & 15 & 552 \\
\hline Ciclo II (5 a 8 séries) & 18 & 712 \\
\hline Ensino Médio & 15 & 668 \\
\hline Total & 48 & 1932 \\
\hline
\end{tabular}

Fonte: Cadastro da escola, Data base 10/03/2000

Situação de conservação do prédio: Ótima

Situação de conservação das dependências do prédio

\begin{tabular}{|l|l|l|l|l|}
\hline Dependências & \multicolumn{3}{|c|}{ Situação de conservação } \\
\cline { 2 - 5 } & Inadequada & Regular & Boa & Ótima \\
\hline Salas de aula & & & & \\
\hline Sala da diretora & & & & \\
\hline Sala das professoras & & & & \\
\hline $\begin{array}{l}\text { Sala de coordenaçào } \\
\text { pedagógica }\end{array}$ & & & & \\
\hline $\begin{array}{l}\text { Sala para trabalho } \\
\text { coletivo }\end{array}$ & & & & \\
\hline Sala para video & & & & \\
\hline Laboratório (s) & & & & \\
\hline Espaço para recreio & & & & \\
\hline Quadra & & & & \\
\hline Refeitório & & & & \\
\hline Cozinha & & & & \\
\hline Pátio coberto & & & & \\
\hline $\begin{array}{l}\text { Banheiros dos alunos e } \\
\text { das alunas }\end{array}$ & & & & \\
\hline $\begin{array}{l}\text { Banheiros dos professo- } \\
\text { res e das professoras }\end{array}$ & & & & \\
\hline Bebedouros & & & & \\
\hline
\end{tabular}


Dados do rendimento escolar nos últimos seis anos

\begin{tabular}{|c|c|c|c|}
\hline \multirow{2}{*}{$\begin{array}{c}\text { Taxa de } \\
\text { Movimentação } \\
\text { (ANO) }\end{array}$} & \multicolumn{3}{|c|}{ ENSINO FUNDAMENTAL } \\
\hline & $\begin{array}{c}\text { Promoção } \\
(\%)\end{array}$ & $\begin{array}{c}\text { Retenção } \\
(\%)\end{array}$ & $\begin{array}{c}\text { Evasão } \\
(\%)\end{array}$ \\
\hline 1994 & 83.6 & 14.7 & 1.7 \\
\hline 1995 & 86.3 & 11.3 & 2.5 \\
\hline 1996 & 89,1 & 8.8 & 2,0 \\
\hline 1997 & 87,4 & 10,3 & 2,3 \\
\hline 1998 & 96,3 & 2.6 & 1,1 \\
\hline \multirow[t]{2}{*}{1999} & 94,9 & 4.9 & 0,2 \\
\hline & \multicolumn{3}{|c|}{ ENSINO MEDDIO } \\
\hline $\begin{array}{c}\text { Taxa de } \\
\text { Movimentação } \\
(\text { ANO) } \\
\end{array}$ & $\begin{array}{c}\text { Promoçāo } \\
(\%)\end{array}$ & $\begin{array}{c}\text { Retenção } \\
(\%)\end{array}$ & $\begin{array}{c}\text { Evasão } \\
(\%)\end{array}$ \\
\hline 1994 & 88,1 & 5.7 & 6.2 \\
\hline 1995 & 77,0 & 7.0 & 16.0 \\
\hline 1996 & 85.5 & 3.2 & 11.3 \\
\hline 1997 & 85.1 & 3.2 & 11.7 \\
\hline 1998 & 83.7 & 4.5 & 11.8 \\
\hline 1999 & 89.0 & 8.0 & 3.0 \\
\hline
\end{tabular}

Fonte: Centro de Informaçóes Educacionais, SEE-São Paulo 
Anexo 3
Roteiro da Entrevista 


\section{ROTEIRO DE ENTREVISTA}

1. Você considera que a sua escola é uma boa escola? Sim? Não? Por quê?

2. Esta escola é saudável? Sim? Não? Por quê?

3. Qual o papel da escola na área da saúde?

4. O que é essencial para que a escola se torne saudável?

5. Quanto tempo leva para que a escola se transforme numa "escola saudável" e o que é necessário fazer para isto?

6. Qual a sua participação para que esta escola seja saudável?

7. Há diferenças entre a sua escola e as demais escolas da região? Qual(is)? 


$$
\begin{gathered}
\text { ANEXO } 4 \\
\text { Composição do quadro de } \\
\text { profissionais da escola }
\end{gathered}
$$




\section{COMPOSIÇÃO DO QUADRO DE PROFISSIONAIS DA ESCOLA}

Caracterização da Equipe de direção, segundo função exercida na escola, formação, tempo de exercício

\begin{tabular}{|c|c|c|c|c|c|c|c|c|c|}
\hline \multirow[b]{2}{*}{$\begin{array}{l}\text { Nível de } \\
\text { atuação }\end{array}$} & \multirow[b]{2}{*}{$\begin{array}{c}\text { Número } \\
\text { total }\end{array}$} & \multicolumn{2}{|c|}{ Formação } & \multicolumn{3}{|c|}{ Tempo de exercicio na escola } & \multicolumn{3}{|c|}{ Tempo de exercício no magistério } \\
\hline & & $\begin{array}{c}\text { Compativel } \\
\text { com a função }\end{array}$ & $\begin{array}{l}\text { Incompatível } \\
\text { com a função }\end{array}$ & \begin{tabular}{|ll}
$\begin{array}{l}\text { Até } \\
\text { anos }\end{array}$ & \\
\end{tabular} & $\begin{array}{l}\text { De } 6 \text { a } 10 \\
\text { anos }\end{array}$ & $\begin{array}{l}\text { Mais de } 10 \\
\text { anos }\end{array}$ & Até 5 anos & \begin{tabular}{|l|l|l|l} 
De 6 a 10 \\
anos
\end{tabular} & $\begin{array}{l}\text { Mais de } 10 \\
\text { anos }\end{array}$ \\
\hline Direção & 1 & 1 & 0 & 1 & 0 & 0 & 0 & 1 & 0 \\
\hline Vice-direção & 2 & 2 & 0 & 0 & 1 & 0 & 0 & 0 & 1 \\
\hline $\begin{array}{l}\text { Coordenação } \\
\text { pedagógica }\end{array}$ & 2 & 2 & 0 & 1 & 1 & 0 & 0 & 0 & 2 \\
\hline TOTAL & 5 & 5 & 0 & 2 & 2 & 0 & 0 & 1 & 3 \\
\hline
\end{tabular}

Fonte: Cadastro da escola, Data base: 20/3/2000

Corpo docente. agrupado segundo nível de atuação, sexo, formação, tempo de exercício na escola e no magistério.

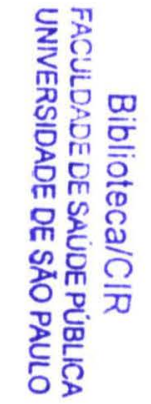

\begin{tabular}{|c|c|c|c|c|c|c|c|c|c|c|c|}
\hline \multirow[t]{2}{*}{$\begin{array}{l}\text { Nivel de } \\
\text { atuação }\end{array}$} & \multirow[t]{2}{*}{$\begin{array}{c}\text { Número } \\
\text { total }\end{array}$} & \multicolumn{2}{|c|}{ Formação } & \multirow[t]{2}{*}{ Homens } & \multirow[t]{2}{*}{ Mulheres } & \multicolumn{3}{|c|}{ Tempo de exercício na escola } & \multicolumn{3}{|c|}{\begin{tabular}{|l}
$\begin{array}{l}\text { Tempo de exercício no } \\
\text { magistério }\end{array}$ \\
\end{tabular}} \\
\hline & & $\begin{array}{l}\text { Compati- } \\
\text { vel com a } \\
\text { função }\end{array}$ & $\begin{array}{l}\text { Incompa- } \\
\text { tível com } \\
\text { a função }\end{array}$ & & & Até 5 anos & $\begin{array}{l}\text { De } 6 \text { a } \\
10 \text { anos }\end{array}$ & $\begin{array}{l}\text { Mais de } \\
10 \text { anos }\end{array}$ & $\begin{array}{l}\text { Até } 5 \\
\text { anos }\end{array}$ & \begin{tabular}{|l|} 
De 6 a \\
10 anos
\end{tabular} & $\begin{array}{l}\text { Mais de } \\
10 \text { anos }\end{array}$ \\
\hline $\begin{array}{l}\text { PEB-I (l a } 4 \\
\text { série) }\end{array}$ & 15 & 15 & 0 & 0 & 15 & 10 & 2 & 3 & 5 & 6 & 4 \\
\hline $\begin{array}{l}\text { PEB-II ( } 5 \text { a } 8 \\
\text { série e Ensino } \\
\text { Médio) }\end{array}$ & 36 & 36 & 0 & 14 & 22 & 24 & 8 & 4 & 10 & 21 & 5 \\
\hline TOTAL & 51 & 51 & 0 & 14 & 37 & 34 & 10 & 7 & 15 & 27 & 9 \\
\hline
\end{tabular}

Fonte: Cadastro da escola, Data base: $20 / 3 / 2000$ 


\section{ANEXO 5 \\ Categorias resultantes do reagrupamento das questões da entrevista}




\section{Categorias resultantes do reagrupamento das questões da entrevista}

\begin{tabular}{|l|l|}
\hline \multicolumn{1}{|c|}{ Questões da entrevista } & \multicolumn{1}{|c|}{ Categorias } \\
\hline $\begin{array}{l}\text { Questão 1 - Você considera que a sua escola é uma } \\
\text { boa escola? Sim? Não? Por quê? } \\
\text { Questão 7 - Quais as diferenças entre a sua escola e } \\
\text { as demais escolas da região? }\end{array}$ & $\begin{array}{l}\text { 1. Caracteristicas de uma boa } \\
\text { escola }\end{array}$ \\
\hline $\begin{array}{l}\text { Questão 2- Você considera que esta escola é } \\
\text { saudável? Sim? Não? Por quê? }\end{array}$ & $\begin{array}{l}\text { 2. Características de uma } \\
\text { escola saudável }\end{array}$ \\
\hline $\begin{array}{l}\text { Questão 3 - Qual o papel da escola na área da } \\
\text { saúde? }\end{array}$ & $\begin{array}{l}\text { 3. Papel da escola na área da } \\
\text { saúde }\end{array}$ \\
\hline $\begin{array}{l}\text { Questão 4 - O que é essencial para que a escola se } \\
\text { torne saudável? } \\
\text { Questão 5- Quanto tempo leva para que a escola se } \\
\text { transforme numa escola saudável? } \\
\text { Questão 6- O que é necessário fazer para que a } \\
\text { escola se transforme numa escola saudável? }\end{array}$ & $\begin{array}{l}\text { 4. Caracteristicas do processo } \\
\text { saudável }\end{array}$ \\
\hline
\end{tabular}




\section{ANEXO 6 \\ Categorias, temas}

e sub-temas referidos pelos

sujeitos nas entrevistas 


\begin{tabular}{|c|c|}
\hline \multicolumn{2}{|c|}{ Categorias, temas e sub-temas referidos pelos entrevistados } \\
\hline Categoria & Temas/ sub-temas \\
\hline \multirow{8}{*}{$\begin{array}{l}\text { 1. Caracteristicas de uma boa } \\
\text { escola }\end{array}$} & 1.1. Estrutura e ambiente fisico de boa qualidade \\
\hline & $\begin{array}{l}\text { 12. Gestão escolar } \\
\text { 12.1. Escola historicamente comprometida com a melhoria da qualidade } \\
\text { 1.2. Projeto escolar claramente definido e conhecido pela comunidade } \\
\text { 1.2.3. Adesão da comunidade ao projeto da escola (participa de sua implementação) } \\
\text { 1 2.4. Funcionamento efetivo das instâncias de democratização da escola (Conselho de Escola. } \\
\text { Conselho de Classe. Associação de Pais e Mestres e Grêmio Estudantil) } \\
\text { 1.2.5. Presença fisica da direção na escola e reconhecida competência administrativa } \\
\text { 1.2.6. Compromisso da direção com a solução dos problemas da escola } \\
\text { 1.2.7. Direção contribui para elevar auto-estima dos professores } \\
\text { 1.2.8. Interesse e compromisso da equipe em realizar um bom trabalho } \\
\text { 1.2. Bom entrosamento entre os elementos da equipe } \\
\text { 1.2.10. Seriedade e profissionalismo da equipe escolar }\end{array}$ \\
\hline & 1.3. Boa qualidade de ensino \\
\hline & 1.3.1. Bons resultados de rendimento e desempenho escolar \\
\hline & $\begin{array}{l}\text { 1.3.2. Foco do trabalho pedagógico é a permanência do aluno na escola e sua efetiva aprendizagem } \\
\text { 1.3.3. Otimizacão do tempo pedagógico }\end{array}$ \\
\hline & $\begin{array}{l}\text { 1.3.4. Diversificação das atividades de ensino e aprendizagem e utilização de recursos didático- } \\
\text { pedagogicos }\end{array}$ \\
\hline & $\begin{array}{l}\text { 1.3.5. Formaça continuada dos professoras nas horas de trabalho pedagógico, como estratégia para } \\
\text { melhorar a qualidade das aulas. }\end{array}$ \\
\hline & $\begin{array}{l}\text { 13.6. Familia dos professores e funcionários confia na qualidade do trabalho da escola (fithos, } \\
\text { sobrinhos e netos estudam na escola) }\end{array}$ \\
\hline \multirow{9}{*}{$\begin{array}{l}\text { 2. Caracteristicas de uma } \\
\text { escola saudável }\end{array}$} & 2.1. Ambiente fisico de boa qualidade \\
\hline & 2.2. Ambientes e/ou espaços da escola particularmente saudáveis \\
\hline & 2.2.1. pátio escolar \\
\hline & 2.2.2. refeitório \\
\hline & 2.2.3. biblioteca \\
\hline & 2.2.4. sala de vídeo \\
\hline & 2.2.5. salas de aula \\
\hline & 2.2.6. sala do professor \\
\hline & 12.2.7. hanheiros \\
\hline
\end{tabular}




\begin{tabular}{|c|c|}
\hline \multicolumn{2}{|c|}{ Categorias, temas e sub-temas referidos pelos entrevistados } \\
\hline Categoria & Temas/ sub-temas \\
\hline \multirow[t]{4}{*}{$\begin{array}{l}\text { 2. Características de uma } \\
\text { escola saudável }\end{array}$} & $\begin{array}{l}\text { 2.3. Gestão escolar } \\
\text { 2.3.1. Clima amigável e bom nivel de organização } \\
\text { 2.3.2. Projeto escolar claramente definido e conhecido pela comunidade escolar que inclui a } \\
\text { preocupação com valores } \\
\text { 2.3.3. Adesão da comunidade ao projeto da escola porque a escola é boa e saudável } \\
\text { (participa na sua implementação) } \\
\text { 2.3.4. Iuncionamento efetivo das instâncias de democratização da escola (Conselho de Escola e de } \\
\text { Classe. Associação de Pais e Mestres e Grêmio Estudantil) } \\
\text { 2.3.5. Compromisso da direção com a solução dos problemas da escola } \\
\text { 2.3.6. Seriedade e profissionalismo dos professores } \\
\text { 2.3.7. Responsabilização dos alunos e comunidade pela conservação da escola } \\
\text { 2.3.8. Preocupação com a qualidade de vida das pessoas que vivem na escola }\end{array}$ \\
\hline & $\begin{array}{l}\text { 2.4. Ensino de boa qualidade } \\
\text { 2.4. 1. Foco do trabalho pedagógico é a permanência do aluno na escola e sua aprendizagem efetiva } \\
\text { 2.4.2. Bons resultados de rendimento e desempenho escolar } \\
\text { 2.4.3. Bom nivel de participação dos alunos }\end{array}$ \\
\hline & 2.5. Alunos saudáveis e com bons hábitos de convivência escolar e de higiene \\
\hline & $\begin{array}{l}\text { 2.6. Relações de reciprocidade entre uma boa escola e uma escola saudável } \\
\text { 2.6.1. Nem sempre uma boa escola é uma escola saudável } \\
\text { 2.6.2. Toda escola saudável é uma boa escola }\end{array}$ \\
\hline $\begin{array}{l}\text { 3. Papel da escola na área da } \\
\text { sinde }\end{array}$ & $\begin{array}{l}\text { 3.1. promoção da saude pela articulação da teoria com a prática } \\
\text { 3.2. Iramsmissão de conhecimentos e de referências no campo da saúde } \\
\text { 3.3. orientação de pais } \\
\text { 3.4. orientação de alunos } \\
\text { 3.5. formação de valores } \\
\text { 3.6. atendimento as expectativas dos alunos } \\
\text { 3.7. encaminhamento dos alunos aos serviços de saude } \\
\text { 3.8. trabalho pedagógico que assegure permanéncia do aluno na escola e sua aprendizagem efetiva } \\
\text { 3.9. prevenção }\end{array}$ \\
\hline $\begin{array}{l}\text { 4. Características do processo } \\
\text { de construção de uma escola } \\
\text { saudável }\end{array}$ & $\begin{array}{l}\text { 4.1. Tempo de construção de uma escola saudável } \\
\text { 4.1.1. Tempo é previsivel, em tomo de dois anos } \\
\text { 4.1.2. Não há como definir, pois o processo é continuo }\end{array}$ \\
\hline
\end{tabular}




\begin{tabular}{|c|c|}
\hline \multicolumn{2}{|c|}{ Categorias, temas e sub-temas referidos pelos entrevistados } \\
\hline Categoria & Temas/sub-temas \\
\hline $\begin{array}{l}\text { 4. Caracteristicas do processo } \\
\text { de construção de uma escola } \\
\text { saudável }\end{array}$ & 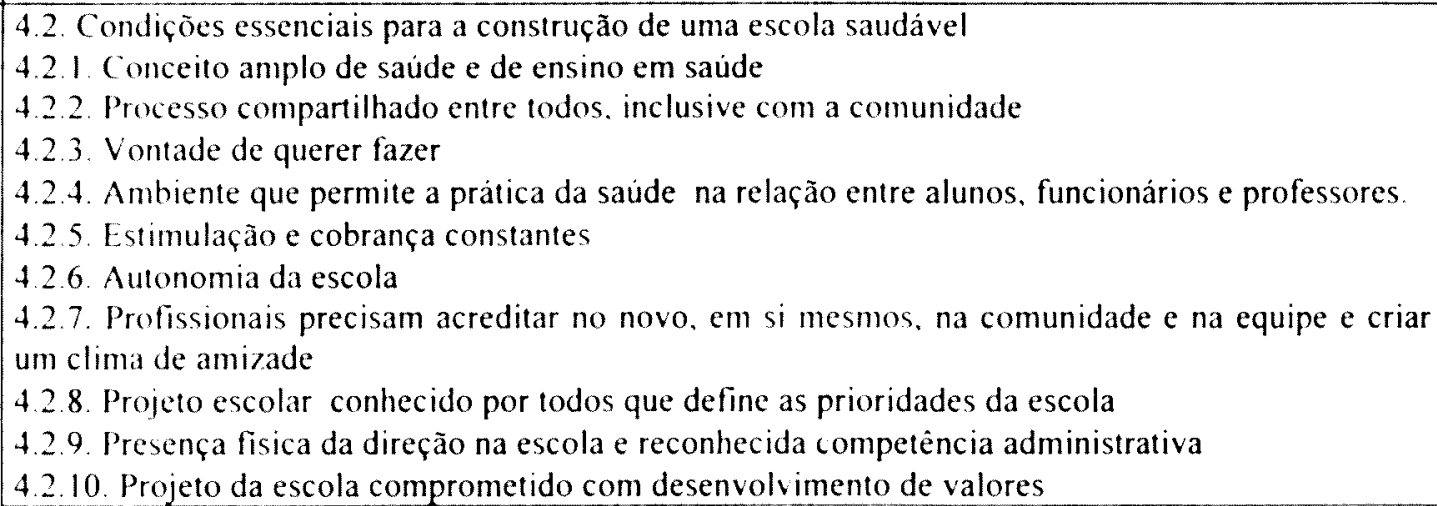 \\
\hline & $\begin{array}{l}\text { 4.3. Contribuição pessoal para que a escola seja saudável } \\
\text { 4.3.1. Assegurar condições básicas para o bom funcionamento da escola (condições fisicas e } \\
\text { materiais) } \\
\text { 43.2. Estimular a escola } \\
\text { 4.3.3. Acompanhar e cobrar da escola o processo de se tornar uma escola saudável } \\
\text { 4.3.4. Incentivar a escola para que trabalhe articuladamente com a comunidade } \\
\text { 4.3.5. Estabelecer canais de comunicação entre os professores e a familia dos alunos, para assegurar } \\
\text { a escolaridade básica ao aluno } \\
\text { 4.3.6. Aperfeiçoar relações entre professores e coordenação pedagógica } \\
\text { (estabelecimento de clima de honestidade e franqueza) } \\
\text { 4.3.7. Disponibilidade para o diálogo } \\
\text { 4.3.8. Ampliar oportunidades de participação dos alunos em jogos e competições } \\
\text { 4.3.9. Compromisso com a aprendizagem do aluno em sala de aula }\end{array}$ \\
\hline & 4.4. Receio quanto à descontinuidade do projeto da escola \\
\hline
\end{tabular}




\section{Anexo 7}

Temas, sub-temas e expressões-chave

Discursos de 1 a 12 


\section{DISCURSO 1-CATEGORIAS, TEMAS, SUB-TEMAS E EXPRESSOES CHAVE}

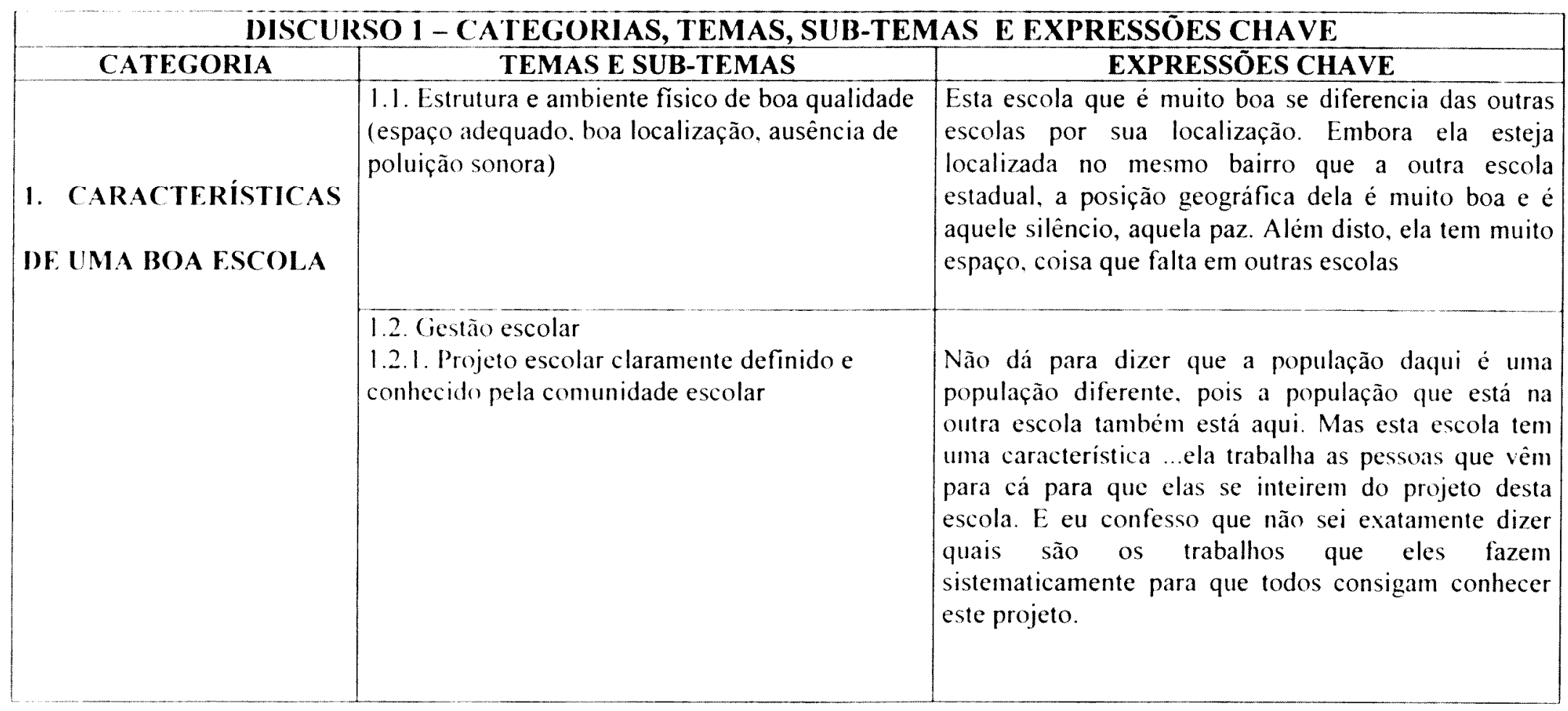




\begin{tabular}{|c|c|c|}
\hline \multicolumn{3}{|c|}{ DISCURSO 1 - CATEGORIAS, TEMAS, SUB-TEMAS E EXPRESSÕES CHAVE } \\
\hline CATEGORIA & TEMAS E SUB-TEMAS & EXPRESSÕES CHAVE \\
\hline $\begin{array}{l}\text { 1. CARACTERISTICAS } \\
\text { DE UMA BOA ESCOLA }\end{array}$ & $\begin{array}{l}\text { 1.2.2. Adesão da comunidade escolar ao projeto } \\
\text { da escola (participa na sua implementação) }\end{array}$ & $\begin{array}{l}\text { Também não sei como eles fazem para que a } \\
\text { comunidade compre o projeto da escola e participe da } \\
\text { sua implementação. Eu vou citar uma coisa que } \\
\text { observei muito quando venho aqui, mesmo correndo o } \\
\text { risco de ser mal interpretado - a escola nasceu } \\
\text { tipicamente de descendentes de italianos e recebeu, a } \\
\text { partir de um periodo. a comunidade nordestina, que é } \\
\text { a grande maioria em Carapicuiba. Pois o pessoal que } \\
\text { chegou assumiu os valores dos que já estavam aqui e } \\
\text { compraram o projeto da escola. Dizendo de outro } \\
\text { jeito, esta escola está bastante inteirada com a } \\
\text { comunidade, o que é muito produtivo. }\end{array}$ \\
\hline \multirow[t]{2}{*}{$\begin{array}{l}\text { 2. CARACTERÍSTICAS } \\
\text { DE UMA ESCOLA } \\
\text { SAUDÁVEL }\end{array}$} & $\begin{array}{l}\text { 2.1. Ambiente físico de boa qualidade } \\
\text { (arborização) }\end{array}$ & $\begin{array}{l}\text { Você observou que tem muito verde. muita flor ...tem } \\
\text { muita vida nessa escola?! Aqui você vê a presença da } \\
\text { vida. você sente a natureza rodeando a escola. Você } \\
\text { observou como as passarelas por onde os alunos } \\
\text { caminham são floridas?! }\end{array}$ \\
\hline & $\begin{array}{l}\text { 2.2. Ambientes e/ou espaços da escola } \\
\text { particularmente saudáveis } \\
\text { 2.2.1. pátio escolar } \\
\text { 2.2.2. refeitório }\end{array}$ & $\begin{array}{l}\text { Um outro lugar que eu gosto muito aqui da escola é o } \\
\text { pátio, porque está sempre com alunos e é um pátio } \\
\text { alegre... } \\
\text { Outro lugar que me chama bastante atenção é o } \\
\text { refeitório, onde as pessoas se reúnem para as } \\
\text { refeições, sentadas, comemnum lugar limpo. }\end{array}$ \\
\hline
\end{tabular}




\begin{tabular}{|c|c|c|}
\hline \multicolumn{3}{|c|}{ DISCURSO 1 - CATEGORIAS, TEMAS, SUB-TEMAS E EXPRESSÖES CHAVE } \\
\hline CATEGORIA & TEMAS E SUB-TEMAS & EXPRESSÕES CHAVE \\
\hline \multirow[t]{3}{*}{$\begin{array}{l}\text { 2. CARACTERISTICAS } \\
\text { DF IMA FSCOLA } \\
\text { SIUDAVI }\end{array}$} & $\begin{array}{l}\text { 2.3. Gestão escolar } \\
\text { 2.3.1. Boa organização geral }\end{array}$ & $\begin{array}{l}\text { Quando a gente entra na escola pela primeira vez, a } \\
\text { gente sente que alguma coisa diferente acontece } \\
\text {...depois que a gente cruza o muro da escola. } \\
\text { conforme você vai passando pela escola, vai } \\
\text { percebendo que não é um clemento so., mas sãovários } \\
\text { elementos que vão se juntando...e fica dificil dizer o } \\
\text { que está fazendo a escola ser mais saudável. A } \\
\text { organização geral desta escola chama a atenção de } \\
\text { qualquer um. }\end{array}$ \\
\hline & $\begin{array}{l}\text { 2.4. Ensino de boa qualidade } \\
\text { 2.4.1. Foco do trabalho pedagógico é a } \\
\text { permanência do aluno na escola e sua } \\
\text { aprendizagem efetiva }\end{array}$ & $\begin{array}{l}\text { A escola tem um compromisso com o aluno ...ela faz } \\
\text { o que pode para que o aluno permaneça na escola ... } \\
\text { eles estão mais interessados em que os alunos } \\
\text { aprendam do que em colocar os alunos para fora. } \\
\text { como em tantas escolas. }\end{array}$ \\
\hline & $\begin{array}{l}\text { 2.4.2. Bons resultados de rendimento e } \\
\text { desempenho escolar }\end{array}$ & $\begin{array}{l}\text { A escola oferece o suporte necessário para que o aluno } \\
\text { possa se expressar, se exercitar, para que ele possa ser } \\
\text { ele lá fora. em todos os campos... faz os alunos se } \\
\text { sentirem felizes. a gente nota que existe um respeito } \\
\text { um pelo outro. Os resultados tem sido bons e então eu } \\
\text { acho que isso é o maior sintoma de que a escola é } \\
\text { saudáel... }\end{array}$ \\
\hline
\end{tabular}




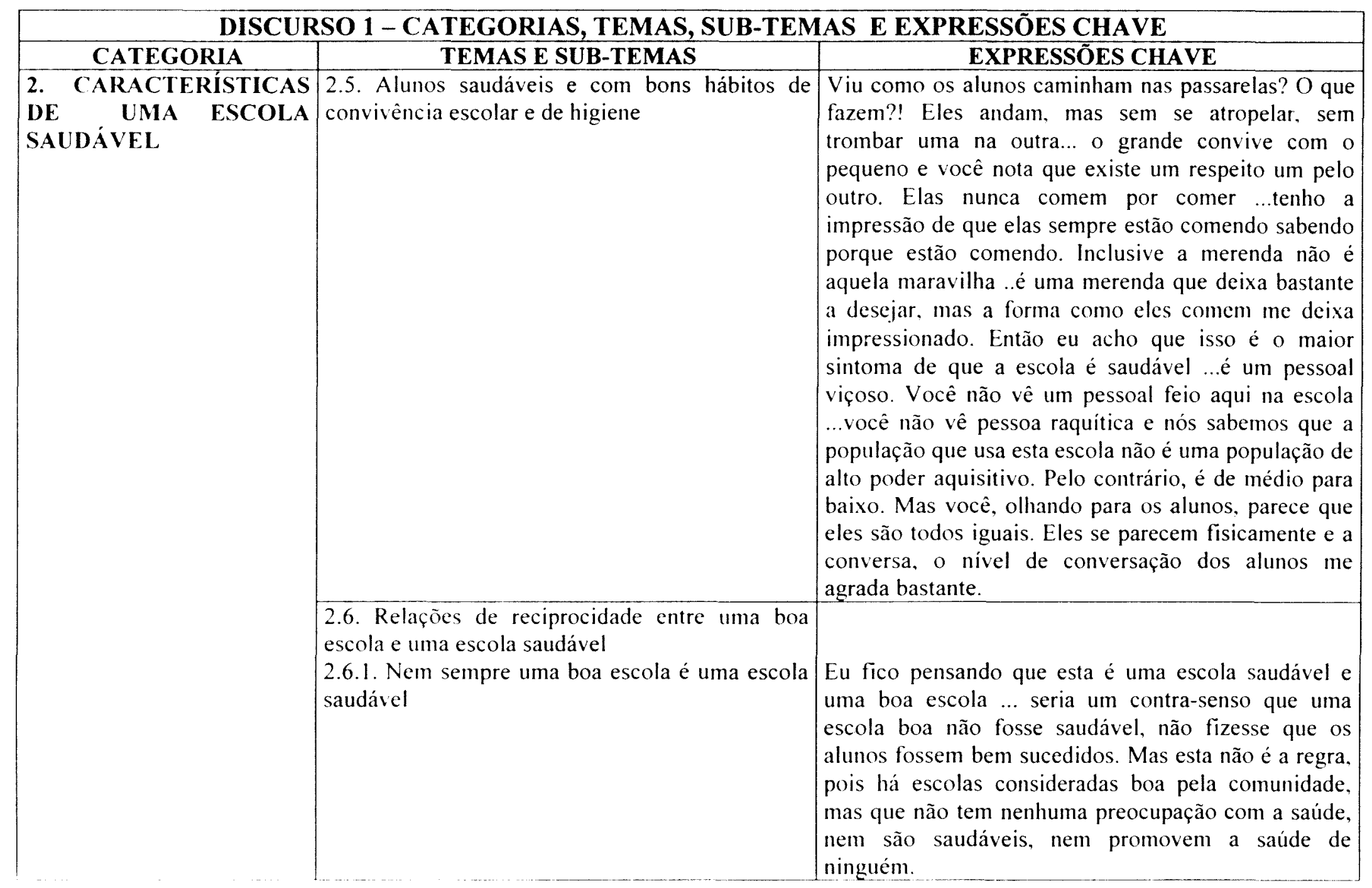




\begin{tabular}{|c|c|c|}
\hline \multicolumn{3}{|c|}{ DISCURSO 1 - CATEGORIAS, TEMAS, SUB-TEMAS E EXPRESSŌES CHAVE } \\
\hline CATEGORIA & TEMAS E SUB-TEMAS & EXPRESSÕES CHAVE \\
\hline \multirow[t]{2}{*}{$\begin{array}{l}\text { 3. PAPEL DA ESCOLA } \\
\text { NA ÁREA DA SAÚDE }\end{array}$} & $\begin{array}{l}\text { 3.1. promoção da saúde pela articulação da teoria } \\
\text { com a prática }\end{array}$ & $\begin{array}{l}\text { Esta escola promove a saúde ... vejo que ela está } \\
\text { sempre garantindo que as pessoas possam exercitar } \\
\text { esses conhecimentos dentro de suas diferentes esferas } \\
\text { de trabalho, desde lá da primeira série até o aluno do } \\
\text { último ano do Ensino Médio. É lógico que ela não } \\
\text { pode trabalhar uma coisa sem a outra, pois o conteúdo } \\
\text { e a prática se complementam ... só que não se pode dar } \\
\text { mais valor a uma coisa que a outra. Aliás, a prática } \\
\text { pode ser elaborada a partir de um conhecimento e } \\
\text { vice-versa e a escola está atenta a estas duas } \\
\text { dimensões. Tudo é importante ...não pode deixar um e } \\
\text { trabalhar o outro.. }\end{array}$ \\
\hline & $\begin{array}{l}3.2 \text { transmissão de conhecimentos e de } \\
\text { referências no campo da saúde física e espiritual }\end{array}$ & $\begin{array}{l}\text { A escola passa através de seus professores, de seu } \\
\text { corpo administrativo, todas as noções do que seria } \\
\text { uma pessoa saudável, o que uma pessoa saudável } \\
\text { precisa ter. Ela não fala só da saúde do corpo, ela } \\
\text { trabalha também a saúde do espírito e faz as duas } \\
\text { coisas juntas. Estando sempre atualizada com o que } \\
\text { está acontecendo de novo lá fora, ela está sempre } \\
\text { procurando passar esses conhecimentos. }\end{array}$ \\
\hline $\begin{array}{l}\text { 4. CARACTERISTICAS } \\
\text { DO PROCESSO DE } \\
\text { CONSTRUCÃO DE UMA } \\
\text { ESCOLA SAUDÁVEL }\end{array}$ & $\begin{array}{l}\text { 4.1. Tempo de construção de uma escola } \\
\text { saudável } \\
\text { 4.1.1. Tempo é previsivel, em torno de dois anos }\end{array}$ & $\begin{array}{l}\text { Eu acho que a escola precisa pelo menos ter uma } \\
\text { caminhada: uma caminhada de uns dois anos ...o } \\
\text { grupo todo juntos...um pouquinho mais. }\end{array}$ \\
\hline
\end{tabular}




\begin{tabular}{|c|c|c|}
\hline \multicolumn{3}{|c|}{ DISCURSO 1 - CATEGORIAS, TEMAS, SUB-TEMAS E EXPRESSÕES CHAVE } \\
\hline CATEGORIA & TEMAS E SUB-TEMAS & EXPRESSÕES CHAVE \\
\hline \multirow[t]{3}{*}{$\begin{array}{l}\text { 4. CARACTERISTICAS } \\
\text { DO PROCESSO DE } \\
\text { CONSTRUCÃO DE UMA } \\
\text { ESCOLA SAUDÁVEL }\end{array}$} & $\begin{array}{l}\text { 4.2. Condições essenciais para a construção de } \\
\text { uma escola saudável } \\
4.2 .1 \text {. Conceito amplo de saúde e de ensino em } \\
\text { saude }\end{array}$ & $\begin{array}{l}\text { A escola deve saber bem o que é saúde e como ensinar } \\
\text { saúde ..se ela achar que é só ausência de doença, ela } \\
\text { só vai trabalhar aquele pout-pourri de doenças, muito } \\
\text { chato e só para a prova, não para a vida }\end{array}$ \\
\hline & $\begin{array}{l}\text { 4.2.2. Ambiente que permite a prática da saúde } \\
\text { na relação entre alunos, funcionários e } \\
\text { professores. }\end{array}$ & $\begin{array}{l}\text { A escola deve saber passar o conceito de saúde, não } \\
\text { de uma forma falada, mas que os alunos, professores e } \\
\text { funcionários pratiquem essa saúde no exercício da } \\
\text { convivência com o outro. E que as pessoas que aqui } \\
\text { dentre estejam, entendam e usem essa saúde em } \\
\text { beneficio próprio }\end{array}$ \\
\hline & $\begin{array}{l}\text { 4.4. Contribuição pessoal para que a escola seja } \\
\text { saudáel } \\
\text { 4.4.1. assegurar condições básicas para o bom } \\
\text { funcionamento da escola (condições físicas e } \\
\text { materiais) }\end{array}$ & $\begin{array}{l}\text { Eu acho que a função do dirigente da Diretoria o } \\
\text { envolvimento é o menor possivel. Tenho que ter } \\
\text { consciência de quais são as condições de que a escola } \\
\text { necessita para se tornar saudável e assegurar estas } \\
\text { condições ... assegurar as condições fisicas e os } \\
\text { materiais ... funcionar como um elo entre a escola e o } \\
\text { sistema, a Secretaria... } \\
\text { o meu papel é o de estimular a escola para que use } \\
\text { bem suas condições fisicas e os materiais de que } \\
\text { dispõe para que ela faça um trabalho e seja boa e } \\
\text { saudável } \\
\text { Tenho que lembrar a escola das condições que ela tem } \\
\text { e do que é obrigada a oferecer à comunidade. Então. } \\
\text { cobrar da escola o dever que ela tem de ser uma escola } \\
\text { boa c saudável. dadas todas as condições que ela tem c } \\
\text { que são favoráveis a esse projeto. }\end{array}$ \\
\hline
\end{tabular}




\begin{tabular}{|c|c|c|}
\hline \multicolumn{3}{|c|}{ DISCURSO 2-CATEGORIAS, TEMAS, SUB-TEMAS E EXPRESSÕES CHAVE } \\
\hline CATEGORIA & TEMAS E SUB-TEMAS & EXPRESSÕES CHAVE \\
\hline \multirow{3}{*}{$\begin{array}{l}\text { 1. CARACTERISTICAS } \\
\text { DE UMA BOA ESCOLA }\end{array}$} & $\begin{array}{l}\text { 1.1. Estrutura e ambiente fisico de boa qualidade } \\
\text { (escola limpa e esteticamente bonita) }\end{array}$ & $\begin{array}{l}\text { Esta escola é uma boa escola primeiro porque é uma } \\
\text { escola limpa, é uma escola bonita ... }\end{array}$ \\
\hline & 1.2. Gestão escolar & \\
\hline & $\begin{array}{l}\text { 1.2.2. Compromisso da diretora com a solução } \\
\text { dos problemas da escola }\end{array}$ & $\begin{array}{l}\text { Todas as escolas de Carapicuiba possuem boas } \\
\text { condições fisicas, até mesmo as mais humildes. O eu } \\
\text { faz diferença nesta escola é que ela já tem este } \\
\text { traballho há algum tempo, enquanto que outras estão } \\
\text { começando este trabalho. Em Carapicuiba nós temos } \\
\text { várias escolas que estão caminhando nesta direção. } \\
\text { Nós temos várias escolas boas. bonitas, saudáveis. } \\
\text { Esta está na frente, porque este trabalho já vem sendo } \\
\text { feito há mais tempo. Então a diferença é exatamente } \\
\text { essa: esta já está num estágio mais avançado - é muito } \\
\text { organizada, faz um bom trabalho pedagógico e uma } \\
\text { administração excelente. } \\
\text { A gente vê que esta é uma boa escola pela constante } \\
\text { preocupação da diretora em atacar os vários } \\
\text { problemas que a escola vai apresentando }\end{array}$ \\
\hline
\end{tabular}




\begin{tabular}{|c|c|c|}
\hline \multicolumn{3}{|c|}{ DISCURSO 2 - CATEGORIAS, TEMAS, SUB-TEMAS E EXPRESSÕES CHAVE } \\
\hline CATEGORIA & TEMAS E SUB-TEMAS & EXPRESSÕES CHAVE \\
\hline \multirow[t]{3}{*}{$\begin{array}{l}\text { 1. CARACTERISTICAS } \\
\text { DE UMA BOA ESCOLA }\end{array}$} & $\begin{array}{l}\text { 1.2.3. Escola historicamente comprometida com } \\
\text { a melhoria da qualidade }\end{array}$ & $\begin{array}{l}\text { O que faz diferença nesta escola é que ela já teın este } \\
\text { trabalho há algum tempo, enquanto que outras estão } \\
\text { começando este trabalho. Em Carapicuiba nós temos } \\
\text { várias escolas que estão caminhando nesta direção. } \\
\text { Nós temos várias escolas boas, bonitas, saudáveis. } \\
\text { Esta está na frente, porque este trabalho já vem sendo } \\
\text { feito há mais tempo. Há mais tempo que esta escola } \\
\text { vem procurando sempre melhorar de qualidade. Então } \\
\text { a diferença é exatamente essa: esta já está num estágio } \\
\text { mais avançado - é muito organizada, faz um bom } \\
\text { trabalho pedagógico e uma administração excelente. }\end{array}$ \\
\hline & $\begin{array}{l}\text { 1.3. Fnsino de boa qualidade } \\
\text { 1.3.1. Foco do trabalho pedagógico é a } \\
\text { permanência do aluno na escola e sua } \\
\text { aprendizagem efetiva }\end{array}$ & $\begin{array}{l}\text { Esta escola é uma boa escola e a gente vê pela } \\
\text { preocupação dos professores em fazer com que os } \\
\text { alunos possam aprender e tenham bons resultados na } \\
\text { escola...eles fazem muito esforço para que o aluno } \\
\text { permaneça na escola e isto faz muita diferença para os } \\
\text { alunos e para a escola. }\end{array}$ \\
\hline & $\begin{array}{l}\text { 1.3.2. Bons resultados de rendimento e } \\
\text { desempenho escolar }\end{array}$ & $\begin{array}{l}\text { A escola é boa porque tem obtido bons resultados e } \\
\text { mesmo que estes não sejam excelentes, eles vêm } \\
\text { sempre melhorando. Muitos alunos daqui têm se saido } \\
\text { bem aqui e fora daqui, porque são bem preparados. } \\
\text { aprenderam a argumentar, a consultar jomais, por } \\
\text { exemplo. }\end{array}$ \\
\hline
\end{tabular}




\begin{tabular}{|c|c|c|}
\hline \multicolumn{3}{|c|}{ DISCURSO 2 - CATEGORIAS, TEMAS, SUB-TEMAS E EXPRESSÕES CHAVE } \\
\hline CATEGORIA & TEMAS E SUB-TEMAS & EXPRESSÕES CHAVE \\
\hline \multirow[t]{2}{*}{$\begin{array}{l}\text { 2. CARACTERISTICAS } \\
\text { DE UMA ESCOLA } \\
\text { SAUDÁVEL }\end{array}$} & $\begin{array}{l}\text { 2.1. Ambiente fisico de boa qualidade } \\
\text { (limpeza, ausência de pichação) }\end{array}$ & $\begin{array}{l}\text { A escola deve saber bem o que é saúde e como cnsinar } \\
\text { saúde ..se ela achar que é só ausência de doença, ela } \\
\text { só vai trabalhar aquele pout-pourri de doenças, muito } \\
\text { chato e só para a prova, não para a vida }\end{array}$ \\
\hline & $\begin{array}{l}\text { 2.3. Gestão escolar } \\
\text { 2.3.1. Clima amigável e bom nivel de } \\
\text { organização } \\
\text { 2.3.2. Projeto escolar claramente definido e } \\
\text { conhecido pela comunidade escolar que inclui a } \\
\text { preocupação com valores }\end{array}$ & $\begin{array}{l}\text { Esta escola é uma boa escola primeiro porque é uma } \\
\text { escola organizada ...todos aqui contribuem para que } \\
\text { ela seja uma escola com um clima bom, favorável ao } \\
\text { trabalho, que faça com que todos se sintam bem aqui } \\
\text { dentro ...Tudo está no seu lugar., não há nenhuma } \\
\text { bagunça e se sabe logo, desde que o cara entra na } \\
\text { escola, que se chegou a um lugar diferente. E é lógico } \\
\text { que este clima de saúde ajuda a tudo dar certo aqui. } \\
\hat{E} \text { uma escola saudável que tem um projeto } \\
\text { pedagógico concreto...este projeto está muito } \\
\text { preocupado com valores .... valores morais, valores de } \\
\text { aprendizagem... os valores de conteúdo estes estão } \\
\text { presentes. Então eu vejo como uma escola saudável. } \\
\text { Também os valores tipo solidariedade. relações } \\
\text { humanas, tudo isto está presente. }\end{array}$ \\
\hline
\end{tabular}




\begin{tabular}{|c|c|c|}
\hline \multicolumn{3}{|c|}{ DISCURSO 2 - CATEGORIAS, TEMAS, SUB-TEMAS E EXPRESSÕES CHAVE } \\
\hline CATEGORIA & TEMAS E SUB-TEMAS & EXPRESSŌES CHAVE \\
\hline \multirow[t]{3}{*}{$\begin{array}{l}\text { 2. CARACTERISTICAS } \\
\text { DE IMA ESCOLA } \\
\text { SAUDÁVEL }\end{array}$} & $\begin{array}{l}\text { 2.3.3. Adesão da comunidade ao projeto da } \\
\text { escola porque a escola é boa e saudável } \\
\text { (participa na sua implementação) }\end{array}$ & $\begin{array}{l}\text { A comunidade aprova o que a escola faz e também } \\
\text { ajuda a que tudo ande bem. A comunidade tem } \\
\text { consciência de que esta é uma boa escola e uma escola } \\
\text { saudável... existe até uma pressão da comunidade para } \\
\text { colocar um filho. uma filha aqui. Ás vezes, até os pais } \\
\text { de outros bairros querem colocar seus filhos aqui. } \\
\text { porque sabem disso. A comunidade está dentro da } \\
\text { escola...a escola é dela, ela é a comunidade ...e não há } \\
\text { uma escola que seja boa ou saudável sem que isto } \\
\text { aconteça } \\
\text { A gente percebe que boa parte do que a escola } \\
\text { conseguiu. conseguiu porque a direção está sempre } \\
\text { muito preocupada em resolver todos os problemas da } \\
\text { escola ...porque a gente está falando que esta é uma } \\
\text { boa escola e uma escola saudável, mas aqui também } \\
\text { há problemas, como em todas as outras. }\end{array}$ \\
\hline & $\begin{array}{l}\text { 2.3.5. Seriedade e profissionalismo dos } \\
\text { professores }\end{array}$ & $\begin{array}{l}\text { Os professores também têm consciência de que esta } \\
\text { escola é diferente ...ela é saudável mesmo e eles } \\
\text { gostam de trabalhar aqui. São muito sérios ...é lógico } \\
\text { que há exceções, mas acho que eles procuram ser bom } \\
\text { profissionais }\end{array}$ \\
\hline & $\begin{array}{l}\text { 2.4. Ensino de boa qualidade } \\
\text { 2.4.1. Foco do trabalho pedagógico é a } \\
\text { permancincia do aluno na escola e sua } \\
\text { aprendizagem efetiva }\end{array}$ & $\begin{array}{l}\text { A direção, a coordenação e os professores trabalham } \\
\text { para o aluno... para que cle possa se dar bem aqui. } \\
\text { Com ja disse. elas não deixam o aluno desistir ..nunca. } \\
\text { Elas batalham para que ele vá bem, seja um bom } \\
\text { aluno, consiga ser aprovado. }\end{array}$ \\
\hline
\end{tabular}




\begin{tabular}{|c|c|c|}
\hline \multicolumn{3}{|c|}{ DISCURSO 2 - CATEGORIAS, TEMAS, SUB-TEMAS E EXPRESSÕES CHAVE } \\
\hline CATEGORIA & TEMAS E SUB-TEMAS & EXPRESSÕES CHAVE \\
\hline \multirow[t]{3}{*}{$\begin{array}{l}\text { 2. CARACTERÍSTICAS } \\
\text { DE UMA ESCOLA } \\
\text { SAUDÁVEL }\end{array}$} & $\begin{array}{l}\text { 2.4.2. Alunos saudáveis e com bons hábitos de } \\
\text { convivência escolar e de higiene } \\
\text { (alunos usam uniforme, são bem comportados e } \\
\text { limpos) }\end{array}$ & $\begin{array}{l}\text { Os alunos procuram estar uniformizados, procuram se } \\
\text { vestir bem. Procuram se pentear. Procuram estar bem } \\
\text { - vamos dizer - tomar banho. Os alunos procuram } \\
\text { andar de maneira comportada. mais bonita. } \\
\text { Dificilmente se vê aluno correndo, suado e a gente } \\
\text { percebe isto. Talvez até tragam isto de casa ou seja } \\
\text { coisa da escola que tem mais de } 20 \text { anos ... mas a } \\
\text { gente percebe que os alunos têm um bom } \\
\text { comportamento. Tudo isso são valores que estão } \\
\text { estampados. Eles aparecem. Os alunos zelam por seu } \\
\text { material ... são valores. Se fala em voz num tom de voz } \\
\text { bom . não há gritaria. Os alunos têm consciência de } \\
\text { que a escola é boa e saudável, é diferente das demais } \\
\text { escolas e eles têm orgulho disso. E eles primam por } \\
\text { continuar com este trabalho, com este orgulho. Eles } \\
\text { procuram não destoar. Os alunos que se desviam, } \\
\text { pedem desculpas. }\end{array}$ \\
\hline & $\begin{array}{l}\text { 2.5. Relaçóes de reciprocidade entre uma boa } \\
\text { escola e uma escola saudável } \\
\text { 2.5.1. Nem sempre uma boa escola é uma escola } \\
\text { saudável }\end{array}$ & $\begin{array}{l}\text { Eu quero deixar claro que nem toda escola que é boa é } \\
\text { saudável como esta...tem uma escola em Carapicuiba } \\
\text { que aos olhos da comunidade é uma escola boa. Só } \\
\text { que eu não a vejo como saudável. Por quê? Porque a } \\
\text { escola age com discriminação, em algumas situações. } \\
\text { E onde houver discriminação, não existe o saudável. }\end{array}$ \\
\hline & 2.5.2. Toda escola saudável é uma boa escola & $\begin{array}{l}\text { Agora, toda escola saudavel é boa porque ela tende a } \\
\text { crescer. Ela procura, insiste e para ser saudável } \\
\text { precisa ensinar bem.. }\end{array}$ \\
\hline
\end{tabular}




\begin{tabular}{|c|c|c|}
\hline \multicolumn{3}{|c|}{ DISCURSO 2 - CATEGORIAS, TEMAS, SUB-TEMAS E EXPRESSÕES CHAVE } \\
\hline CATEGORIA & TEMAS E SUB-TEMAS & $\begin{array}{r}\text { EXPRESSÕES CHAVE } \\
\end{array}$ \\
\hline \multirow[t]{3}{*}{$\begin{array}{l}\text { 3. PAPEL DA ESCOLA } \\
\text { NA AREA DA SAÚDE }\end{array}$} & $\begin{array}{l}\text { 3.1. promoção da saúde pela articulação da teoria } \\
\text { com a prática }\end{array}$ & $\begin{array}{l}\text { Eu não entendo muito bem disto, mas acho que aqui a } \\
\text { escola fala e, ao mesmo tempo, mostra o que é saúde. } \\
\text { É necessário manter a escola limpa ...e a escola é } \\
\text { muito limpa... é preciso ter hábitos pessoais de higiene } \\
\text {...e os alunos mais novinhos que precisam aprender } \\
\text { estes hábitos aqui, aprendem ...aprendem a tomar } \\
\text { banho, a escovar dentes .... tomam flúor. A escola } \\
\text { também ensina como limpar, porque limpar - esta } \\
\text { coisa de micróbios, por exemplo. Então eles tem a } \\
\text { prática, eles vêem as coisas e a teoria. }\end{array}$ \\
\hline & $\begin{array}{l}\text { 3.2. transmissão de conhecimentos e de } \\
\text { referências no campo da saúde }\end{array}$ & $\begin{array}{l}\text { Eu acredito que a escola desenvolve um bom trabalho } \\
\text { de saúde divulgando conhecimentos e tudo o que é } \\
\text { informação de saúde. Tenho percebido que isto } \\
\text { acontece em todos os projetos que a escola trabalha, } \\
\text { em vários componentes curriculares, na área de } \\
\text { ciências, biologia, sociologia, nas relações humanas... } \\
\text { tudo isto é trabalhado pela escola com a comunidade. }\end{array}$ \\
\hline & 3.3. orientação de pais & $\begin{array}{l}\text { Acho que em matéria de saúde a escola orienta até os } \\
\text { pais que precisam, pois eles estão sempre aqui. Eles } \\
\text { participam das palestras sobre AIDS, das atividades } \\
\text { do Agita São Paulo... }\end{array}$ \\
\hline
\end{tabular}




\begin{tabular}{|c|c|c|}
\hline \multicolumn{3}{|c|}{ DISCURSO 2 - CATEGORIAS, TEMAS, SUB-TEMAS E EXPRESSÕES CHAVE } \\
\hline CATEGORIA & TEMAS E SUB-TEMAS & EXPRESSŌES CHAVE \\
\hline $\begin{array}{l}\text { 3. PAPEL DA ESCOLA } \\
\text { NA ÁREA DA SAÚDE }\end{array}$ & 3.3. formação de valores & $\begin{array}{l}\text { Como eu já disse, esta escola trabalha muito com a } \\
\text { formação de valores e acho que por isto seu trabalho é } \\
\text { bom. Os alunos que chegam de outros bairros acabam } \\
\text { incorporando estes valores. Você deve ter percebido } \\
\text { que esta é uma escola muito limpa, como eu já disse. } \\
\text { Eu vi uma cena de duas menininhas sentadas no } \\
\text { intervalo, tomando lanche no refeitório. Então me } \\
\text { chamou a atenção o aspecto organizacional delas. A } \\
\text { lancheira estava aberta. Dentro da lancheira, eu } \\
\text { percebi que havia compartimentos do lanche, do suco. } \\
\text { Então. tudo isto demonstra que há valores } \\
\text { relacionados à limpeza, à organização ..e isto estimula } \\
\text { os alunos. Outro fato - os alunos estavam andando, um } \\
\text { ou outro correndo e era hora de intervalo. Então você } \\
\text { percebe que isto chama a atenção? Os professores têm } \\
\text { uma fala e uma maneira especial de se dirigir as } \\
\text { pessoas ...eles respeitam as pessoas e tudo isto chama } \\
\text { a atenção. }\end{array}$ \\
\hline \multirow[t]{2}{*}{$\begin{array}{l}\text { 4. CARACTERISTICAS } \\
\text { DO PROCESSO DE } \\
\text { CONSTRUCÃO DE UMA } \\
\text { ESCOLA SAUDÁVEL }\end{array}$} & $\begin{array}{l}\text { 4.1. Tempo de construção de uma escola } \\
\text { saudável } \\
\text { 4.1.1. Tempo é previsível. em torno de dois a três } \\
\text { anos }\end{array}$ & $\begin{array}{l}\text { A grosso modo, acho que levaria uns dois ou três anos } \\
\text { para que a escola se torne saudável. Eu já fui diretor } \\
\text { de escola. Fiquei dez anos numa escola. A gente não } \\
\text { chegou a esse estágio, ao nivel desta escola., mas } \\
\text { fizemos muita coisa que melhorou a escola. Mas } \\
\text { sempre é um processo longo. }\end{array}$ \\
\hline & $\begin{array}{l}\text { 4.2. Condições essenciais para a construção de } \\
\text { uma escola saudavel } \\
\text { 4.2.1. Vontade de querer fazer }\end{array}$ & $\begin{array}{l}\text { O primeiro passo seria a vontade de querer fazer do } \\
\text { dirigente, dos pais, do pessoal de apoio, do vice- } \\
\text { diretor, dos coordenadores. }\end{array}$ \\
\hline
\end{tabular}




\begin{tabular}{|c|c|c|}
\hline \multicolumn{3}{|c|}{ DISCURSO 2 - CATEGORIAS, TEMAS, SUB-TEMAS E EXPRESSÕES CHAVE } \\
\hline CATEGORIA & TEMAS E SUB-TEMAS & EXPRESSŌES CHAVE \\
\hline \multirow[t]{3}{*}{$\begin{array}{l}\text { 4. CARACTERISTICAS } \\
\text { DO PROCESSO DE } \\
\text { CONSTRUÇÃO DE UMA } \\
\text { ESCOLA SAUDÁVEL }\end{array}$} & $\begin{array}{l}\text { 4.2.2. Processo compartilhado entre todos, } \\
\text { inclusive com a comunidade }\end{array}$ & $\begin{array}{l}\text { É preciso reunir os professores, reunir a comunidade } \\
\text { constantemente - que é o que esta escola faz. E a } \\
\text { comunidade, aos poucos, vai assumindo a escola } \\
\text { Então, seria um trabalho paulatino, sem nunca } \\
\text { esmorecer. }\end{array}$ \\
\hline & $\begin{array}{l}\text { 4.2.6. Projeto da escola comprometido com } \\
\text { desenvolvimento de valores }\end{array}$ & $\begin{array}{l}\text { Precisa estimular toda hora e cobrar sempre. Eu me } \\
\text { lembro, quando fui diretor de escola, da fala de um } \\
\text { professor de Educação Fisica - ele falava: "Professor. } \\
\text { outra vez este discurso"? Então, isso é uma constante. } \\
\text { É preciso repetir isso o tempo todo. Para que a escola } \\
\text { assuma isso...para que os professores assumam ...para } \\
\text { que a comunidade assuma e, por tabela, para que os } \\
\text { alunos assumam todos estes valores. É um trabalho a } \\
\text { longo prazo. } \\
\text { Para a escola ser saudável precisa desenvolver } \\
\text { valores. Eu tenho } 51 \text { anos ...e eu respeito estes valores } \\
\text { de organização, de respeitabilidade, de se dirigir às } \\
\text { outras pessoas, maneira de se comportar, de estar bem } \\
\text { vestido. }\end{array}$ \\
\hline & $\begin{array}{l}\text { 4.3. Contribuição pessoal para que a escola seja } \\
\text { saudável } \\
4.3 .1 \text { estimular a escola }\end{array}$ & $\begin{array}{l}\text { Eu tenho incentivado, nas minhas visitas, tenho feito } \\
\text { sempre o discurso de que a escola tem que caminhar } \\
\text { no sentido de ser uma escola cada vez melhor e mais } \\
\text { saudável }\end{array}$ \\
\hline
\end{tabular}




\begin{tabular}{|l|l|l|}
\hline \multicolumn{2}{|c|}{ DISCURSO 2 - CATEGORIAS, TEMAS, SUB-TEMAS E EXPRESSÕES CHAVE } \\
\hline CATEGORIA & \multicolumn{1}{|c|}{ TEMAS SUB-TEMAS } & \multicolumn{1}{|c|}{ EXPRESSÕES CHAVE } \\
\hline $\begin{array}{l}\text { 4. CARACTERISTICAS } \\
\text { DO PROCESSO DE } \\
\text { CONSTRUÇÄO DE UMA } \\
\text { ESCOLA SAUDÁVEL }\end{array}$ & $\begin{array}{l}\text { 4.3.2. incentivar a escola para que trabalhe } \\
\text { articuladamente com a comunidade }\end{array}$ & $\begin{array}{l}\text { Bato sempre na mesma tecla ...a escola tem que } \\
\text { trabalhar com a comunidade, fazer com que a } \\
\text { comunidade assuma a escola. para que o trabalho da } \\
\text { diretora e ate do corpo docente fique amenizado. } \\
\text { Porque quando a comunidade assume a escola e os } \\
\text { alunos incorporam todos estes valores, o traballo do } \\
\text { diretor e do corpo docente é um trabalho mais } \\
\text { tranquiilo, mais ameno. Nas minhas visitas, tenho } \\
\text { estimulado para que a escola abra as portas para a } \\
\text { comunidade, mas com trabalho, com organização. } \\
\text { Não somente abrir as portas e deixar para que a escola } \\
\text { fique à mercê da comunidade. Não é isso mesmo? } \\
\text { Tem que ser um trabalho direcionado. }\end{array}$ \\
\hline
\end{tabular}




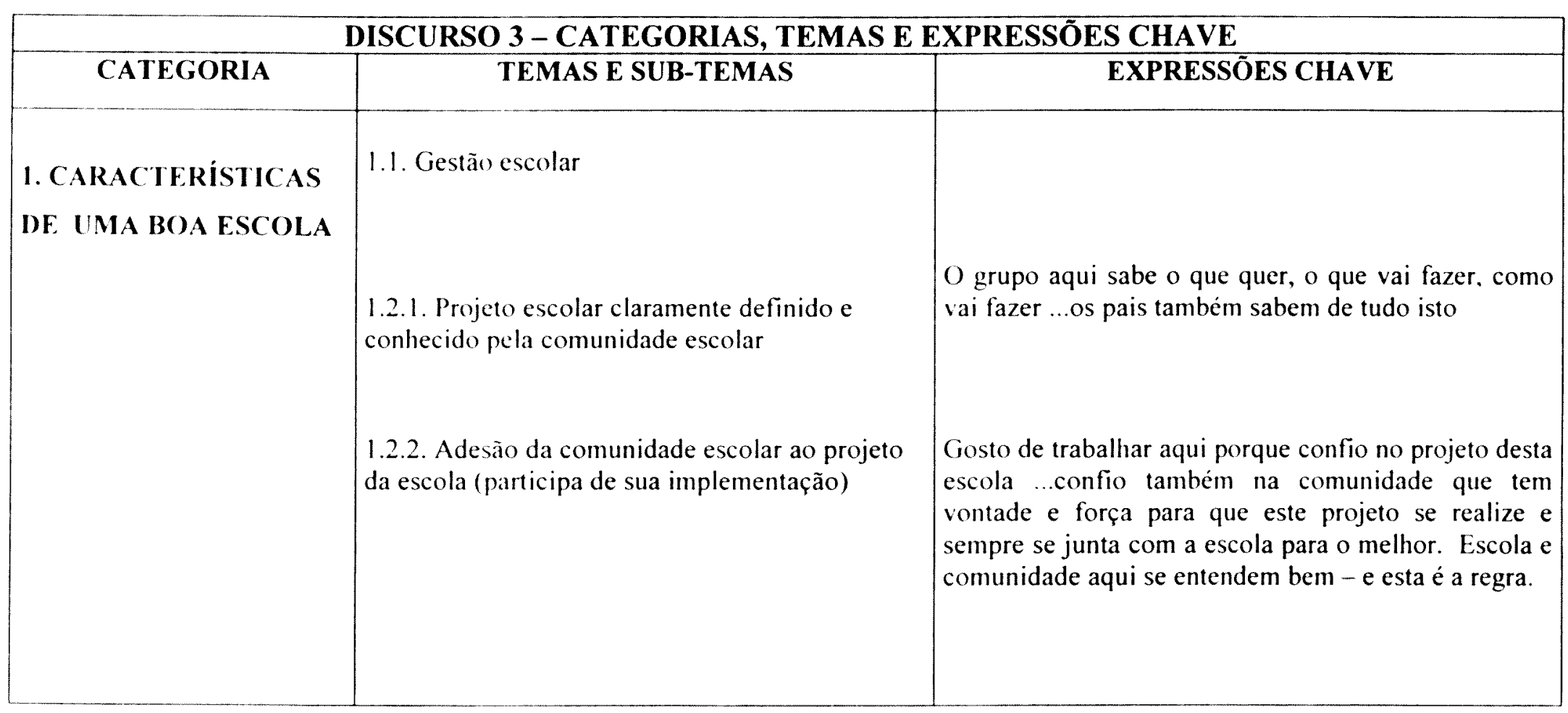




\begin{tabular}{|c|c|c|}
\hline \multicolumn{3}{|c|}{ DISCURSO 3 - CATEGORIAS, TEMAS E EXPRESSÕES CHAVE } \\
\hline CATEGORIA & TEMAS E SUB-TEMAS & EXPRESSÕES CHAVE \\
\hline \multirow[t]{2}{*}{$\begin{array}{l}\text { 1. CARACTERÍSTICAS } \\
\text { DE UMA BOA ESCOLA }\end{array}$} & $\begin{array}{l}\text { 1.2.3. Direção contribui para elevar auto-estima } \\
\text { dos professores }\end{array}$ & $\begin{array}{l}\text { Eu estava completamente para baixo em relação às } \\
\text { atribuições, de ter somente quatro aulas. Cheguei aqui } \\
\text { quase chorando de desespero e aí, a diretora me } \\
\text { animou para continuar o projeto das aulas eventuais } \\
\text {.Numa } 5 \text { série, a diretora falou: "Você vai entrar na } \\
\text { sala de aula!" Eu falei: "Não, não vou entrar ". Ai, a } \\
\text { vice veio e falou: "Pelo amor de Deus, entra!" E } \\
\text { quando eu cheguei na sala, a molecada já estava } \\
\text { gritando meu nome, já estava me esperando. Uma } \\
\text { direção assim estimula os professores e faz a escola } \\
\text { andar. A direção desta escola sempre eleva a auto- } \\
\text { estima dos professores. Pensa bem - eu sou uma } \\
\text { pessoa que fiz cinco anos e meio de faculdade, dando } \\
\text { tarde e noite, pagando uma nota violenta e hoje estou } \\
\text { aqui me submetendo a trabalhar como professor } \\
\text { eventual. Na educação, as pessoas consideram o } \\
\text { eventual como um tapa-buraco. E aqui eu não sou um } \\
\text { tapa-buraco e não sou considerado um tapa-buraco por } \\
\text { ninguém. Eu tenho um projeto. Quando eu entro numa } \\
\text { sala de aula, os alunos já me conhecem. Já sabem o } \\
\text { que nós vamos trabalhar. Eles não ficam "olha, lá vem } \\
\text { aquele chato". De forma alguma... }\end{array}$ \\
\hline & $\begin{array}{l}\text { 1.2.4. Interesse e compromisso da equipe em } \\
\text { realizar um bom trabalho }\end{array}$ & $\begin{array}{l}\text { Não existe nas outras escolas o mesmo interesse que } \\
\text { existe aqui ...tenho sempre a impressão de que a } \\
\text { maioria quer que esta escola seja cada vez melhor }\end{array}$ \\
\hline
\end{tabular}




\begin{tabular}{|c|c|c|}
\hline \multicolumn{3}{|c|}{ DISCURSO 3 - CATEGORIAS, TEMAS E EXPRESSÕES CHAVE } \\
\hline CATEGORIA & TEMAS E SUB-TEMAS & EXPRESSÕES CHAVE \\
\hline $\begin{array}{l}\text { 1. CARACTERISTICAS } \\
\text { DE UMA BOA ESCOLA }\end{array}$ & $\begin{array}{l}\text { 1.2.5. Bom entrosamento entre os elementos da } \\
\text { equipe }\end{array}$ & $\begin{array}{l}\text { Eu noto que não existe nas outras escolas uma } \\
\text { integração entre as pessoas, como existe aqui. Ontem } \\
\text { fui a uma escola que é bem avaliada em Cotia ...e eu } \\
\text { não consegui perceber que as pessoas estavam } \\
\text { integradas.. eu não me senti bem lá e desisti logo. }\end{array}$ \\
\hline \multirow[t]{4}{*}{$\begin{array}{l}\text { 2. CARACTERISTICAS } \\
\text { DE UMA ESCOLA } \\
\text { SAUDÁVEL }\end{array}$} & $\begin{array}{l}\text { 2.1. Estrutura e ambiente fisico de boa qualidade } \\
\text { (espaço adequado, arborização) }\end{array}$ & $\begin{array}{l}\text { E uma escola muito saudável. } \dot{E} \text { uma escola limpa } \\
\text {...caso a gente fosse fazer um giro pela escola, notaria } \\
\text { que a escola em geral, o espaço fisico, as árvores, as } \\
\text { pessoas, a biblioteca, as salas de aula, o pátio .... e é } \\
\text { tudo tão bonito e saudável! }\end{array}$ \\
\hline & $\begin{array}{l}\text { 2.2. Ambientes e/ou espaços da escola } \\
\text { particularmente saudáveis } \\
\text { 2.2.1. pátio escolar espaçoso, arejado e florido }\end{array}$ & $\begin{array}{l}\text { O pátio da escola é uma maravilha ...espaçoso. } \\
\text { arejado. Coberto, cercado por flores ....parece aquela } \\
\text { definição de ilha ...em vez de água por todos os lados. } \\
\text { são flores por todos os lados }\end{array}$ \\
\hline & $\begin{array}{l}\text { 2.3. Gestão escolar } \\
\text { 2.3.1. Clima amigável e boa organização geral }\end{array}$ & $\begin{array}{l}\text { É uma escola bem organizada e de alto austral ....as } \\
\text { pessoas são felizes aqui e isto é um sintoma de que as } \\
\text { coisas por aqui são saudáveis. }\end{array}$ \\
\hline & $\begin{array}{l}\text { 2.3.2. Preocupação com a qualidade de vida das } \\
\text { pessoas que vivem na escola }\end{array}$ & $\begin{array}{l}\text { Os professores daqui se preocupam com a } \\
\text { comunidade e todo mundo pensa no bem estar de } \\
\text { todos. Não só do corpo docente, mas também dos } \\
\text { funcionários, dos alunos, em todos os aspectos. Não } \\
\text { só na ausência da saúde ou na doença, mas no estado } \\
\text { social das pessoas que se encontram na comunidade. } \\
\text { Se cu fosse dar uma nota para esta escola, de zero a } \\
\text { dez, eu tocava ela em } 9,5 \text {. }\end{array}$ \\
\hline
\end{tabular}




\begin{tabular}{|c|c|c|}
\hline \multicolumn{3}{|c|}{ DISCURSO 3 - CATEGORIAS, TEMAS E EXPRESSŌES CHAVE } \\
\hline CATEGORIA & TEMAS E SUB-TEMAS & EXPRESSÕES CHAVE \\
\hline $\begin{array}{l}\text { 2. CARACTERISTICAS } \\
\text { DE UMA ESCOLA } \\
\text { SAUDÁVEL }\end{array}$ & $\begin{array}{l}\text { 2.5. Relaçóes de reciprocidade entre uma boa } \\
\text { escola e uma escola saudável } \\
\text { 2.5.1. Toda escola saudável é uma boa escola }\end{array}$ & $\begin{array}{l}\text { Depois de tudo isto que eu falei, acho que uma escola } \\
\text { que é saudável tem também que ser boa , tem que } \\
\text { fazer o aluno aprender ...pois a educação não é um dos } \\
\text { requisitos da saúde? }\end{array}$ \\
\hline \multirow[t]{5}{*}{$\begin{array}{l}\text { 3. PAPEL DA ESCOLA } \\
\text { NA AREA DA SAÚDE }\end{array}$} & $\begin{array}{l}\text { 3.1. promoção da saúde pela articulação da teoria } \\
\text { com a prática }\end{array}$ & $\begin{array}{l}\text { Acho que o papel da escola é promover a saúde e não } \\
\text { apenas trabalhar a questão da doença. Precisa falar de } \\
\text { higiene e estar numa escola limpa ...falar de escola } \\
\text { saudável e estar estudando numa boa escola saudável }\end{array}$ \\
\hline & $\begin{array}{l}\text { 3.2. transmissão de conhecimentos e de } \\
\text { referencias no campo da saúde }\end{array}$ & $\begin{array}{l}\text { A escola tem que informar mesmo.. não é só isso, mas } \\
\text { é também isto }\end{array}$ \\
\hline & 3.3. orientação de pais & $\begin{array}{l}\text { Em muitos casos, os pais sĩo orientados pela escola } \\
\text { em muitos aspectos .... sobre hábitos de higiene, sobre } \\
\text { doenças sexualmente transmissiveis, sobre os } \\
\text { problemas dos filhos adolescentes }\end{array}$ \\
\hline & 3.4. orientação de alunos & $\begin{array}{l}\text { Acho que o papel da escola é estar orientando os } \\
\text { alunos, em todos os aspectos. Orientar é mais que } \\
\text { informar....é dar as dicas de como eles podem usar as } \\
\text { informações ...ainda não se pode jurar que eles vão } \\
\text { fazer, mas é papel da escola. }\end{array}$ \\
\hline & 3.6 formação de valores & $\begin{array}{l}\text { Acho que o papel da escola é trabalhar também com } \\
\text { valores Aqui, por exemplo, nós trabalhamos com } \\
\text { projetos nas aulas eventuais : cidadania e participação, } \\
\text { nas } 5 \text { as. e 6as. séries, preconceito e solidariedade, nas } \\
\text { 7as. e 8as. séries: sexualidade e preconceito, na } 1 \\
\text { série do Ensino Médio, ética, no } 2^{\circ} \text { ano e diversidade } \\
\text { cultural, na } 3 \text { série. Estas questões envolvem valores } \\
\text { e eles precisam ser discutidos }\end{array}$ \\
\hline
\end{tabular}




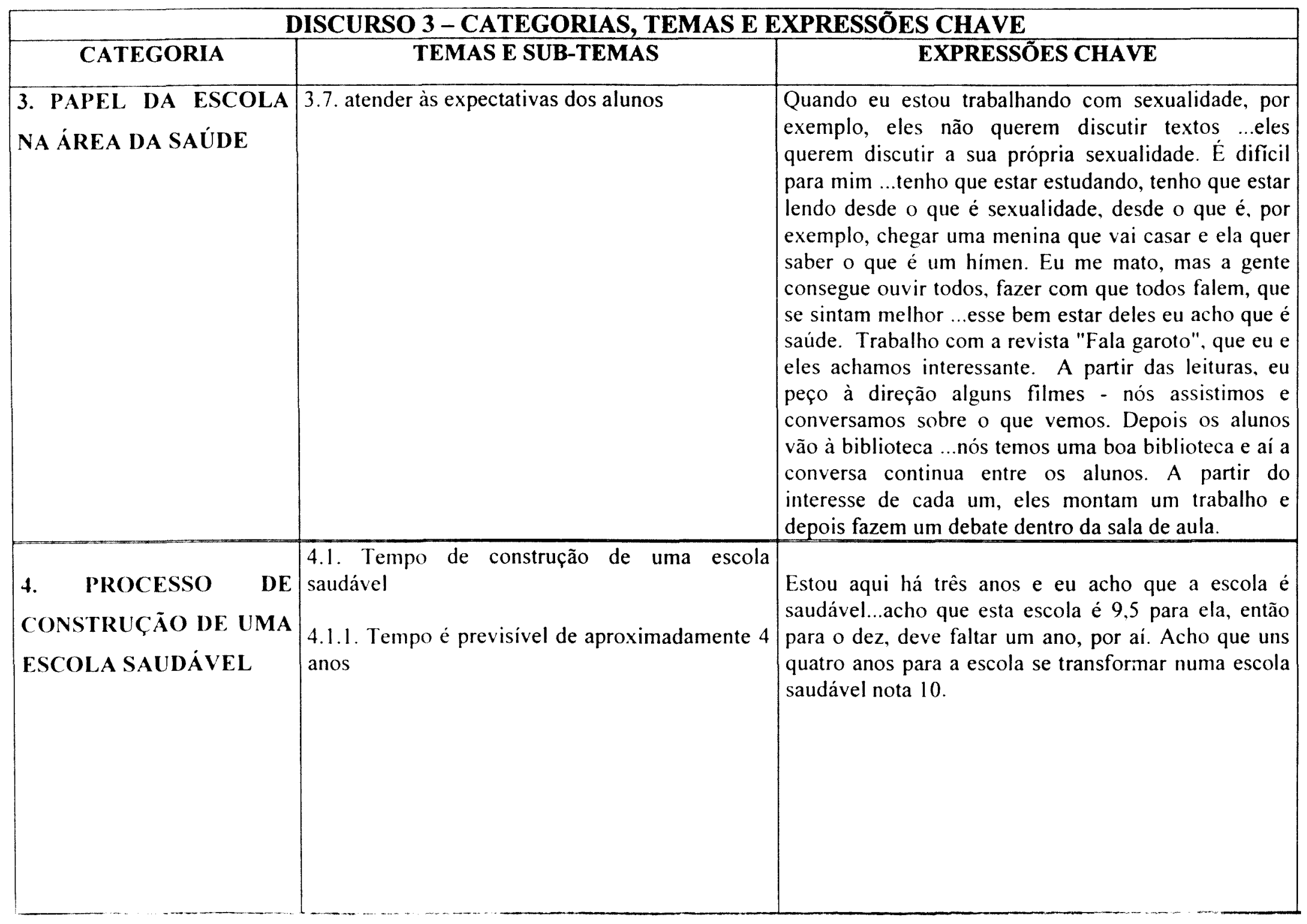




\begin{tabular}{|c|c|c|}
\hline \multicolumn{3}{|c|}{ DISCURSO 3 - CATEGORIAS, TEMAS E EXPRESSÕES CHAVE } \\
\hline \multirow{4}{*}{$\begin{array}{l}\text { 4. PROCESSO DE } \\
\text { CONSTRUÇÃO DE UMA } \\
\text { ESCOLA SAUDÁVEL }\end{array}$} & TEMAS E SUB-TEMAS & EXPRESSÕES CHAVE \\
\hline & $\begin{array}{l}\text { 4.2. Condições essenciais para a construção de } \\
\text { uma escola saudável }\end{array}$ & \\
\hline & $\begin{array}{l}\text { 4.2.1. Processo compartilhado entre todos, } \\
\text { inclusive com a comunidade }\end{array}$ & $\begin{array}{l}\text { Para a escola se transformar numa escola saudável é } \\
\text { preciso um trabalho coletivo - acho que isto é } \\
\text { essencial ...e coletivo não é apenas juntar o povo da } \\
\text { escola ...é trazer a comunidade para dentro da escola, } \\
\text { como esta faz e faz bem. }\end{array}$ \\
\hline & 4.2.2. Autonomia da escola & $\begin{array}{l}\text { A liberdade, a autonomia. Eu considero esta escola } \\
\text { saudável porque existe liberdade para nós } \\
\text { trabalharmos e para o aluno pesquisar, estudar e } \\
\text { perguntar tudo o que quiserem. E nós devemos centrar } \\
\text { nosso trabalho nisto - na liberdade. É claro que toda } \\
\text { liberdade tem que ser um pouco controlada, porque } \\
\text { são as normas que sustentam as relações entre as } \\
\text { pessoas, mas falar em projeto de escola sem } \\
\text { autonomia e sem responsabilidade não está com nada }\end{array}$ \\
\hline
\end{tabular}




\begin{tabular}{|c|c|c|}
\hline \multicolumn{3}{|c|}{ DISCURSO 3 - CATEGORIAS, TEMAS E EXPRESSÕES CHAVE } \\
\hline CATEGORIA & TEMAS E SUB-TEMAS & EXPRESSÕES CHAVE \\
\hline $\begin{array}{l}\text { 4. PROCESSO DE } \\
\text { CONSTRUÇÃO DE UMA } \\
\text { ESCOLA SAUDÁVEL }\end{array}$ & $\begin{array}{l}\text { 4.2.3. Profissionais precisam acreditar no novo, } \\
\text { em si mesmos, na comunidade e na equipe e criar } \\
\text { um clima de amizade }\end{array}$ & $\begin{array}{l}\text { As pessoas precisam acreditar em si e nos outros. Eu } \\
\text { acho que em alguns momentos as pessoas me julgam } \\
\text { um bobo ou um "puxa-saco". Mas eu acredito na } \\
\text { comunidade e acredito na escola. Para integrar o } \\
\text { pessoal da escola precisa de amizade. A amizade é o } \\
\text { principal. Acho que é a questão da amizade. Acho que } \\
\text { as pessoas chegam na escola com receio, com muitos } \\
\text { tabus. Acho que cada lugar é um lugar. Cada lugar } \\
\text { tem sua realidade. E as pessoas só acreditam naquilo } \\
\text { que elas já vivenciaram... elas não acreditam no novo. } \\
\text { Então, numa amizade, você vai mostrando às pessoas } \\
\text { como as coisas são feitas, como as coisas são } \\
\text { constituidas. E as pessoas começam a se abrir um } \\
\text { pouco mais. Elas chegam presas. Então quando vocêe } \\
\text { vai chegando mais nas pessoas, elas vão se soltando. } \\
\text { As pessoas ficam assustadas de inicio. Eu estou } \\
\text { presenciando isto agora. Tem pessoas ai que estão } \\
\text { com a cara que parece ... Mas com o tempo vai } \\
\text { mudando. }\end{array}$ \\
\hline
\end{tabular}




\begin{tabular}{|c|c|c|}
\hline \multicolumn{3}{|c|}{ DISCURSO 3 - CATEGORIAS, TEMAS E EXPRESSÕES CHAVE } \\
\hline CATEGORIA & TEMAS E SUB-TEMAS & EXPRESSÕES CHAVE \\
\hline \multirow[t]{2}{*}{$\begin{array}{l}\text { 4. PROCESSO DE } \\
\text { CONSTRUÇÃO DE UMA } \\
\text { ESCOLA SAUDÁVEL }\end{array}$} & $\begin{array}{l}\text { 4.4. Contribuição pessoal } \\
\text { 4.4.1. disponibilidade para o diálogo }\end{array}$ & $\begin{array}{l}\text { acho que a minha participação é sempre estar } \\
\text { conversando com os alunos, com os colegas...é } \\
\text { sempre estar pronto para bater papo. Quando eu estou } \\
\text { mal, eles percebem. Ȧs vezes eu chego brincando na } \\
\text { sala de aula e eles percebem : "você não está legal } \\
\text { hoje". Eu acho muito doido quando chego na sala de } \\
\text { aula e percebo que um aluno meu não está bem! Por } \\
\text { exemplo, ver um aluno de } 8^{\circ} \text { ou do Ensino Médio } \\
\text { desabar na minha frente. Só vejo uma maneira de } \\
\text { entrar na sala de aula - só entro quando estão todos } \\
\text { sentados. Pode ser } 5^{\circ} \text { série ou pode ser } 3^{\circ} \text { colegial. } \\
\text { Quando alguém não está bem, eu pergunto e converso } \\
\text { sempre. Eu acho mesmo que a minha participação é a } \\
\text { minha disposição para o diálogo. }\end{array}$ \\
\hline & $\begin{array}{l}\text { 4.5. Receio quanto à descontinuidade do projeto } \\
\text { da escola }\end{array}$ & $\begin{array}{l}\text { A integração demora porque a educação passa por } \\
\text { mudanças todo ano. E nisso, todo trabalho é quebrado } \\
\text { e você vai de novo colocando aquele tijolinho. Ai, } \\
\text { cliega no final do ano - quebra. Sempre ficam } \\
\text { algumas pessoas. E você consegue construir. E dá } \\
\text { uma quebrada, mas você vai moldando de novo. Mas } \\
\text { podia ser mais fácil ...a gente sempre fica com medo } \\
\text { do que vai acontecer no próximo ano, se a equipe vai } \\
\text { continuar na escola... }\end{array}$ \\
\hline
\end{tabular}




\begin{tabular}{|c|c|c|}
\hline \multicolumn{3}{|c|}{ DISCURSO 4 - CATEGORIAS, TEMAS E EXPRESSÕES CHAVE } \\
\hline CATEGORIA & TEMAS E SUB-TEMAS & EXPRESSÕES CHAVE \\
\hline \multirow[t]{2}{*}{$\begin{array}{l}\text { 1. CARACTERÍSTICAS } \\
\text { DE UMA BOA ESCOLA }\end{array}$} & $\begin{array}{l}\text { 1.1. Estrutura e ambiente fisico de boa qualidade } \\
\text { (escola limpa, equipada, funcional e agradável) }\end{array}$ & $\begin{array}{l}\text { Acho que é óbvio que uma boa escola precisa ser } \\
\text { limpa, ter equipamentos em ordem, funcionar } \\
\text { adequadamente ...ser agradável aos olhos, } \\
\text { impressionar bem os alunos e a comunidade. É isto } \\
\text { que acontece com o Fornasaro. }\end{array}$ \\
\hline & $\begin{array}{l}\text { 1.2. Gestão escolar } \\
\text { 1.2.1. Projeto escolar claramente definido e } \\
\text { conhecido pela comunidade escolar } \\
\text { 1.2.2. Adesão da comunidade escolar ao projeto } \\
\text { da escola (participa de sua implementação) }\end{array}$ & $\begin{array}{l}\text { A escola é boa porque a gente sabe o que quer. Não } \\
\text { digo que não poderíamos querer outra coisa melhor, } \\
\text { mas a comunidade conhece e aprova o nosso projeto. } \\
\text { Não dá para improvisar em educação - tem que } \\
\text { planejar, tem que ter objetivo, tem que chegar a algum } \\
\text { lugar, tem que corrigir rumos, tem que rever, tem que } \\
\text { fazer de novo. } \\
\text { A comunidade participa muito - ela é nossa parceira } \\
\text { de todas as horas. A escola tem um excelente } \\
\text { relacionamento com a comunidade. É raro o final de } \\
\text { semana que a escola não está aberta ...a comunidade } \\
\text { se responsabiliza por tudo e nunca tivemos nenhum } \\
\text { problema. Como moro aqui perto, inclusive muitos } \\
\text { pais de alunos ficaram meus amigos pessoais. A } \\
\text { escola conta com eles e eles com a escola - a escola é } \\
\text { nossa...nós somos a comunidade }\end{array}$ \\
\hline
\end{tabular}




\begin{tabular}{|c|c|c|}
\hline \multicolumn{3}{|c|}{ DISCURSO 4 - CATEGORIAS, TEMAS E EXPRESSÕES CHAVE } \\
\hline CATEGORIA & TEMAS E SUB-TEMAS & EXPRESSÕES CHAVE \\
\hline $\begin{array}{l}\text { 1. CARACTERISTICAS } \\
\text { DE UMA BOA ESCOLA }\end{array}$ & $\begin{array}{l}\text { 1.2.3. Escola historicamente comprometida com } \\
\text { a melhoria da qualidade }\end{array}$ & $\begin{array}{l}\text { Esta escola tem uma história de sempre buscar ser } \\
\text { uma boa escola ...ela tem } 25 \text { anos, foi fundada por } \\
\text { italianos que trabalhavam numa tecelagem aqui perto. } \\
\text { Mesmo com as mudanças na educação, a comunidade } \\
\text { daqui sabe muito bem o que quer da escola e } \\
\text { influencia o que acontece aqui dentro. }\end{array}$ \\
\hline & $\begin{array}{l}\text { 1.2.4. Interesse e compromisso da equipe em } \\
\text { realizar um bom trabalho }\end{array}$ & $\begin{array}{l}\text { A equipe é bastante interessada e comprometida. Nas } \\
\text { horas de trabalho coletivo todos participam para } \\
\text { aperfeiçoar o nosso trabalho ...até os professores } \\
\text { eventuais participam das horas de trabalho coletivo e } \\
\text { olhe que eles não recebem por este horário de } \\
\text { planejamento. Eles contam para os professores o que } \\
\text { os seus alunos estão produzindo nas aulas em que eles } \\
\text { faltaram, dão informações sobre aspectos da } \\
\text { personalidade dos alunos que os professores nem } \\
\text { conhecem.. }\end{array}$ \\
\hline & 1.3. Qualidade de ensino & \\
\hline
\end{tabular}




\begin{tabular}{|c|c|l|}
\hline \multicolumn{2}{|c|}{ DISCURSO 4-CATEGORIAS, TEMAS E EXPRESSÕES CHAVE } \\
\hline CATEGORIA & \multicolumn{1}{|c|}{ TEMAS E SUB-TEMAS } & \multicolumn{1}{c|}{ EXPRESSÓES CHAVE } \\
\hline DE UMA BOA ESCOLA & 1.3.1. otimização do tempo pedagógico & $\begin{array}{l}\text { Nós queremos aproveitar ao máximo o tempo que o } \\
\text { aluno fica na escola. Por exemplo, com as aulas dos } \\
\text { professores eventuais, nós conseguimos melhorar } \\
\text { muito: nós valorizamos a aula eventual. O professor } \\
\text { precisa faltar - é inadiável. Então nós montamos um } \\
\text { projeto em cima dos temas transversais: cidadania, } \\
\text { ética, sexualidade, saúde. Os professores eventuais } \\
\text { consultam as classes . preparam as aulas sobre os } \\
\text { temas que os alunos escolheram e quando algum } \\
\text { professor falta, as turmas discutem estes temas com os } \\
\text { professores eventuais. Antigamente, quando havia } \\
\text { falta, os alunos diziam: “Oba, aula vaga”. Eram } \\
\text { horas perdidas. Agora, não - são momentos ricos, não } \\
\text { pára o trabalho. Tem um trabalho preparado, pronto } \\
\text { para ser discutido com os alunos. Entra um } \\
\text { professor, uma pedagoga, enfim, alguém que sabe o } \\
\text { que fazer e que não vai só tomar conta de uma classe. } \\
\text { Sempre se faz uma dinâmica interessante . Não se } \\
\text { perde tempo - nas salas onde se precisa entrosar os } \\
\text { adolescentes, prepara-se uma estratégia para trabalhar } \\
\text { nesta direção. Tivemos um problema numa classe em } \\
\text { que uma menina estava roubando - preparamos uma } \\
\text { discussão sobre isso e na primeira aula vaga, o tema } \\
\text { foi discutido com a classe. }\end{array}$ \\
& \\
&
\end{tabular}




\begin{tabular}{|c|c|c|}
\hline \multicolumn{3}{|c|}{ DISCURSO 4 - CATEGORIAS, TEMAS E EXPRESSÕES CHAVE } \\
\hline CATEGORIA & TEMAS E SUB-TEMAS & EXPRESSṌES CHAVE \\
\hline $\begin{array}{l}\text { 1. CARACTERÍSTICAS } \\
\text { DE UMA BOA ESCOLA }\end{array}$ & $\begin{array}{l}\text { 1.3.2. diversificação das atividades de ensino e } \\
\text { aprendizagem e utilização de recursos didático- } \\
\text { pedagógicos } \\
\text { 1.3.3. formação continuada dos professoras nas } \\
\text { horas de trabalho pedagógico, como estratégia } \\
\text { para melhorar a qualidade das aulas. }\end{array}$ & $\begin{array}{l}\text { Os professores usam muitos vídeos ...a nossa } \\
\text { videoteca é boa...gravamos os programas da TV } \\
\text { escola, compramos outros vídeos com recursos na } \\
\text { APM, emprestamos na Oficina Pedagógica ...se } \\
\text { precisamos de algum filme e não achamos em lugar } \\
\text { nenhum, compramos e usamos. Material aqui não é } \\
\text { para ficar guardado. É tudo planejado...não dá para ser } \\
\text { coisa de última hora No ano passado, o professor } \\
\text { eventual trabalhou com rap - eles dançaram, } \\
\text { analisaram a letra, fizeram outra, criaram novas } \\
\text { músicas. A aula sempre que ter amarrada num } \\
\text { objetivo . O professor que coordenava o projeto de } \\
\text { aulas eventuais é aplaudido pelos alunos ...eu não } \\
\text { quero que ele se afaste daqui, porque ele é importante } \\
\text { para a escola. Ele dá quatro aulas aqui ...no resto do } \\
\text { tempo, ele é eventual. } \\
\text { As nossas Horas de Trabalho Coletivo viram horas de } \\
\text { capacitação, pois as pessoas trocam experiências, } \\
\text { aprendem uns com os outros. Assim, muita gente } \\
\text { perde o medo de tentar fazer alguma coisa boa que já } \\
\text { deu certo, elas crescem profissionalmente e a equipe } \\
\text { fica mais fortalecida. As aulas ficam mais ricas e } \\
\text { todos ganhamos com isso. }\end{array}$ \\
\hline $\begin{array}{l}\text { 2. CARACTERÍSTICAS } \\
\text { DE UMA ESCOLA } \\
\text { SAUDÄVEL }\end{array}$ & 2.1 Gestão escolar & \\
\hline
\end{tabular}




\begin{tabular}{|c|c|c|}
\hline \multicolumn{3}{|c|}{ DISCURSO 4 - CATEGORIAS, TEMAS E EXPRESSÕES CHAVE } \\
\hline CATEGORIA & TEMAS E SUB-TEMAS & EXPRESSÕES CHAVE \\
\hline \multirow[t]{4}{*}{$\begin{array}{l}\text { 2. CARACTERÍSTICAS } \\
\text { DE UMA ESCOLA } \\
\text { SAUDÁVEL }\end{array}$} & 2.1.1. Clima amigável e boa organização geral & $\begin{array}{l}\text { Esta escola é muito saudável. Ela é organizada ...tem } \\
\text { que ser limpa, tem que funcionar, tem que fazer o seu } \\
\text { papel de escola - conseguir ensinar. Tem que dialogar } \\
\text { muito com os alunos ...acho que conseguimos muito } \\
\text { isso ..é um pouco dificil, mas com o tempo isto vai } \\
\text { virando uma boa rotina. Tem que ter uma equipe } \\
\text { integrada ...que sabe o que tem que fazer ...tem que } \\
\text { estar afinada com a comunidade }\end{array}$ \\
\hline & $\begin{array}{l}\text { 2.2. Ensino de boa qualidade } \\
\text { 2.2.1.Foco do trabalho pedagógico é a } \\
\text { permanência do aluno na escola e sua } \\
\text { aprendizagem efetiva }\end{array}$ & $\begin{array}{l}\text { Acho que já falei muito disto, mas como sempre bato } \\
\text { nesta tecla aqui na escola, acho bom repetir. Nós nos } \\
\text { esforçamos para não desviar a nossa atenção do que } \\
\text { realmente interessa- do aluno. Trabalhamos para o } \\
\text { aluno, para que ele goste da escola, para que ele } \\
\text { melhore a sua auto-estima, para que ele tenha sucesso. }\end{array}$ \\
\hline & $\begin{array}{l}\text { 2.3. Relação de reciprocidade entre uma boa } \\
\text { escola e uma escola saudável } \\
\text { 2.3.1. Toda escola saudável é uma boa escola }\end{array}$ & $\begin{array}{l}\text { Será que a gente pode considerar saudável uma escola } \\
\text { que expulsa o aluno, que não consegue fazer com que } \\
\text { ele aprenda? Eu acho sinceramente que não e toda } \\
\text { escola saudável tem a obrigação de ser uma boa } \\
\text { escola. Aliás, penso que uma das condições para que } \\
\text { ela seja saudável é que ela seja boa. }\end{array}$ \\
\hline & $\begin{array}{l}\text { 2.3.2. Nem sempre uma boa escola é uma escola } \\
\text { saudável }\end{array}$ & $\begin{array}{l}\text { Nem sempre a escola boa é saudável. As vezes, o } \\
\text { professor vai lá e faz o seu trabalho. Para que ela seja } \\
\text { saudável, ela tem que brilhar ...o profissional tem que } \\
\text { dar a sua alma, a sua emoção. Ou eu vou e me dou por } \\
\text { inteiro ou eu não consigo fazer. Ela não só ensina, } \\
\text { mas ensina para a vida...ela não fala só do que é bom, } \\
\text { mas oferece um bom ambiente para o aluno e para } \\
\text { todos. }\end{array}$ \\
\hline
\end{tabular}




\begin{tabular}{|c|c|c|}
\hline \multicolumn{3}{|c|}{ DISCURSO 4 - CATEGORIAS, TEMAS E EXPRESSÓES CHAVE } \\
\hline CATEGORIA & TEMAS E SUB-TEMAS & EXPRESSOOES CHAVE \\
\hline $\begin{array}{l}\text { 3. PAPEL DA ESCOLA } \\
\text { NA ÁREA DA SAÚDE }\end{array}$ & 3.8. formação integral & $\begin{array}{l}\text { O papel da escola é fazer com que o aluno se tornc } \\
\text { uma pessoa, consiga viver de uma forma digna lá fora. } \\
\text { É meio antigo, mas a escola tem que dar ao aluno uma } \\
\text { formação integral. Então, nós sempre procuramos } \\
\text { fazer isto com nossos alunos. Nós não temos aqui caso } \\
\text { de professor que apanhou de aluno, de aluno que faz } \\
\text { represália ao professor. E o papel principal da escola é } \\
\text { conseguir que o aluno venha e fique na escola - numa } \\
\text { boa escola. Orientar, informar, viver aqui uma } \\
\text { experiência gostosa, boa, interessante. Aprender - é } \\
\text { por aí. }\end{array}$ \\
\hline \multirow[t]{3}{*}{$\begin{array}{l}\text { 4. CARACTERISTICAS } \\
\text { DO PROCESSO DE } \\
\text { CONSTRUÇ̃̃O DE UMA } \\
\text { ESCOLA SAUDÁVEL }\end{array}$} & $\begin{array}{l}\text { 4.1. Tempo de construção de uma escola } \\
\text { saudável } \\
\text { 4.1.1. Tempo é previsível, em torno de três anos } \\
\text { (manutenção exige trabalho continuado) }\end{array}$ & $\begin{array}{l}\text { Acho que uns três anos com uma equipe básica é um } \\
\text { bom tempo para a escola se tornar saudável ...depois, é } \\
\text { questão de sempre ir acertando o que ainda precisa } \\
\text { acertar. Manter uma escola boa e saudável é tarefa de } \\
\text { todos e da vida inteira. Até a noção do que é uma boa } \\
\text { e uma escola saudável muda com o tempo - assim, a } \\
\text { escola não pode parar. }\end{array}$ \\
\hline & $\begin{array}{l}\text { 4.2. Condições essenciais para a construção de } \\
\text { uma escola saudável } \\
\text { 4.2.1. Vontade de querer fazer }\end{array}$ & $\begin{array}{l}\text { Precisa ter vontade de fazer ...precisa acreditar que se } \\
\text { pode fazer ...mas precisa de muita paixão para isto, } \\
\text { conforme diz o Ruben Alves. }\end{array}$ \\
\hline & $\begin{array}{l}\text { 4.2.2. Processo compartilhado entre todos, } \\
\text { inclusive com a comunidade }\end{array}$ & $\begin{array}{l}\text { Para que uma escola seja boa e saudável ela precisa } \\
\text { abrir suas portas para a comunidade - precisa se abrir } \\
\text { por dentro, aparar as arestas, formar um grupo que } \\
\text { faça mesmo e convença os outros a também fazerem o } \\
\text { mesmo. Mas se abrir para fora também - repito muito, } \\
\text { mas se a escola não serve á comunidade, ela é } \\
\text { depredada, roubada, invadida. }\end{array}$ \\
\hline
\end{tabular}




\begin{tabular}{|c|c|c|}
\hline \multicolumn{3}{|c|}{ DISCURSO 4 - CATEGORIAS, TEMAS E EXPRESSÕES CHAVE } \\
\hline CATEGORIA & TEMAS E SUB-TEMAS & EXPRESSÓES CHAVE \\
\hline $\begin{array}{l}\text { 4. CARACTERÍSTICAS } \\
\text { DO PROCESSO DE } \\
\text { CONSTRUÇÃO DE UMA } \\
\text { ESCOLA SAUDÁVEL }\end{array}$ & $\begin{array}{l}\text { 4.2..3. Projeto escolar conhecido por todos que } \\
\text { define as prioridades da escola }\end{array}$ & $\begin{array}{l}\text { Precisa ter um projeto muito bem definido. De } \\
\text { avançar para que os professores, os funcionários, a } \\
\text { direção, a coordenação, os alunos e a comunidade } \\
\text { consigam definir prioridades - atender bem o aluno, } \\
\text { fazê-lo aprender, construir uma escola que seja uma } \\
\text { extensão do lar. Há necessidade de caminhar junto } \\
\text { com a comunidade, mais do que qualquer outra coisa. } \\
\text { Tem que levantar todos os problemas, mas saber o qu } \\
\text { atacar em primeiro lugar...senão, fica tudo ruim. }\end{array}$ \\
\hline & $\begin{array}{l}\text { 4.4. Contribuição pessoal } \\
\text { 4.4.1. assegurar as condições básicas que a escola } \\
\text { necessita para fazer um bom trabalho } \\
\text { (recursos humanos e materiais) }\end{array}$ & $\begin{array}{l}\text { Eu tenho que dar tudo que a escola precisa. Corro } \\
\text { atrás para que tudo fique em ordem, para que o que se } \\
\text { fez seja conservado ... administro bem os recursos, } \\
\text { sempre junto com a comunidade...acompanho o que } \\
\text { está acontecendo, dou uma mãozinha aqui e ali. . }\end{array}$ \\
\hline & $\begin{array}{l}\text { 4.4.2 acompanhar e cobrar da escola o processo } \\
\text { de se tornar uma escola saudável }\end{array}$ & $\begin{array}{l}\text { acompanho o processo, da mesma maneira que dou } \\
\text { uma mão e estimulo, também vou cobrando aqui e ali, } \\
\text { me certificando da necessidade de corrigir isto ou } \\
\text { aquilo. Até sou chata, mas este é o meu papel. }\end{array}$ \\
\hline & $\begin{array}{l}\text { 4.4.3. estimular a participação de todos e } \\
\text { contribuir para elevar a auto-estima do grupo } \\
\text { 4.4.4. presença fisica da direção na escola e } \\
\text { reconhecida competência administrativa }\end{array}$ & $\begin{array}{l}\text { Aproximo as pessoas, sistematizo as nossas } \\
\text { prioridades. Estimulo a participação de todos, busco } \\
\text { manter elevada a auto-estima de cada um e da } \\
\text { equipe...nem sempre a gente consegue, mas a gente } \\
\text { sente que é importante e corre atrás. } \\
\text { Eu estou sempre aqui - e todos sabem que podem } \\
\text { contar comigo e deixam claro que eu posso contar } \\
\text { com eles. Eu compartilho com todos a tarefa de dirigir } \\
\text { esta escola, mas assumo o meu pedaço. }\end{array}$ \\
\hline
\end{tabular}




\begin{tabular}{|l|l|l|}
\hline \multicolumn{2}{|c|}{ DISCURSO 5-CATEGORIAS, TEMAS E EXPRESSÕES CHAVE } \\
\hline \multicolumn{1}{|c|}{ CATEGORIA } & \multicolumn{1}{|c|}{ TEMAS E SUB-TEMAS } & \multicolumn{1}{c|}{ EXPRESSÕES CHAVE } \\
\hline DE UMA BOA ESCOLA & 1.1. Gestão escolar & $\begin{array}{l}\text { No planejamento do início do ano nós sempre } \\
\text { discutimos qual vai ser o lema da escola durante o } \\
\text { ano, qual será o nosso projeto, o que vamos fazer } \\
\text { como vamos fazer ...as nossas prioridades.. } \\
\text { A comunidade compra o projeto da escola ...ela } \\
\text { participa muito. Ela é parceira da escola, os pais } \\
\text { colaboram em tudo que é necessário e valorizam o } \\
\text { nosso trabalho. Nossos professores têm liberdade para } \\
\text { convocar os pais e conversar com eles, no horário que } \\
\text { for possivel. Não dá para fazer um bom trabalho se a } \\
\text { comunidade não está aqui dentro e acho que é este o o } \\
\text { nosso maior trunfo. }\end{array}$ \\
$\begin{array}{l}\text { 1.1.1. Projeto escolar claramente definido e } \\
\text { conhecido pela comunidade escolar }\end{array}$ & $\begin{array}{l}\text { 1.1.2. Adesão da comunidade escolar ao projeto } \\
\text { da escola (comunidade participa de sua } \\
\text { implementação) }\end{array}$ & $\begin{array}{l}\text { A direção é sempre muito presente. Fica o tempo todo } \\
\text { na escola e há direção em todos os periodus em que a } \\
\text { escola funciona. A diretora e os vice sabem o que têm } \\
\text { que fazer e fazem. Elas são muito entrosadas entre } \\
\text { elas e isto ajuda muito.. }\end{array}$ \\
\hline
\end{tabular}




\begin{tabular}{|c|c|c|}
\hline \multicolumn{3}{|c|}{ DISCURSO 5 - CATEGORIAS, TEMAS E EXPRESSÕES CHAVE } \\
\hline CATEGORIA & TEMAS E SUB-TEMAS & EXPRESSÓES CHAVE \\
\hline \multirow[t]{3}{*}{$\begin{array}{l}\text { 1. CARACTERISTICAS } \\
\text { DE UMA BOA ESCOLA }\end{array}$} & $\begin{array}{l}\text { 1.1.4. Funcionamento efetivo das instâncias de } \\
\text { democratização da escola (Conselho de Escola. } \\
\text { Conselho de Classe, Associação de Pais e } \\
\text { Mestres e Grêmio Estudantil) }\end{array}$ & $\begin{array}{l}\text { Nossos Conselhos de Classe feitos com os pais dos } \\
\text { nossos alunos. As reuniões de pais e mães não sã } \\
\text { apenas para passar as notas dos filhos ou falar mal } \\
\text { deles, mas para fazer um trabalho conjunto de } \\
\text { verificar os problemas dos alunos e para resolver } \\
\text { conjuntamente estes problemas }\end{array}$ \\
\hline & $\begin{array}{l}\text { 1.1.5. Interesse e compromisso da equipe em } \\
\text { realizar um bom trabalho }\end{array}$ & $\begin{array}{l}\text { Acho que a equipe é muito interessada ...sempre tem } \\
\text { exceções, mas os professores que não querem nada } \\
\text { com nada acabam saindo da escola porque o grupo } \\
\text { pressiona para que todos trabalhem bem. }\end{array}$ \\
\hline & $\begin{array}{l}\text { 1.2. Qualidade de ensino } \\
\text { 1.2.1. Seriedade e profissionalismo da equipe } \\
\text { escolar }\end{array}$ & $\begin{array}{l}\text { A equipe daqui é séria. Tem gente que acha que a } \\
\text { gente exagera. Sempre tem quem é diferente, mas } \\
\text { todos agem com muito profissionalismo. Eles sabem } \\
\text { fazer o que fazem, gostam do que fazem e quem não } \\
\text { gosta e quer enrolar dá um jeito de ir para outra escola } \\
\text { mais folgada Tem alunos nossos que vão embora para } \\
\text { o Maria Alice, perto daqui. Uma aluna foi embora e } \\
\text { estava de volta, no outro dia. Eu disse, Viviane, jáa } \\
\text { voltou? Ela disse: “ Professora, naquela escola o que } \\
\text { menos tem é aula e nem o banheiro tem porta. Não dá } \\
\text { para ficar lá". E aqui não - temos aula, mesmo com } \\
\text { falta, o trinco quebrou, amanhã já se repõe o trinco; } \\
\text { queimou uma lâmpada, ela é trocada ...assim com a } \\
\text { carteira, com a lousa. Eu voto numa escola de } \\
\text { Carapicuiba, aqui do centro. Você entra e encontra } \\
\text { carteira feia, rabiscada, os alunos põem recado para os } \\
\text { outros na parede. Então eu só posso considerar que } \\
\text { esta é muito mais escola, no sentido de que as pessoas } \\
\text { agem como verdadeiros profissionais. }\end{array}$ \\
\hline
\end{tabular}




\begin{tabular}{|c|c|c|}
\hline \multicolumn{3}{|c|}{ DISCURSO 5 - CATEGORIAS, TEMAS E EXPRESSÕES CHAVE } \\
\hline CATEGORIA & TEMAS E SUB-TEMAS & EXPRESSÕES CHAVE \\
\hline \multirow[t]{2}{*}{$\begin{array}{l}\text { 1. CARACTERISTICAS } \\
\text { DE UMA BOA ESCOLA }\end{array}$} & $\begin{array}{l}\text { 1.2.2. Bons resultados de rendimento e } \\
\text { desempenho escolar }\end{array}$ & $\begin{array}{l}\text { Os meus filhos estudaram aqui e aprenderam a } \\
\text { pesquisar, a investigar, a questionar, a } \\
\text { participar...enfim, não tenho nada a reclamar da } \\
\text { maneira como eles foram formados aqui }\end{array}$ \\
\hline & 1.2.3. Otimização do tempo pedagógico & $\begin{array}{l}\text { Esta escola é boa porque valoriza o tempo que o aluno } \\
\text { fica na escola ...esta escola é taxada assim- todo } \\
\text { mundo teve férias e nós tivemos recuperação. Tinha } \\
\text { greve e a gente repunha aula minuto a minuto. A } \\
\text { direção entrava na classe e não tinha } 70 \% \text { dos alunos } \\
\text { - era outro dia de reposição. Nisso, esta escola sempre } \\
\text { foi linha dura. Aqui não se junta aula - e isto acontece } \\
\text { muito por ai. No noturno, é a mesma seriedade - não } \\
\text { tem esta coisa de não ter aula, do aluno voltar cedo } \\
\text { para casa ...os professores eventuais fazem um bom } \\
\text { trabalho e acho que isto mostra que não estamos } \\
\text { brincando aqui. Aconselhei amigas minhas a tirarem } \\
\text { os filhos de escola particular que é boa e trazer para cá } \\
\text { que é melhor. Nós temos preocupação com o aluno } \\
\text { que cabula, pois queremos o aluno dentro da sala de } \\
\text { aula. }\end{array}$ \\
\hline
\end{tabular}




\begin{tabular}{|c|c|c|}
\hline \multicolumn{3}{|c|}{ DISCURSO 5 - CATEGORIAS, TEMAS E EXPRESSÕES CHAVE } \\
\hline CATEGORIA & TEMAS E SUB-TEMAS & EXPRESSÕES CHAVE \\
\hline \multirow[t]{3}{*}{$\begin{array}{l}\text { 1. CARACTERISTICAS } \\
\text { DE UMA BOA ESCOLA }\end{array}$} & $\begin{array}{l}\text { 1.2.4. diversificação das atividades de ensino e } \\
\text { aprendizagem e utilização de recursos didático- } \\
\text { pedagógicos }\end{array}$ & $\begin{array}{l}\text { Esta escola é diferente em outro aspecto - ela é } \\
\text { preocupada com o aluno, a aula, o conteúdo, número } \\
\text { de aulas dadas durante o ano. Fazemos de tudo para } \\
\text { que as nossas aulas sejam interessantes ...usamos } \\
\text { video, TV, fazemos atividades culturais fora da } \\
\text { escola. Queremos com isso que o nosso aluno se sinta } \\
\text { bem na escola. A nossa biblioteca é muito boa.. uma } \\
\text { professora aposentada toma conta ... assim, os nossos } \\
\text { alunos têm mais oportunidade de voltar à escola pra } \\
\text { consultas, de gostar mais da escola. }\end{array}$ \\
\hline & $\begin{array}{l}\text { 1.2.5. Foco do trabalho pedagógico é a } \\
\text { permanência do aluno na escola e sua } \\
\text { aprendizagem efetiva }\end{array}$ & $\begin{array}{l}\text { Eu considero que esta é uma boa escola, } \\
\text { principalmente porque aqui há uma preocupação com } \\
\text { o aluno ..que o aluno esteja bem, que o aluno aprenda, } \\
\text { que o aluno não abandone a escola. Por exemplo, se } \\
\text { ele tiver um problema em sala de aula, nós chamamos } \\
\text { o pai, a mãe nós queremos saber porque. } \\
\text { Encaminhamos o aluno para o psicólogo, } \\
\text { aconselhamos os pais ... discutimos qual seria o } \\
\text { caminho a tomar para que o aluno não abandone a } \\
\text { escola. Acho que eu falo muito do trabalho com o } \\
\text { aluno porque esta é a minha função - me esforçar para } \\
\text { que os professores possam fazer um bom trabalho na } \\
\text { sala de aula, para que tudo o que decidimos fazer no } \\
\text { início do ano seja feito ...aulas, conteúdos, valores.. }\end{array}$ \\
\hline & $\begin{array}{l}\text { 1.2.6. A familia dos professores e funcionários } \\
\text { confia na qualidade do trabalho da escola } \\
\text { (filhos, sobrinhos e netos estudam na escola) }\end{array}$ & $\begin{array}{l}\text { A escola é mesmo boa porque se não fosse, os nossos } \\
\text { filhos não estudariam aqui. É raro uma classe em que } \\
\text { o professor não dá aula para um parente seu ...você } \\
\text { quer melhor atestado de que a escola é boa do que } \\
\text { este? Meus filhos estudaram aqui, as filhas da diretora } \\
\text { também. Que mais você quer? }\end{array}$ \\
\hline
\end{tabular}




\begin{tabular}{|c|c|c|}
\hline \multicolumn{3}{|c|}{ DISCURSO 5 - CATEGORIAS, TEMAS E EXPRESSÕES CHAVE } \\
\hline CATEGORIA & TEMAS E SUB-TEMAS & EXPRESSṌES CHAVE \\
\hline \multirow[t]{2}{*}{$\begin{array}{l}\text { 2. CARACTERISTICAS } \\
\text { DE UMA ESCOLA } \\
\text { SAUDÁVEL }\end{array}$} & $\begin{array}{l}\text { 2.1. Ambiente fisico de boa qualidade } \\
\text { (escola conservada, limpa, arborizada) }\end{array}$ & $\begin{array}{l}\text { Acho que você já pode ver que a escola é impecável ... } \\
\text { está inteira,. É arborizada, muito limpa, muito } \\
\text { conservada. Nós cuidamos para que os alunos não } \\
\text { sofram nenhum acidente aqui, cuidamos das } \\
\text { passarelas. Acho que é a escola em que a maioria das } \\
\text { pessoas gostariam de estudar. }\end{array}$ \\
\hline & $\begin{array}{l}\text { 2.2. Ambientes e/ou espaços da escola } \\
\text { particularmente saudáveis } \\
\text { 2.2.1. pátio escolar } \\
\text { 2.2.2. refeitório } \\
\text { 2.2.3. biblioteca }\end{array}$ & $\begin{array}{l}\text { O pátio é limpo, arejado ..tem verde de um lado e do } \\
\text { outro. Há bebedouros muito higiênicos e nós } \\
\text { mandamos examinar a qualidade da água que eles } \\
\text { bebem. } \\
\text { Nós temos orgulho do refeitório daqui ..é limpo, } \\
\text { arejado, clarinho ...acomoda umas } 300 \text { crianças ou } \\
\text { mais. A merenda é muito limpa - a diretora até } \\
\text { gostaria que ela fosse mais diversificada. Mas até os } \\
\text { professores comem merenda aqui } \\
\text { A biblioteca é bem equipada, tem muitos livros, tem } \\
\text { quem tome conta. Fica sempre aberta e atende aos } \\
\text { alunos que vêm muito para cá, fora de seu período de } \\
\text { aula ...daí, eles tomam merenda e são bem recebidos, } \\
\text { mesmo que não seja seu período }\end{array}$ \\
\hline
\end{tabular}




\begin{tabular}{|c|c|c|}
\hline \multicolumn{3}{|c|}{ DISCURSO 5 - CATEGORIAS, TEMAS E EXPRESSÕES CHAVE } \\
\hline CATEGORIA & \begin{tabular}{|c|} 
TEMAS E SUB-TEMAS \\
\end{tabular} & EXPRESSÕES CHAVE \\
\hline \multirow[t]{2}{*}{$\begin{array}{l}\text { 2. CARACTERÍSTICAS } \\
\text { DE UMA ESCOLA } \\
\text { SAUDÁVEL }\end{array}$} & 2.2.4. banheiros & $\begin{array}{l}\text { Os nossos banheiros são limpos, tanto o dos } \\
\text { professores como o dos alunos. A comunidade sempre } \\
\text { mantêm papel higiênico no banheiro ...lá tem } \\
\text { espelhos, para eles poderem se olhar, verificar como } \\
\text { estão .... Todos os alunos precisam pedir permissão } \\
\text { para ir ao banheiro, até os do colegial. Há sempre } \\
\text { alguém que estranha isto, mas é um hábito bom da } \\
\text { escola e, aos poucos, todos se acostumam. Se um } \\
\text { aluno tem algum problema e precisa de usar muito o } \\
\text { banheiro, eu aviso o professor. Um banheiro teve uma } \\
\text { porta estragada - os alunos consertaram }\end{array}$ \\
\hline & $\begin{array}{l}\text { 2.3. Gestão escolar } \\
\text { 2.3.1. Clima amigável e boa nivel de organização } \\
\text { 2.3.2. Preocupação com a qualidade de vida das } \\
\text { pessoas que vivem na escola }\end{array}$ & $\begin{array}{l}\text { O clima da escola é muito bom. Todos têm acesso à } \\
\text { direção, ela conhece os pais e alunos pelo nome. Os } \\
\text { alunos gostam daqui ..eles não fogem ...vez ou outra } \\
\text { um dá uma escapada, mas nós ficamos no pé. O aluno } \\
\text { tem liberdade de conversar com a direção, com a } \\
\text { coordenação. Eles fazem as suas reivindicações. A } \\
\text { escola é muito organizada e se não fosse assim, não } \\
\text { sei como poderia ser uma escola saudável. } \\
\text { Esta escola preocupa-se muito também com a vida } \\
\text { funcional do professor. A nossa vida é rigorosamente } \\
\text { em dia - adicional, tudo em dia, Eu acho que isso } \\
\text { deixa o professor satisfeito, é uma das coisas que } \\
\text { segura o professor aqui. Também é uma forma de } \\
\text { contribuir para que a vida deles seja melhor, pois o } \\
\text { salário vai ser melhor e nem terão problema na } \\
\text { aposentadoria. }\end{array}$ \\
\hline
\end{tabular}




\begin{tabular}{|c|c|c|}
\hline \multicolumn{3}{|c|}{ DISCURSO 5 - CATEGORIAS, TEMAS E EXPRESSÕES CHAVE } \\
\hline CATEGORIA & TEMAS E SUB-TEMAS & EXPRESSŌES CHAVE \\
\hline $\begin{array}{l}\text { 2. CARACTERÍSTICAS } \\
\text { DE UMA ESCOLA } \\
\text { SAUDÁVEL }\end{array}$ & $\begin{array}{l}\text { 2.3.3. Responsabilização dos alunos e } \\
\text { comunidade pela conservação da escola }\end{array}$ & $\begin{array}{l}\text { Nossos alunos sabem que têm que conservar a escola, } \\
\text { pois ela é de todos e vai ser um dia dos filhos deles. } \\
\text { Um dia, dois alunos quebraram alguns vasos - nós } \\
\text { não brigamos - chamamos a familia, explicamos que } \\
\text { aquilo era patrimônio nosso - e eles acertaram tudo. } \\
\text { Um aluno riscou a mesa do professor - fizemos a } \\
\text { mesma coisa. A mesa ficou mais limpa que antes. É } \\
\text { um trabalho incansável. Sujou, tem que limpar na } \\
\text { hora. Tem que conscientizar que a escola é nossa e } \\
\text { nós temos que zelar por ela }\end{array}$ \\
\hline & 2.4. Qualidade do ensino & \\
\hline
\end{tabular}




\begin{tabular}{|c|c|c|}
\hline \multicolumn{3}{|c|}{ DISCURSO 5 - CATEGORIAS, TEMAS E EXPRESSÕES CHAVE } \\
\hline CATEGORIA & TEMAS E SUB-TEMAS & EXPRESSÕ̃ES CHAVE \\
\hline \multirow[t]{2}{*}{$\begin{array}{l}\text { 2. CARACTERISTICAS } \\
\text { DE UMA ESCOLA } \\
\text { SAUDÁVEL }\end{array}$} & $\begin{array}{l}\text { 2.4.1. diversificação das situações de ensino e } \\
\text { aprendizagem e utilização de recursos didático- } \\
\text { pedagógicos }\end{array}$ & $\begin{array}{l}\text { Nós saimos sempre com os alunos - todos os anos } \\
\text { vamos com eles à Bolsa de Valores. Eu mesma fiquei } \\
\text { encantada a primeira vez que fui e tenho a certeza de } \\
\text { que muita gente boa nunca visitou a Bolsa. O trabalho } \\
\text { de nossos alunos foi muito elogiado lá. Vamos à Coca } \\
\text { Cola e dá para discutir muito sobre a produção, } \\
\text { capitalismo - a linha de montagem, a origem da } \\
\text { matéria prima ...dá até para ver como somos } \\
\text { explorados - o xarope da Coca Cola vem da } \\
\text { Amazônia, porque lá tem canela. Vamos ao Museu de } \\
\text { Arqueologia, da USP, ao Museu do Crime ...enfim, } \\
\text { saímos para atividades culturais. Sempre fomos a } \\
\text { Paranapiacaba ...paramos pois ficamos com medo da } \\
\text { segurança das pessoas. A escola tira fotos e essas } \\
\text { fotos são mostradas para todos ..eles têm orgulho } \\
\text { disto. Vamos a Teatro, a atividades culturais ...a } \\
\text { escola é um polo cultural também. Eles já foram para } \\
\text { o programa da Eliana, já participaram do projeto das } \\
\text { Futuras Gerações. A comunidade fica orgulhosa de } \\
\text { ver o trabalho dos filhos.. Eu considero isto muito } \\
\text { bom e muito saudável }\end{array}$ \\
\hline & $\begin{array}{l}\text { 2.5. Relação de reciprocidade entre uma escola } \\
\text { saudável e uma escola de boa qualidade } \\
\text { 2.5.1. Nem sempre uma boa escola é uma escola } \\
\text { saudável }\end{array}$ & $\begin{array}{l}\text { O Fornasaro é uma escola boa e é saudável...mas } \\
\text { imagino que nem sempre isto acontece. Tem escola } \\
\text { que é boa no sentido tradicional - tem fama, faz o } \\
\text { aluno entrar no vestibular - mas não promove a saúde } \\
\text { dos alunos e nem é agradável por dentro, nem é } \\
\text { saudável, como estamos dizendo. }\end{array}$ \\
\hline
\end{tabular}




\begin{tabular}{|c|c|c|}
\hline \multicolumn{3}{|c|}{ DISCURSO 5 - CATEGORIAS, TEMAS E EXPRESSÕES CHAVE } \\
\hline CATEGORIA & TEMAS E SUB-TEMAS & EXPRESSÓ́ES CHAVE \\
\hline \multirow[t]{2}{*}{$\begin{array}{l}\text { 3. PAPEL DA ESCOLA } \\
\text { NA ÁREA DA SAÚDE }\end{array}$} & $\begin{array}{l}\text { 3.1. promoção da saúde pela articulação da teoria } \\
\text { com a prática }\end{array}$ & $\begin{array}{l}\text { O papel nosso é importante porque temos que } \\
\text { promover a saúde dos alunos. No ano passado, } \\
\text { fizemos um projeto de obesidade da criança, pois } \\
\text { começamos a ter este problema. No refeitório, as } \\
\text { crianças aprendem a comer, a ter hábitos saudáveis, a } \\
\text { não comer exagerado. Precisamos também garantir o } \\
\text { conteúdo da saúde ... fazer sempre a teoria casada com } \\
\text { a prática. Tenho confirmado que a escola tem muita } \\
\text { influência sobre a saúde ...se aqui o ambiente é } \\
\text { saudável, estamos oferecendo um exemplo para as } \\
\text { crianças. Temos que cultivar hábitos de higiene - } \\
\text { temos trabalho com o piolho, toda } 4^{\circ} \text { feira nós } \\
\text { aplicamos flúor nas crianças. }\end{array}$ \\
\hline & $\begin{array}{l}\text { 3.2. encaminhamento dos alunos aos serviços de } \\
\text { saúde }\end{array}$ & $\begin{array}{l}\text { Temos que encaminhar também os alunos que } \\
\text { precisam de atendimento ... encaminhamos para o } \\
\text { postinho, batalho para que os nossos alunos sejam } \\
\text { atendidos e bem atendidos. Telefono para o pessoal da } \\
\text { saúde, converso com as mães, com as } \\
\text { crianças...verifico se foram bem atendidas. Era mais } \\
\text { fácil quando a gente tinha dois dentistas da prefeitura } \\
\text { aqui, mas não podemos ficar lamentando. }\end{array}$ \\
\hline
\end{tabular}




\begin{tabular}{|c|c|c|}
\hline \multicolumn{3}{|c|}{ DISCURSO 5 - CATEGORIAS, TEMAS E EXPRESSÕES CHAVE } \\
\hline CATEGORIA & TEMAS E SUB-TEMAS & EXPRESSÕES CHAVE \\
\hline $\begin{array}{l}\text { 4. PROCESSO DE } \\
\text { CONSTRUÇÃO DE UMA } \\
\text { ESCOLA SAUDÁVEL }\end{array}$ & $\begin{array}{l}\text { 4.1. Tempo de construção de uma escola } \\
\text { saudável } \\
\text { 4.1.1. Não há como estipular um prazo, pois se } \\
\text { trata de uma tarefa contínua }\end{array}$ & $\begin{array}{l}\text { Eu considero que a nossa escola é uma escola } \\
\text { saudável e foi um processo lento, uma construção no } \\
\text { decorrer dos anos. Aos poucos você vai incorporando } \\
\text { as coisas boas, tirando aquilo que é ruim. Se bem que } \\
\text { eu reconheço que as coisas vão mudando muito } \\
\text { rapidamente. Num dia em que há uma rebelião numa } \\
\text { delegacia de policia, o helicóptero está lá mostrando. } \\
\text { Acontece aqui e já está passando na rede Globo, na } \\
\text { Europa ...é uma coisa simultânea, Mas na escola a } \\
\text { coisa tem que ser mais lenta e você pode até me achar } \\
\text { conservadora. Eu acho que tem que parar, tem que } \\
\text { pensar, analisar: o que não está bom, volta para trás }\end{array}$ \\
\hline & $\begin{array}{l}\text { 4.2. Condições essenciais para a construção de } \\
\text { uma escola saudável } \\
\text { 4.2.1. Vontade de querer fazer } \\
\begin{array}{l}\text { 4.2.2. Processo compartilhado entre todos, } \\
\text { inclusive com a comunidade }\end{array}\end{array}$ & $\begin{array}{l}\text { A equipe precisa querer fazer ...precisa ter coragem de } \\
\text { se responsabilizar pela melhoria da qualidade da } \\
\text { escola...precisa arregaçar as mangas e fazer. } \\
\text { Precisa ser um trabalho de todos - de dentro e de fora } \\
\text { da escola. Hoje mesmo, nas horas de trabalho } \\
\text { pedagógico, nós discutimos uma postura conjunta do } \\
\text { corpo docente - dissemos que quem destoar, o grupo } \\
\text { vai cobrar. Temos que estabelecer o diálogo como } \\
\text { regra ....conversar sempre, tornar a escola agradável. }\end{array}$ \\
\hline
\end{tabular}




\begin{tabular}{|c|c|c|}
\hline \multicolumn{3}{|c|}{ DISCURSO 5 - CATEGORIAS, TEMAS E EXPRESSÕES CHAVE } \\
\hline CATEGORIA & TEMAS E SUB-TEMAS & EXPRESSÕES CHAVE \\
\hline \multirow{7}{*}{$\begin{array}{l}\text { 4. PROCESSO DE } \\
\text { CONSTRUÇÃO DE UMA } \\
\text { ESCOLA SAUDÁVEL }\end{array}$} & 4.2.3. Estimulação e cobrança constantes & Precisa de estímulo e de cobrança. $O$ que você \\
\hline & & $\begin{array}{l}\text { percebe que num ano falhou, no outro voce procura } \\
\text { consertar. O que você viu que era bom, aumenta }\end{array}$ \\
\hline & & $\begin{array}{l}\text { aquilo. Aquilo que você viu que era preciso ser feito, } \\
\text { você chama alguém, pede ajuda. Se não for desse } \\
\text { jeito, vendo cada passo, não dá }\end{array}$ \\
\hline & $\begin{array}{l}\text { 4.2.4. Profissionais precisam acreditar no novo, } \\
\text { em si mesmos, na comunidade e na equipe e criar } \\
\text { um clima de amizade }\end{array}$ & $\begin{array}{l}\text { Acho que as pessoas têm um pouco de medo do novo } \\
\text {...eu tenho, pelo menos. Para a escola ser cada vez } \\
\text { melhor e mais saudável, ela precisa perder este medo }\end{array}$ \\
\hline & 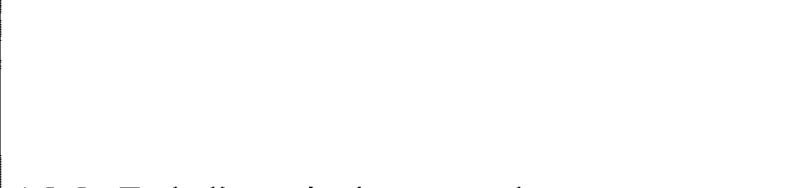 & $\begin{array}{l}\text {...se cada um souber que o outro também tem medo, } \\
\text { acho que já é um passo para a frente. O novo tem que } \\
\text { ser melhor do que o velho ...não é qualquer novo...a } \\
\text { educação está cheia de modismos. }\end{array}$ \\
\hline & 4.25. Trabalho voltado para o aluno & $\begin{array}{l}\text { Para que a escola seja boa e saudável, a nossa } \\
\text { preocupação tem que ser com o aluno. Nós temos que } \\
\text { ter sempre isto presente, senão a gente se perde. } \\
\text { Limpa a escola, compra materiais interessantes, faz } \\
\text { passeios, mas nada que represente alguma coisa para o } \\
\text { aluno. Se a escola muda e nada muda para melhor na } \\
\text { sala de aula, acho que não adianta. Se o aluno se sente } \\
\text { bem na escola, se a escola é limpa e bonita, se o } \\
\text { professor dá uma aula boa, a escola será saudável. }\end{array}$ \\
\hline & 4.3. Contribuição pessoal & \\
\hline
\end{tabular}




\begin{tabular}{|c|c|c|}
\hline \multicolumn{3}{|c|}{ DISCURSO 5 - CATEGORIAS, TEMAS E EXPRESSÕES CHAVE } \\
\hline CATEGORIA & TEMAS E SUB-TEMAS & EXPRESSÕES CHAVE \\
\hline $\begin{array}{l}\text { 4. PROCESSO DE } \\
\text { CONSTRUÇÃO DE UMA } \\
\text { ESCOLA SAUDÁVEL }\end{array}$ & $\begin{array}{l}\text { 4.4.1. Estabelecimento de canais de comunicação } \\
\text { entre os professores e a família dos alunos, para } \\
\text { assegurar a escolaridade básica ao aluno }\end{array}$ & $\begin{array}{l}\text { Acho que tenho colaborado para melhorar a relação da } \\
\text { escola e dos professores com os alunos e suas } \\
\text { familias. Eu aprendi a conviver com os alunos e seus } \\
\text { problemas e tenho procurado, sempre que possivel, } \\
\text { colocar a familia em contato com a escola e a escola } \\
\text { também em contato com a casa do aluno. Ligo para } \\
\text { mãe no serviço e me coloco à disposição dela a } \\
\text { qualquer hora. Controlo o aluno que estava cabulando } \\
\text { - vou à quadra, pergunto ao professo. Se a mãe não } \\
\text { pode vir à reunião - e essas reuniões são muito } \\
\text { importantes, pois se discute nelas o trabalho da escola- } \\
\text { eu me disponho a atendê-la em qualquer horário, á } \\
\text { tarde, á noite. E tem dado certo. Olha, no final do ano } \\
\text { a gente está um caco fazendo tudo isto - é } \\
\text { desgastante. E chama pai, chama mãe, atende por } \\
\text { telefone, É professor que me entrega bilhete para eu } \\
\text { entregar ao pai. E tem que pegar bilhete de mãe para } \\
\text { entregar para professora, Mas eu deixo bem claro...o } \\
\text { professor acha que a partir do momento em que o } \\
\text { aluno deu problema, ele tem que ir correndo atrás do } \\
\text { conselho tutelar. Mas eu acho que o caminho para } \\
\text { você fazer frente a essa violência que está ai é chamar } \\
\text { a familia para a responsabilidade do papel dela e } \\
\text { aconselhar o aluno. Eu acho que o aconselhamento dá } \\
\text { certo. Tem um aluno aqui que se chama William, esse } \\
\text { aluno nós ganhamos. Tem um que se chama Maurício } \\
\text { que se a escola tivesse fechado a porta para ele, a rua } \\
\text { tinha abraçado ele. Eu falo isto para os pais. Eu falo } \\
\text { que se a escola puser os alunos para fora da escola, a } \\
\text { rua abraça. E quando a rua devolver este aluno para os } \\
\text { pais, ele já estará marcado, com seqüelas. Então nós } \\
\text { temos que abraçar aqui, na escola. Não podemos } \\
\text { soltar. A escola tem que ser interessante, o aluno tem } \\
\text { que ser ouvido, tem que poder contar as suas } \\
\text { experiências...Agora, se a gente atraçar e o pai solta, a } \\
\text { rua abraça. }\end{array}$ \\
\hline
\end{tabular}




\begin{tabular}{|c|c|c|}
\hline \multicolumn{3}{|c|}{ DISCURSO 5 - CATEGORIAS, TEMAS E EXPRESSÕES CHAVE } \\
\hline CATEGORIA & TEMAS E SUB-TEMAS & EXPRESSÕES CHAVE \\
\hline $\begin{array}{l}\text { 4. PROCESSO DE } \\
\text { CONSTRUÇÃO DE UMA } \\
\text { ESCOLA SAUDÄVEL }\end{array}$ & $\begin{array}{l}\text { 4.4.2. Aperfeiçoamento das relações entre } \\
\text { professores e coordenação pedagógica } \\
\text { (estabelecimento de clima de honestidade e } \\
\text { franqueza) }\end{array}$ & $\begin{array}{l}\text { Em primeiro lugar, eu sou honesta com as pessoas. } \\
\text { Com os professores, procuro sempre deixar as coisas } \\
\text { muito claras - não guardo mágoa, mesmo quando } \\
\text { tenho algum desentendimento. Por exemplo, nos } \\
\text { saimos em excursão e eu dividi a turma de um } \\
\text { professor - metade foi num ônibus, a outra metade, no } \\
\text { outro ônibus. Nem percebi que dividi a turma, mas } \\
\text { tinha gente que cuidava dos alunos dos dois ônibus e } \\
\text { estava tudo sob controle. A professora ficou muito } \\
\text { brava. Reclamou muito - eu não liguei e não fiquei } \\
\text { com raiva. Noutro dia, conversamos normal e ela } \\
\text { pediu desculpas. }\end{array}$ \\
\hline
\end{tabular}




\begin{tabular}{|c|c|c|}
\hline \multicolumn{3}{|c|}{ DISCURSO 5 - CATEGORIAS, TEMAS E EXPRESSŌES CHAVE } \\
\hline CATEGORIA & TEMAS E SUB-TEMAS & EXPRESSÕES CHAVE \\
\hline $\begin{array}{l}\text { 4. PROCESSO DE } \\
\text { CONSTRUÇÃO DE UMA } \\
\text { ESCOLA SAUDÁVEL }\end{array}$ & $\begin{array}{l}\text { 4.5. Receio quanto à descontinuidade do projeto } \\
\text { da escola }\end{array}$ & $\begin{array}{l}\text { eu não sei como vai ficar aqui para a frente. A familia } \\
\text { está se distanciando muito dos filhos. Com o } \\
\text { desemprego, as mães empregam no que der .... } \\
\text { diarista, qualquer horário. Ficam mais distantes da } \\
\text { responsabilidade de zelar, conosco, pelos filhos. } \\
\text { Confesso que tenho receio de que os pais não } \\
\text { continuem no mesmo ritmo de sempre. No ano } \\
\text { passado, um aluno cabulava aula todos os dias. Liguei } \\
\text { para a mãe, várias vezes. Ela ficou irritada e disse que } \\
\text { era papel da escola resolver disso. Se a familia perder } \\
\text { este referencial - não se sentir responsável - vai ser } \\
\text { mais dificil. Tem pais que querem saber que os filhos } \\
\text { estão aqui dentro e mais nada. E assim não anda. Na } \\
\text { recuperação de janeiro, achei que as mães ficaram } \\
\text { pensando que os filhos poderão folgar durante o ano } \\
\text { todo, pois terão recuperação nas férias. Tenho receio } \\
\text { de que a violência aumente...num final de semana, } \\
\text { fizemos uma atividade - entrou uma gangue e veio um } \\
\text { garoto de fora armado aqui, para falar com uma aluna. } \\
\text { Um professor enfrentou a gangue ...tenho medo que as } \\
\text { coisas possam mudar. Temos que pensar muito porque } \\
\text { a violência é alguma coisa que mina o trabalho da } \\
\text { escola. }\end{array}$ \\
\hline
\end{tabular}




\begin{tabular}{|c|c|c|}
\hline \multicolumn{3}{|c|}{ DISCURSO 6 - CATEGORIAS, TEMAS E EXPRESSÕES CHAVE } \\
\hline CATEGORIA & TEMAS E SUB-TEMAS & EXPRESSŌES CHAVE \\
\hline \multirow[t]{3}{*}{$\begin{array}{l}\text { 1. CARACTERISTICAS } \\
\text { DE UMA BOA ESCOLA }\end{array}$} & $\begin{array}{l}\text { 1.1. Estrutura e ambiente fisico de boa qualidade } \\
\text { (escola limpa, boas instalações) }\end{array}$ & $\begin{array}{l}\text { É uma escola muito boa e isto é reconhecido em } \\
\text { Carapicuiba. É uma escola limpa, com uma boa } \\
\text { estrutura fisica e ótimas instalações. }\end{array}$ \\
\hline & $\begin{array}{l}\text { 1.2. Gestão escolar } \\
\text { 1.2.1. Presença fisica da direção na escola e } \\
\text { reconhecida competência administrativa } \\
\text { 1.2.2. Entrosamento entre os elementos da equipe }\end{array}$ & $\begin{array}{l}\text { Quando tive que sair da minha antiga escola, resolvi ir } \\
\text { para uma escola boa. Como o Fornasaro era uma } \\
\text { escola que todos reconheciam ser uma boa escola, } \\
\text { resolvi escolher o Fornasaro, caso tivesse } \\
\text { oportunidade. E tive - quando cheguei no Fornasaro, } \\
\text { não me decepcionei - eu achei que tudo o que as } \\
\text { pessoas falavam era verdade. Eu estudei em } \\
\text { Carapicuiba e achei que esta era uma escola melhor } \\
\text { inclusive das que eu tinha estudado. Esta é uma escola } \\
\text { que tem direção e isto em dois sentidos: a diretora } \\
\text { vive aqui e sabe qual é o seu papel - faz este papel } \\
\text { muito bem. } \\
\text { Os professores aqui estão bem entrosados...às vezes, } \\
\text { tem um problema de panela e os professores mais } \\
\text { antigos torcem o nariz para os que acabam de chegar. } \\
\text { Acho que o ingresso dos professores que passaram no } \\
\text { último concurso vai resolver isto. Quando a panela } \\
\text { não trabalha, o entrosamento contribui para que a } \\
\text { escola melhore o seu trabalho. }\end{array}$ \\
\hline & 1.3.Qualidade de ensino & \\
\hline
\end{tabular}




\begin{tabular}{|c|c|c|}
\hline \multicolumn{3}{|c|}{ DISCURSO 6 - CATEGORIAS, TEMAS E EXPRESSÓES CHAVE } \\
\hline CATEGORIA & TEMAS E SUB-TEMAS & EXPRESSÓES CHAVE \\
\hline $\begin{array}{l}\text { 1. CARACTERÍSTICAS } \\
\text { DE UMA BOA ESCOLA }\end{array}$ & $\begin{array}{l}\text { 1.3.1. diversificação das atividades de ensino } \\
\text { aprendizagem e utilização de recursos didático- } \\
\text { pedagógicos }\end{array}$ & $\begin{array}{l}\text { A escola conta com uma excelente biblioteca e uma } \\
\text { ampla sala de video ...TV de } 29 \text { polegadas, muitos } \\
\text { vídeos. A escola usa muito este material que não é } \\
\text { toda escola particular que tem. Uma outra coisa } \\
\text { importante, são as atividades que os professores } \\
\text { realizam .. um festival de música que a professora de } \\
\text { Inglês organizou - ela selecionou um grupo de cada } \\
\text { classe e dai os alunos ensaiaram as suas músicas. No } \\
\text { dia em que ela foi fazer este festival, ela precisava da } \\
\text { sala ao lado, para reunir todo mundo. Eu estava dando } \\
\text { aula na } 8 \text { série e fui com eles ao salão. Vi aluno que } \\
\text { eu achava que era mudo que de repente chegou lá no } \\
\text { palco e soltou a franga . Dai eu percebi como é } \\
\text { importante para os alunos fazer alguma coisa a mais } \\
\text { do que pesquisar, estudar, responder perguntas ..eles } \\
\text { se comportavam diferente numa situação mais } \\
\text { descontraida. Outra vez, a professora de Educą̧ão } \\
\text { Física organizou um Festival de Dança na escola - um } \\
\text { concurso. Os alunos vinham mais felizes para escola } \\
\text {... ensaiavam, dançavam.. Nos dois dias que durou o } \\
\text { Concurso, eles nem precisaram ser fiscalizados. Todas } \\
\text { estas coisas enriquecem os anos e fazem com que a } \\
\text { escola seja de boa qualidade e saudável. }\end{array}$ \\
\hline
\end{tabular}




\begin{tabular}{|c|c|c|}
\hline \multicolumn{3}{|c|}{ DISCURSO 6 - CATEGORIAS, TEMAS E EXPRESSÕES CHAVE } \\
\hline CATEGORIA & TEMAS E SUB-TEMAS & \begin{tabular}{|r|} 
EXPRESSÓES CHAVE \\
\end{tabular} \\
\hline \multirow[t]{3}{*}{$\begin{array}{l}\text { 2. CARACTERISTICAS } \\
\text { DE UMA ESCOLA } \\
\text { SAUDÄVEL }\end{array}$} & $\begin{array}{l}\text { 2.1. Ambiente fisico de boa qualidade } \\
\text { (escola limpa, bonita, organizada e bem } \\
\text { construida) }\end{array}$ & $\begin{array}{l}\text { Para comprovar que a escola é saudável basta dar uma } \\
\text { olhada em tudo. A escola é limpa, é bonita, é } \\
\text { organizada, todas as coisas estão no seu lugar. Não é } \\
\text { uma escola decadente, como muitas que a gente vê } \\
\text { por ai. Outra coisa boa é a geometria da escola. } \\
\text { Quando a diretora sai no corredor, tem uma visão } \\
\text { panorâmica de toda escola. Aqui não tem grades, nem } \\
\text { andares ...não há portões trancados, ninguém fica } \\
\text { isolado. }\end{array}$ \\
\hline & $\begin{array}{l}\text { 2.2. Gestão escolar } \\
\text { 2.2.1. Cumprimento adequado das funções } \\
\text { burocráticas e de gestão do curriculo } \\
\text { (presença efetiva dos profissionais) }\end{array}$ & $\begin{array}{l}\text { Nesta escola, as pessoas têm um cargo e exercem este } \\
\text { cargo. Nas outras escolas, o diretor não fica } 8 \text { horas na } \\
\text { escola - ele trabalha em dois lugares e aparece ou só } \\
\text { para abrir ou só para fechar a escola. O que mais } \\
\text { sobrecarrega a estrutura é a parte burocrática - o vice } \\
\text { diretor, quando falta o diretor, concentra-se na } \\
\text { burocracia. O coordenador faz papel de porteiro, de } \\
\text { secretário .... Aqui não. A diretora está presente o } \\
\text { tempo todo - é comprometida, sabe o caso de cada } \\
\text { aluno, conhece todos os professores - o vice diretor } \\
\text { apoia o diretor e o trabalho é bem distribuido e o } \\
\text { coordenador faz um trabalho pedagógico. }\end{array}$ \\
\hline & $\begin{array}{l}\text { 2.3. Ensino de boa qualidade } \\
\text { 2.3.1. Bons resultados de rendimento e } \\
\text { desempenho escolar }\end{array}$ & $\begin{array}{l}\text { De maneira geral, esta é uma escola que consegue } \\
\text { bons resultados com os alunos. Eles se saem bem } \\
\text { também lá fora, o que prova que nós estamos } \\
\text { trabalhando bem. É lógico que sempre se tem que } \\
\text { melhorar. }\end{array}$ \\
\hline
\end{tabular}




\begin{tabular}{|c|c|c|}
\hline \multicolumn{3}{|c|}{ DISCURSO 6 - CATEGORIAS, TEMAS E EXPRESSÕES CHAVE } \\
\hline CATEGORIA & TEMAS E SUB-TEMAS & EXPRESSŌES CHAVE \\
\hline \multirow[t]{3}{*}{$\begin{array}{l}\text { 3. PAPEL DA ESCOLA } \\
\text { NA ÁREA DA SAÚDE }\end{array}$} & $\begin{array}{l}\text { 3.1. promoção da saúde pela articulação da teoria } \\
\text { com a prática }\end{array}$ & $\begin{array}{l}\text { Eu vejo que o papel da escola é fundamental na parte } \\
\text { social, acho que na área da promoção da saúde. Acho } \\
\text { que não é só falar de teoria, falar sobre a saúde ou das } \\
\text { doenças. É necessário mais que isso - que o aluno } \\
\text { pratique as coisas, pelo menos as que são possiveis. }\end{array}$ \\
\hline & $\begin{array}{l}\text { 3.2. transmissão de conhecimentos e de } \\
\text { referências no campo da saúde }\end{array}$ & $\begin{array}{l}\text { Trabalho com sexualidade, com DSTs, com } \\
\text { contracepção, enfim com os assuntos que interessam } \\
\text { aos adolescentes. A minha disciplina me dá bastante } \\
\text { margem para entrar nas questões de saúde ...saúde } \\
\text { fisica, por exemplo, fora isso, fico meio delicado, pois } \\
\text { a Delegacia impede que a realização de atividades de } \\
\text { lazer fora d escola, que envolvam um único professor. } \\
\text { Ela faz a exigência de que exista um projeto, que } \\
\text { envolva conteúdos e vários professores. }\end{array}$ \\
\hline & $\begin{array}{l}\text { 3.3. Foco do trabalho pedagógico é a } \\
\text { permanência do aluno na escola e sua } \\
\text { aprendizagem efetiva }\end{array}$ & $\begin{array}{l}\text { O ponto que eu vejo positivo nesta escola é o } \\
\text { seguinte: se eu tenho um problema com um aluno e o } \\
\text { encaminho para a direção ou coordenação, nunca se } \\
\text { parte para afastar o aluno ...a escola procura conhecer } \\
\text { o problema do aluno, qual será o motivo do trauma do } \\
\text { aluno. Aqui .vale o ditado : bater não adianta - .tem } \\
\text { que recorrer ao diálogo. Nosso objetivo é trazer o } \\
\text { aluno para a aula, para dentro da sala de aula ...nunca } \\
\text { afastar. Neste sentido, a direção e a coordenação } \\
\text { pedagógica ajudam bastante. A gente chama os pais, } \\
\text { envolve todo mundo. Ano passado tivemos bons } \\
\text { resultados conversando muito só com os alunos. Com } \\
\text { a conversa, cada vez mais os alunos foram } \\
\text { melhorando. E isto é o mínimo que a escola precisa } \\
\text { fazer para que os alunos sejam cidadãos com saúde : } \\
\text { que saibam ler, escrever, conversar, argumentar...essas } \\
\text { coisas. }\end{array}$ \\
\hline
\end{tabular}




\begin{tabular}{|c|c|c|}
\hline \multicolumn{3}{|c|}{ DISCURSO 6 - CATEGORIAS, TEMAS E EXPRESSỐES CHAVE } \\
\hline CATEGORIA & \begin{tabular}{|l} 
TEMAS E SUB-TEMAS \\
\end{tabular} & \begin{tabular}{|l} 
EXPRESSÓES CHAVE \\
\end{tabular} \\
\hline $\begin{array}{l}\text { 3. PAPEL DA ESCOLA } \\
\text { NA ÁREA DA SAÚDE }\end{array}$ & $\begin{array}{l}\text { 3.4. Encaminhamento dos alunos aos serviços de } \\
\text { saúde }\end{array}$ & $\begin{array}{l}\text { Acho que a escola deveria contar com serviços de } \\
\text { saúde. Nós tínhamos dentistas e na atual situação, o } \\
\text { prefeito tirou os dentistas daqui. Mas temos que } \\
\text { continuar com os encaminhamentos necessários, para } \\
\text { o postinho da prefeitura. Também se determinado } \\
\text { aluno causa algum problema na sala de aula, seja } \\
\text { porque ele tem um problema mental ou sei lá o que, } \\
\text { precisa encaminhar. }\end{array}$ \\
\hline \multirow{3}{*}{$\begin{array}{l}\text { 4. CARACTERÍSTICAS } \\
\text { DO PROCESSO DE } \\
\text { CONSTRUÇÃO DE UMA } \\
\text { ESCOLA SAUDÁVEL }\end{array}$} & $\begin{array}{l}\text { 4.1. Tempo de construção de uma escola } \\
\text { saudável } \\
\text { 4.1.1. Tempo é previsivel, de aproximadamente } \\
\text { um ano. }\end{array}$ & $\begin{array}{l}\text { Pouquíssimo tempo. Em um ano acho que a direção } \\
\text { consegue mudar o astral da escola. }\end{array}$ \\
\hline & $\begin{array}{l}\text { 4.2. Condições essenciais para a construção de } \\
\text { uma escola saudável } \\
\text { 4.2.1. Processo compartilhado entre todos, } \\
\text { inclusive com a comunidade } \\
\text { 4.2.2. Estimulação E cobrança constantes } \\
\text { 4.3. Contribuicão pessoal }\end{array}$ & $\begin{array}{l}\text { Precisa ter alguém que alavanque. Ela tem que reunir } \\
\text { um grupo de força que tenha as mesmas idéias. A } \\
\text { partir dai, é questão de estabelecer combinações, } \\
\text { estabelecer as regras do novo jogo. Precisa de alguém } \\
\text { que alavanque, que consiga chamar pessoas para a } \\
\text { mesma idéia ..precisa de ter força de convencimento } \\
\text { Precisa ter alguém que dê o start e que cobre sempre. }\end{array}$ \\
\hline & & \\
\hline
\end{tabular}




\begin{tabular}{|c|c|c|}
\hline \multicolumn{3}{|c|}{ DISCURSO 6 - CATEGORIAS, TEMAS E EXPRESSÕ ES CHAVE } \\
\hline CATEGORIA & TEMAS E SUB-TEMAS & EXPRESSÕES CHAVE \\
\hline $\begin{array}{l}\text { 4. CARACTERISTICAS } \\
\text { DO PROCESSO DE } \\
\text { CONSTRUÇÃO DE UMA } \\
\text { ESCOLA SAUDÄVEL }\end{array}$ & 4.3.1. abordagem de temas de saúde nas aulas & $\begin{array}{l}\text { Como já falei, acho que a minha única contribuição é } \\
\text { trabalhar bem com os temas de saúde. Pode parecer } \\
\text { pouco, mas os alunos se interessa muito pelas } \\
\text { discussões sobre sexualidade, DSTs, AIDS, gravidez, } \\
\text { aborto...eles são adolescentes e estão vivendo esta } \\
\text { fase. Não se trata apenas de passar informações, mas } \\
\text { de dar um espaço para que eles possam discutir essas } \\
\text { coisas que nem todos podem conversar na casa. }\end{array}$ \\
\hline & $\begin{array}{l}\text { 4.4. Receio quanto à descontinuidade do projeto } \\
\text { da escola }\end{array}$ & $\begin{array}{l}\text { Tenho sempre medo das reformas da Secretaria. A } \\
\text { progressão continuada pode deixar as pessoas } \\
\text { displicentes, pois elas não entendem o espírito da } \\
\text { coisa ...só registram que o Estado quer aprovar todo } \\
\text { mundo e ficam desmotivados para fazer um trabalho } \\
\text { sério na escola.. Além disso, as novas diretrizes da } \\
\text { Diretoria dificultam que a gente ofereça atividades de } \\
\text { lazer e vou insistir neste assunto. A antiga direção } \\
\text { proibia a ida ao Play Center. Fomos no ano passado, } \\
\text { mas este ano, quando fomos montar os projetos, já } \\
\text { veio uma norma da Delegacia de Ensino dizendo que } \\
\text { não pode montar um projeto, em hipótese alguma, que } \\
\text { envolva lazer. Este parque novo de Jundiai, levar no } \\
\text { SESC... mesmo se você quiser direcionar o projeto e } \\
\text { fazer uma aula passeio, você tem que envolver vários } \\
\text { disciplinas. Eu acho que restringe um pouco. Esta não } \\
\text { é uma norma da escola, mas da Delegacia e eu acho } \\
\text { que não há um bom entendimento. }\end{array}$ \\
\hline
\end{tabular}




\begin{tabular}{|c|c|c|}
\hline \multicolumn{3}{|c|}{ DISCURSO 7 - CATEGORIAS, TEMAS E EXPRESSÕES CHAVE } \\
\hline CATEGORIA & TEMAS E SUB-TEMAS & EXPRESSÕES CHAVE \\
\hline \multirow[t]{2}{*}{$\begin{array}{l}\text { 1. CARACTERÍSTICAS } \\
\text { DE UMA BOA ESCOLA }\end{array}$} & $\begin{array}{l}\text { 1.1. Ambiente fisico de boa qualidade } \\
\text { (escola limpa) }\end{array}$ & $\begin{array}{l}\text { A escola oferece um ambiente limpo, decente para as } \\
\text { crianças. A gente sempre vai recuperando, } \\
\text { consertando, .não dá para estudar dentro de uma lata } \\
\text { de lixo. O ambiente é muito bom...já dei aula em } \\
\text { escola em que a coisa era terrivel. }\end{array}$ \\
\hline & $\begin{array}{l}\text { 1.2. Gestão escolar } \\
\text { 1.2.1. Adesão da comunidade escolar ao projeto } \\
\text { da escola (participa de sua implementação) }\end{array}$ & $\begin{array}{l}\text { A escola é melhor que a média que a gente vê aqui em } \\
\text { Carapicuiba, ela é boa. É boa porque a comunidade } \\
\text { participa do nosso trabalho, acredita nele e } \\
\text { acompanha os resultados da criança e a gente insiste } \\
\text { muito . Fazemos as reuniões bimestrais e se há } \\
\text { qualquer problema, os pais são chamados. A resposta } \\
\text { dos pais é sempre muito boa. Eu não sei se eles } \\
\text { respondem porque são mais abertos, são bons, ou } \\
\text { porque nós somos insistentes, mas a resposta deles é } \\
\text { boa. A escola se relaciona muito bem com a } \\
\text { comunidade ... Temos alunos pobres e precisamos } \\
\text { providenciar roupa, sapato .... ai por fora, é a lei do } \\
\text { cão. Aqui não .... gente precisa até pedir que as } \\
\text { pessoas não tragam mais nada. Nós temos muitos } \\
\text { imigrantes nordestinos aqui - quem vem para esta vila } \\
\text { tem até maiores condições - um arruma emprego para } \\
\text { outro, conta onde tem bico. }\end{array}$ \\
\hline
\end{tabular}




\begin{tabular}{|c|c|c|}
\hline \multicolumn{3}{|c|}{ DISCURSO 7 - CATEGORIAS, TEMAS E EXPRESSÕES CHAVE } \\
\hline CATEGORIA & TEMAS E SUB-TEMAS & EXPRESSŌES CHAVE \\
\hline \multirow[t]{3}{*}{$\begin{array}{l}\text { 1. CARACTERÍSTICAS } \\
\text { DE UMA BOA ESCOLA }\end{array}$} & $\begin{array}{l}\text { 1.2.2. Escola historicamente comprometida com } \\
\text { a melhoria da qualidade }\end{array}$ & $\begin{array}{l}\text { O principal fator é que esta escola é de descendentes } \\
\text { de um grupo de italianos ...mesmo que a clientela } \\
\text { tenha variado, eles tem conseguido manter essa coisa } \\
\text { do início. A clientela é diferente do resto do municipio } \\
\text { - há moradores mais antigos e os que chegam vão } \\
\text { aprendendo com eles. É uma escola antiga , que já tem } \\
\text { uma história e isto ajuda muito. }\end{array}$ \\
\hline & $\begin{array}{l}\text { 1.2.3. Seriedade e profissionalismo da equipe } \\
\text { escolar }\end{array}$ & $\begin{array}{l}\text { A escola é boa também porque tem bons professores } \\
\text { Eles não enxergam a escola como um emprego, mas } \\
\text { também não acham que isto é sacerdócio. } \\
\text { Trabalhamos sério e merecemos nosso salário. Esta } \\
\text { escola é assim. Somos respeitados pelos pais - nem } \\
\text { todas as escolas são. }\end{array}$ \\
\hline & $\begin{array}{l}\text { 1.3. Qualidade de ensino } \\
\text { 1.3..1. A família dos professores e funcionários } \\
\text { confia na qualidade do trabalho da escola } \\
\text { (filhos, sobrinhos e netos estudam na escola }\end{array}$ & $\begin{array}{l}\text { Meus filhos estudaram aqui, minha filha ainda estuda. } \\
\text { Eu tenho interesse que a escola seja boa. Se não fosse } \\
\text { boa, quem colocaria os filhos para estudar aqui } \\
\text { dentro? }\end{array}$ \\
\hline $\begin{array}{l}\text { 2. CARACTERISTICAS } \\
\text { DE UMA ESCOLA } \\
\text { SAUDÁVEL }\end{array}$ & \begin{tabular}{|l} 
2.1.Ambientes e/ou espaços da escola \\
particularmente saudáveis \\
2.1.1. refeitório
\end{tabular} & $\begin{array}{l}\text { No refeitório então, eles mostram o que estão } \\
\text { aprendendo. Não tem ninguém vigiando - eles se } \\
\text { alimentam, eles conversam, eles deixam o local } \\
\text { sempre muito limpo....eles exercitam o que } \\
\text { aprenderam } \\
\text { As salas de aula são uma prova de que esta escola é é } \\
\text { saudável ...lá acontecem as coisas, lá os alunos } \\
\text { aprendem a aprender, a respeitar o outro, ganham } \\
\text { auto-estima. Lá acho que eles são felizes e eu vejo que } \\
\text { não acontece isto só com os pequenos. }\end{array}$ \\
\hline
\end{tabular}




\begin{tabular}{|c|c|c|}
\hline \multicolumn{3}{|c|}{ DISCURSO 7 - CATEGORIAS, TEMAS E EXPRESSÓES CHAVE } \\
\hline CATEGORIA & TEMAS E SUB-TEMAS & EXPRESSŐES CHAVE \\
\hline \multirow[t]{3}{*}{$\begin{array}{l}\text { 2. CARACTERÍSTICAS } \\
\text { DE UMA ESCOLA } \\
\text { SAUDÁVEL }\end{array}$} & 2.1.3. biblioteca & $\begin{array}{l}\text { Na biblioteca, outra prova de que as coisas acontecem } \\
\text { bem. Há muitos livros, há quem oriente os alunos nas } \\
\text { pesquisas, quem indique alguma coisa interessante } \\
\text { para ler ...lá eles fazem trabalho em grupo. Mesmo os } \\
\text { que não têm nenhuma chance de ler em casa, podem } \\
\text { encontrar esta possibilidade aqui. }\end{array}$ \\
\hline & $\begin{array}{l}\text { 2.2. Gestão escolar } \\
\text { 2.2.1. Adesão da comunidade ao projeto da } \\
\text { escola (participa da implementação) }\end{array}$ & $\begin{array}{l}\text { A comunidade precisa comprar o projeto da escola - } \\
\text { precisa ter respeito pela escola, por tudo- prédio e } \\
\text { funcionários. Aqui não tem professorinha. Tem } \\
\text { professora. A gente já conquistou isto. É muito } \\
\text { gostoso você ver o seu trabalho reconhecido. }\end{array}$ \\
\hline & $\begin{array}{l}\text { 2.3. Qualidade do ensino } \\
\text { 2.3.1.Bons resultados de rendimento e } \\
\text { desempenho escolar }\end{array}$ & $\begin{array}{l}\text { Os nossos alunos aprendem e dá muita satisfação de } \\
\text { ver como vão progredindo ... eu sempre encontro } \\
\text { meus ex-alunos, aqui mesmo na escola, e pergunto } \\
\text { sobre como eles estão se saindo. E eles se saem bem } \\
\text {...é lógico que um ou outro nem vai tão bem assim. }\end{array}$ \\
\hline $\begin{array}{l}\text { 3. PAPEL DA ESCOLA } \\
\text { NA ÁREA DA SAÚDE }\end{array}$ & $\begin{array}{l}\text { 3.1. promoção da saúde pela articulação da teoria } \\
\text { com a prática }\end{array}$ & $\begin{array}{l}\text { A escola promove a saúde das crianças, mas este } \\
\text { papel às vezes fica como quebra galho. Não adianta } \\
\text { saber ler, escrever, se não tiver hábitos de higiene. } \\
\text { Esta coisa de formação é necessária. Por exemplo, o } \\
\text { flúor - uma vez por semana nós fazemos isto aqui - os } \\
\text { alunos levam a escova para casa. Mas precisamos } \\
\text { ensinar bem - o resto complementa o nosso trabalho. } \\
\text { Precisamos de crianças sadias - não posso trabalhar } \\
\text { com criança com dor de dente, com piolho, com dor } \\
\text { de barriga - então temos que trabalhar com isto }\end{array}$ \\
\hline
\end{tabular}




\begin{tabular}{|c|c|c|}
\hline \multicolumn{3}{|c|}{ DISCURSO 7 - CATEGORIAS, TEMAS E EXPRESSŌES CHAVE } \\
\hline CATEGORIA & TEMAS E SUB-TEMAS & EXPRESSÕES CHAVE \\
\hline $\begin{array}{l}\text { 3. PAPEL DA ESCOLA } \\
\text { NA ÁREA DA SAÚDE }\end{array}$ & 3.2 formação de valores & $\begin{array}{l}\text { Nós trabalhamos a formação de hábitos de higiene, } \\
\text { mas damos muita importância para que os alunos } \\
\text { exercitem criar um ambiente em que um respeita o } \\
\text { outro ...Aqui a gente procura fazer isto, pois damos } \\
\text { muita importância a isto ......eu trabalho assim - eu } \\
\text { exijo respeito, eu respeito...eu gosto de disciplina .... } \\
\text { as crianças têm que saber o que é direito, o que é } \\
\text { dever. Antes de ser político, o ser é humano - e isto } \\
\text { nós trabalhos muito aqui. Um precisa ajudar o outro - } \\
\text { estes valores são cultivados aqui. Na minha sala, a } \\
\text { gente trabalha assim ...e também a escola toda. }\end{array}$ \\
\hline \multirow[t]{2}{*}{$\begin{array}{l}\text { 4. CARACTERISTICAS } \\
\text { DO PROCESSO DE } \\
\text { CONSTRUÇÃO DE UMA } \\
\text { ESCOLA SAUDÁVEL }\end{array}$} & $\begin{array}{l}\text { 4.1. Tempo de construção de uma escola } \\
\text { saudável } \\
\text { 4.1.1. Não é possivel prever, pois o processo é } \\
\text { contínuo }\end{array}$ & $\begin{array}{l}\text { E um trabalho da vida inteira. Precisa acompanhar, } \\
\text { verificar os resultados, corrigir... }\end{array}$ \\
\hline & $\begin{array}{l}\text { 4.2. Condições essenciais para a construção de } \\
\text { uma escola saudável } \\
\text { 4.2.1. Vontade de querer fazer } \\
\begin{array}{l}\text { 4.2.2. Necessidade de abandonar a cultura do } \\
\text { fracasso escolar em favor da cultura do sucesso } \\
\text { escolar }\end{array}\end{array}$ & $\begin{array}{l}\text { Precisa de boa vontade de todo mundo - dos pais, dos } \\
\text { alunos - os alunos vão seguir o exemplo dos } \\
\text { professores, vão seguir o modelo da escola.. } \\
\text { Precisa mudar o conceito de escola - nosso país rotula } \\
\text { tudo - a nossa escola não está fracassada. Para } \\
\text { começar, uma escola saudável precisa ser acreditada. } \\
\text { Se os professores não acreditam, se os pais não } \\
\text { acreditam, os filhos também não acreditam. Precisa } \\
\text { mudar esta imagem da escola. }\end{array}$ \\
\hline
\end{tabular}




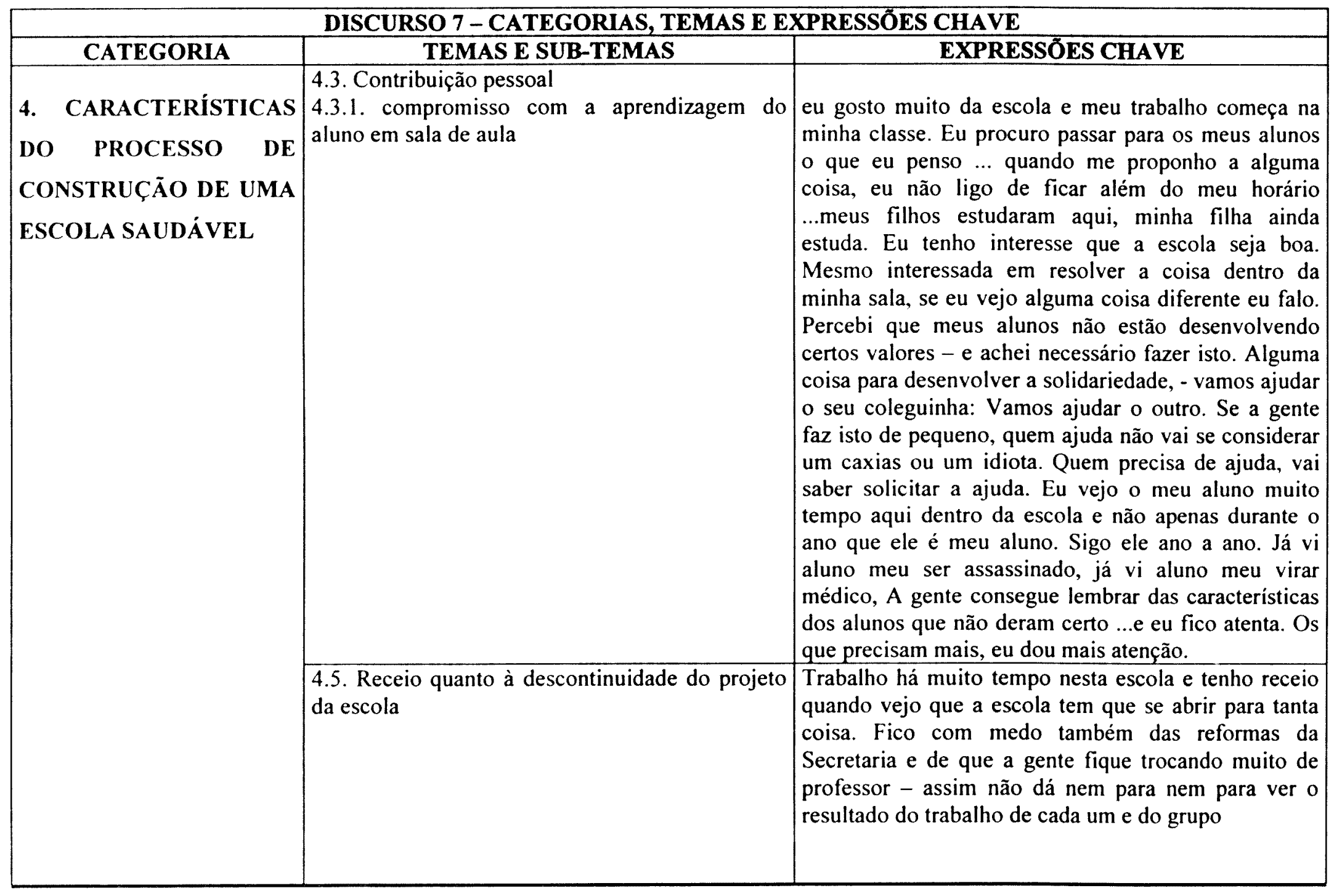




\begin{tabular}{|c|c|c|}
\hline \multicolumn{3}{|c|}{ DISCURSO 8-CATEGORIAS, TEMAS E EXPRESSŌES CHAVE } \\
\hline CATEGORIA & TEMAS E SUB-TEMAS & EXPRESSÕES CHAVE \\
\hline \multirow[t]{2}{*}{$\begin{array}{l}\text { 1. CARACTERISTICAS } \\
\text { DE UMA BOA ESCOLA }\end{array}$} & $\begin{array}{l}\text { 1.1. Estrutura e ambiente fisico de boa qualidade } \\
\text { (bom estado de conservação, limpeza, } \\
\text { arborização) }\end{array}$ & $\begin{array}{l}\text { O prédio e a conservação dele deixam qualquer outra } \\
\text { escola com inveja. Muito verde, muita flor, muita } \\
\text { ordem, muita limpeza... também muito trabalho sério } \\
\text { e pessoas felizes aqui dentro. }\end{array}$ \\
\hline & $\begin{array}{l}\text { 1.2. Gestão escolar } \\
\text { 1.2.1. Projeto escolar claramente definido e } \\
\text { conhecido pela comunidade escolar } \\
\text { 1.2.2. Adesão da comunidade escolar ao projeto } \\
\text { da escola(participa de sua implementação) }\end{array}$ & $\begin{array}{l}\text { A escola tem um projeto que todos conhecem, } \\
\text { inclusive a comunidade. Nós sabemos o que } \\
\text { queremos. A escola é séria, muito séria. mas não é } \\
\text { carrancuda, nem chata - é só séria } \\
\text { A participação dos pais na escola é caracteristica do } \\
\text { Fornasaro - a participação dos pais é diferente, porque } \\
\text { eles têm e demonstram muito carinho. Respeitam o } \\
\text { nosso trabalho e a escola em si, o prédio. Numa outra } \\
\text { escola que lecionei, sai em junho e a escola já havia } \\
\text { sido assaltada } 14 \text { vezes. Aqui não tem isso. Eles } \\
\text { ajudam a fazer o que tem que ser feito, o que foi } \\
\text { planejado. Ajudam a escola a ser boa. } \\
\text { Acho que esta é uma ótima escola, porque aqui tudo } \\
\text { funciona, principalmente a direção e o apoio } \\
\text { pedagógico. Elas estão sempre aqui, a qualquer hora e } \\
\text { isto facilita o nosso trabalho. A direção é sempre } \\
\text { pronta, muito presente, muito dedicada e competente. } \\
\text { O mesmo eu digo da coordenadora. }\end{array}$ \\
\hline
\end{tabular}




\begin{tabular}{|c|c|c|}
\hline \multicolumn{3}{|c|}{ DISCURSO 8-CATEGORIAS, TEMAS E EXPRESSÕES CHAVE } \\
\hline CATEGORIA & TEMAS E SUB-TEMAS & EXPRESSỐES CHAVE \\
\hline \multirow[t]{3}{*}{$\begin{array}{l}\text { 1. CARACTERISTICAS } \\
\text { DE UMA BOA ESCOLA }\end{array}$} & $\begin{array}{l}\text { 1.2.4. Escola historicamente comprometida com } \\
\text { a melhoria da qualidade }\end{array}$ & $\begin{array}{l}\text { Esta é uma escola antiga, com um projeto que foi se } \\
\text { acertando aos poucos. Há pessoas que trabalham } \\
\text { juntas há mais de } 15 \text { anos ...ninguém está só de } \\
\text { passagem pela escola, só até arrumar uma coisa } \\
\text { melhor. Esta história da escola conta muito para que } \\
\text { ela vá se aperfeiçoando cada vez mais. }\end{array}$ \\
\hline & 1.2.5. Entrosamento entre os elementos da equipe & $\begin{array}{l}\text { A escola é boa porque há muito coleguismo aqui...as } \\
\text { pessoas estão bem entrosadas, se respeitam muito. } \\
\text { Quando é necessário, um ajuda o outro, até } \\
\text { profissionalmente. Nós trocamos idéias, contamos } \\
\text { como foi trabalhar desta ou daquela maneira com uma } \\
\text { série ... }\end{array}$ \\
\hline & $\begin{array}{l}\text { 1.3. Qualidade de ensino } \\
\text { 1.3.1. bons resultados de rendimento e } \\
\text { desempenho escolar }\end{array}$ & $\begin{array}{l}\text { Não há escola que não esteja passando por dificuldade } \\
\text { para oferecer uma excelente qualidade de ensino. } \\
\text { Acho que temos muito que fazer, mas os nossos } \\
\text { alunos saem daqui em melhor condição do que muitos } \\
\text { de outras escolas. } \\
\text { Eu já falei um pouco disso, mas acho que vale a pena } \\
\text { reforçar. Em muitas escolas, os professores ficam } \\
\text { inventando o que fazer nas HTPCs. Nós aprendemos a } \\
\text { usar bem este tempo, trocando idéias sobre o que cada } \\
\text { um fez na sua sala e deu certo, combinando o que } \\
\text { cada um vai dar em sua disciplina, conversando sobre } \\
\text { os alunos que estão com problemas de aprender ou } \\
\text { mesmo de disciplina. Acho que a gente vai se } \\
\text { aperfeiçoando e as aulas é que ganham ...os alunos, na } \\
\text { verdade. }\end{array}$ \\
\hline
\end{tabular}




\begin{tabular}{|c|c|c|}
\hline \multicolumn{3}{|c|}{ DISCURSO \& - CATEGORIAS, TEMAS E EXPRESSŌES CHAVE } \\
\hline CATEGORIA & TEMAS E SUB-TEMAS & EXPRESSÓES CHAVE \\
\hline $\begin{array}{l}\text { 1. CARACTERISTICAS } \\
\text { DE UMA BOA ESCOLA }\end{array}$ & $\begin{array}{l}\text { 1.3.3. A familia dos professores e funcionários } \\
\text { confia na qualidade do trabalho da escola } \\
\text { (filhos, sobrinhos e netos estudam na escola }\end{array}$ & $\begin{array}{l}\text { Você pode perguntar por aí quantos professores põem } \\
\text { os filhos para estudar na escola onde trabalham. Eles } \\
\text { podem até falar que a escola é boa, mas põem seus } \\
\text { filhos na escola particular. Nossos filhos estudam } \\
\text { nesta escola - quer maior prova de que ela é boa e } \\
\text { saudável? Minhas duas filhas estudaram aqui } \\
\text {...quando estavam no colegial, eu vinha de Osasco } \\
\text { duas vezes - de manhã, para dar aula e à noite, para } \\
\text { trazer e buscar as meninas. É amor ...é confiança. }\end{array}$ \\
\hline \multirow{3}{*}{$\begin{array}{l}\text { 2. CARACTERISTICAS } \\
\text { DE UMA ESCOLA } \\
\text { SAUDÁVEL }\end{array}$} & $\begin{array}{l}\text { 2.1. Ambiente fisico de boa qualidade } \\
\text { (escola limpa, bem construida, arborizada) }\end{array}$ & $\begin{array}{l}\text { A escola é muito saudável ...basta dar uma volta e } \\
\text { verificar: ela é limpa, desde as salas de aula até o } \\
\text { refeitório...o prédio é bem construido.... a escola é } \\
\text { muito arborizada. }\end{array}$ \\
\hline & $\begin{array}{l}\text { 2.2. Ambientes e/ou espaços da escola } \\
\text { particularmente saudáveis } \\
\text { 2.2.1. refeitório }\end{array}$ & $\begin{array}{l}\text { O refeitório da escola é um modelo e um cartão de } \\
\text { visita - é claro que aqui os nossos alunos são } \\
\text { respeitados, também porque eles se alimentam num } \\
\text { lugar saudável...nós não humilhamos os alunos } \\
\text { oferecendo-lhes comida num ambiente inadequado.. }\end{array}$ \\
\hline & $\begin{array}{l}\text { 2.3. Gestão escolar } \\
\text { 2.3.1. Clima amigável e boa organização geral }\end{array}$ & $\begin{array}{l}\text { O clima da escola é muito bom. Há respeito e } \\
\text { praticamente não há violência. Aqui nós podemos } \\
\text { trabalhar em paz e ultimamente não dá para falar isto } \\
\text { de todas as escolas. }\end{array}$ \\
\hline
\end{tabular}




\begin{tabular}{|c|c|c|}
\hline \multicolumn{3}{|c|}{ DISCURSO 8-CATEGORIAS, TEMAS E EXPRESSÕES CHAVE } \\
\hline CATEGORIA & TEMAS E SUB-TEMAS & EXPRESSŌES CHAVE \\
\hline \multirow[t]{3}{*}{$\begin{array}{l}\text { 3. PAPEL DA ESCOLA } \\
\text { NA ÁREA DA SAÚDE }\end{array}$} & $\begin{array}{l}\text { 3.1. promoção da saúde pela articulação da teoria } \\
\text { com a prática }\end{array}$ & $\begin{array}{l}\text { Esta escola faz um bom trabalho na área de saúde, } \\
\text { inclusive no que se refere aos conteúdos. Desde as } \\
\text { séries iniciais, trabalhamos com higiene, sexualidade. } \\
\text { Zelamos para que os menores tomem banho, } \\
\text { ensinamos como usar MODESS...juntamos a teoria } \\
\text { com a prática. Orientamos os alunos para que tenham } \\
\text { nas escola uma referência ...a escola é uma extensão } \\
\text { da casa e nós orientamos assim nossos alunos. Temos } \\
\text { que conservar a escola como conservamos a nossa } \\
\text { casa. }\end{array}$ \\
\hline & 3.2. orientação de pais e de alunos & $\begin{array}{l}\text { A escola precisa orientar os alunos e os pais. É alguma } \\
\text { coisa a mais do que apenas informar - informar } \\
\text { também, mas discutir alguns pontos práticos que } \\
\text { podem melhorar a vida deles e a vida da escola. }\end{array}$ \\
\hline & $\begin{array}{l}\text { 3.3. encaminhamento dos alunos aos serviços de } \\
\text { saúde }\end{array}$ & $\begin{array}{l}\text { Não temos assistência médica e odontológica na } \\
\text { escola, mas não podemos lavar as mãos quando os } \\
\text { nossos alunos estão doentes. Nós encaminhamos os } \\
\text { alunos com problemas para o postinho - é sempre } \\
\text { melhor que nada. }\end{array}$ \\
\hline $\begin{array}{l}\text { 4. PROCESSO DE } \\
\text { CONSTRUÇÃO DE UMA } \\
\text { ESCOLA SAUDÁVEL }\end{array}$ & $\begin{array}{l}\text { 4.1. Tempo de construção de uma escola } \\
\text { saudável } \\
\text { 4.1.1. Não há como fixar duração. pois o } \\
\text { prucesso c contmuo }\end{array}$ & $\begin{array}{l}\text { Este é um trabalho de longo tempo. Estamos hoje } \\
\text { colhendo os frutos de um trabalho que foi iniciado há } \\
\text { muito tempo atrás. Não podemos deixar a peteca cair } \\
\ldots \text { temos que continuar com a qualidade. Há escolas } \\
\text { por ai que são um horror. }\end{array}$ \\
\hline & 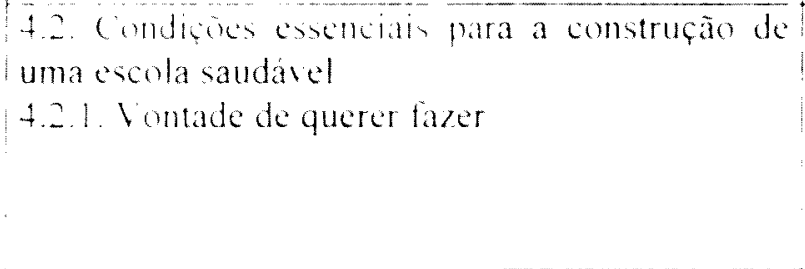 & 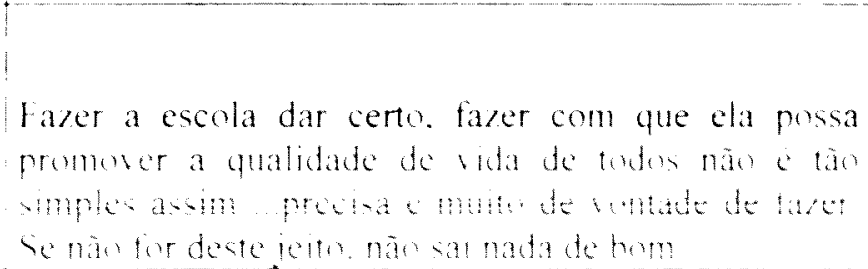 \\
\hline
\end{tabular}




\begin{tabular}{|c|c|c|}
\hline \multicolumn{3}{|c|}{ DISCURSO 8-CATEGORIAS, TEMAS E EXPRESSŌES CHAVE } \\
\hline CATEGORIA & TEMAS E SUB-TEMAS & EXPRESSÕES CHAVE \\
\hline \multirow[t]{2}{*}{$\begin{array}{l}\text { 4. PROCESSO DE } \\
\text { CONSTRUÇÃO DE UMA } \\
\text { ESCOLA SAUDÁVEL }\end{array}$} & $\begin{array}{l}\text { 4.2.2. Processo compartilhado entre todos, } \\
\text { inclusive com a comunidade }\end{array}$ & $\begin{array}{l}\text { E fundamental a participação de todos... comunidade, } \\
\text { funcionários, professores, alunos. A escola é de todos } \\
\text { e só funciona bem quando estiver muito articulada à à } \\
\text { comunidade. Aqui, nós temos muito a participação } \\
\text { dos pais e isto tem sido fundamental. Os pais estão } \\
\text { dentro da escola - na APM, no Conselho de Escola } \\
\text {..tenho muitos amigos que foram os pais dos meus } \\
\text { alunos. Há um elo muito grande entre os professores, } \\
\text { os alunos e os pais. Por isto é que esta escola é ótima. }\end{array}$ \\
\hline & $\begin{array}{l}\text { 4.3. Contribuição pessoal } \\
\text { 4.3.1. Foco do trabalho pedagógico é a } \\
\text { permanência do aluno na escola e sua } \\
\text { aprendizagem efetiva }\end{array}$ & $\begin{array}{l}\text { Sou profissional e tenho amor naquilo que faço. Para } \\
\text { lidar com crianças, precisa ter amor. Tenho amor } \\
\text { pelas crianças - respeito as crianças e trabalho para } \\
\text { elas. Faço o que posso e o que não posso para que o } \\
\text { nosso trabalho seja interessante, para que elas se } \\
\text { sintam bem na escola, para que possam progredir e se } \\
\text { realizar na vida. O objetivo do meu trabalho são as } \\
\text { crianças e acho que esta é a minha contribuição pessoa } \\
\text { para que a escola seja boa e saudável. Pode parecer } \\
\text { pouco, mas se todos fizerem bem a sua parte, as coisas } \\
\text { vão entrando nos eixos, como aqui no Fornasaro. }\end{array}$ \\
\hline
\end{tabular}




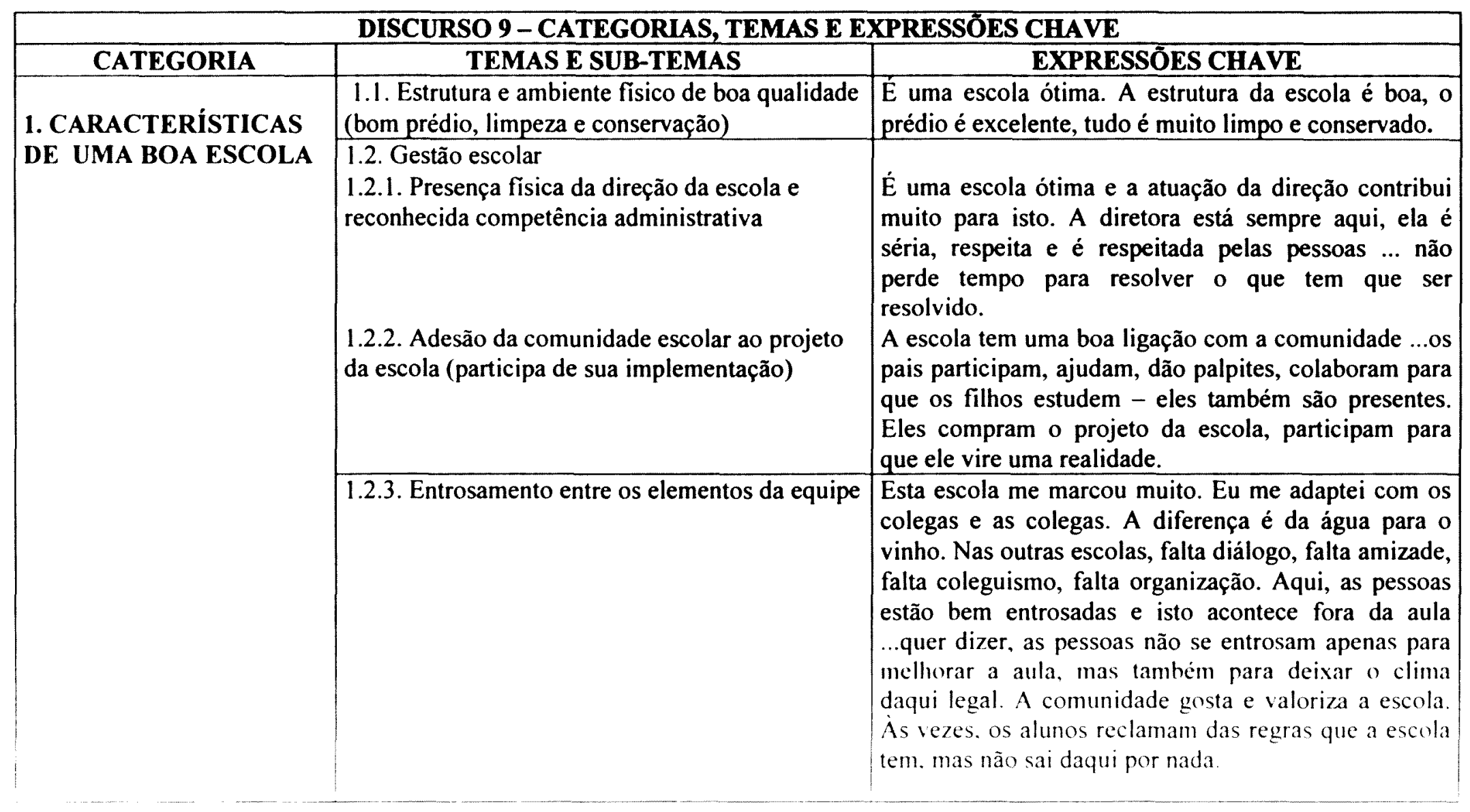




\begin{tabular}{|c|c|c|}
\hline \multicolumn{3}{|c|}{ DISCURSO 9 - CATEGORIAS, TEMAS E EXPRESSŌES CHAVE } \\
\hline CATEGORIA & TEMAS E SUB-TEMAS & EXPRESSÕES CHAVE \\
\hline \multirow[t]{2}{*}{$\begin{array}{l}\text { 2. CARACTERÍSTICAS } \\
\text { DE UMA ESCOLA } \\
\text { SAUDÁVEL }\end{array}$} & 2.1. Ambiente fisico de boa qualidade & $\begin{array}{l}\text { A escola é saudável, mas faltam palavras para dizer } \\
\text { porquê na minha cabeça eu sei, mas eu não sei dizer. } \\
\text { É dificil ter reclamaçôes. Dê uma olhada na sala dos } \\
\text { professores ...limpa, aconchegante, com condições } \\
\text { para a gente fazer um belo trabalho coletivo ...olhe as } \\
\text { nossas salas de aula, os nossos corredores. Alguma } \\
\text { dúvida que esta é uma escola saudável?! } \\
\text { Não há alunos com drogas. O ambiente da escola é } \\
\text { muito bom, ela é arborizada, é limpa, tem biblioteca } \\
\text { excelente, uma quadra boa. }\end{array}$ \\
\hline & $\begin{array}{l}\text { 2.2. Gestão escolar } \\
\text { 2.2.1. Presença fisica da direção na escola e } \\
\text { reconhecida competência administrativa }\end{array}$ & $\begin{array}{l}\text { A direção é muito boa e isto influi muito. Ela está } \\
\text { sempre na escola e sabe comandar as coisas. Ela } \\
\text { articula tudo muito bem e consegue não pressionar } \\
\text { muito, pois isto deixa as pessoas mais tensas e a coisa } \\
\text { não anda }\end{array}$ \\
\hline $\begin{array}{l}\text { 3. PAPEL DA ESCOLA } \\
\text { NA ÁREA DA SAÚDE }\end{array}$ & 3.1. Prevenção & $\begin{array}{l}\text { O papel da escola é a prevenção. Prevenir o aluno } \\
\text { contra qualquer tipo de doença, droga. Faço sempre } \\
\text { isto com meus alunos ..passo conteúdos, discuto.. }\end{array}$ \\
\hline \multirow[t]{2}{*}{$\begin{array}{l}\text { 4. PROCESSO DE } \\
\text { CONSTRUÇÃO DE UMA } \\
\text { ESCOLA SAUDÁVEL }\end{array}$} & $\begin{array}{l}\begin{array}{l}\text { 4.1. Tempo de construção de uma escola } \\
\text { saudável }\end{array} \\
\text { 4.1.1.não há como fixar duração: processo é } \\
\text { continuo }\end{array}$ & $\begin{array}{l}\text { Acho que leva muito tempo e exige um diálogo } \\
\text { constante em pais, alunos e professores. Os pais } \\
\text { precisam participar muito. como acontece aqui. Eles } \\
\text { gostam da escola, eles procuram a escola. todos } \\
\text { querem se transferir para cá. }\end{array}$ \\
\hline & $\begin{array}{l}\text { 4.2. Condiçoes essenciais para a construção de } \\
\text { uma escola saudale! } \\
\text { 4.2.1 Boa estrutura da escola }\end{array}$ & 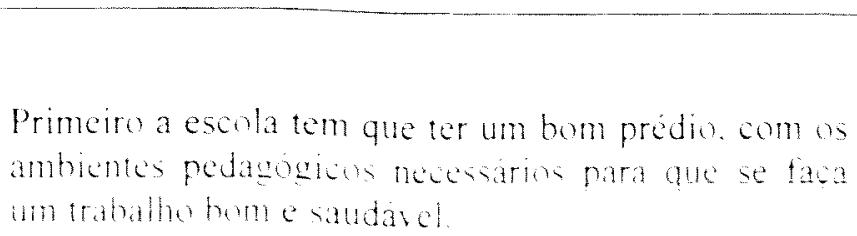 \\
\hline
\end{tabular}




\begin{tabular}{|c|c|c|}
\hline \multicolumn{3}{|c|}{ DISCURSO 9-CATEGORIAS, TEMAS E EXPRESSŌES CHAVE } \\
\hline CATEGORIA & \begin{tabular}{|l|} 
TEMAS E SUB-TEMAS \\
\end{tabular} & \begin{tabular}{|r|} 
EXPRESSOESS CHAVE \\
\end{tabular} \\
\hline $\begin{array}{l}\text { 4. PROCESSO DE } \\
\text { CONSTRUÇÃO DE UMA } \\
\text { ESCOLA SAUDÁVEL }\end{array}$ & $\begin{array}{l}\text { 4.2.1. Contribuição pessoal } \\
\text { 4.2.1.1. Ampliação das oportunidades de } \\
\text { participação em jogos e competições }\end{array}$ & $\begin{array}{l}\text { Acho que me esforço muito para que a escola seja } \\
\text { saudável. Os meus alunos sempre participaram de } \\
\text { campeonatos ...sempre fomos premiados e nos } \\
\text { destacamos em todas as competições. Participamos } \\
\text { nos Jogos Municipais, nos Jogos da Caixa .... Eles } \\
\text { ficavam sempre muito satisfeitos ... alguns não se } \\
\text { tocavam e não queriam participar. É dificil trazer este } \\
\text { pessoa para a quadra, mas a participação geral sempre } \\
\text { foi boa. Os pais ficavam sempre muito satisfeitos com } \\
\text { os resultados e isso os aproximava mais ainda da } \\
\text { escola. }\end{array}$ \\
\hline
\end{tabular}




\begin{tabular}{|c|c|c|}
\hline \multicolumn{3}{|c|}{ DISCURSO 10 - CATEGORIAS, TEMAS E EXPRESSŌES CHAVE } \\
\hline CATEGORIA & TEMAS E SUB-TEMAS & EXPRESSÕES CHAVE \\
\hline $\begin{array}{l}\text { 1. CARACTERÍSTICAS } \\
\text { DE UMA BOA ESCOLA }\end{array}$ & 1.1. Estrutura e ambiente fisico de boa qualidade & $\begin{array}{l}\text { Esta escola é muito boa. Para começar, é limpa, bem } \\
\text { construida, arejada, arborizada. Dá gosto de andar por } \\
\text { aqui ...ela é esteticamente bonita e tem até gente que } \\
\text { fica perguntando se ela é mesmo uma escola estadual. }\end{array}$ \\
\hline & $\begin{array}{l}\text { 1.2. Gestão escolar } \\
\text { 1.2.1. Adesão da comunidade escolar ao projeto } \\
\text { da escola (participa de sua implementação) }\end{array}$ & $\begin{array}{l}\text { Nós não somos sozinhos aqui dentro, pois } \\
\text { trabalhamos com a comunidade. Ela é muito presente } \\
\text { e colabora para que o projeto da escola ande bem. Os } \\
\text { alunos daqui também participam mais, tem uma } \\
\text { atuação diferente. Não sei se é o grupo de professores, } \\
\text { se são os pais, se sé a direção ...acho que é o trabalho } \\
\text { de todos e também a comunidade é muito } \\
\text { participativa. Como já disse os pais estão sempre } \\
\text { colaborando com a escola conhece o projeto da escola, } \\
\text { aprova este projeto e contribui para que ele seja posto } \\
\text { m prática. Esta participação da comunidade tem sido } \\
\text { muito importante para que a escola faça um bom } \\
\text { trabalho. Lá fora, temos muita violência que e há } \\
\text { professores que são ameaçados e escolas que são } \\
\text { depredadas. Graças a Deus isto não acontece aqui ... } \\
\text { comunidade protege o Fornasaro. Não quero passar a } \\
\text { impressão que não temos problemas ... temos, mas a } \\
\text { gente sempre procura uma solução. A comunidade } \\
\text { não é o nosso problema. mas a nossa solução ...e cu } \\
\text { contheço escolas cujo mainr problema é a comunidade. }\end{array}$ \\
\hline
\end{tabular}




\begin{tabular}{|c|c|c|c|}
\hline \multirow{6}{*}{ 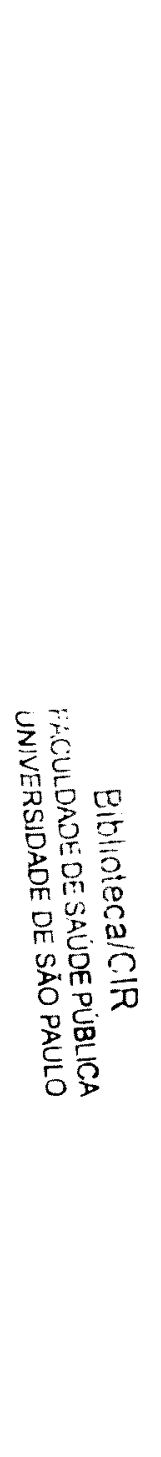 } & \multicolumn{3}{|c|}{ DISCURSO 10 - CATEGORIAS, TEMAS E EXPRESSŐES CHAVE } \\
\hline & CATEGORIA & $\begin{array}{l}\text { TEMAS E SUB-TEMAS } \\
\end{array}$ & EXPRESSŌES CHAVE \\
\hline & $\begin{array}{l}\text { 1. CARACTERISTICAS } \\
\text { DE UMA BOA ESCOLA }\end{array}$ & $\begin{array}{l}\text { 1.3.1. Bons resultados de rendimento e } \\
\text { desempenho escolar }\end{array}$ & $\begin{array}{l}\text { Não dá para falar em boa escola se a gente não fala } \\
\text { que os alunos aprendem... temos também dificuldades, } \\
\text { os alunos não são iguais, as classes também, mas os } \\
\text { alunos têm um bom rendimento. Eles se saem bem } \\
\text { aqui e fora daqui também ... acho que a escola está } \\
\text { acertando no que faz. }\end{array}$ \\
\hline & $\begin{array}{l}\text { 2. CARACTERÍSTICAS } \\
\text { DE UMA ESCOLA } \\
\text { SAUDÁVEL }\end{array}$ & 2.1. Ambiente fisico de boa qualidade & $\begin{array}{l}\text { Em relação ao espaço fisico, é uma escola arborizada, } \\
\text { limpa, conservada e isto ajuda bastante. Quando o } \\
\text { aluno vê a escola limpa, organizada, isto ajuda muito e } \\
\text { melhora até a maneira como ele age na sala de aula. } \\
\text { Isto ajuda muito na relação com o aluno e no coletivo. }\end{array}$ \\
\hline & & $\begin{array}{l}\text { 2.2. Ambientes e/ou espaços da escola } \\
\text { particularmente saudáveis } \\
\text { 2.2.1. salão de eventos (salão de vídeo) } \\
\text { 2.2.2. sala dos professores } \\
\text { 2.2.3. biblioteca }\end{array}$ & $\begin{array}{l}\text { Veja também o nosso salão de eventos ...o espaço } \\
\text { sugere uma série de atividades que aproximam as } \\
\text { pessoas ...não é só por meio do teatro, mas do video, } \\
\text { da música ..... Até poderia dizer mais, mas acho que já } \\
\text { disse o que precisava. } \\
\text { Também a sala de professores é um lugar muito } \\
\text { saudável ...uma mesa grande, onde as pessoas sempre } \\
\text { estão se reunindo, trocando coisas ... um cantinho } \\
\text { mais aconchegante, que deixa a sala com a cara da } \\
\text { casa da gente. } \\
\text { A biblioteca daqui é muito boa ...há muitos livros, os } \\
\text { alunos freqüentam a biblioteca, podem crescer, } \\
\text { aproveitar o seu tempo, ampliar seus horizontes - e } \\
\text { isto é muito saudável. }\end{array}$ \\
\hline & & $\begin{array}{l}\text { 2.3. Gestão escolar } \\
\text { 2.3.1. Adesão da comunidade ao projeto da } \\
\text { escola }\end{array}$ & A comunidade apoia o trabalho da escola \\
\hline
\end{tabular}




\begin{tabular}{|c|c|c|}
\hline \multicolumn{3}{|c|}{ DISCURSO 10 - CATEGORIAS, TEMAS E EXPRESSÓES CHAVE } \\
\hline CATEGORIA & TEMAS E SUB-TEMAS & EXPRESSŐES CHAVE \\
\hline $\begin{array}{l}\text { 2. CARACTERÍSTICAS } \\
\text { DE UMA ESCOLA } \\
\text { SAUDÄVEL }\end{array}$ & $\begin{array}{l}\text { 2.4. Qualidade do ensino } \\
\text { 2.4.1. Bons resultados de rendimento e } \\
\text { desempenho escolar }\end{array}$ & $\begin{array}{l}\text { Acho que os alunos têm se saido bem aqui e fora } \\
\text { daqui }\end{array}$ \\
\hline $\begin{array}{l}\text { 3. PAPEL DA ESCOLA } \\
\text { NA ÁREA DA SAÚDE }\end{array}$ & $\begin{array}{l}\text { 3.1. transmissão de conhecimentos e de } \\
\text { referências no campo da saúde } \\
\text { 3.2. orientação de pais e de alunos } \\
\text { 3.3. encaminhamento dos alunos aos serviços de } \\
\text { saúde }\end{array}$ & $\begin{array}{l}\text { A escola tem um grande papel de estar colaborando } \\
\text { para que os alunos tenham os conhecimentos certos de } \\
\text { saúde. Na Educação Física... em Ciências isto } \\
\text { integrado com todas as outras disciplinas. A escola } \\
\text { precisa trabalhar conteúdos de saúde. Nas minhas } \\
\text { aulas eu sempre ajudo as outras professoras que estão } \\
\text { trabalhando com conteúdos de saúde. } \\
\text { Ela deve estar orientando tanto os alunos quanto os } \\
\text { pais. Ela deve estar ..como fala?! ...cuidando, tomando } \\
\text { cuidado da higiene, de uma forma geral. } \\
\text { Acho que a escola também deve esclarecer aos alunos } \\
\text { e às familias sobre como podem ser atendidos na } \\
\text { comunidade ...quem procurar em caso de necessidade. } \\
\text { Também devemos ficar atentos para perceber alguma } \\
\text { situação que a familia não percebeu e encaminhar. }\end{array}$ \\
\hline $\begin{array}{l}\text { 4. PROCESSO DE } \\
\text { CONSTRUÇÃO DE UMA } \\
\text { ESCOLA SAUDÁVEL }\end{array}$ & $\begin{array}{l}\text { 4.1. Tempo de construção de uma escola } \\
\text { saudável } \\
\text { 4.1.1. não há como fixar duração; processo é } \\
\text { continuo }\end{array}$ & $\begin{array}{l}\text { Não dá para se descuidar de nada quando a escola } \\
\text { quer ser saudável de verdade. Por isto acho que não dá } \\
\text { para dizer quanto tempo demora ...acho que é a vida } \\
\text { toda. }\end{array}$ \\
\hline
\end{tabular}




\begin{tabular}{|c|c|c|}
\hline \multicolumn{3}{|c|}{ DISCURSO 10 - CATEGORIAS, TEMAS E EXPRESSŌES CHAVE } \\
\hline CATEGORIA & TEMAS E SUB-TEMAS & EXPRESSŐES CHAVE \\
\hline \multirow{4}{*}{$\begin{array}{l}\text { 4. PROCESSO DE } \\
\text { CONSTRUÇÃO DE UMA } \\
\text { ESCOLA SAUDÁVEL }\end{array}$} & $\begin{array}{l}\text { 4.2. Condições essenciais para a construção de } \\
\text { uma escola saudável }\end{array}$ & \\
\hline & $\begin{array}{l}\text { 4.2.1. Processo compartilhado entre todos, } \\
\text { inclusive com a comunidade }\end{array}$ & $\begin{array}{l}\text { Em primeiro lugar, acho que todos precisam estar } \\
\text { sintonizados com um projeto único - e todos inclui } \\
\text { também a comunidade, conforme eu já falei. Se não } \\
\text { tiver este coletivo, não dá para querer mudar a escola } \\
\text { nara melhor }\end{array}$ \\
\hline & 4.2.2. Foco da escola é o sucesso escolar & $\begin{array}{l}\text { Acredito que o acesso à educação é uma das } \\
\text { condições para que um povo seja saudável. Assim, é } \\
\text { necessário que o aluno possa freqüentar uma escola, } \\
\text { qualquer que seja, pois é melhor uma escola que não é } \\
\text { muito boa do que nenhuma escola. Depois, o aluno } \\
\text { deve ter condições de poder ficar na escola ...deve ter } \\
\text { aulas interessantes...deve ter a sua realidade } \\
\text { considerada. Ele deve se sentir bem na escola, precisa } \\
\text { ser bem sucedido, precisa gostar dela. Vi um dado que } \\
\text { só o fato de uma pessoa saber ler já aumenta o tempo } \\
\text { de vida dela... se a escola faz mais ainda, se preocupa } \\
\text { com a saúde de dentre e de fora da escola, melhora } \\
\text { ainda mais. }\end{array}$ \\
\hline & $\begin{array}{l}\text { 4.3. Contribuição pessoal } \\
\text { 4.3.1. sintonia com a equipe }\end{array}$ & $\begin{array}{l}\text { Eu procuro estar sintonizada com tudo „, com o } \\
\text { trabalho, com o bom relacionamento com o aluno, } \\
\text { com os colegas, com a comunidade. }\end{array}$ \\
\hline
\end{tabular}




\begin{tabular}{|c|c|c|}
\hline \multicolumn{3}{|c|}{ DISCURSO 10 - CATEGORIAS, TEMAS E EXPRESSÓES CHAVE } \\
\hline CATEGORIA & TEMAS E SUB-TEMAS & EXPRESSŌES CHAVE \\
\hline \multirow[t]{2}{*}{$\begin{array}{l}\text { 4. PROCESSO DE } \\
\text { CONSTRUÇĀO DE UMA } \\
\text { ESCOLA SAUDÁVEL }\end{array}$} & $\begin{array}{l}\text { 4.3.2. compromisso com a realização de um bom } \\
\text { trabalho em sala de aula }\end{array}$ & $\begin{array}{l}\text { Estou sempre me aprimorando e busco trazer coisas } \\
\text { novas e interessantes para o aluno. Procuro o que tem } \\
\text { de bom por ai e trago para cá, fazendo com que o } \\
\text { aluno se expresse de várias maneiras, usando várias } \\
\text { linguagens...tem aquele aluno que não é bom numa } \\
\text { área, mas é bom em outra - se ele não é bom em } \\
\text { Música, ele é bom em outra coisa ...eu dou } \\
\text { oportunidades para que todos se sintam capazes } \\
\text {...para que eles se valorizem, tenham êxito, aceitem } \\
\text { as diferenças, contribuam para o coletivo. Também } \\
\text { busco interagir com os meus colegas, para que eles } \\
\text { aproveitem o que puderem das coisas que eu arranjo } \\
\text { fora. }\end{array}$ \\
\hline & $\begin{array}{l}\text { 4.4. Receio quanto à descontinuidade do projeto } \\
\text { da escola }\end{array}$ & $\begin{array}{l}\text { As pessoas aqui se acostumaram a uma sistemática de } \\
\text { trabalho coletivo e a gente tem até medo das } \\
\text { mudanças da Secretaria que possam acabar com este } \\
\text { trabalho. Sei lá ...um sistema diferente de contratar } \\
\text { professores, uma nova reorganização... }\end{array}$ \\
\hline
\end{tabular}




\begin{tabular}{|c|c|c|}
\hline \multicolumn{3}{|c|}{ DISCURSO 11 - CATEGORIAS, TEMAS E EXPRESSÕES CHAVE } \\
\hline CATEGORIA & TEMAS E SUB-TEMAS & EXPRESSÕES CHAVE \\
\hline \multirow[t]{3}{*}{$\begin{array}{l}\text { 1. CARACTERISTICAS } \\
\text { DE UMA BOA ESCOLA }\end{array}$} & 1.1. Estrutura e ambiente fisico de boa qualidade & $\begin{array}{l}\text { Esta é uma boa escola ...é bem estruturada, limpa, } \\
\text { bonita. Os espaços são bons e a gente fica contente de } \\
\text { trabalhar aqui. Produz mais, ensina melhor, os alunos } \\
\text { se saem melhor - isto não tem a ver com uma boa } \\
\text { escola? }\end{array}$ \\
\hline & $\begin{array}{l}\text { 1.2. Gestão escolar } \\
\text { 1.2.2. Adesão da comunidade escolar ao projeto } \\
\text { da escola (participa da sua implementação) } \\
\text { 1.2.3. Entrosamento entre os elementos da equipe }\end{array}$ & $\begin{array}{l}\text { A comunidade participa, se interessa pela escola, } \\
\text { contribui para que o nosso projeto seja posto em } \\
\text { prática. Dai dá para fazer um bom trabalho com os } \\
\text { alunos, com o apoio dos pais. } \\
\text { As pessoas aqui da escola são bem entrosadas - isto } \\
\text { facilita o trabalho para que a escola seja de boa } \\
\text { qualidade. }\end{array}$ \\
\hline & $\begin{array}{l}\text { 1.3. Qualidade de ensino } \\
\text { 1.3.1. diversificação das atividades de ensino e } \\
\text { aprendizagem e utilização de recursos didático- } \\
\text { pedagógicos }\end{array}$ & $\begin{array}{l}\text { Esta é uma boa escola, rica em materiais didáticos; a } \\
\text { gente tem acesso a este material, dá para fazer um } \\
\text { trabalho bom com ele. Também temos condições para } \\
\text { que os alunos realizam pesquisa na biblioteca, saiam } \\
\text { para projetos culturais.... }\end{array}$ \\
\hline
\end{tabular}




\begin{tabular}{|c|c|c|}
\hline \multicolumn{3}{|c|}{ DISCURSO 11 - CATEGORIAS, TEMAS E EXPRESSÕES CHAVE } \\
\hline CATEGORIA & \begin{tabular}{|l|} 
TEMAS E SUB-TEMAS \\
\end{tabular} & \begin{tabular}{|c|} 
EXPRESSÕES CHAVE \\
\end{tabular} \\
\hline \multirow[t]{4}{*}{$\begin{array}{l}\text { 2. CARACTERÍSTICAS } \\
\text { DE UMA ESCOLA } \\
\text { SAUDÁVEL }\end{array}$} & $\begin{array}{l}\text { 2.1. Gestão escolar } \\
2.1 \text {.1. Adesão da comunidade ao projeto da } \\
\text { escola (participa de sua implementação) }\end{array}$ & $\begin{array}{l}\text { Acho que o ponto forte da escola é a participação dos } \\
\text { pais... fica mais fácil fazer um bom trabalho, um bom } \\
\text { projeto, quando não se tem que brigar com a } \\
\text { comunidade...quando os pais colaboram, quando } \\
\text { respeitam a escola, quando a escola não é destruída } \\
\text { aos finais de semana.. }\end{array}$ \\
\hline & $\begin{array}{l}\text { 2.2. Qualidade do ensino } \\
\text { 2.2.1. Bons resultados de rendimento e } \\
\text { desempenho escolar }\end{array}$ & $\begin{array}{l}\text { Podemos melhorar ainda mais, mas a nossa escola tem } \\
\text { alcançado melhores resultados que as outras. As } \\
\text { pessoas de Carapicuiba respeitam os alunos que } \\
\text { estudaram no Fornasaro. }\end{array}$ \\
\hline & 2.2.2. Bom nível de participação dos alunos & $\begin{array}{l}\text { Os alunos são muito participativos. Eles sempre } \\
\text { questionam os trabalhos que a gente vai fazer } \\
\ldots \text { querem explicações, saber o porquê de tudo. Mas } \\
\text { depois são muito atentos, muito dedicados. Consigo } \\
\text { muito com eles. }\end{array}$ \\
\hline & $\begin{array}{l}\text { 2.3. Relação entre escola saudável e escola de } \\
\text { boa qualidade } \\
\text { 2.3.1. Toda escola saudável é uma boa escola } \\
\text { 2.3.2. Nem sempre uma boa escola é uma escola } \\
\text { saudável }\end{array}$ & $\begin{array}{l}\text { Estava querendo dizer que uma escola saudável é por } \\
\text { natureza uma boa escola. A escola não é um hospital... } \\
\text { é uma escola. E faz parte de ser saudável que ela faça } \\
\text { bem o que precisa fazer, o que é só ela que faz ... } \\
\text { Agora, o contrário disso pode não acontecer...já vi } \\
\text { escola que é considerada boa que não está nem aí com } \\
\text { a qualidade de vida dos alunos ..que não tem este } \\
\text { clima agradável daqui. }\end{array}$ \\
\hline
\end{tabular}




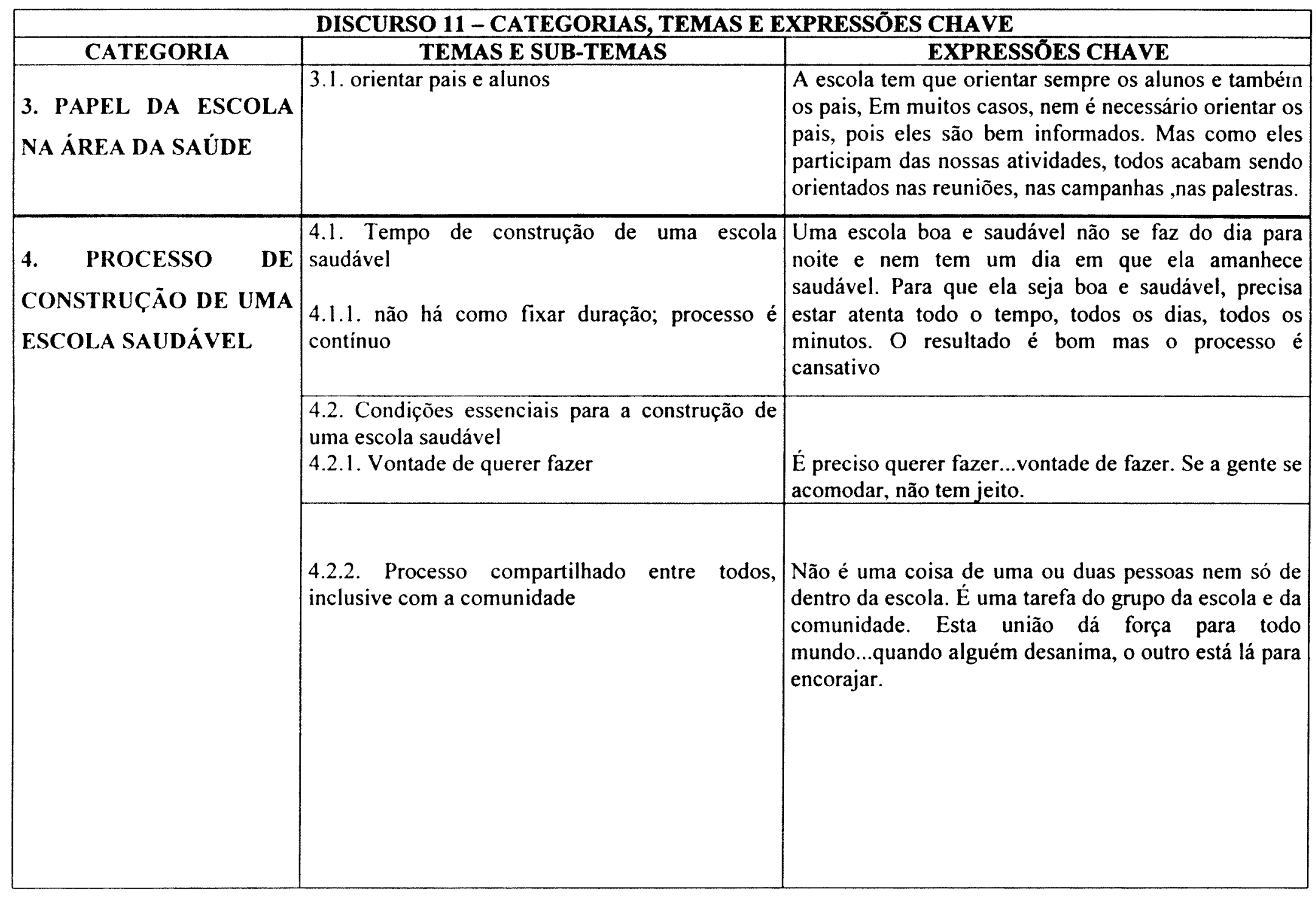




\begin{tabular}{|c|c|c|}
\hline \multicolumn{3}{|c|}{ DISCURSO 11 - CATEGORIAS, TEMAS E EXPRESSŌES CHAVE } \\
\hline CATEGORIA & TEMAS E SUB-TEMAS & EXPRESSŌES CHAVE \\
\hline $\begin{array}{l}\text { 4. PROCESSO DE } \\
\text { CONSTRUÇÃO DE UMA } \\
\text { ESCOLA SAUDÁ VEL }\end{array}$ & $\begin{array}{l}\text { 4.3. Contribuição pessoal } \\
\text { 4.3.1. Compromisso com a realização de um bom } \\
\text { trabalho em sala de aula }\end{array}$ & $\begin{array}{l}\text { Me entroso com o grupo, participo das atividades } \\
\text { coletivas, troco bastante com eles, mas acho que a } \\
\text { minha maior contribuição é o trabalho que faço em } \\
\text { sala de aula. Levo sério o meu trabalho, encaro o meu } \\
\text { aluno como uma pessoa, me empenho para saber o } \\
\text { que ele já sabe e fazer ele crescer... eles se valorizam } \\
\text { mais e viram gente grande, boa, saudável, que sabe o } \\
\text { que quer, que sabe fazer, que sabe conseguir as coisas. } \\
\text { Se todos os professores fizerem assim acho que é } \\
\text { muito. }\end{array}$ \\
\hline
\end{tabular}




\begin{tabular}{|c|c|c|}
\hline \multicolumn{3}{|c|}{ DISCURSO 12 - CATEGORIAS, TEMAS E EXPRESSÕES CHAVE } \\
\hline CATEGORIA & TEMAS E SUB-TEMAS & EXPRESSÕES CHAVE \\
\hline \multirow[t]{3}{*}{$\begin{array}{l}\text { 1. CARACTERÍSTICAS } \\
\text { DE UMA BOA ESCOLA }\end{array}$} & $\begin{array}{l}\text { 1.1. Estrutura e ambiente fisico de boa qualidade } \\
\text { (bom estado de conservação, limpeza, boas } \\
\text { instalações) }\end{array}$ & $\begin{array}{l}\text { Esta escola é boa , limpa, conservada, decente, tem } \\
\text { boas instalações ...não tem nada quebrado, nada fora } \\
\text { de lugar. Quando quebra, o conserto acontece logo } \\
\text {...as providências são tomadas logo. É uma escola que } \\
\text { tem muitos recursos materiais, uma escola } \\
\text { arrumadinha, onde tudo funciona. }\end{array}$ \\
\hline & $\begin{array}{l}\text { 1.2. Gestão escolar } \\
\text { 1.2.1. Projeto escolar claramente definido e } \\
\text { conhecido pela comunidade escolar }\end{array}$ & $\begin{array}{l}\text { A escola é boa ...prova disso é que tem um projeto que } \\
\text { ela divulga ... qui funciona tudo funciona ..todos têm } \\
\text { o seu dever e todos cumprem este dever. Aqui tem } \\
\text { regras claras ...os alunos, a escola, os pais, todos } \\
\text { sabem as regras. Os alunos que vêm de fora as vezes } \\
\text { têm um pouco de dificuldade para se adaptar. Mas } \\
\text { eles se acertam logo. }\end{array}$ \\
\hline & $\begin{array}{l}\text { 1.3. Qualidade de ensino } \\
\text { 1.3.1. bons resultados de rendimento e } \\
\text { desempenho escolar }\end{array}$ & $\begin{array}{l}\text { Julgo que a escola tem conseguido que os alunos } \\
\text { tenham um bom nivel ... que dominem } \\
\text { conhecimentos, que façam alguma coisa com estes } \\
\text { conhecimentos, que sejam participativos...Trabalho } \\
\text { aqui há } 15 \text { anos e sempre gostei da qualidade do } \\
\text { ensino aqui ...também por isto acho que é um lugar } \\
\text { bom de trabalhar. } \\
\text { Nesta escola não vejo ninguém assim fora ... assim } \\
\text { enrolando .ninguém que não esteja voltado para a } \\
\text { meta da escola que é a aula. a educação em si. o } \\
\text { traballo pedagogico com o aluno. Tudo deve ter como } \\
\text { objetivo o aluno e por isto é que eu acho que esta é } \\
\text { uma hroa escola. }\end{array}$ \\
\hline
\end{tabular}




\begin{tabular}{|l|l|l|}
\hline \multicolumn{1}{|c|}{ DISCURSO 12-CATEGORIAS, TEMAS E EXPRESSÓES CHAVE } \\
\hline $\begin{array}{l}\text { 1. CARACTERÍSTICAS } \\
\text { DE UMA BOA ESCOLA }\end{array}$ & $\begin{array}{l}\text { TEMAS E SUB-TEMAS } \\
\text { 1.3.3. a família dos professores e funcionários } \\
\text { confia na qualidade do trabalho da escola } \\
\text { (filhos, sobrinhos e netos estudam na escola }\end{array}$ & $\begin{array}{l}\text { EXPRESSÕES CHAVE } \\
\text { uma sala que não tenha um filho de uma pessoa que a } \\
\text { gente conheça. As pessoas confiam na escola ...só não } \\
\text { ponho aqui o meu filho, porque ele é pequenininho, } \\
\text { mas ainda vou por. }\end{array}$ \\
\hline \multirow{2}{*}{$\begin{array}{l}\text { 2. CARACTERÍSTICAS UMA ESCOLA } \\
\text { SAUDÁVEL }\end{array}$} & $\begin{array}{l}\text { 2.1. Ambientes e/ou espaços da escola } \\
\text { particularmente saudáveis } \\
\text { 2.1.1. refeitório }\end{array}$ & $\begin{array}{l}\text { O refeitório da escola dá de dez no das outras escolas } \\
\text { isto quando elas têm. A merenda não chega a ser } \\
\text { muito rica ou diversificada, mas tem boa qualidade. }\end{array}$ \\
& $\begin{array}{l}\text { No noturno, a merenda é um sucesso - .os alunos que } \\
\text { chegam do trabalho podem comer na escola, antes de } \\
\text { começar a aula. Para eles é uma maravilha ..uma sopa, } \\
\text { arroz doce, uma fruta. Aqui, os professores comem a } \\
\text { mesma comida que os alunos - e isto não acontece em } \\
\text { todas as escolas. } \\
\text { Os nossos banheiros são super-limpos- e es estou } \\
\text { falando dos banheiros dos alunos também. Temos } \\
\text { espelhos no banheiro e papel higiênico. Não é o } \\
\text { máximo? Não parece uma escola particular? Apenas } \\
\text { respeitamos os nossos alunos, eles se respeitam, } \\
\text { respeitam a escola e fazem o melhor por ela. }\end{array}$ \\
\hline
\end{tabular}




\begin{tabular}{|c|c|c|}
\hline \multicolumn{3}{|c|}{ DISCURSO 12 - CATEGORIAS, TEMAS E EXPRESSŌES CHAVE } \\
\hline CATEGORIA & TEMAS E SUB-TEMAS & EXPRESSŌES CHAVE \\
\hline \multirow[t]{4}{*}{$\begin{array}{l}\text { 2. CARACTERISTICAS } \\
\text { DE UMA ESCOLA } \\
\text { SAUDÁVEL }\end{array}$} & $\begin{array}{l}\text { 2.2.2. Funcionamento efetivo das instâncias de } \\
\text { democratização da escola (Conselho de Escola e } \\
\text { de Classe, Associação de Pais e Mestres e } \\
\text { Grêmio Estudantil) }\end{array}$ & $\begin{array}{l}\text { Um fator que contribui para que a escola seja saudável } \\
\text { e seja boa é que o Conselho de Escola funciona bem, } \\
\text { inclusive para discutir os resultados dos filhos na } \\
\text { escola. Olha que isto é raro nas escolas, pois os } \\
\text { Conselhos de Escola são muito fechados. }\end{array}$ \\
\hline & $\begin{array}{l}\text { 2.2. 3.Seriedade e profissionalismo dos } \\
\text { professores }\end{array}$ & $\begin{array}{l}\text { Acho que os professores respeitam muito os seus } \\
\text { alunos... não perdem a calma, não usam palavrões, } \\
\text { como a gente ouve dizer que acontece em outras } \\
\text { escolas. Nem todos são iguais, mas eu estou falando } \\
\text { da escola como um todos. }\end{array}$ \\
\hline & $\begin{array}{l}\text { 2.2. 4. Preocupação com a qualidade de vida das } \\
\text { pessoas que vivem na escola }\end{array}$ & $\begin{array}{l}\text { O grupo tem uma preocupação para que a gente viva } \\
\text { bem aqui dentro. Tenho amigas que trabalham em } \\
\text { outras escolas e elas têm problemas de drogas, de } \\
\text { violência ...é lógico que isto tem em todo lugar, mas } \\
\text { nós não temos nada que atrapalhe o trabalho da } \\
\text { escola. }\end{array}$ \\
\hline & $\begin{array}{l}\text { 2.2.5. Responsabilização dos alunos e } \\
\text { comunidade pela conservação da escola }\end{array}$ & $\begin{array}{l}\text { Nós temos o hábito de fazer que os alunos e a } \\
\text { comunidade sejam responsáveis pela conservação da } \\
\text { escola. A escola é de todos - e isto vale para tomar } \\
\text { conta da escola. Não vejo como uma escola pode ser } \\
\text { boa ou ser saudável, não vejo como formar bons } \\
\text { cidadãos se as crianças e as familias não são chamadas } \\
\text { à responsabilidade, com bons modos, com educação, } \\
\text { com transparência. Não é sobrecarregar os pais, mas } \\
\text { fazer com que assumam o que tem de ser assumido } \\
\text { por eles. }\end{array}$ \\
\hline
\end{tabular}




\begin{tabular}{|c|c|c|}
\hline \multicolumn{3}{|c|}{ DISCURSO 12 - CATEGORIAS, TEMAS E EXPRESSÕES CHAVE } \\
\hline CATEGORIA & TEMAS E SUB-TEMAS & EXPRESSŌES CHAVE \\
\hline $\begin{array}{l}\text { 2. CARACTERISTICAS } \\
\text { DE UMA ESCOLA } \\
\text { SAUDÁVEL }\end{array}$ & 2.3. Características dos alunos & $\begin{array}{l}\text { Os nossos alunos contribuem muito para que a escola } \\
\text { seja boa e saudável. Não agem com violência, não } \\
\text { usam palavrões - os alunos diferentes que chegam de } \\
\text { fora ou seguem as regras daqui ou querem ir para } \\
\text { escolas mais desorganizadas. }\end{array}$ \\
\hline \multirow[t]{4}{*}{$\begin{array}{l}\text { 3. PAPEL DA ESCOLA } \\
\text { NA ÁREA DA SAÚDE }\end{array}$} & $\begin{array}{l}\text { 3.1. promoção da saúde pela articulação da teoria } \\
\text { com a prática }\end{array}$ & $\begin{array}{l}\text { Acho que a escola tenta promover a saúde dos } \\
\text { alunos... trabalha conteúdos e oferece oportunidades } \\
\text { para o aluno sinta, na prática, o que significa um } \\
\text { ambiente saudável, uma vida saudável. }\end{array}$ \\
\hline & $\begin{array}{l}\text { 3.2. transmissão de conhecimentos e de } \\
\text { referências no campo da saúde }\end{array}$ & $\begin{array}{l}\text { Na sala de aula nós precisamos transmitir } \\
\text { conhecimentos importantes de saúde. Em Ciências, } \\
\text { por exemplo, os alunos estudam doenças, como se } \\
\text { prevenir delas...alimentação, higiene, doenças } \\
\text { sexualmente transmissíveis. Em Matemática não dá } \\
\text { para trabalhar saúde ...ah...ia me esquecendo: na } 8^{\circ} \\
\text { série trabalhei com taxa de mortalidade, indices de } \\
\text { doenças, gráficos ...estas coisas. Não dá para incluir } \\
\text { tudo, mas dá para trabalhar com dados sobre nutrição, } \\
\text { oferta de alimentos. }\end{array}$ \\
\hline & 3.3. orientação de alunos & $\begin{array}{l}\text { Antes de ser professora de Matemática, sou educadora } \\
\text { e quando aparece um problema na sala, eu paro para } \\
\text { discutir este problema. Se eu tiver uma aluna com } \\
\text { problema e ela vem a mim, eu não vou me negar } \\
\text {...problema de higiene, de sexualidade ...vou } \\
\text { conversar com ela, vou orientar no que puder. }\end{array}$ \\
\hline & $\begin{array}{l}\text { 3.4. encaminhamento dos alunos aos serviços de } \\
\text { saúde }\end{array}$ & $\begin{array}{l}\text { A escola encaminha os alunos que precisam de } \\
\text { atendimento aos serviços locais ... informamos os pais } \\
\text { sobre as providências necessárias, os endereços } \\
\text {...depois, verificamos se os alunos foram atendidos. }\end{array}$ \\
\hline
\end{tabular}




\begin{tabular}{|c|c|c|}
\hline \multicolumn{3}{|c|}{ DISCURSO 12 - CATEGORIAS, TEMAS E EXPRESSÕES CHAVE } \\
\hline CATEGORIA & TEMAS E SUB-TEMAS & EXPRESSÕ̃ES CHAVE \\
\hline \multirow[t]{3}{*}{$\begin{array}{l}\text { 4. PROCESSO DE } \\
\text { CONSTRUÇÃO DE UMA } \\
\text { ESCOLA SAUDÁVEL }\end{array}$} & $\begin{array}{l}\text { 4.1. Tempo de construção de uma escola } \\
\text { saudável } \\
\text { 4.1.1. Não há como fixar um tempo; processo é } \\
\text { contínuo }\end{array}$ & $\begin{array}{l}\text { Não há limite de tempo para a escola se tornar } \\
\text { saudável ...isto é diário ...a cada dia a escola tem que } \\
\text { tomar cuidado para não deixar de ser saudável. A } \\
\text { escola não é saudável ...ela está saudável... se a escola } \\
\text { tomar atitudes erradas, ela pode deixar de ser } \\
\text { saudável. A escola é formada por pessoas e ela vai ser } \\
\text { saudável dependendo se as pessoas que formam ela } \\
\text { estão agindo neste objetivo, Por exemplo, se mudar a } \\
\text { direção, se o diretor não tem mais este objetivo, se os } \\
\text { professores não colaborarem ... uma escola que é } \\
\text { considerada saudável, no outro ano pode deixar de ser } \\
\text { saudável. }\end{array}$ \\
\hline & $\begin{array}{l}\text { 4.2. Condições essenciais para a construção de } \\
\text { uma escola saudável } \\
\text { 4.2.1. Vontade de querer fazer } \\
\text { 4.2.2. Processo compartilhado entre todos, } \\
\text { inclusive com a comunidade } \\
\text { 4.2.3. Estimulação e cobrança constante }\end{array}$ & $\begin{array}{l}\text { Se não houver uma vontade coletiva, a escola fica } \\
\text { patinando e se perde } \\
\text { Para transformar a escola, todos precisam se unir. } \\
\text { Tem que ter alguém ou um grupo para estimular } \\
\text { sempre. mas todos têm que participar, inclusive os } \\
\text { pais e alunos. } \\
\text { Eu disse que para a escola ser saudável precisa de } \\
\text { alguém para estimular sempre...precisa também cobrar } \\
\text { sempre, na boa, com respeito. Mas cobrar. }\end{array}$ \\
\hline & 4.2.4. Trabalho centrado no aluno & $\begin{array}{l}\text { Vou repetir o que já disse - a escola tem que estar } \\
\text { voltada para o aluno ...tem que dialogar sempre com } \\
\text { ele ... se a gente não manter um diálogo saudável com } \\
\text { os alunos, nada vai ser saudável. }\end{array}$ \\
\hline
\end{tabular}




\begin{tabular}{|l|l|l|}
\hline \multicolumn{2}{|c|}{ DISCURSO 12-CATEGORIAS, TEMAS E EXPRESSÕES CHAVE } \\
\hline \multicolumn{1}{|c|}{ CATEGORIA } & \multicolumn{1}{|c|}{ TEMAS E SUB-TEMAS } & \multicolumn{1}{|c|}{ EXPRESSÕES CHAVE } \\
\hline $\begin{array}{l}\text { 4. PROCESSO DE } \\
\text { ESCOLA SAUDÁVEL }\end{array}$ & $\begin{array}{l}\text { 4.3.1. ênfase constante no trabalho centrado do } \\
\text { aluno e na resolução de seus problemas, com } \\
\text { participação, envolvimento e responsabilização } \\
\text { dos pais }\end{array}$ & $\begin{array}{l}\text { Trabalho sempre para o aluno. Eles não acham minha } \\
\text { matéria fácil e eu me esforço para que eles possam } \\
\text { perder o medo, interessar-se pelas aplicações da } \\
\text { Matemática e aprenderem o que eu ensino. Quando } \\
\text { alguma coisa dá errado, falo com a coordenação, } \\
\text { converso com os pais. Acho que colaboro para que o } \\
\text { aluno fique na escola, seja bem sucedido - e eu não } \\
\text { entendo que alguém possa ser saudável se é expulso } \\
\text { da escola sem acabar o seu curso. }\end{array}$ \\
\hline
\end{tabular}




\section{Anexo 8}

Idéias centrais $e$ Expressões-chave 


\begin{tabular}{|c|c|}
\hline \multicolumn{2}{|r|}{ CARACTERISTICAS DE UMA BOA ESCOLA } \\
\hline IDÉIAS CENTRAIS & EXPRESSÕES-CHAVE - BOA ESCOLA \\
\hline $\begin{array}{l}\text { 1. Boa escola é aquela que tem } \\
\text { uma boa estrutura fisica, é } \\
\text { espaçosa, arrumada e tem } \\
\text { muito verde } \\
\text { Ou ... não dá para estudar numa } \\
\text { lata de lixo! }\end{array}$ & $\begin{array}{l}\text { D.1. "... posição geográfica dela é muito boa e é aquele silêncio, aquela paz. Além disto, ela tem muito } \\
\text { espaço... } \\
\text { D.2. "é uma escola limpa, é uma escola bonita" } \\
\text { D.4. "é óbvio que uma boa escola precisa ser limpa, ter equipamentos em ordem, funcionar } \\
\text { adequadamente ...ser agradável aos olhos, impressionar bem os alunos e a comunidade. É isto que } \\
\text { acontece com o Fornasaro" } \\
\text { D.6. "é uma escola limpa, com uma boa estrutura física e ótimas instalações" } \\
\text { D.7. "a escola oferece um ambiente limpo. decente para as crianças, o ambiente é muito bom. Não dá para } \\
\text { estudar dentro de uma lata de lixo" } \\
\text { D.8. "é muito verde, muita flor, muita ordem, muita limpeza..." } \\
\text { D.9. "a estrutura da escola é boa, o prédio é excelente, tudo é muito limpo e conservado } \\
\text { D.10. "...é limpa. bem construida, arejada, arborizada. Dá gosto de andar por aqui ...ela é esteticamente } \\
\text { bonita" } \\
\text { D.12. "...é boa, limpa. conservada, decente, tem boas instalações ...não tem nada quebrado, nada fora de } \\
\text { lugar. E uma escola que tem muitos recursos materiais, uma escola arrumadinha, onde tudo funciona" }\end{array}$ \\
\hline $\begin{array}{l}\text { 2. Boa escola é aquela que foi } \\
\text { criada pela comunidade, tem } \\
\text { uma certa tradição de trabalho } \\
\text { e um tempo considerável de } \\
\text { funcionamento. }\end{array}$ & $\begin{array}{l}\text { D.2. "esta escola já tem este trabalho há algum tempo, enquanto que outras estão começando este } \\
\text { trabalho. Esta está na frente, porque este trabalho já vem sendo feito há mais tempo, desde quando a } \\
\text { escola foi fundada pela colónia italiana" } \\
\text { D.4. " tem } 25 \text { anos, foi fundada por italianos que trabalhavam num tecelagem aqui perto" } \\
\text { D.7. Esta escola é de descendentes de um grupo de italianos ...mesmo que a clientela tenha variado, eles } \\
\text { têm conseguido manter essa coisa do início. É uma escola antiga, que já tem uma história e isto ajuda } \\
\text { muito" } \\
\text { D.8. Esta é uma escola antiga, com um projeto que foi se acertando aos poucos. Há pessoas que trabalham } \\
\text { juntas há mais e } 15 \text { anos ... ninguém está só de passagem pela escola, só até arrumar uma coisa melhor. } \\
\text { Esta história da escola conta muito para que ela vá se aperfeiçoando cada vez mais"coisa8. }\end{array}$ \\
\hline
\end{tabular}




\begin{tabular}{|c|c|}
\hline \multicolumn{2}{|r|}{ CARACTERÍSTICAS DE UMA BOA ESCOLA } \\
\hline IDÉIAS CENTRAIS & EXPRESSÕES-CHAVE - BOA ESCOLA \\
\hline $\begin{array}{l}\text { 3. Boa escola é aquela que tem } \\
\text { um projeto claramente } \\
\text { definido, coletivo, no qual se } \\
\text { explicita claramente o que, } \\
\text { como e quando fazer. }\end{array}$ & $\begin{array}{l}\text { D.I. "...ela trabalha as pessoas que vêm para cá para que elas se inteirem do projeto desta escola. E eu } \\
\text { confesso que não sei exatamente dizer quais são os trabalhos que eles fazem sistematicamente para que } \\
\text { todos consigam conhecer este projeto. } \\
\text { D.2. "ela está na frente porque tem um projeto que é conhecido por todos" } \\
\text { D.3. "o grupo aqui sabe o que quer, o que vai fazer, como vai fazer ...os pais também sabem de tudo isto" } \\
\text { D.4. "a escola é boa porque a gente sabe o que quer. Não digo que não poderiamos querer outra coisa } \\
\text { melhor, mas a comunidade conhece e aprova o nosso projeto. Não dá para improvisar em educação . tem } \\
\text { que planejar, tem que ter objetivo, tem que chegar a algum lugar, tem que corrigir rumos, tem que rever. } \\
\text { tem que fazer de novo". } \\
\text { D.5. "no planejamento do início do ano nós sempre discutimos qual vai ser o lema da escola durante o } \\
\text { ano. qual será o nosso projeto, o que vamos fazer, como vamos fazer ...as nossas prioridades" } \\
\text { D.8. "a escola tem um projeto que todos conhecem, inclusive a comunidade. Nós sabemos o que } \\
\text { queremos." } \\
\text { D.12. "a escola é boa ...prova disso é que tem um projeto que ela divulga ...aqui funciona tudo funciona } \\
\text {.todos têm o seu dever e todos cumprem este dever. Aqui tem regras claras ...os alunos, a escola, os pais, } \\
\text { todos sabem as regras" }\end{array}$ \\
\hline $\begin{array}{l}\text { 4. Boa escola é aquela cujo } \\
\text { projeto é conhecido e aprovado } \\
\text { pela commintade, que participa } \\
\text { em todos os momentos de sua } \\
\text { implementação }\end{array}$ & $\begin{array}{l}\text { D.1. "não sei como eles fazem para que a comunidade compre o projeto da escola e participe da sua } \\
\text { implementação, mas eles conseguem isso (...) O pessoal que chega assume os valores dos que já estavam } \\
\text { açui c compram o projelo da escola". } \\
\text { D.3. "Confio no projeto desta escola...confio também na comunidade que tem vontade e força para que } \\
\text { este projeto se realize e sempre se junta com a escola para o melhor. Escola e comunidade aqui se } \\
\text { entendem bem - e esta é a regra! } \\
\text { D.4. "a comunidade participa muito - ela é nossa parceira de todas as horas. A escola tem um excelente } \\
\text { relacionamento com a comunidade. É raro o final de semana que a escola não está aberta ...a comunidade } \\
\text { se responsabiliza por tudo e nunca tivemos nenhum problema. Como moro aqui perto, inclusive muitos } \\
\text { pais de alunos ficaram meus amigos pessoais. A escola conta com eles e eles com a escola - a escola é } \\
\text { nossa...nós somos a comunidade" } \\
\text { D.5. "a comunidade compra o projeto da escola ...ela participa muito. Ela é parceira da escola, os pais } \\
\text { colaboram em tudo que é necessário e valorizam o nosso trabalho. Nossos professores têm liberdade para } \\
\text { convocar os pais e conversar com eles, no horário que for possivel. Não dá para fazer um bom trabalho se } \\
\text { a comunidade não está aqui dentro e acho que é este o nosso maior trunfo" }\end{array}$ \\
\hline
\end{tabular}




\begin{tabular}{|c|c|}
\hline \multicolumn{2}{|r|}{ CARACTERÍSTICAS DE UMA BOA ESCOLA } \\
\hline IDÉLAS CENTRAIS & EXPRESSÕES-CHAVE - BOA ESCOLA \\
\hline $\begin{array}{l}\text { 4. Boa escola é aquela cujo } \\
\text { projeto é conhecido e aprovado } \\
\text { pela comunidade, que participa } \\
\text { em todas as fases de sua } \\
\text { implementação }\end{array}$ & 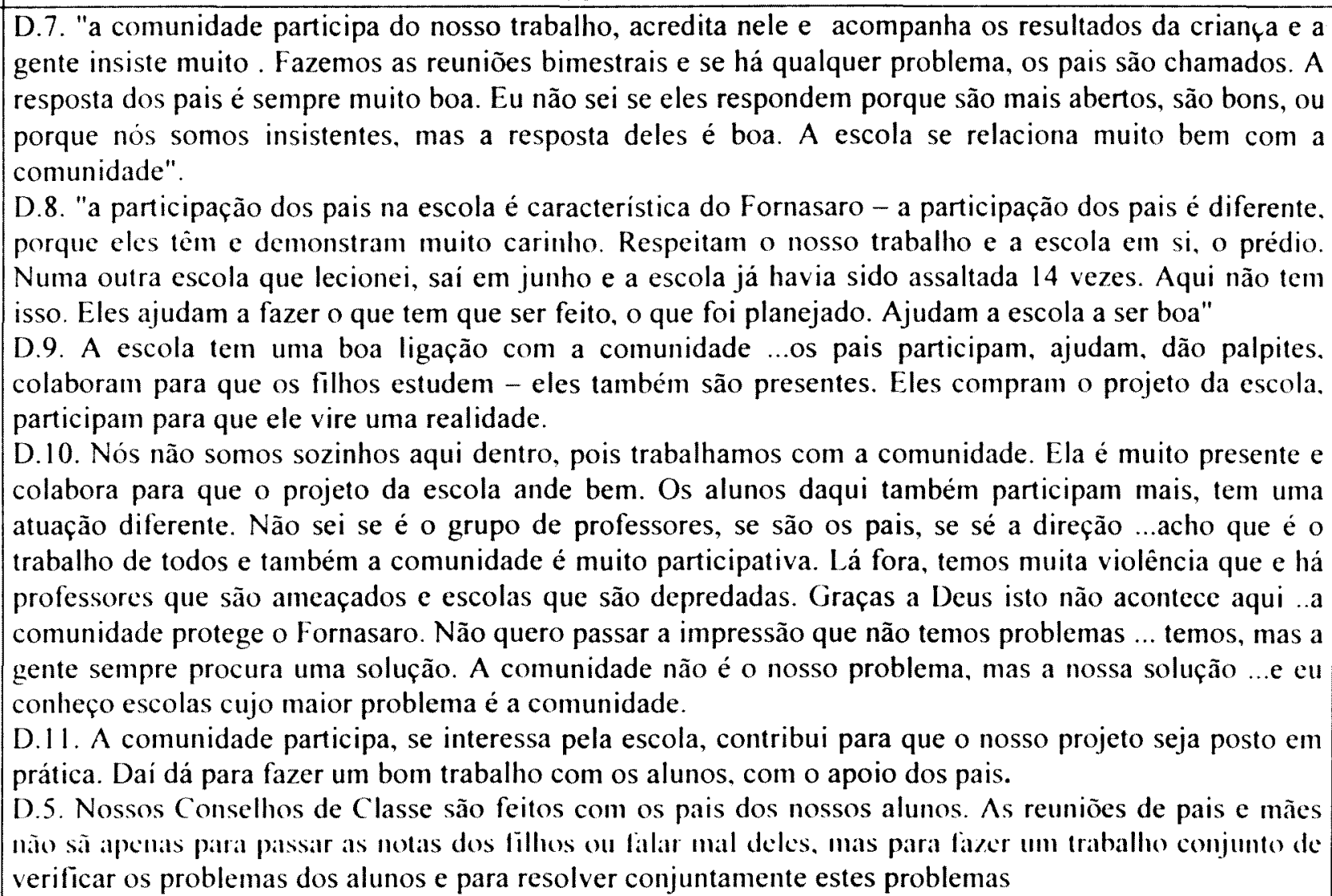 \\
\hline
\end{tabular}




\begin{tabular}{|c|c|}
\hline \multicolumn{2}{|r|}{ CARACTERISTICAS DE UMA BOA ESCOLA } \\
\hline IDEIAS CENTRAIS & EXPRESSŌES-CHAVE \\
\hline $\begin{array}{l}\text { 5. Boa escola é aquela que conta } \\
\text { com uma direção presente, } \\
\text { atuante, competente e que } \\
\text { consegue elevar a auto-estima e a } \\
\text { participação dos professores }\end{array}$ & $\begin{array}{l}\text { D.5. A direção é sempre muito presente. Fica o tempo todo na escola e há direção em todos os } \\
\text { periodos em que a escola funciona. A diretora e os vice sabem o que têm que fazer e fazem. } \\
\text { Elas são muito entrosadas entre elas e isto ajuda muito.. } \\
\text { D.6. "esta é uma escola que tem direção e isto em dois sentidos: a diretora vive aqui e sabe qual } \\
\text { é o seu papel - faz este papel muito bem. } \\
\text { D.8. "esta é uma ótima escola, porque aqui tudo funciona, principalmente a direção e o apoio } \\
\text { pedagógico. Elas estão sempre aqui, a qualquer hora e isto facilita o nosso trabalho. A direção é } \\
\text { sempre pronta, muito presente, muito dedicada e competente. O mesmo eu digo da } \\
\text { coordenadora. } \\
\text { D.9. a atuação da direção contribui muito para que a escola seja boa. A diretora está sempre } \\
\text { aqui, ela é séria, respeita e é respeitada pelas pessoas ... não perde tempo para resolver o que } \\
\text { tem que ser resolvido. } \\
\text { D.2. A gente vê que esta é uma boa escola pela constante preocupação da diretora em atacar os } \\
\text { vários problemas que a escola vai apresentando } \\
\text { D.3. A direção da escola estimula os professores e faz a escola andar (...) ela sempre eleva a } \\
\text { auto-estima dos professores. Na educação, as pessoas consideram o eventual como um tapa- } \\
\text { buraco. E aqui eu não sou um tapa-buraco e não sou considerado um tapa-buraco por ninguém. } \\
\text { Eu tenho um projeto. Quando eu entro numa sala de aula, os alunos já me conhecem. Já sabem o } \\
\text { que nós vamos trabalhar. Eles não ficam "olha, lá vem aquele chato". De forma alguma.... }\end{array}$ \\
\hline $\begin{array}{l}\text { 6. Boa escola é aquela que conta } \\
\text { com uma equipe bem entrosada, } \\
\text { séria, interessada em fazer um } \\
\text { bom trabalho e onde há } \\
\text { coleguismo. }\end{array}$ & $\begin{array}{l}\text { D.3. Não existe nas outras escolas o mesmo interesse que existe aqui ...tenho sempre a } \\
\text { impressão de que a maioria quer que esta escola seja cada vez melhor } \\
\text { D.4. Acho que a equipe é muito interessada ...sempre tem exceções, mas os professores que não } \\
\text { querem nada com nada acabam saindo da escola porque o grupo pressiona para que todos } \\
\text { trabalhem bem. } \\
\text { D.3. Eu noto que não existe nas outras escolas uma integração entre as pessoas, como existe } \\
\text { aqui. Ontem fui a uma escola que é bem avaliada em Cotia ...e eu não consegui perceber que as } \\
\text { pessoas estavam integradas.. eu não me senti bem lá e desisti logo. } \\
\text { D.6. Os professores aqui estão bem entrosados...às vezes, tem até um clima dos professores } \\
\text { mais antigos torcerem o nariz para os que acabam de chegar. Acho que o ingresso dos } \\
\text { professores que passaram no último concurso vai resolver isto e o entrosamento contribui para } \\
\text { que a escola melhore o seu trabalho. }\end{array}$ \\
\hline
\end{tabular}




\begin{tabular}{|c|c|}
\hline \multicolumn{2}{|r|}{ CARACTERISTICAS DE UMA BOA ESCOLA } \\
\hline IDÉIAS CENTRAIS & EXPRESSÕES-CHAVE \\
\hline $\begin{array}{l}\text { 6. Boa escola é aquela que conta } \\
\text { com uma equipe bem entrosada, } \\
\text { séria, interessada em fazer um } \\
\text { bom trabalho e onde há } \\
\text { coleguismo. }\end{array}$ & $\begin{array}{l}\text { D.8. A escola é boa porque há muito coleguismo aqui...as pessoas estão bem entrosadas, se } \\
\text { respeitam muito. Quando é necessário, um ajuda o outro, até profissionalmente. Nós trocamos } \\
\text { idéias, contamos como foi trabalhar desta ou daquela maneira com uma série ... } \\
\text { D.9. Esta escola me marcou muito. A diferença é da água para o vinho. Nas outras escolas, falta } \\
\text { diálogo, falta amizade, falta coleguismo, falta organização. Aqui, as pessoas estão bem } \\
\text { entrosadas e isto acontece fora da aula ...quer dizer, as pessoas não se entrosam apenas para } \\
\text { melhorar a aula. mas também para deixar o clima daqui legal. A comunidade gosta e valoriza a } \\
\text { escola. } \\
\text { D.11 As pessoas aqui da escola são bem entrosadas - isto facilita o trabalho para que a escola } \\
\text { seja de boa qualidade. } \\
\text { D.12. A equipe daqui é séria. Tem gente que acha que a gente exagera. Sempre tem quem é } \\
\text { diferente, mas todos agem com muito profissionalismo. Eles sabem fazer o que fazem, gostam } \\
\text { do que fazem e quem não gosta e quer enrolar dá um jeito de ir para outra escola mais folgada } \\
\text { Tem alunos nossos que vão embora para o Maria Alice, perto daqui. Uma aluna foi embora e } \\
\text { estava de volta, no outro dia. Eu disse, Viviane, já voltou? Ela disse: "Professora, naquela } \\
\text { escola o que menos tem é aula e nem o banheiro tem porta. Então eu só posso considerar que } \\
\text { esta é muito mais escola, no sentido de que as pessoas agem como verdadeiros profissionais. }\end{array}$ \\
\hline $\begin{array}{l}\text { 7. Boa escola é aquela que conta } \\
\text { com bons professores }\end{array}$ & $\begin{array}{l}\text { D.7. A escola é boa também porque tem bons professores. Eles não enxergam a escola como } \\
\text { um emprego, mas também não acham que isto é sacerdócio. Trabalhamos sério e merecemos } \\
\text { nosso salário. Esta escola é assim. Somos respeitados pelos pais - nem todas as escolas são. }\end{array}$ \\
\hline 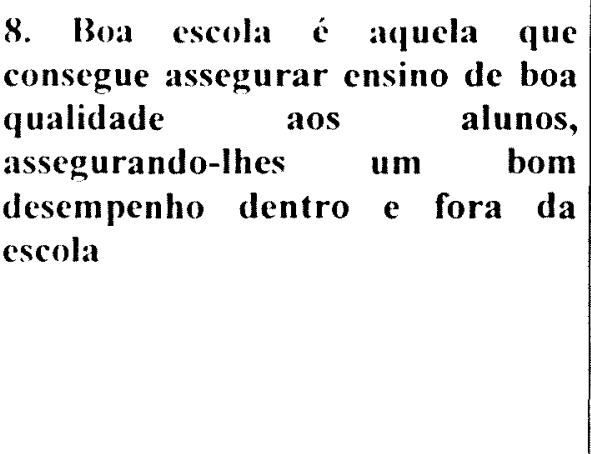 & $\begin{array}{l}\text { D.2. A escola a boa porque tem obtido bons resultados e mesmo que estes não scjam } \\
\text { excelentes. a gente sempre está melhorando. Muitos alunos daqui têm se saido bem aqui e fora } \\
\text { daqui, porque são bem preparados, aprenderam a argumentar. a consultar jornais, a respeitar os } \\
\text { outros. } \\
\text { D.5. Os meus fillhos estudaram aqui e aprenderam a pesquisar, a investigar, a questionar, a } \\
\text { participar...enfim, não tenho nada a reclamar da maneira como eles foram formados aqui } \\
\text { D.8. nossos alunos saem daqui em melhor condição do que muitos de outras escolas. } \\
\text { D.10. Não dá para falar em boa escola se a gente não fala que os alunos aprendem... temos } \\
\text { também dificuldades, os alunos não são iguais, as classes também, mas os alunos têm um bom } \\
\text { rendimento... acho que a escola está acertando no que faz. }\end{array}$ \\
\hline
\end{tabular}




\begin{tabular}{|c|c|}
\hline \multicolumn{2}{|r|}{ CARACTERÍSTICAS DE UMA BOA ESCOLA } \\
\hline IDÉIAS CENTRAIS & $\begin{array}{l}\text { EXPRESSÕES-CHAVE } \\
\end{array}$ \\
\hline $\begin{array}{l}\text { 8. Boa escola é aquela que } \\
\text { consegue assegurar ensino de boa } \\
\text { qualidade aos ranos, } \\
\text { assegurando-thes um bom } \\
\text { desempenho dentro e fora da } \\
\text { escola }\end{array}$ & $\begin{array}{l}\text { D.12. Julgo que a escola tem conseguido que os alunos tenham um bom nível ... que dominem } \\
\text { conhecimentos, que façam alguma coisa com estes conhecimentos, que sejam } \\
\text { participativos... Trabalho aqui há } 15 \text { anos e sempre gostei da qualidade do ensino aqui ... } \\
\text { D.2 Esta escola é uma boa escola e a gente vê pela preocupação dos professores em fazer com } \\
\text { que os alunos possam aprender e tenham bons resultados na escola...eles fazem muito esforço } \\
\text { para que o aluno permaneça na escola e isto faz muita diferença para os alunos e para a escola. }\end{array}$ \\
\hline $\begin{array}{l}\text { 9. Boa escola é aquela que otimiza } \\
\text { o tempo de permanência do aluno } \\
\text { na escola e se empenha para evitar } \\
\text { a evasão escolar }\end{array}$ & 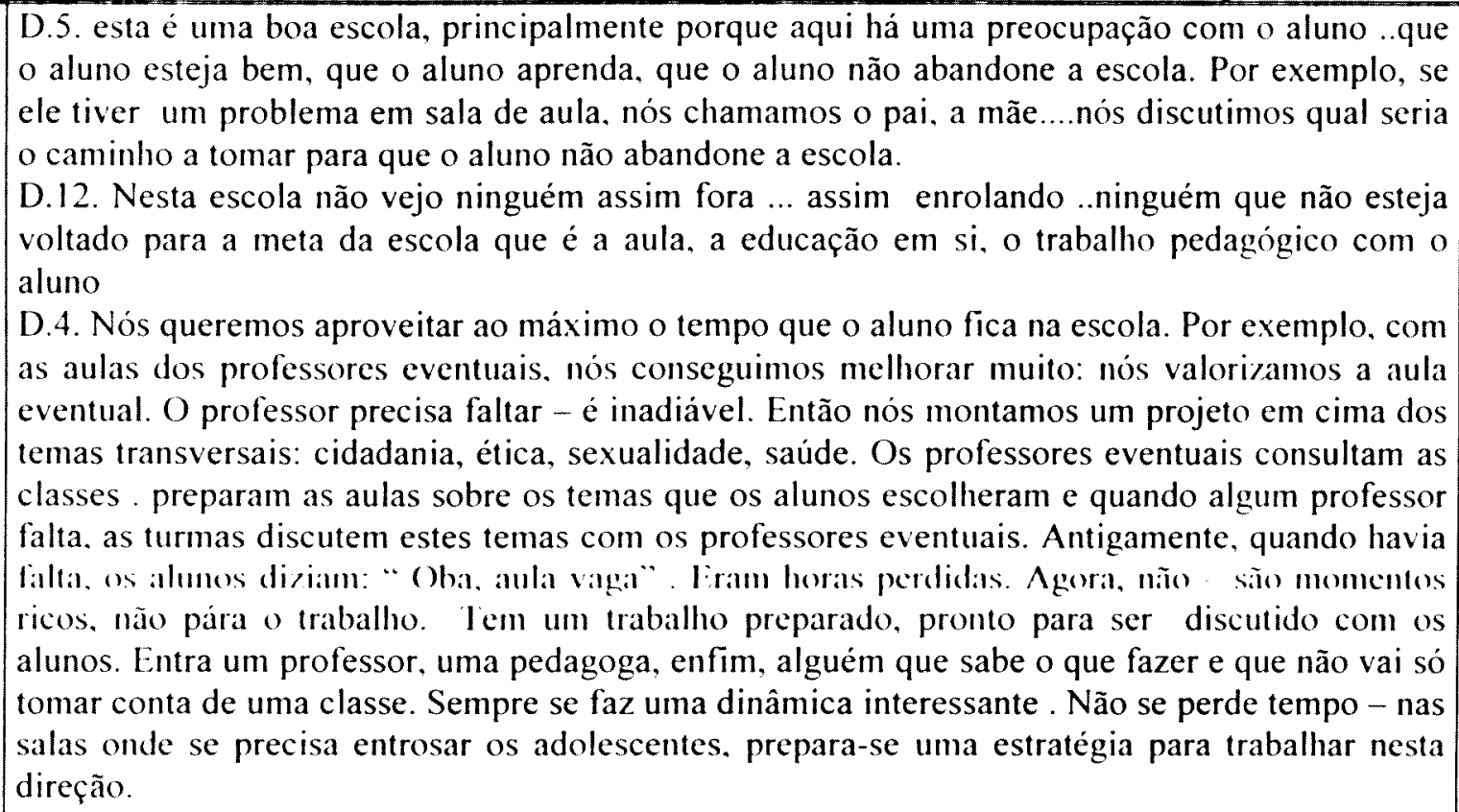 \\
\hline
\end{tabular}




\begin{tabular}{|c|c|}
\hline \multicolumn{2}{|r|}{ CARACTERÍSTICAS DE UMA BOA ESCOLA } \\
\hline IDÉIAS CENTRAIS & EXPRESSÕES-CHAVE \\
\hline $\begin{array}{l}\text { 9. Boa escola é aquela que otimiza } \\
\text { o tempo de permanência do aluno } \\
\text { na escola e se empenha para evitar } \\
\text { a evasão escolar }\end{array}$ & $\begin{array}{l}\text { D.5. Esta escola é boa porque valoriza o tempo que o aluno fica na escola ...esta escola é taxada } \\
\text { assim- todo mundo teve férias e nós tivemos recuperação. Tinha greve e a gente repunha aula } \\
\text { minuto a minuto. A direção entrava na classe e não tinha } 70 \% \text { dos alunos - era outro dia de } \\
\text { reposição. Nisso. esta escola sempre foi linha dura. Aqui não se junta aula - e isto acontece } \\
\text { muito por ai. No noturno, é a mesma seriedade - não tem esta coisa de não ter aula, do aluno } \\
\text { voltar cedo para casa ...os professores eventuais fazem um bom trabalho e acho que isto mostra } \\
\text { que não estamos brincando aqui. Aconselhei amigas minhas a tirarem os fillos de escola } \\
\text { particular que é boa e trazer para cá que é melhor. Nós temos preocupação com o aluno que } \\
\text { cabula, pois queremos o aluno dentro da sala de aula. }\end{array}$ \\
\hline $\begin{array}{l}\text { 10. Boa escola é aquela que diver- } \\
\text { sifica as atividades de ensino e } \\
\text { aprendizagem, utiliza recursos } \\
\text { didático-pedagógicos variados em } \\
\text { sala de aula, realiza atividades } \\
\text { culturais e conta com uma boa } \\
\text { biblioteca, bem utilizada pelos } \\
\text { alunos. }\end{array}$ & 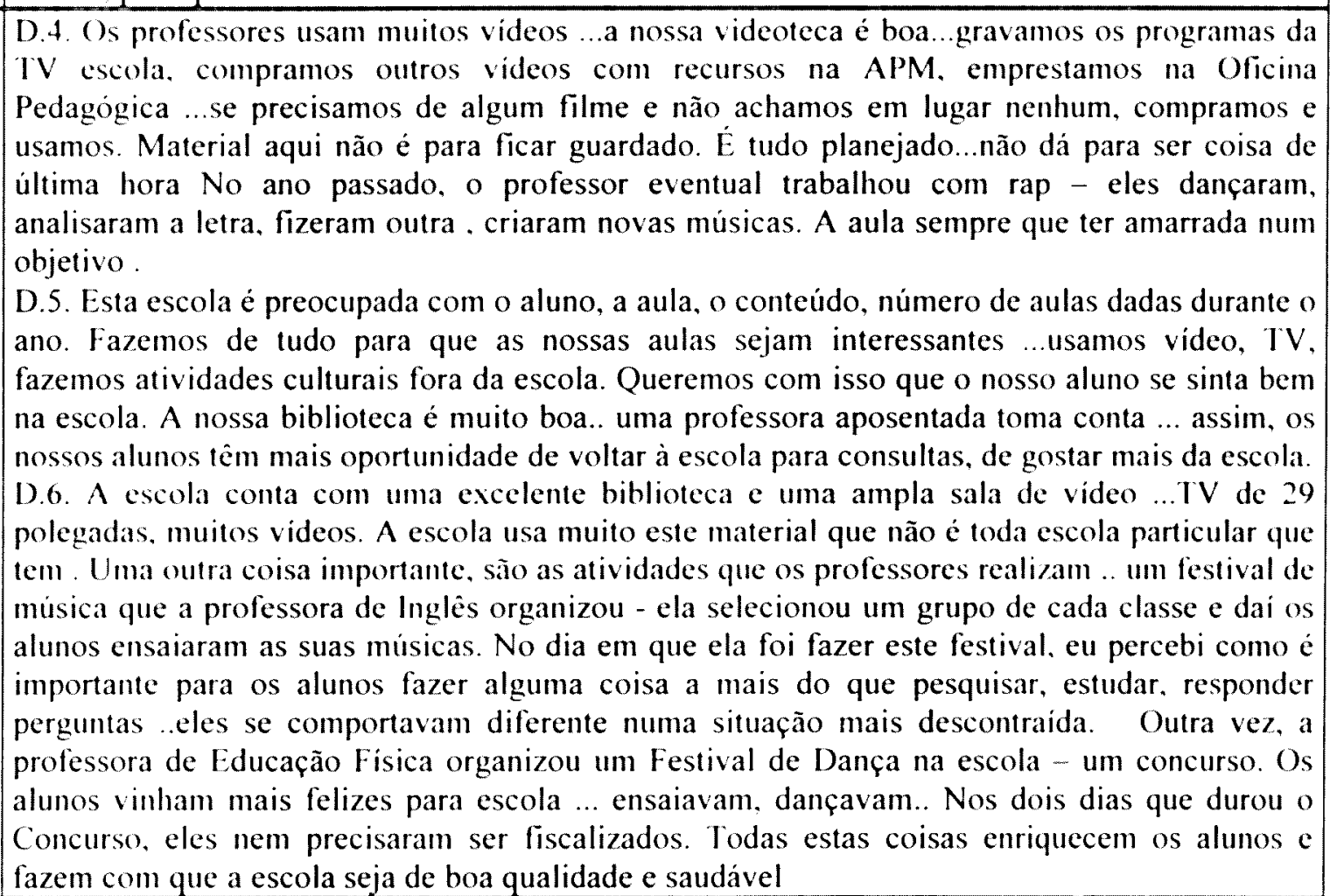 \\
\hline
\end{tabular}




\begin{tabular}{|c|c|}
\hline \multicolumn{2}{|r|}{ CARACTERÍSTICAS DE UMA BOA ESCOLA } \\
\hline IDÉIAS CENTRAIS & $\begin{array}{l}\text { EXPRESSÕES-CHAVE } \\
\end{array}$ \\
\hline $\begin{array}{l}\text { 11. Boa escola é aquela na qual as } \\
\text { horas de trabalho coletivo são } \\
\text { utilizadas para um autêntica } \\
\text { capacitação dos professores, } \\
\text { possibilitando troca de } \\
\text { experiências entre eles }\end{array}$ & $\begin{array}{l}\text { D.4. As nossas Horas de Trabalho Coletivo viram horas de capacitação, pois as pessoas trocam } \\
\text { experiências, aprendem uns com os outros. Assim, muita gente perde o medo de tentar fazer } \\
\text { alguma coisa boa que já deu certo, elas crescem profissionalmente, as aulas ficam mais ricas e } \\
\text { todos ganhamos com isso. Até os professores eventuais participam das HTPCs e olhe que eles } \\
\text { não recebem por este horário de planejamento. Eles contam para os professores o que os seus } \\
\text { alunos estão produzindo nas aulas em que eles faltaram, dão informações sobre aspectos da } \\
\text { personalidade dos alunos que os professores nem conhecem. } \\
\text { D.8. Iu já falci um pouco disso, mas acho que vale a pena reforçar. Em muitas escolas, os } \\
\text { professores ficam inventando o que fazer nas HTPCs. Nós aprendemos a usar bem este tempo, } \\
\text { trocando idéias sobre o que cada um fez na sua sala e deu certo, combinando o que cada um vai } \\
\text { dar em sua disciplina, conversando sobre os alunos que estão com problemas de aprender ou } \\
\text { mesmo de disciplina. Acho que a gente vai se aperfeiçoando e as aulas é que ganham ...os } \\
\text { alunos, na verdade. }\end{array}$ \\
\hline $\begin{array}{l}\text { 12. Boa escola é aquela que conta } \\
\text { com a confiança de seus alunos e } \\
\text { funcionários que a ela confiam a } \\
\text { educação de seus filhos e demais } \\
\text { parentes }\end{array}$ & $\begin{array}{l}\text { D.5. A escola é mesmo boa porque se não fosse, os nossos filhos não estudariam aqui. É raro } \\
\text { uma classe em que o professor não dá aula para um parente seu ...você quer melhor atestado de } \\
\text { que a escola é boa do que este? Meus filhos estudaram aqui, as filhas da diretora também. Que } \\
\text { mais você quer? } \\
\text { D.7. Meus filhos estudaram aqui, minha filha ainda estuda. Eu tenho interesse que a escola seja } \\
\text { boa. Se não fosse boa, quem colocaria os filhos para estudar aqui dentro? } \\
\text { D.8. Você pode perguntar por ai quantos professores põem os filhos para estudar na escola onde } \\
\text { trabalham. Eles podem até falar que a escola é boa, mas põem seus filhos na escola particular. } \\
\text { Minhas duas filhas estudaram aqui ...Quando estavam no colegial, eu vinha de Osasco duas } \\
\text { vezes - de manhã, para dar aula e à noite, para trazer e buscar as meninas. } \\
\text { D.12. Aqui, estudam nossos filhos, sobrinhos ... é dificil uma sala que não tenha um fillho de } \\
\text { uma pessoa que a gente conheça. As pessoas confiam na escola ...só não ponho aqui o meu } \\
\text { filho. porque ele é pequenininho, mas ainda vou por. }\end{array}$ \\
\hline
\end{tabular}




\begin{tabular}{|c|c|}
\hline \multicolumn{2}{|r|}{ CARACTERÍSTICAS DE UMA ESCOLA SAUDÁVEL } \\
\hline IDÉIAS CENTRAIS & EXPRESSŌES-CHAVE \\
\hline $\begin{array}{l}\text { 1. Uma escola saudável é limpa, } \\
\text { espaçosa, conservada, organizada e } \\
\text { arborizada }\end{array}$ & $\begin{array}{l}\text { D.I. Vocé observou que tem muito verde, muita flor ...tem muita vida nessa escola?! Aqui você } \\
\text { vê a presença da vida, você sente a natureza rodeando a escola. } \\
\text { D.2. A escola é saudável e a gente percebe pelo fato de ser uma escola bonita, uma escola que } \\
\text { não é pichada, uma escola muito limpa ...então estes valores de conservação do ambiente físico } \\
\text { estão todos incorporados. } \\
\text { D.3. É uma escola limpa ...caso a gente fosse fazer um giro pela escola, notaria que a escola em } \\
\text { geral. o espaço físico, as árvores, as pessoas, a biblioteca. as salas de aula, o pátio .... é tudo } \\
\text { muito bonito e saudável! } \\
\text { D.5. Acho que vocé já pode ver que a escola é impecável ... está inteira. É arborizada, muito } \\
\text { limpa. muito conservada. Nós cuidamos para que os alunos não sofram nenhum acidente aqui. } \\
\text { cuidlumos das passarclas. } \\
\text { D.6. A escola é limpa, é bonita, é organizada, todas as coisas estão no seu lugar. Não é uma } \\
\text { escola decadente, como muitas que a gente vê por ai. Outra coisa boa é a geometria da escola. } \\
\text { Quando a diretora sai no corredor, tem uma visão panorâmica de toda escola. Aqui não tem } \\
\text { grades. nem andares ...não há portões trancados, ninguém fica isolado. } \\
\text { D.8. A escola é limpa, desde as salas de aula até o refeitório...o prédio é bem construido.... a } \\
\text { escola é muito arborizada. } \\
\text { D. } 10 \text {. Em relação ao espaço fisico, é uma escola arborizada. limpa, conservada e isto ajuda } \\
\text { bastante. Quando o aluno vê a escola limpa, organizada, isto melhora até a maneira como ele } \\
\text { age na sala de aula. Isto ajuda muito na relação com o aluno e no coletivo. }\end{array}$ \\
\hline $\begin{array}{l}\text { 2. Numa escola saudavel as salas de } \\
\text { aula, o patio, o banheiro, a } \\
\text { bibliotcea, o refeitcirio, a sala dos } \\
\text { professores e a sala de video - } \\
\text { enfim, todos os espaços da escola - } \\
\text { sio arejados, limpos, bem } \\
\text { conservados e se constituem em } \\
\text { espaços efetivos de aprendizagem. }\end{array}$ & 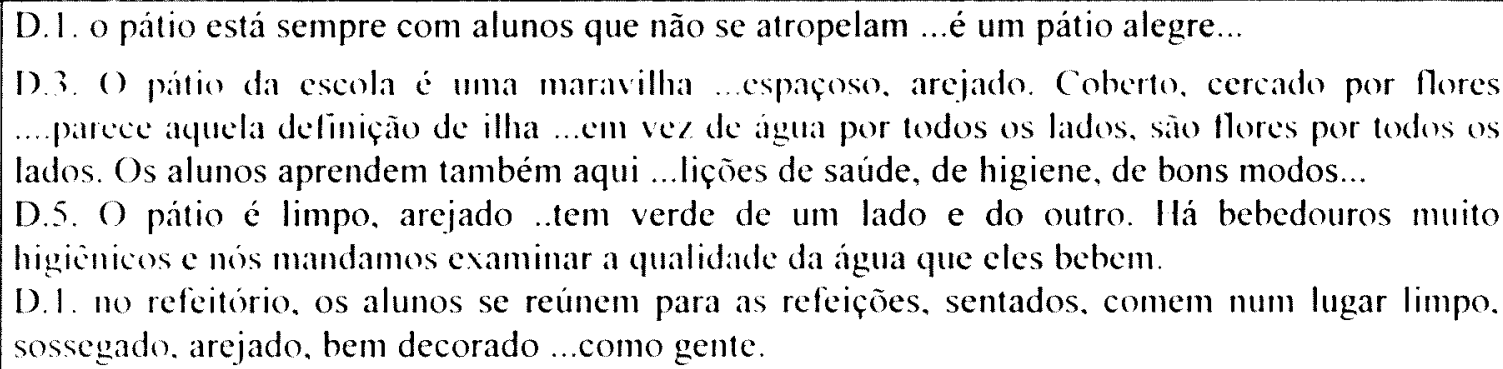 \\
\hline
\end{tabular}




\begin{tabular}{|c|c|}
\hline \multicolumn{2}{|r|}{ CARACTERÍSTICAS DE UMA ESCOLA SAUDÁVEL } \\
\hline IDÉIAS CENTRAIS & \begin{tabular}{|c|} 
EXPRESSÕES-CHAVE \\
\end{tabular} \\
\hline $\begin{array}{l}\text { 2. Numa escola saudável as salas de } \\
\text { aula, o pátio, o banheiro, a } \\
\text { biblioteca, o refeitório, a sala dos } \\
\text { professores e a sala de vídeo - } \\
\text { enfim, todos os espaços da escola - } \\
\text { são arejados, limpos, bem } \\
\text { conservados e se constituem em } \\
\text { espaços efetivos de aprendizagem }\end{array}$ & 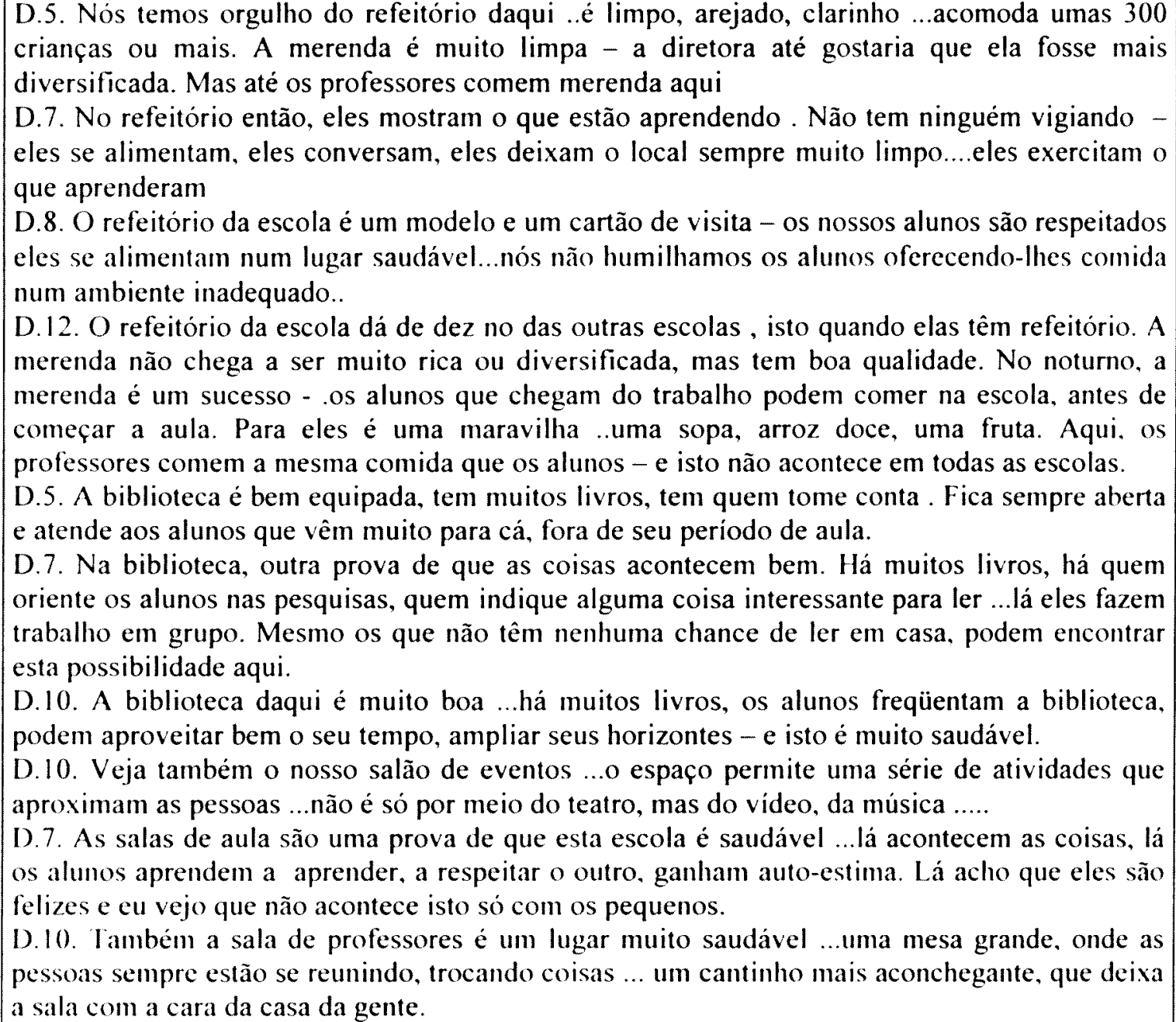 \\
\hline
\end{tabular}




\begin{tabular}{|c|c|}
\hline \multicolumn{2}{|r|}{ CARACTERÍSTICAS DE UMA ESCOLA SAUDÁVEL } \\
\hline IDÉIAS CENTRAIS & EXPRESSŌES-CHAVE \\
\hline $\begin{array}{l}\text { 3. Numa escola saudável as salas de } \\
\text { aula, o pátio, o banheiro, a } \\
\text { biblioteca, o refeitório, a sala dos } \\
\text { professores e a sala de vídeo - } \\
\text { enfim, todos os espaços da escola - } \\
\text { são arejados, limpos, bem } \\
\text { conservados e se constituem em } \\
\text { espaços efetivos de aprendizagem }\end{array}$ & 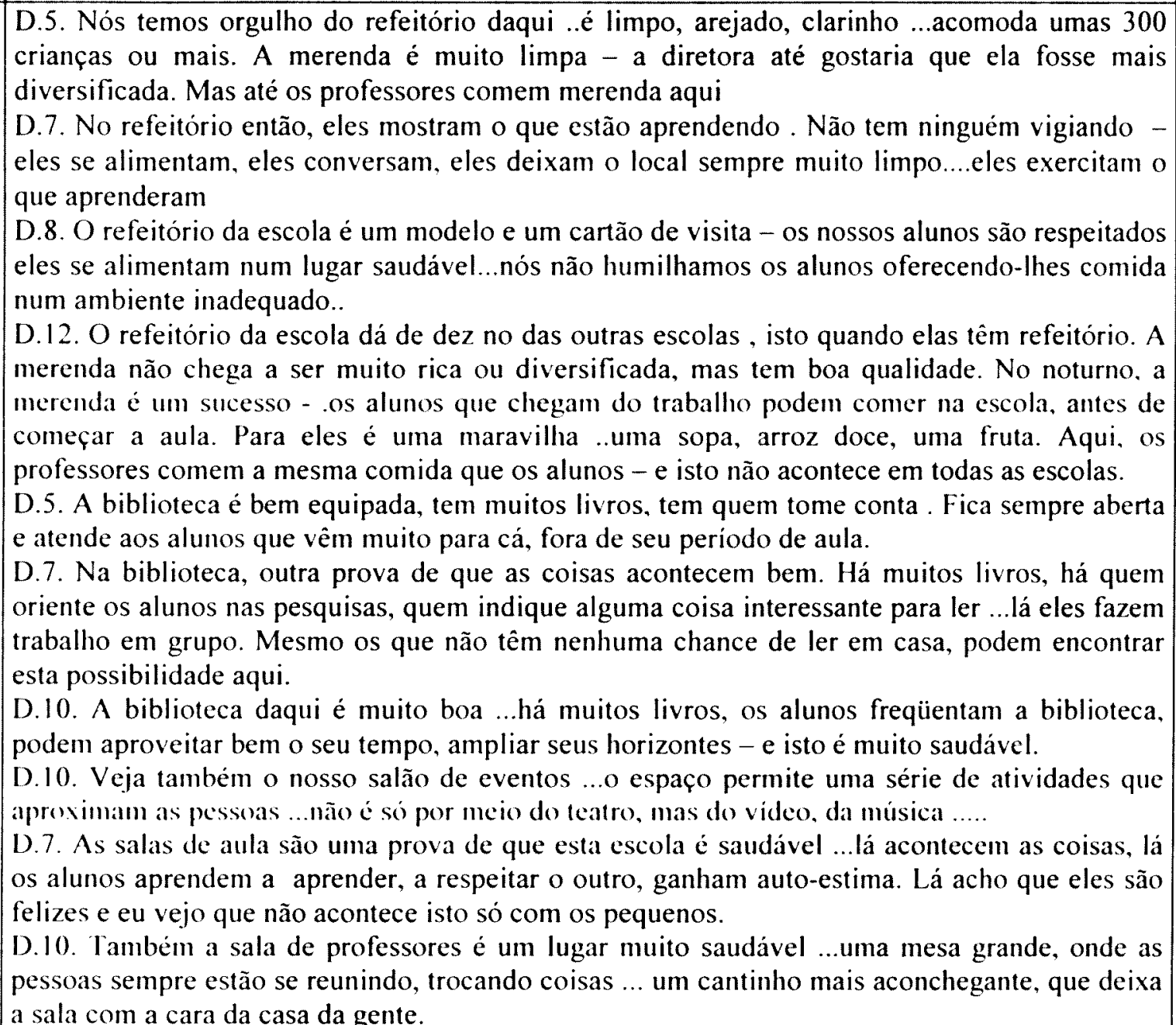 \\
\hline
\end{tabular}




\begin{tabular}{|c|c|}
\hline \multicolumn{2}{|r|}{ CARACTERÍSTICAS DE UMA ESCOLA SAUDÁVEL } \\
\hline $\begin{array}{l}\text { IDÉIAS CENTRAIS } \\
\text { 4. Numa escola saudável as salas de } \\
\text { aula, o pátio, o banheiro, a } \\
\text { biblioteca, o refeitório, a sala dos } \\
\text { professores e a sala de vídeo - } \\
\text { cnfim, todos os espaços da cscola - } \\
\text { são arejados, limpos, bem } \\
\text { conservados e se constituem em } \\
\text { espaços efetivos de aprendizagem }\end{array}$ & $\begin{array}{l}\text { EXPRESSÕES-CHAVE } \\
\text { D.5. Os nossos banheiros são limpos, tanto o dos professores como o dos alunos. A comunidade } \\
\text { sempre mantêm papel higiênico no banheiro ...lá tem espelhos, para eles poderem se olhar, } \\
\text { verificar como estão .... Todos os alunos precisam pedir permissão para ir ao banheiro, até os do } \\
\text { colegial. Há sempre alguém que estranha isto, mas é um hábito bom da escola e, aos poucos, } \\
\text { todos se acostumam. } \\
\text { D.12. Os nossos banheiros são super-limpos- e estou falando dos banheiros dos alunos também. } \\
\text { Temos espelhos no banheiro e papel higiênico. Não é o máximo? Não parece uma escola } \\
\text { particular? Apenas respeitamos os nossos alunos, eles se respeitam, respeitam a escola e fazem } \\
\text { o melhor por ela. }\end{array}$ \\
\hline $\begin{array}{l}\text { 5. Numa escola saudável, o clima } \\
\text { geral e amigável e se percebe um } \\
\text { bom nivel de organização. A } \\
\text { direção e a coordenação pedagógica } \\
\text { estão sempre presentes e cumprem } \\
\text { as suas obrigaçóes com } \\
\text { competência. Estas escolas tem um } \\
\text { projeto escolar claro e conta com a } \\
\text { adesão da comunidade para } \\
\text { implementá-lo. O Conselho de } \\
\text { Classe e a Associação de Pais } \\
\text { funcionam bem. Há seriedade e } \\
\text { profissionalismo por parte dos } \\
\text { professores e todos - professores, } \\
\text { alunos e comunidade - são } \\
\text { responsabilizados pela conservação } \\
\text { da escola. }\end{array}$ & $\begin{array}{l}\text { D.1. Quando a gente entra na escola pela primeira vez, a gente sente que alguma coisa diferente } \\
\text { acontece ... a organização geral desta escola chama a atenção de qualquer um. } \\
\text { D.2. Esta escola é uma boa escola primeiro porque é uma escola organizada ...todos aqui } \\
\text { contribuem para que ela seja uma escola com um clima bom, favorável ao trabalho, que faça } \\
\text { com que todos se sintam bem aqui dentro...Tudo está no seu lugar, não há nenhuma bagunça e } \\
\text { se sabe logo. desde que se entra na escola, que se chegou a um lugar diferente. } \\
\text { D.3. É uma escola bem organizada e de alto austral ...as pessoas são felizes aqui e isto é um } \\
\text { sintoma de que as coisas por aqui são saudáveis. } \\
\text { D.4. Esta escola é muito organizada ...tem que ser limpa, tem que funcionar. tem que fazer o seu } \\
\text { papel de escola - conseguir ensinar. Tem que dialogar muito com os alunos ...acho que } \\
\text { conseguimos muito isso ..é um pouco dificil, mas com o tempo isto vai virando uma boa rotina. } \\
\text { Tem que ter uma equipe integrada ...que sabe o que tem que fazer ...tem que estar afinada com a } \\
\text { comunidade } \\
\text { D.5. O clima da escola é muito bom. Todos têm acesso à direção, ela conhece os pais e alunos } \\
\text { pelo nome. Os alunos gostam daqui ..eles não fogem ...vez ou outra um dá uma escapada, mas } \\
\text { nós ficamos no pé. O aluno tem liberdade de conversar com a direção, com a coordenação. Eles } \\
\text { fazem as suas reivindicações. A escola é muito organizada e se não fosse assim, não sei como } \\
\text { poderia ser uma escola saudável. } \\
\text { D.12. O clima é muito bom, alegre, descontraido. A escola é super-organizada }\end{array}$ \\
\hline
\end{tabular}




\begin{tabular}{|c|c|}
\hline \multicolumn{2}{|r|}{ CARACTERÍSTICAS DE UMA ESCOLA SAUDÁVEL } \\
\hline IDÉIAS CENTRAIS & EXPRESSŌES-CHAVE \\
\hline $\begin{array}{l}\text { 6. Numa escola saudável a direção é } \\
\text { presente e competente, não se } \\
\text { dedicando exclusivamente às tarefas } \\
\text { burocráticas. }\end{array}$ & $\begin{array}{l}\text { D.6. Nesta escola, as pessoas têm um cargo e exercem este cargo. Nas outras escolas, o diretor } \\
\text { não fica } 8 \text { horas na escola - ele trabalha em dois lugares e aparece ou só para abrir ou só para } \\
\text { fechar a escola. O que mais sobrecarrega a estrutura é a parte burocrática - o diretor concentra- } \\
\text { se na burocracia. O coordenador faz papel de porteiro. de secretário... Aqui não. A diretora está } \\
\text { presente o tempo todo - é comprometida, sabe o caso de cada aluno, conhece todos os } \\
\text { professores - o vice diretor apoia o diretor e o trabalho é bem distribuido... coordenador faz o } \\
\text { trabalho pedagogico } \\
\text { D.9. A direção é muito boa e isto influi muito. Ela está sempre na escola c sabe comandar as } \\
\text { coisas. Ela articula tudo muito bem e consegue não pressionar muito. pois isto deixa as pessoas } \\
\text { mais tensas e a coisa não anda }\end{array}$ \\
\hline $\begin{array}{l}\text { 7. Numa escola saudácel a escola } \\
\text { tem um projeto pedagógico } \\
\text { centrado cm valores, projeto este } \\
\text { aprovado e assumido pelos pais, } \\
\text { inclusive no que se refere a sua } \\
\text { implementaça. A comunidade } \\
\text { respeita este projeto e os } \\
\text { profissionais da escola. }\end{array}$ & 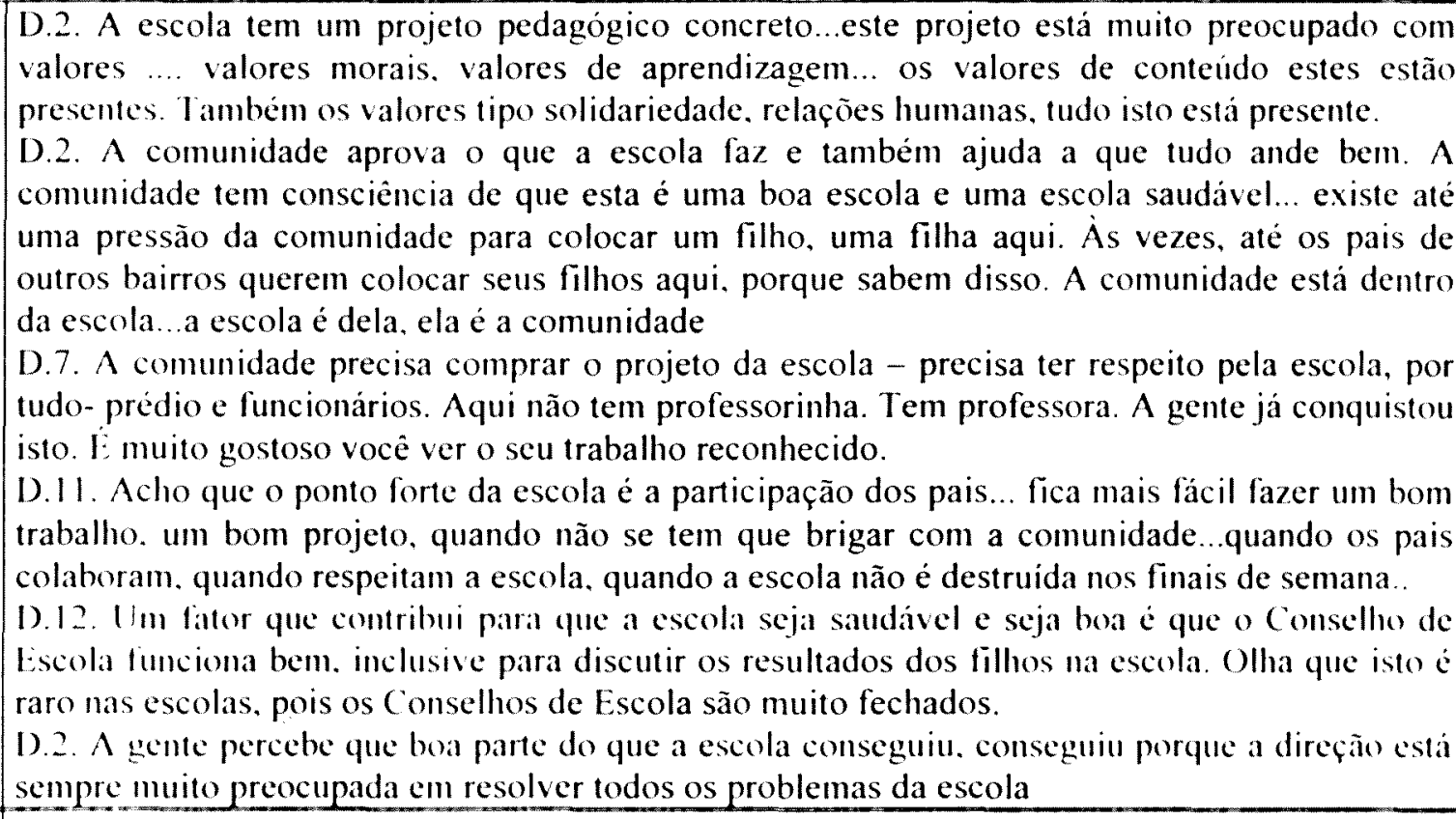 \\
\hline $\begin{array}{l}\text { 8. Numb escola saudácel, os } \\
\text { professores são, em geral, sérios e } \\
\text { respeitam os alunos. }\end{array}$ & $\begin{array}{l}\text { D.2. Os professores gostam de trabalhar aqui e são muito sérios ...é lógico que há exceçoes. mas } \\
\text { acho que cles procuram ser bom profissionais }\end{array}$ \\
\hline
\end{tabular}




\begin{tabular}{|c|c|}
\hline \multicolumn{2}{|r|}{ CARACTERÍSTICAS DE UMA ESCOLA SAUDÁVEL } \\
\hline IDÉIAS CENTRAIS & EXPRESSÕES-CHAVE \\
\hline $\begin{array}{l}\text { 9. Numa escola saudável, os } \\
\text { professores são, em geral, sérios e } \\
\text { respeitam os alunos. }\end{array}$ & $\begin{array}{l}\text { D.12. Acho que os professores respeitam muito os seus alunos... não perdem a calma, não usam } \\
\text { palavrões, como a gente ouve dizer que acontece em outras escolas. Nem todos são iguais, mas } \\
\text { eu estou falando da escola como um todo. }\end{array}$ \\
\hline $\begin{array}{l}\text { 10. Numa escola saudável, os alunos } \\
\text { e a comunidade, em geral, são } \\
\text { responsabilizados pela manutenção } \\
\text { das condiçōes de higiene e de } \\
\text { conservação do prédio e dos } \\
\text { equipamentos escolares. }\end{array}$ & $\begin{array}{l}\text { D.5. Nossos alunos sabem que têm que conservar a escola, pois ela é de todos e vai ser um dia } \\
\text { dos fillos deles. Um dia. dois alunos quebraram alguns vasos - nós não brigamos - chamamos a } \\
\text { familia, explicamos que aquilo era patrimônio nosso - e eles acertaram tudo. Um aluno riscou a } \\
\text { mesa do professor - fizemos a mesma coisa. A mesa ficou mais limpa que antes. É um trabalho } \\
\text { incansável. Sujou, tem que limpar na hora. Tem que conscientizar que a escola é nossa e nós } \\
\text { temos que zelar por ela } \\
\text { D.12. Nós temos o hábito de fazer que os alunos e a comunidade sejam responsáveis pela } \\
\text { conservação da escola. A escola é de todos - e isto vale para tomar conta da escola. Não vejo } \\
\text { como uma escola pode ser boa ou ser saudável, não vejo como formar bons cidadãos se as } \\
\text { crianças e as familias não são chamadas à responsabilidade, com bons modos, com educação, } \\
\text { com transparência. Não é sobrecarregar os pais. mas fazer com que assumam o que tem de ser } \\
\text { assumido por eles. }\end{array}$ \\
\hline $\begin{array}{l}\text { 11. Numa escola saudável, há o } \\
\text { compromisso com o bem estar de } \\
\text { todos, inclusice quanto a manter a } \\
\text { vida funcional de todos } \\
\text { rigorosamente em dia. }\end{array}$ & $\begin{array}{l}\text { D.3. Os professores daqui se preocupam com a comunidade e todo mundo pensa no bem estar } \\
\text { de todos. Não só do corpo docente, mas também dos funcionários. dos alunos, em todos os } \\
\text { aspectos. Não só na ausência da saúde ou na doença, mas no estado social das pessoas que se } \\
\text { encontram na comunidade. Se eu fosse dar uma nota para esta escola, de zero a dez, eu tocava } \\
\text { ela em } 9.5 \text {. } \\
\text { D.5. Esta escola preocupa-se muito também com a vida funcional do professor. A nossa vida é } \\
\text { rigorosamente em dia - adicional, tudo em dia, Eu acho que isso deixa o professor satisfeito, é } \\
\text { uma das coisas que segura o professor aqui. Também é uma forma de contribuir para que a vida } \\
\text { deles seja mellor, pois o salário vai ser mellor e não terão problema na aposentadoria. } \\
\text { D.12. O grupo tem uma preocupação para que a gente viva bem aqui dentro. Tenho amigas que } \\
\text { trabalham em outras escolas e elas têm problemas de drogas, de violéncia ...é lógico que isto } \\
\text { tem em todo lugar. mas nós não temos nada que atrapalhe o trabalho da escola. }\end{array}$ \\
\hline
\end{tabular}




\begin{tabular}{|c|c|}
\hline \multicolumn{2}{|r|}{ CARACTERISTICAS DE UMA ESCOLA SAUDÁVEL } \\
\hline IDÉIAS CENTRAIS & \begin{tabular}{|l} 
EXPRESSŌES-CHAVE \\
\end{tabular} \\
\hline $\begin{array}{l}\text { 12. Numa escola saudável, o foco da } \\
\text { ação pedagógica é a permanência } \\
\text { do aluno na escola e sua } \\
\text { aprendizagem efetiva. Para tanto, } \\
\text { as situações de ensino e e } \\
\text { aprendizagem são diversificadas, } \\
\text { inclusive com a realização de } \\
\text { atividades culturais e utilização de } \\
\text { recursos didático-pedagógicos. }\end{array}$ & $\begin{array}{l}\text { D.I. A escola tem um compromisso com o aluno ...ela faz o que pode para que o aluno } \\
\text { permaneça na escola ... eles estão mais interessados em que os alunos aprendam do que em } \\
\text { colocar os alunos para fora, como em tantas escolas. } \\
\text { D.2. A direção, a coordenação e os professores trabalham para o aluno... para que ele possa se } \\
\text { dar bem aqui. Com já disse, elas não deixam o aluno desistir .. nunca. Elas batalham para que ele } \\
\text { vá bem. seja um bom aluno, consiga ser aprovado. } \\
\text { D.11. Podemos melhorar ainda mais, mas a nossa escola tem alcançado melhores resultados que } \\
\text { as outras. As pessoas de Carapicuiba respeitam os alunos que estudaram no Fornasaro } \\
\text { D.5. Nós saimos sempre com os alunos - todos os anos vamos com eles à Bolsa de Valores e os } \\
\text { nossos alunos são muito elogiados lá. Vamos à Coca Cola e dá para discutir sobre a produção, o } \\
\text { capitalismo - a linha de montagem, a origem da matéria prima ... dá até para ver como somos } \\
\text { explorados - o xarope da Coca Cola vem da Amazônia, porque lá tem canela. Vamos ao Museu } \\
\text { de Arqueologia, da USP. ao Museu do Crime ...enfim, saimos para atividades culturais. Sempre } \\
\text { fomos a Paranapiacaba ...paramos pois ficamos com medo da segurança das pessoas. A escola } \\
\text { tira fotos e essas fotos são mostradas para todos ..eles têm orgulho disto. Vamos a Teatro, a } \\
\text { atividades culturais ...a escola é um polo cultural também. Eles já foram para o programa da } \\
\text { Eliana, já participaram do projeto das Futuras Gerações. A comunidade fica orgulhosa de ver o } \\
\text { trabalho dos fillos. }\end{array}$ \\
\hline $\begin{array}{l}\text { 13. Numa escola saudável, o ensino } \\
\text { é de boa qualidade, observando-se } \\
\text { bons resultados de rendimento e } \\
\text { desempenho escolar. }\end{array}$ & $\begin{array}{l}\text { D.7. Os nossos alunos aprendem e dá muita satisfação de ver como vão progredindo ... eu } \\
\text { sempre encontro meus ex-alunos, aqui mesmo na escola, e pergunto sobre como eles estão se } \\
\text { saindo. E eles se saem bem ...é lógico que um ou outro nem vai tão bem assim } \\
\text { D.6. Esta é uma escola que consegue bons resultados com os alunos. Eles se saem bem também } \\
\text { lá fora, o que prova que nós estamos trabalhando bem. É lógico que sempre se tem que } \\
\text { melhorar. }\end{array}$ \\
\hline
\end{tabular}




\begin{tabular}{|l|l|}
\hline \multicolumn{2}{|c|}{ CARACTERÍSTICAS DE UMA ESCOLA SAUDÁVEL } \\
\hline \multicolumn{1}{|c|}{ IDÉIAS CENTRAIS } & \multicolumn{1}{c|}{ EXPRESSÕES-CHAVE } \\
\hline $\begin{array}{l}\text { 16. Nem toda boa escola é uma } \\
\text { escola saudável }\end{array}$ & $\begin{array}{l}\text { D.4. Nem sempre a escola boa é saudável. Ás vezes, o professor vai lá e faz o seu trabalho. Para } \\
\text { que ela seja saudável, ela tem que brilhar ... profissional tem que dar a sua alma, a sua emoção. } \\
\text { Ou eu vou e me dou por inteiro ou eu não consigo fazer. Ela não só ensina, mas ensina para a } \\
\text { vida...ela não fala só do que é bom, mas oferece um bom ambiente para o aluno e para todos. } \\
\text { D.5. O Fornasaro é uma escola boa e é saudável...mas imagino que nem sempre isto acontece. } \\
\text { Tem escola que é boa no sentido tradicional - tem fama, faz o aluno entrar no vestibular - mas } \\
\text { não promove a saúde dos alunos e nem é agradável por dentro, nem é saudável, como estamos } \\
\text { dizendo. } \\
\text { D.11. já vi escola que é considerada boa que não está nem aí com a qualidade de vida dos } \\
\text { alunos ..que não tem este clima agradável daqui . }\end{array}$ \\
\hline $\begin{array}{l}\text { 17. Toda escola saudável é uma boa } \\
\text { escola }\end{array}$ & $\begin{array}{l}\text { D.2. Agora, toda escola saudável é boa porque ela tende a crescer. Ela procura, insiste e para ser } \\
\text { saudável precisa ensinar bem.. } \\
\text { D.3. Depois de tudo isto que eu falei. acho que uma escola que é saudável tem também que ser } \\
\text { boa. tem que fazer o aluno aprender ...a educação não é um dos requisitos da saúde? } \\
\text { D.4. Será que a gente pode considerar saudável uma escola que expulsa o aluno, que não } \\
\text { consegue fazer com que ele aprenda? Eu acho sinceramente que não e toda escola saudável tem } \\
\text { a obrigação de ser uma boa escola. Aliás, penso que uma das condições para que ela seja } \\
\text { saudável é que ela seja boa. } \\
\text { D.11. Estava querendo dizer que uma escola saudável é por natureza uma boa escola. A escola } \\
\text { não é um hospital... é uma escola. E faz parte de ser saudável que ela faça bem o que precisa } \\
\text { fazer, o que é só ela que faz ...ensinar. }\end{array}$ \\
\hline
\end{tabular}




\begin{tabular}{|c|c|}
\hline \multicolumn{2}{|r|}{ PAPEL DA ESCOLA NA ÁREA DA SAÚDE } \\
\hline IDÉIAS CENTRAIS & EXPRESSÕES-CHAVE \\
\hline $\begin{array}{l}\text { 1. Promoção da saúde, mediante a } \\
\text { articulação constante entre teoria e } \\
\text { prática. }\end{array}$ & 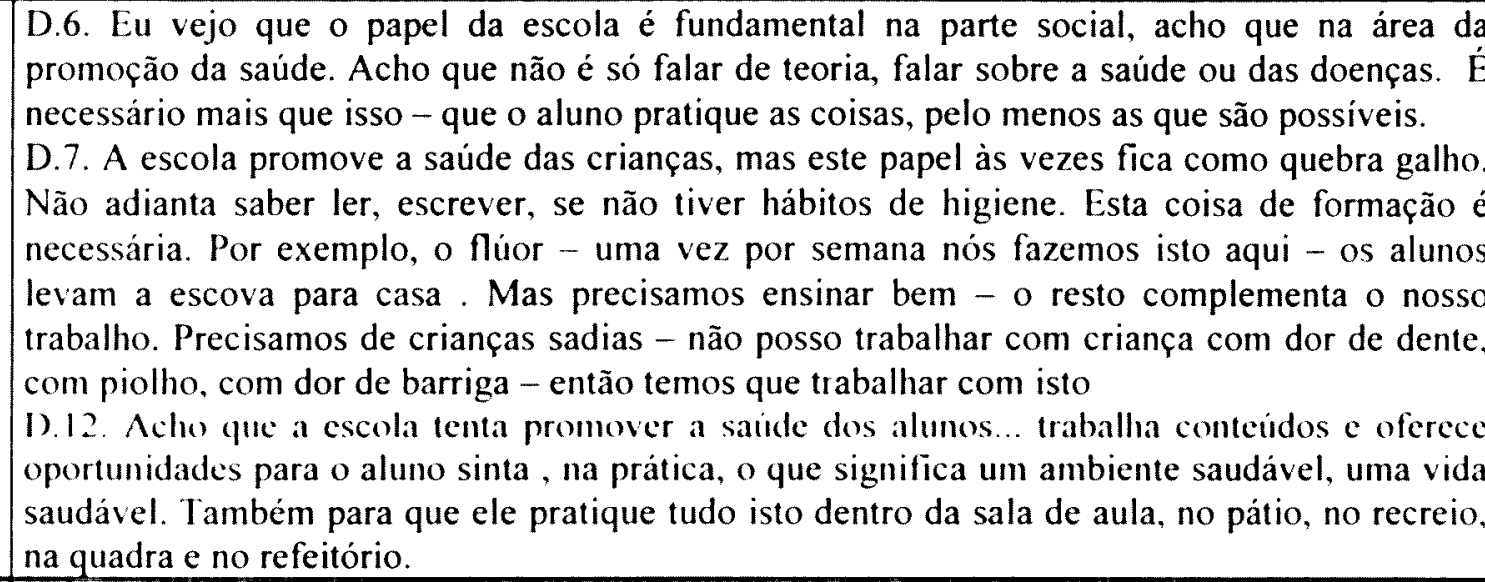 \\
\hline $\begin{array}{l}\text { 2. transmissão de conhecimentos e } \\
\text { divulgação de informações } \\
\text { atualizadas, nos diversos } \\
\text { componentes curriculares }\end{array}$ & $\begin{array}{l}\text { D.1. A escola passa através de seus professores, de seu corpo administrativo, todas as noções } \\
\text { do que seria uma pessoa saudável, o que uma pessoa saudável precisa ter. Ela não fala só da } \\
\text { saúde do corpo, ela trabalha também a saúde do espirito e dá todas as informações } \\
\text { necessárias...está sempre procurando passar conhecimentos de saúde. } \\
\text { D.2. Eu acredito que a escola desenvolve um bom trabalho de saúde divulgando } \\
\text { conhecimentos e tudo o que é informação sobre saúde. Tenho percebido que isto acontece em } \\
\text { todos os projetos que a escola trabalha, em vários componentes curriculares, na área de } \\
\text { ciências, biologia, sociologia, nas relações humanas...tudo isto é trabalhado pela escola com a } \\
\text { comunidade. } \\
\text { D.3. A escola tem que informar mesmo.. não é só isso, mas é também isto } \\
\text { D.6. Trabalho com sexualidade, com DSTs, com contracepção, enfim com os assuntos que } \\
\text { interessam aos adolescentes. A minha disciplina me dá bastante margem para entrar nas } \\
\text { questões de saúde ...saúde fisica, por exemplo, fora isso, fico meio delicado, pois a Delegacia } \\
\text { impede que a realização de atividades de lazer fora da escola, que envolvam un único } \\
\text { professor. Lla faz a exigência de que exista um projeto, que envolva conteúdos e vários } \\
\text { professores. }\end{array}$ \\
\hline
\end{tabular}




\begin{tabular}{|c|c|}
\hline \multicolumn{2}{|r|}{ PAPEL DA ESCOLA NA ÁREA DA SAÚDE } \\
\hline IDÉIAS CENTRAIS & EXPRESSŌES-CHAVE \\
\hline $\begin{array}{l}\text { 3. transmissão de conhecimentos e } \\
\text { divulgação de informaçóes } \\
\text { atualizadias, nos diversos } \\
\text { componentes curriculares }\end{array}$ & $\begin{array}{l}\text { D.8. Esta escola faz um bom trabalho na área de saúde, inclusive no que se refere aos } \\
\text { conteúdos. Desde as séries iniciais, trabalhamos com higiene, sexualidade. Zelamos para que } \\
\text { os menores tomem banho, ensinamos como usar MODESS...juntamos a teoria com a prática. } \\
\text { Orientamos os alunos para que tenham nas escola uma referência ...a escola é uma extensão } \\
\text { da casa e nós orientamos assim nossos alunos. Temos que conservar a escola como } \\
\text { conservamos a nossa casa. } \\
\text { A escola tem um grande papel de estar colaborando para que os alunos tenham os } \\
\text { conhecimentos certos de saúde. Na Educação Física... em Ciências, isto integrado com todas } \\
\text { as outras disciplinas. A escola precisa trabalhar conteúdos de saúde. Nas minhas aulas eu } \\
\text { sempre ajudo as outras professoras que estão trabalhando com conteúdos de saúde. }\end{array}$ \\
\hline 4. orientação de pais e alunos & 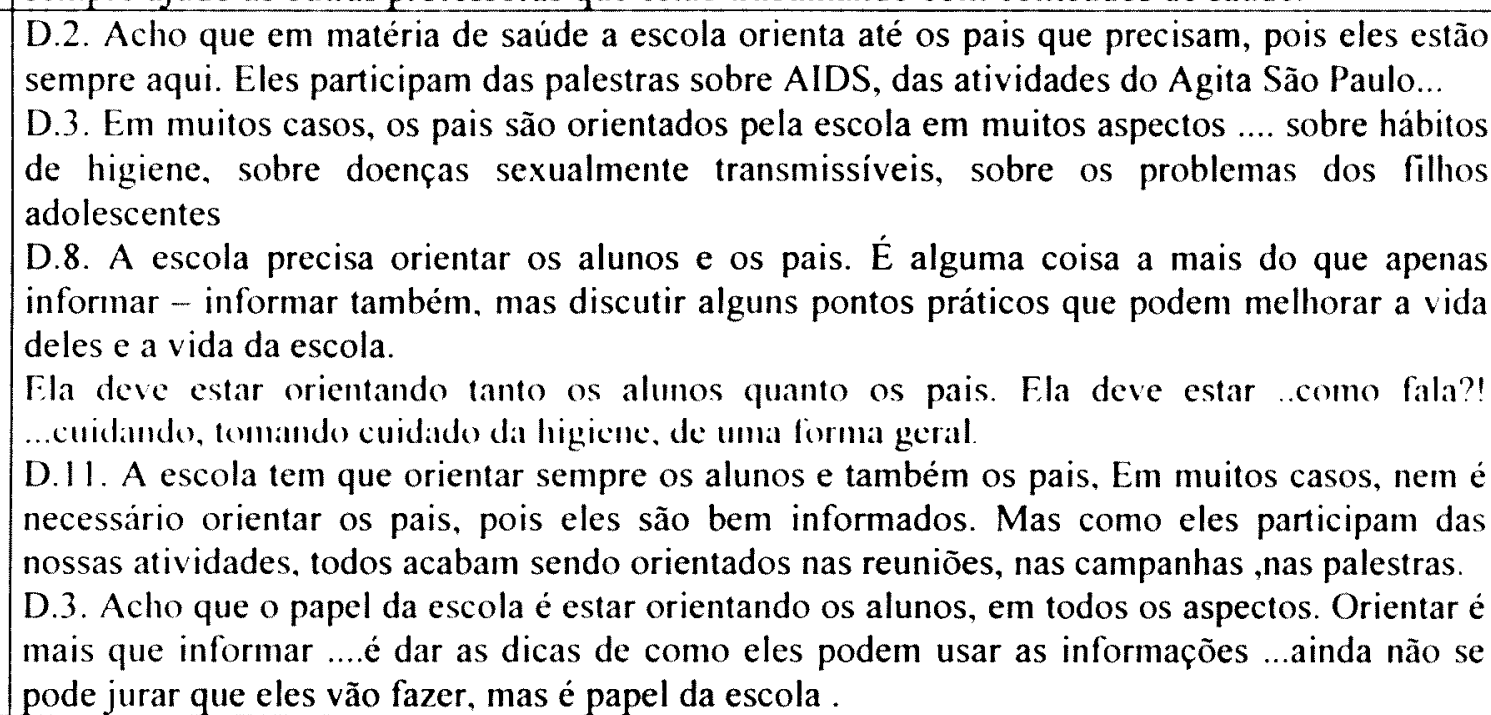 \\
\hline
\end{tabular}




\begin{tabular}{|c|c|}
\hline \multicolumn{2}{|r|}{ PAPEL DA ESCOLA NA ÁREA DA SAÚDE } \\
\hline IDÉIAS CENTRAIS & $\begin{array}{l}\text { EXPRESSÕES-CHAVE } \\
\end{array}$ \\
\hline 5. formação de valores & 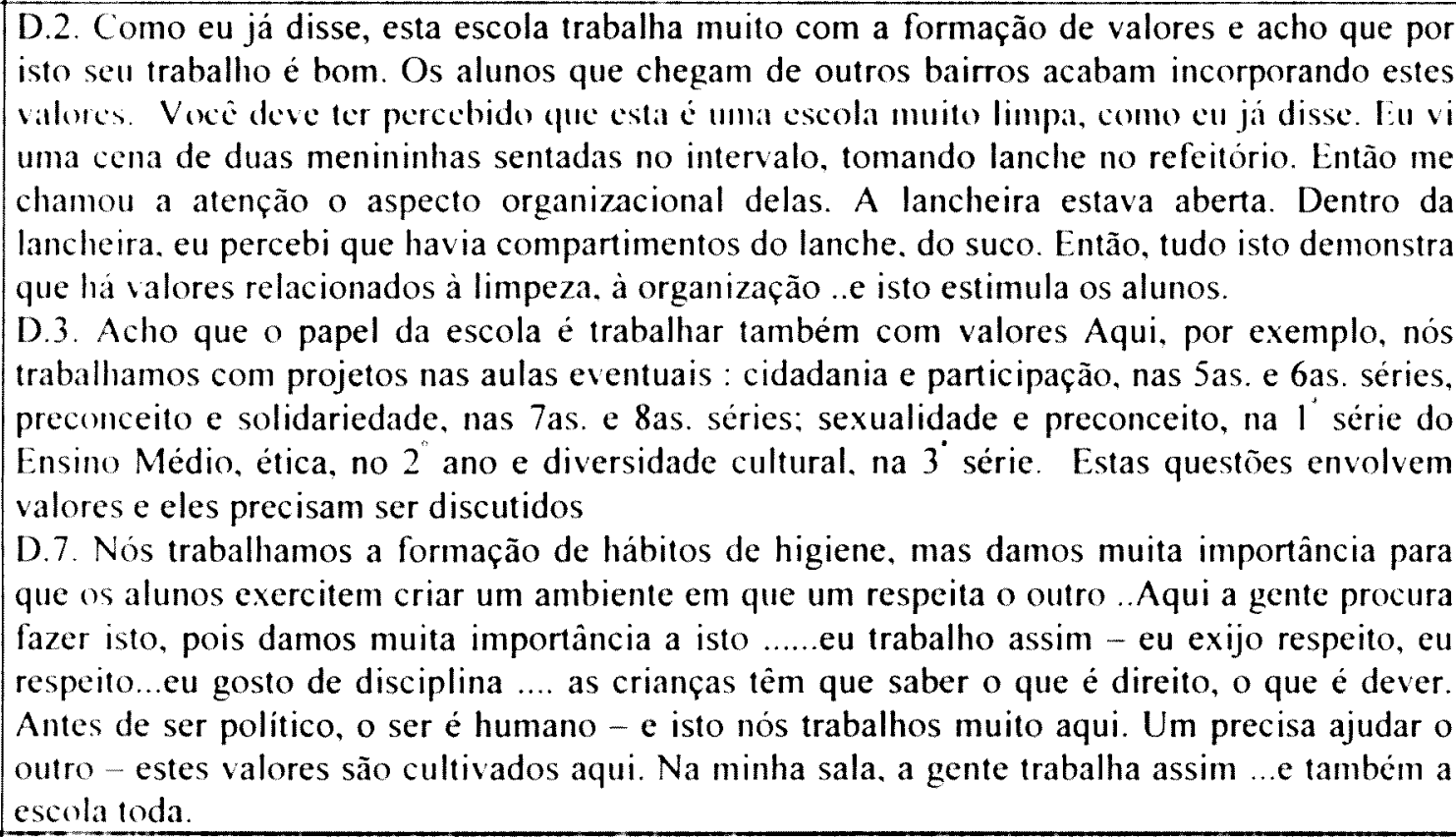 \\
\hline $\begin{array}{l}\text { 6. encaminhar alunos para } \\
\text { atendimento médico e odontológico }\end{array}$ & $\begin{array}{l}\text { D.5. Temos que encaminhar também os alunos que precisam de atendimento ... encaminhamos } \\
\text { para o postinho. batalho para que os nossos alunos sejam atendidos e bem atendidos. Telefono } \\
\text { para o pessoal da saúde, converso com as mães, com as crianças...verifico se foram bem } \\
\text { atendidas. Era mais fácil quando a gente tinha dois dentistas da prefeitura aqui. mas não } \\
\text { podemos ficar lamentando. } \\
\text { D.6. Acho que a escola deveria contar com serviços de saúde. Nós tínhamos dentistas e na } \\
\text { atual situação, o prefeito tirou os dentistas daqui. Mas temos que continuar com os } \\
\text { encaminhamentos necessários, para o postinho da prefeitura. Também se determinado aluno } \\
\text { causa algum problema na sala de aula, seja porque ele tem um problema mental ou sei lá o } \\
\text { que. precisa encaminhar. } \\
\text { D.8. Não temos assistência médica e odontológica na escola, mas nõo podemos lavar as mãos } \\
\text { quando os nossos alunos estão doentes. Nós encaminhamos os alunos com problemas para o } \\
\text { postinlon- é sempre melhor que nada. }\end{array}$ \\
\hline
\end{tabular}




\begin{tabular}{|l|c|}
\hline \multicolumn{1}{|c|}{ IDÉIAS CENTRAIS } & PAPEL DA ESCOLA NA ÁREA DA SAÚDE \\
\hline $\begin{array}{l}\text { 7. Informar às familias sobre a } \\
\text { disponibilidade de atendimento na } \\
\text { região e manter-se atento quanto a } \\
\text { crentuais problemas apresentados } \\
\text { pelos alunos }\end{array}$ & $\begin{array}{l}\text { D.5 Acho que a escola também deve esclarecer aos alunos e às familias sobre como podem ser } \\
\text { atendidos na comunidade ...quem procurar em caso de necessidade. Também devemos ficar } \\
\text { atentos para perceber alguma situação que a familia não percebeu e encaminhar. }\end{array}$ \\
\hline $\begin{array}{l}\text { 8. Assegurar a permanência dos } \\
\text { alunos na escola e o seu sucesso } \\
\text { escolar }\end{array}$ & $\begin{array}{l}\text { D.6. O ponto que eu vejo positivo nesta escola é o seguinte: se eu tenho um problema com um } \\
\text { aluno e o encaminho para a direção ou coordenação, nunca se parte para afastar o aluno .... } \\
\text { escola procura conhecer o problema do aluno. qual será o motivo do trauma do aluno. Aqui } \\
\text { vale o ditado : bater não adianta - tem que recorrer ao diálogo. Nosso objetivo é trazer o } \\
\text { aluno para a aula, para dentro da sala de aula ...nunca afastar. Neste sentido. a direção e a } \\
\text { coordenação pedagógica ajudam bastante. A gente chama os pais, envolve todo mundo. E isto } \\
\text { é o mínimo que a escola precisa fazer para que os alunos sejam cidadãos com saúde : que } \\
\text { saibam ler, escrever, conversar, argumentar...essas coisas. }\end{array}$ \\
\hline $\begin{array}{l}\text { 9. Assegurar aos alunos uma } \\
\text { cducação integral }\end{array}$ & $\begin{array}{l}\text { D.4. O papel da escola é fazer com que o aluno se torne uma pessoa, consiga viver de uma } \\
\text { forma digna lá fora. É meio antigo, mas a escola tem que dar ao aluno uma formação integral. } \\
\text { Fntão, nós sempre procuramos fazer isto com nossos alunos. Nós não temos aqui caso de } \\
\text { professor que apanhou de aluno, de aluno que faz represália ao professor. E o papel principal } \\
\text { da escola é conseguir que o aluno venha e fique na escola - numa boa escola. Orientar, } \\
\text { informar. viver aqui uma experiência gostosa, boa. interessante. Aprender - é por aí. }\end{array}$ \\
\hline
\end{tabular}




\begin{tabular}{|c|c|}
\hline \multicolumn{2}{|c|}{ CARACTERÍSTICAS DO PROCESSO DE CONSTRUÇÃO DE UMA ESCOLA SAUDÁVEL } \\
\hline IDÉIAS CENTRAIS & $\begin{array}{ll}\text { EXPRESSŌES - CHAVE } \\
\end{array}$ \\
\hline $\begin{array}{l}\text { 1.1. O tempo de construção de uma } \\
\text { escola saudável varia entre um e } \\
\text { quatro anos }\end{array}$ & $\begin{array}{l}\text { D.1. Eu acho que a escola precisa pelo menos ter uma caminhada; uma caminhada de uns } \\
\text { dois anos ...o grupo todo juntos...um pouquinho mais. } \\
\text { D.2. A grosso modo, acho que levaria uns dois ou três anos para que a escola se torne } \\
\text { saudável. } \\
\text { D.3. Estou aqui há três anos e eu acho que a escola é saudável...acho que esta escola é } 9,5 \\
\text { para ela, então para o dez, deve faltar um ano, por aí. Acho que uns quatro anos para a escola } \\
\text { se transformar numa escola saudável nota } 10 \text {. } \\
\text { D.4. Acho que uns três anos com uma equipe básica é um bom tempo para a escola se tornar } \\
\text { saudável ...depois. é questão de sempre ir acerando o que ainda precisa acertar. Manter uma } \\
\text { escola boa e saudável é tarefa de todos e da vida inteira. Até a noção do que é uma boa e } \\
\text { uma escola saudável muda com o tempo - assim, a escola não pode parar. } \\
\text { D.6. Pouquissimo tempo. Em um ano acho que a direção consegue mudar o astral da escola. }\end{array}$ \\
\hline $\begin{array}{l}1.20 \text { processo de construção de } \\
\text { uma escola saudável é contínuo, o } \\
\text { que inviabiliza a fixação de um } \\
\text { tempo determinado para que isto } \\
\text { aconteça. }\end{array}$ & $\begin{array}{l}\text { D.5. Eu considero que a nossa escola é uma escola saudável e foi um processo lento, uma } \\
\text { construção no decorrer dos anos. Aos poucos você vai incorporando as coisas boas, tirando } \\
\text { aquilo que é ruim. Se bem que eu reconheço que as coisas vão mudando muito rapidamente. } \\
\text { Num dia em que há uma rebelião numa delegacia de polícia, o helicóptero está lá mostrando. } \\
\text { Acontece aqui e já está passando na rede Globo, na Europa ...é uma coisa simultânea, Mas na } \\
\text { escola a coisa tem que ser mais lenta e você pode até me achar conservadora. Eu acho que } \\
\text { tem que parar, tem que pensar, analisar: o que não está bom, volta para trás } \\
\text { D.7. É um trabalho da vida inteira. Precisa acompanhar, verificar os resultados, corrigir... } \\
\text { D.8. Este é um trabalho de longo tempo. Estamos hoje colhendo os frutos de um trabalho que } \\
\text { foi iniciado há muito tempo atrás. Não podemos deixar a peteca cair ... temos que continuar } \\
\text { com a qualidade. Há escolas por ai que são um horror. } \\
\text { I).9. Acho que leva muito tempo e exige um diálogo constante cm pais, alınos c professores. } \\
\text { Os pais precisam participar muito, como acontece aqui. } \\
\text { D.10. Não dá para se descuidar de nada quando a escola quer ser saudável de verdade. Por } \\
\text { isto acho que não dá para dizer quanto tempo demora ...acho que é a vida toda. }\end{array}$ \\
\hline
\end{tabular}




\begin{tabular}{|c|c|}
\hline \multicolumn{2}{|c|}{ CARACTERISTICAS DO PROCESSO DE CONSTRUÇÃO DE UMA ESCOLA SAUDÁVEL } \\
\hline IDÉIAS CENTRAIS & EXPRESSÕES - CHAVE \\
\hline $\begin{array}{l}\text { 1. 2. O processo de construção de } \\
\text { uma escola saudável é continuo, o } \\
\text { que inviabiliza a fixação de um } \\
\text { tempo determinado para que isto } \\
\text { aconteça }\end{array}$ & $\begin{array}{l}\text { D.11. Uma escola boa e saudável não se faz do dia para noite e nem tem um dia em que ela } \\
\text { amanhece saudável. Para que ela seja boa e saudável, precisa estar atenta todo o tempo, todos } \\
\text { os dias, todos os minutos. O resultado é bom mas o processo é cansativo } \\
\text { D.12. Não há limite de tempo para a escola se tornar saudável ...isto é diário ... cada dia a } \\
\text { escola tem que tomar cuidado para não deixar de ser saudável. A escola não é saudável ...ela } \\
\text { está saudável... se a escola tomar atitudes erradas, ela pode deixar de ser saudável. A escola é } \\
\text { formada por pessoas e ela vai ser saudável dependendo se as pessoas que formam ela estão } \\
\text { agindo neste objetivo, Por exemplo, se mudar a direção, se o diretor não tem mais este } \\
\text { objetivo, se os professores não colaborarem .... uma escola que é considerada saudável, no } \\
\text { outro ano pode deixar de ser saudável. }\end{array}$ \\
\hline $\begin{array}{l}\text { 2. Condições essenciais para a } \\
\text { construçao de uma escola saudável } \\
\text { 2.1. Boa estrutura fisica }\end{array}$ & $\begin{array}{l}\text { D.9. Primeiro a escola tem que ter um bom prédio, com os ambientes pedagógicos } \\
\text { necessários para que se faça um trabalho bom e saudável. }\end{array}$ \\
\hline $\begin{array}{l}\text { 2.2. Processo compartilhado entre } \\
\text { todos, inclusive com a comunidade }\end{array}$ & $\begin{array}{l}\text { D.2. E preciso reunir os professores, reunir a comunidade constantemente - que é o que esta } \\
\text { escola faz. E a comunidade, aos poucos, vai assumindo a escola. Então, seria um trabalho } \\
\text { paulatino, sem nunca esmorecer. } \\
\text { D.3. Para a escola se transformar numa escola saudável é preciso um trabalho coletivo - acho } \\
\text { que isto é essencial ...e coletivo não é apenas juntar o povo da escola ...é trazer a comunidade } \\
\text { para dentro da escola, como esta escola faz e faz bem. } \\
\text { D.4. Para quic unla escola seja boa e saudivel ela precisa abrir suas portas para a } \\
\text { comunidade - precisa se abrir por dentro, aparar as arestas, formar um grupo que faça } \\
\text { mesmo e convença os outros a também fazerem o mesmo. Mas se abrir para fora também - } \\
\text { repito muito. mas se a escola não serve á comunidade, ela é depredada. roubada, invadida. } \\
\text { D.5. Precisa ser um trabalho de todos - de dentro e de fora da escola. Hoje mesmo, nas horas } \\
\text { de trabalho pedagogico, nós discutimos uma postura conjunta do corpo docente - dissemos } \\
\text { que quem destoar, o grupo vai cobrar. Temos que estabelecer o diálogo como regra } \\
\text {...conversar sempre, tornar a escola agradável. }\end{array}$ \\
\hline
\end{tabular}




\begin{tabular}{|c|c|}
\hline \multicolumn{2}{|c|}{ CARACTERISTICAS DO PROCESSO DE CONSTRUÇÃO DE UMA ESCOLA SAUDÁVEL } \\
\hline IDÉIAS CENTRAIS & EXPRESSÕES - CHAVE \\
\hline $\begin{array}{l}\text { 2.2. Processo compartilhado entre } \\
\text { todos, inclusive com a comunidade }\end{array}$ & $\begin{array}{l}\text { D.8. É fundamental a participação de todos... comunidade, funcionários, professores, alunos. } \\
\text { A escola é de todos e só funciona bem quando estiver muito articulada à comunidade. Aqui, } \\
\text { nós temos muito a participação dos pais e isto tem sido fundamental. Os pais estão dentro da } \\
\text { escola - na APM, no Conselho de Escola ...tenho muitos amigos que foram os pais dos meus } \\
\text { alunos. Há um elo muito grande entre os professores, os alunos e os pais. Por isto é que esta } \\
\text { escola é ótima. } \\
\text { D. } 10 \text { Em primeiro lugar. acho que todos precisam estar sintonizados com um projeto único - } \\
\text { e todos inclui também a comunidade. conforme eu já falei. Se não tiver este coletivo. não dá } \\
\text { para cluerer mudar a escola para mellhor. } \\
\text { D. } 11 \text {. Não é uma coisa de uma ou duas pessoas nem só de dentro da escola. É uma tarefa do } \\
\text { grupo da escola e da comunidade. Esta união dá força para todo mundo...quando alguém } \\
\text { desanima. o outro está lá para encorajar. } \\
\text { D.12. Para transformar a escola, todos precisam se unir. Tem que ter alguém ou um grupo } \\
\text { para estimular sempre, mas todos têm que participar, inclusive os pais e alunos. }\end{array}$ \\
\hline 2.3. Vontade de querer fazer & $\begin{array}{l}\text { D.2. O primeiro passo seria a vontade de querer fazer do dirigente, dos pais, do pessoal de } \\
\text { apoio, do vice- diretor, dos coordenadores. } \\
\text { D.4. Precisa ter vontade de fazer ...precisa acreditar que se pode fazer ... mas precisa de muita } \\
\text { paixão para isto. conforme diz o Ruben Alves. } \\
\text { D.5. A equipe precisa querer fazer ...precisa ter coragem de se responsabilizar pela melhoria } \\
\text { da qualidade da escola...precisa arregaçar as mangas e fazer. } \\
\text { D.7. Precisa de boa vontade de todo mundo - dos pais, dos alunos - os alunos vão seguir o } \\
\text { exemplo dos professores, vão seguir o modelo da escola.. } \\
\text { D.8. Fazer a escola dar certo. fazer com que ela possa promover a qualidade de vida de todos } \\
\text { não é tão simples assim ...precisa e muito de vontade de fazer. Se não for deste jeito, não sai } \\
\text { nada de bom. } \\
\text { D.11. É preciso querer fazer...vontade de fazer. Se a gente se acomodar, não tem jeito. } \\
\text { D.12. Se não houver uma vontade coletiva, a escola fica patinando e se perde }\end{array}$ \\
\hline
\end{tabular}




\begin{tabular}{|c|c|}
\hline \multicolumn{2}{|c|}{ CARACTERÍSTICAS DO PROCESSO DE CONSTRUÇÃO DE UMA ESCOLA SAUDÁVEL } \\
\hline IDÉIAS CENTRAIS & EXPRESSÕES - CHAVE \\
\hline $\begin{array}{l}\text { 2.4. Ambiente que permite a prática } \\
\text { da saúde na relação entre alunos, } \\
\text { funcionários e professores. }\end{array}$ & $\begin{array}{l}\text { D.1. A escola deve saber passar o conceito de saúde, não de uma forma falada, mas que os } \\
\text { alunos, professores e funcionários pratiquem essa saúde no exercicio da convivência com o } \\
\text { outro. E que as pessoas que aqui dentre estejam, entendam e usem essa saúde em beneficio } \\
\text { próprio. }\end{array}$ \\
\hline $\begin{array}{l}\text { 2.5. Estimulação e cobrança } \\
\text { constantes }\end{array}$ & $\begin{array}{l}\text { D.2. Precisa estimular toda hora e cobrar sempre. Eu me lembro, quando fui diretor de } \\
\text { escola, da fala de um professor de Educação Fisica - ele falava: "Professor, outra vez este } \\
\text { discurso"? Então, isso é uma constante. É preciso repetir isso o tempo todo. Para que a escola } \\
\text { assuma isso...para que os professores assumam ...para que a comunidade assuma e. por } \\
\text { tabela. para que os alunos assumam todos estes valores. É um trabalho a longo prazo. } \\
\text { D.5. Precisa de estimulo e de cobrança. O que você percebe que num ano falhou, no outro } \\
\text { você procura consertar. O que vocé viu que era bom, aumenta aquilo. Aquilo que você viu } \\
\text { que era preciso ser feito, você chama alguém, pede ajuda. Se não for desse jeito. vendo cada } \\
\text { passo, não dá } \\
\text { D.6. Precisa ter alguém que dê o start e que cobre sempre. Precisa ter alguém que alavanque. } \\
\text { lila tem que reunir um grupo de força que tenha as mesmas idéias. A partir dai. é questão de } \\
\text { estabelecer combinações, estabelecer as regras do novo jogo. Precisa de alguém que consiga } \\
\text { chamar pessoas para a mesma idéia ...precisa de ter força de convencimento } \\
\text { D.12. Eu disse que para a escola ser saudável precisa de alguém para estimular } \\
\text { sempre...precisa também cobrar sempre. na boa. com respeito. Mas cobrar. }\end{array}$ \\
\hline 2.6. Autonomia da escola & $\begin{array}{l}\text { D.3. A liberdade, a autonomia. Eu considero esta escola saudável porque existe liberdade } \\
\text { para nós trabalharmos e para o aluno pesquisar, estudar e perguntar tudo o que quiserem. E } \\
\text { nós devemos centrar nosso trabalho nisto - na liberdade. É claro que toda liberdade tem que } \\
\text { ser um pouco controlada, porque são as normas que sustentam as relações entre as pessoas, } \\
\text { mas falar em projeto de escola sem autonomia e sem responsabilidade não está com nada }\end{array}$ \\
\hline
\end{tabular}




\begin{tabular}{|c|c|}
\hline \multicolumn{2}{|c|}{ CARACTERISTICAS DO PROCESSO DE CONSTRUÇÃO DE UMA ESCOLA SAUDÁVEL } \\
\hline IDÉIAS CENTRAIS & EXPRESSÕES - CHAVE \\
\hline $\begin{array}{l}2.7 . \quad \text { Profissionais precisam } \\
\text { acreditar no novo, em si mesmos, na } \\
\text { comunidade e na equipe e criar um } \\
\text { clima de amizade }\end{array}$ & $\begin{array}{l}\text { D.3. As pessoas precisam acreditar em si e nos outros. Eu acho que em alguns momentos as } \\
\text { pessoas me julgam um bobo ou um "puxa-saco". Mas eu acredito na comunidade e acredito } \\
\text { na escola. Para integrar o pessoal da escola precisa de amizade. A amizade é o principal. } \\
\text { Acho que as pessoas chegam na escola com receio, com muitos tabus. As pessoas só } \\
\text { acreditam naquilo que elas já vivenciaram... elas não acreditam no novo. Então, numa } \\
\text { amizade, você vai mostrando às pessoas como as coisas são feitas, como as coisas são } \\
\text { constituidas. E as pessoas começam a se abrir um pouco mais. Elas chegam presas. Então } \\
\text { quando você vai chegando mais nas pessoas, elas vão se soltando. As pessoas ficam } \\
\text { assustadas de inicio. Eu estou presenciando isto agora. Tem pessoas ai que estão com a cara } \\
\text { que parece... Mas com o tempo vai mudando. } \\
\text { D.5. Acho que as pessoas têm um pouco de medo do novo ...eu tenho, pelo menos. Para a a } \\
\text { escola ser cada vez melhor e mais saudável, ela precisa perder este medo ...se cada um } \\
\text { souber que o outro também tem medo, acho que já é um passo para a frente. O novo tem que } \\
\text { ser melhor do que o velho ...não é qualquer novo...a educação está cheia de modismos. }\end{array}$ \\
\hline $\begin{array}{l}\text { 2.8. Presença física da direção na } \\
\text { escola e reconhecida competência } \\
\text { administrativa }\end{array}$ & $\begin{array}{l}\text { D.4. Eu estou sempre aqui - e todos sabem que podem contar comigo e deixam claro que eu } \\
\text { posso contar com eles. Eu compartilho com todos a tarefa de dirigir esta escola, mas assumo } \\
\text { o meu pedaço. }\end{array}$ \\
\hline $\begin{array}{l}2.9 . \quad \text { Projeto da } \quad \begin{array}{r}\text { escola } \\
\text { comprometido } \\
\text { desenvolvimento de valores }\end{array} \\
\end{array}$ & $\begin{array}{l}\text { D.2. Para a escola ser saudável precisa desenvolver valores. Eu tenho } 5 \mathrm{I} \text { anos ...e eu respeito } \\
\text { estes valores de organização, de respeitabilidade, de se dirigir às outras pessoas, maneira de } \\
\text { se comportar, de estar bem vestido. }\end{array}$ \\
\hline $\begin{array}{l}\text { 2. 10. Escola abandona a cultura do } \\
\text { fracasso escolar em favor da cultura } \\
\text { do sucesso escolar, elegendo o aluno } \\
\text { como foco do seu trabalho. }\end{array}$ & $\begin{array}{l}\text { D.5. Para que a escola seja boa e saudável, a nossa preocupação tem que ser com o aluno. } \\
\text { Nós temos que ter sempre isto presente, senão a gente se perde. Limpa a escola, compra } \\
\text { materiais interessantes. faz passeios. mas nada que represente alguma coisa para o aluno. Se } \\
\text { a escola muda e nada muda para melhor na sala de aula, acho que não adianta. Se o aluno se } \\
\text { sente bem na escola, se a escola é limpa e bonita, se o professor dá uma aula boa, a escola } \\
\text { será saudável. }\end{array}$ \\
\hline
\end{tabular}




\section{CARACTERÍSTICAS DO PROCESSO DE CONSTRUÇÃO DE UMA ESCOLA SAUDÁVEL}

IDÉIAS CENTRAIS

D.7. Eu acho que o meu trabalho começa na minha classe. Eu procuro passar para os meus 2. 10. Escola abandona a cultura do alunos o que eu penso ... quando me proponho a alguma coisa, eu não ligo de ficar além do fracasso escolar em favor da cultura do sucesso escolar, elegendo o aluno como foco do seu trabalho.

meu horário ...meus filhos estudaram aqui, minha filha ainda estuda. Eu tenho interesse que a escola seja boa. Mesmo interessada em resolver a coisa dentro da minha sala, se eu vejo alguma coisa diferente eu falo. Percebi que meus alunos não estão desenvolvendo certos valores - e achei necessário fazer isto. Alguma coisa para desenvolver a solidariedade, vamos ajudar o seu coleguinha: Vamos ajudar o outro. Se a gente faz isto de pequeno, quem ajuda não vai se considerar um caxias ou um idiota. Quem precisa de ajuda, vai saber solicitar a ajuda. Eu vejo o meu aluno muito tempo aqui dentro da escola e não apenas durante o ano que ele é meu aluno. Sigo ele ano a ano. Já vi aluno meu ser assassinado, já vi aluno meu virar médico, A gente consegue lembrar das características dos alunos que não deram certo ...e eu fico atenta. Os que precisam mais, eu dou mais atenção.

D.8. Sou profissional e tenho amor naquilo que faço. Para lidar com crianças, precisa ter amor. Tenho amor pelas crianças - respeito as crianças e trabalho para elas. Faço o que posso e o que não posso para que o nosso trabalho seja interessante, para que elas se sintam bem na escola, para que possam progredir e se realizar na vida. O objetivo do meu trabalho são as crianças e acho que esta é a minha contribuição pessoa para que a escola seja boa e saudavel. Pode parecer pouco, mas se todos fizerem bem a sua parte. as coisas vão entrando nos eixos, como aqui no Fornasaro.

D.11. Me entroso com o grupo, participo das atividades coletivas, troco bastante com eles, mas acho que a minha maior contribuição é o trabalho que faço em sala de aula. Levo sério o meu trabalho, encaro o meu aluno como uma pessoa, me empenho para saber o que ele já sabe e fazer ele crescer.... eles se valorizam mais e viram gente grande, boa, saudável, que sabe o que quer, que sabe fazer, que sabe conseguir as coisas. Se todos os professores fizerem assim acho que é muito.

D. 12. Vou repetir o que já disse - a escola tem que estar voltada para o aluno ...tem que dialogar sempre com ele ... se a gente não manter um diálogo saudável com os alunos, nada vai ser saudável.

D.7. Precisa mudar o conceito de escola - nosso país rotula tudo - a nossa escola não está fracassada. Para começar, uma escola saudável precisa ser acreditada. Se os professores não acreditam, se os pais não acreditam, os filhos também não acreditam. Precisa mudar esta imagem da escola. 


\begin{tabular}{|c|c|}
\hline \multicolumn{2}{|c|}{ CARACTERÍSTICAS DO PROCESSO DE CONSTRUÇÃO DE UMA ESCOLA SAUDÁVEL } \\
\hline IDÉIAS CENTRAIS & EXPRESSÕES - CHAVE \\
\hline $\begin{array}{l}\text { 2. 10. Escola abandona a cultura do } \\
\text { fracasso escolar em favor da cultura } \\
\text { do sucesso escolar, elegendo o aluno } \\
\text { como foco do seu trabalho. }\end{array}$ & $\begin{array}{l}\text { D.10. Acredito que o acesso à educação é uma das condições para que um povo seja } \\
\text { saudável. Assim, é necessário que o aluno possa freqüentar uma escola, qualquer que seja, } \\
\text { pois é melhor uma escola que não é muito boa do que nenhuma escola. Depois, o aluno deve } \\
\text { ter condições de poder ficar na escola ...deve ter aulas interessantes...deve ter a sua realidade } \\
\text { considerada. Ele deve se sentir bem na escola , precisa ser bem sucedido. precisa gostar dela. } \\
\text { Vi um dado que só o fato de uına pessoa saber ler já aumenta o tempo de vida dela... se a } \\
\text { escola faz mais ainda, se preocupa com a saúde de dentre e de fora da escola, melhora ainda } \\
\text { mais. }\end{array}$ \\
\hline $\begin{array}{l}\text { 3. Contribuição pessoal para que a } \\
\text { escola seja saudável } \\
\text { 3.1. Assegurar condições básicas } \\
\text { para o bom funcionamento da } \\
\text { escola (condiçōes fisicas e materiais) }\end{array}$ & $\begin{array}{l}\text { D.1. Eu acho que a função do dirigente da Diretoria o envolvimento é o menor possivel. } \\
\text { Tenho que ter consciência de quais são as condições de que a escola necessita para se tornar } \\
\text { saudável e assegurar estas condições ... assegurar as condições fisicas e os materiais ... } \\
\text { funcionar como um elo entre a escola e o sistema, a Secretaria... } \\
\text { D.4. Eu tenho que dar tudo que a escola precisa. Corro atrás para que tudo fique em ordem, } \\
\text { para que o que se fez seja conservado ... administro bem os recursos, sempre junto com a } \\
\text { comunidade...acompanho o que está acontecendo, dou uma mãozinha aqui c ali. . }\end{array}$ \\
\hline 3.2. Fstimular a escola & $\begin{array}{l}\text { D.1. o meu papel é o de estimular a escola para que use bem suas condições fisicas e os } \\
\text { materiais de que dispõe para que ela faça um trabalho e seja boa e saudável } \\
\text { D.2. Eu tenho incentivado, nas minhas visitas, tenho feito sempre o discurso de que a escola } \\
\text { tem que caminhar no sentido de ser uma escola cada vez melhor e mais saudável }\end{array}$ \\
\hline $\begin{array}{l}\text { 3.3. Acompanhar e cobrar da escola } \\
\text { o processo de se tornar uma escola } \\
\text { saudácel }\end{array}$ & $\begin{array}{l}\text { D.1. Tenho que lembrar a escola das condiçôes que ela tem e do que é obrigada a oferecer à } \\
\text { comunidade. Então, cobrar da escola o dever que ela tem de ser uma escola boa e saudável, } \\
\text { dadas todas as condições que ela tem e que são favoráveis a esse projeto. } \\
\text { D.4. Acompanho o processo, da mesma maneira que dou uma mão e estimulo, também vou } \\
\text { cobrando aqui e ali, me certificando da necessidade de corrigir isto ou aquilo. Até sou chata, } \\
\text { mas este é o meu papel. }\end{array}$ \\
\hline
\end{tabular}




\begin{tabular}{|c|c|}
\hline \multicolumn{2}{|c|}{ CARACTERÍSTICAS DO PROCESSO DE CONSTRUÇÃO DE UMA ESCOLA SAUDÁVEL } \\
\hline IDÉIAS CENTRAIS & \begin{tabular}{|l|} 
EXPRESSÕES - CHAVE \\
\end{tabular} \\
\hline $\begin{array}{l}\text { 3.4. Incentivar a escola para que } \\
\text { trabalhe articuladamente com a } \\
\text { comunidade }\end{array}$ & $\begin{array}{l}\text { D.2. Bato sempre na mesma tecla .... escola tem que trabalhar com a comunidade, fazer com } \\
\text { que a comunidade assuma a escola, para que o trabalho da diretora e até do corpo docente } \\
\text { fique amenizado. Porque quando a comunidade assume a escola e os alunos incorporam } \\
\text { todos estes valores, o trabalho do diretor e do corpo docente é um trabalho mais tranqüilo, } \\
\text { mais ameno. Nas minhas visitas, tenho estimulado para que a escola abra as portas para a } \\
\text { comunidade, mas com trabalho, com organização. Não somente abrir as portas e deixar para } \\
\text { que a escola fique à mercê da comunidade. Não é isso mesmo? Tem que ser um trabalho } \\
\text { direcionado. }\end{array}$ \\
\hline $\begin{array}{l}\text { 3.5. Estabelecer canais de } \\
\text { comunicação entre os professores e } \\
\text { a familia dos alunos, para assegurar } \\
\text { a escolaridade básica ao aluno }\end{array}$ & $\begin{array}{l}\text { D.5. Acho que tenho colaborado para melhorar a relação da escola e dos professores com os } \\
\text { alunos e suas famílias. Eu aprendi a conviver com os alunos e seus problemas e tenho } \\
\text { procurado, sempre que possivel, colocar a familia em contato com a escola e a escola } \\
\text { também em contato com a casa do aluno. Ligo para mãe no serviço e me coloco à disposição } \\
\text { dela a qualquer hora. Controlo o aluno que estava cabulando - vou à quadra, pergunto ao } \\
\text { professo. Se a mãe não pode vir à reunião - e essas reuniões são muito importantes, pois se } \\
\text { discute nelas o trabalho da escola- eu me disponho a atendê-la em qualquer horário, á tarde, á } \\
\text { noite. E tem dado certo. Olha, no final do ano a gente está um caco fazendo tudo isto - é } \\
\text { desgastante. E chama pai, chama mãe, atende por telefone, É professor que me entrega } \\
\text { bilhete para eu entregar ao pai. E tem que pegar bilhete de mãe para entregar para professora, } \\
\text { Mas eu deixo bem claro...o professor acha que a partir do momento em que o aluno deu } \\
\text { problema, ele tem que ir correndo atrás do conselho tutelar. Mas eu acho que o caminho para } \\
\text { você fazer frente a essa violência que está ai é chamar a familia para a responsabilidade do } \\
\text { papel dela e aconselhar o aluno. Eu acho que o aconselhamento dá certo. Tem um aluno aqui } \\
\text { que se chama William, esse aluno nós ganhamos. Tem um que se chama Mauricio que se a } \\
\text { escola tivesse fechado a porta para ele, a rua tinha abraçado ele. Eu falo isto para os pais. Eu } \\
\text { falo que se a escola puser os alunos para fora da escola, a rua abraça. E quando a rua } \\
\text { devolver este aluno para os pais, ele já estará marcado, com seqüelas. Então nós temos que } \\
\text { abraçar aqui, na escola. Não podemos soltar. A escola tem que ser interessante, o aluno tem } \\
\text { que ser ouvido, tem que poder contar as suas experiências...Agora, se a gente abraçar e o pai } \\
\text { solta, a rua abraça. }\end{array}$ \\
\hline
\end{tabular}




\begin{tabular}{|c|c|}
\hline \multicolumn{2}{|c|}{ CARACTERISTICAS DO PROCESSO DE CONSTRUÇÃO DE UMA ESCOLA SAUDÁVEL } \\
\hline IDÉIAS CENTRAIS & EXPRESSÕES - CHAVE \\
\hline $\begin{array}{llr}\begin{array}{l}\text { 3.6. Aperfeiçoar } \\
\text { professores }\end{array} \text { relações entre } \\
\text { pedagogica } & \text { coordenação } \\
\text { (estabelecimento de clima de } \\
\text { honestidade e franqueza) }\end{array}$ & $\begin{array}{l}\text { D.5. Em primeiro lugar, eu sou honesta com as pessoas. Com os professores, procuro sempre } \\
\text { deixar as coisas muito claras - não guardo mágoa, mesmo quando tenho algum } \\
\text { desentendimento. Por exemplo, nos saímos em excursão e eu dividi a turma de um professor } \\
\text { - metade foi num ônibus, a outra metade, no outro ônibus. Nem percebi que dividi a turma, } \\
\text { mas tinha gente que cuidava dos alunos dos dois ônibus e estava tudo sob controle. A } \\
\text { professora ficou muito brava. Reclamou muito - eu não liguei e não fiquei com raiva. } \\
\text { Noutro dia, conversamos normal e ela pediu desculpas. }\end{array}$ \\
\hline 3.7.Disponibilidade para o diálogo & $\begin{array}{l}\text { D.3. acho que a minha participação é sempre estar conversando com os alunos, com os } \\
\text { colegas...é sempre estar pronto para bater papo. Quando eu estou mal, eles percebem. Às } \\
\text { vezes eu chego brincando na sala de aula e eles percebem : "você não está legal hoje". Eu } \\
\text { acho muito doido quando chego na sala de aula e percebo que um aluno meu não está bem! } \\
\text { Por exemplo, ver um aluno de } 8^{\prime} \text { ou do Ensino Médio desabar na minha frente. Quando } \\
\text { alguém não está bem, eu pergunto e converso sempre. Eu acho mesmo que a minha } \\
\text { participação é a minha disposição para o diálogo. }\end{array}$ \\
\hline $\begin{array}{l}\text { 3.8. Ampliar oportunidades de } \\
\text { participação dos alunos em jogos e } \\
\text { competições }\end{array}$ & $\begin{array}{l}\text { D.9. Acho que me esforço muito para que a escola seja saudável. Os meus alunos sempre } \\
\text { participaram de campeonatos ...sempre fomos premiados e nos destacamos em todas as } \\
\text { competições. Participamos nos Jogos Municipais, nos Jogos da Caixa ... Eles ficavam } \\
\text { sempre muito satisfeitos ... alguns não se tocavam e não queriam participar. É dificil trazer } \\
\text { este pessoa para a quadra, mas a participação geral sempre foi boa. Os pais ficavam sempre } \\
\text { muito satisfeitos com os resultados e isso os aproximava mais ainda da escola. }\end{array}$ \\
\hline $\begin{array}{l}\text { 3.9. Compromisso com } \text { a } \\
\text { aprendizagem do aluno em sala de } \\
\text { aula }\end{array}$ & $\begin{array}{l}\text { D.10. Estou sempre me aprimorando e busco trazer coisas novas e interessantes para o aluno. } \\
\text { Procuro o que tem de bom por ai e trago para cá, fazendo com que o aluno se expresse de } \\
\text { várias maneiras, usando várias linguagens...tem aquele aluno que não é bom numa área, mas } \\
\text { é bom em outra - se ele não é bom em Música, ele é bom em outra coisa ...eu dou } \\
\text { oportunidades para que todos se sintam capazes ....para que eles se valorizem, tenham êxito, } \\
\text { aceitem as diferenças, contribuam para o coletivo. Também busco interagir com os meus } \\
\text { colegas, para que eles aproveitem o que puderem das coisas que eu arranjo fora. }\end{array}$ \\
\hline
\end{tabular}




\begin{tabular}{|c|c|}
\hline \multicolumn{2}{|c|}{ CARACTERÍSTICAS DO PROCESSO DE CONSTRUÇÃO DE UMA ESCOLA SAUDÁVEL } \\
\hline IDÉIAS CENTRAIS & EXPRESSÕES - CHAVE \\
\hline $\begin{array}{l}\text { 3.9. Compromisso com } \quad \text { a } \\
\text { aprendizagem do aluno em sala de } \\
\text { aula }\end{array}$ & $\begin{array}{l}\text { D.12. Trabalho sempre para o aluno. Eles não acham minha matéria fácil e eu me esforço } \\
\text { para que eles possam perder o medo, interessar-se pelas aplicações da Matemática e } \\
\text { aprenderem o que eu ensino. Quando alguma coisa dá errado, falo com a coordenação, } \\
\text { converso com os pais. Acho que colaboro para que o aluno fique na escola, seja bem } \\
\text { sucedido - e eu não entendo que alguém possa ser saudável se é expulso da escola sem } \\
\text { acabar o seu curso. }\end{array}$ \\
\hline $\begin{array}{l}\text { 3.10. Fstímulo à participação de } \\
\text { todos e para melhorar a auto-estima } \\
\text { de carla um }\end{array}$ & $\begin{array}{l}\text { D.4. Aproximo as pessoas, sistematizo as nossas prioridades. Estimulo a participação de } \\
\text { todos, busco manter elevada a auto-estima de cada um e da equipe...nem sempre a gente } \\
\text { consegue, mas a gente sente que é importante e corre atrás. }\end{array}$ \\
\hline$\longdiv { 3 . 1 1 . \text { Aloord } }$ & $\begin{array}{l}\text { D.6. Acho que a minha unica contribuição é trabalhar bem com os temas de saude. Os alunos } \\
\text { se interessam muito pelas discussões sobre sexualidade, DSTs, AIDS, gravidez, aborto...eles } \\
\text { são adolescentes e estão vivendo esta fase. Não se trata apenas de passar informações, mas } \\
\text { de dar um espaço para que eles possam discutir essas coisas que nem todos podem conversar } \\
\text { na casa. }\end{array}$ \\
\hline 3.12. Sintonia com & $\begin{array}{l}\text { D.10. Eu procuro estar sintonizada com tudo ...com o trabalho, com o bom relacionamento } \\
\text { com o aluno, com os colegas, com a comunidade. }\end{array}$ \\
\hline $\begin{array}{l}\text { 4. Receio quanto à descontinuidade } \\
\text { do projeto da escola } \\
\text { 4.1. Mudanças na composição da } \\
\text { equipe escolar }\end{array}$ & $\begin{array}{l}\text { D.3. A integração demora porque a educação passa por mudanças todo ano. E nisso, todo } \\
\text { trabalho é quebrado e você vai de novo colocando aquele tijolinho. Ai, chega no final do ano } \\
\text { - quebra. Sempre ficam algumas pessoas. E você consegue construir. E dá uma quebrada, } \\
\text { mas vocé vai moldando de novo. Mas podia ser mais fácil ...a gente sempre fica com medo } \\
\text { do que vai acontecer no próximo ano, se a equipe vai continuar na escola... }\end{array}$ \\
\hline
\end{tabular}




\begin{tabular}{|c|c|}
\hline \multicolumn{2}{|c|}{ CARACTERÍSTICAS DO PROCESSO DE CONSTRUÇÃO DE UMA ESCOLA SAUDÁVEL } \\
\hline IDÉIAS CENTRAIS & EXPRESSÕES - CHAVE \\
\hline $\begin{array}{l}\text { 4. Receio quanto à descontinuidade } \\
\text { do projeto da escola } \\
\text { 4.2. Distanciamento da família das } \\
\text { tarefas de acompanhamento da vida } \\
\text { escolar dos filhos }\end{array}$ & $\begin{array}{l}\text { D.5. A familia está se distanciando muito dos filhos. Com o desemprego, as mães empregam } \\
\text { no que der .... diarista, qualquer horário. Ficam mais distantes da responsabilidade de zelar, } \\
\text { conosco, pelos filhos. Confesso que tenho receio de que os pais não continuem no mesmo } \\
\text { ritmo de sempre. No ano passado, um aluno cabulava aula todos os dias. Liguei para a mãe, } \\
\text { várias vezes. Ela ficou irritada e disse que era papel da escola resolver disso. Se a familia } \\
\text { perder este referencial - não se sentir responsável - vai ser mais dificil. Tem pais que } \\
\text { querem saber que os fillhos estão aqui dentro e mais nada. E assim não anda. Na recuperação } \\
\text { de janeiro, achei que as mães ficaram pensando que os filhos poderão folgar durante o ano } \\
\text { todo, pois terão recuperação nas férias. Tenho receio de que a violência aumente ...num final } \\
\text { de semana, fizemos uma atividade - entrou uma gangue e veio um garoto de fora armado } \\
\text { aqui, para falar com uma aluna. Um professor enfrentou a gangue ...tenho medo que as } \\
\text { coisas possam mudar. Temos que pensar muito porque a violência é alguma coisa que mina } \\
\text { o trabalho da escola }\end{array}$ \\
\hline $\begin{array}{l}\text { 4. Receio quanto à descontinuidade } \\
\text { do projeto da escola } \\
\text { 4.3. Displicência dos profissionais } \\
\text { motivada pela confusão entre } \\
\text { progressão continuada e promoção } \\
\text { automática }\end{array}$ & $\begin{array}{l}\text { D.6. Tenho sempre medo das reformas da Secretaria. A progressão continuada pode deixar } \\
\text { as pessoas displicentes, pois elas não entendem o espirito da coisa ...só registram que o } \\
\text { Estado quer aprovar todo mundo e ficam desmotivados para fazer um trabalho sério na } \\
\text { escola.. Além disso, as novas diretrizes da Delegacia dificultam que a gente ofereça } \\
\text { atividades de lazer. A antiga direção proibia a ida ao Play Center. Fomos no ano passado, } \\
\text { mas este ano, quando fomos montar os projetos, já veio uma norma da Delegacia de Ensino } \\
\text { dizendo que não pode montar um projeto, em hipótese alguma, que envolva lazer. Este } \\
\text { parque novo de Jundiai, levar no SESC... mesmo se você quiser direcionar o projeto e fazer } \\
\text { uma aula passeio, você tem que envolver vários disciplinas. Eu acho que restringe um pouco. }\end{array}$ \\
\hline $\begin{array}{l}\text { 4.4. Abertura excessiva da } \\
\text { troca de professores }\end{array}$ & $\begin{array}{l}\text { D.7. Trabalho há muito tempo nesta escola e tenho receio quando vejo que a escola tem que } \\
\text { se abrir para tanta coisa. Fico com medo também das reformas da Secretaria e de que a gente } \\
\text { fique trocando muito de professor - assim não dá nem para ver o resultado do traballo de } \\
\text { cada um e do grupo } \\
\text { D. } 10 \text {. As pessoas aqui se acostumaram a uma sistemática de trabalho coletivo e a gente tem } \\
\text { até medo das mudanças da Secretaria que possam acabar com este trabalho. Sei lá ...um } \\
\text { sistema diferente de contratar professores, uma nova reorganização... }\end{array}$ \\
\hline
\end{tabular}




\section{ANEXO 8}

Fotografias da escola

e expressões-chave 


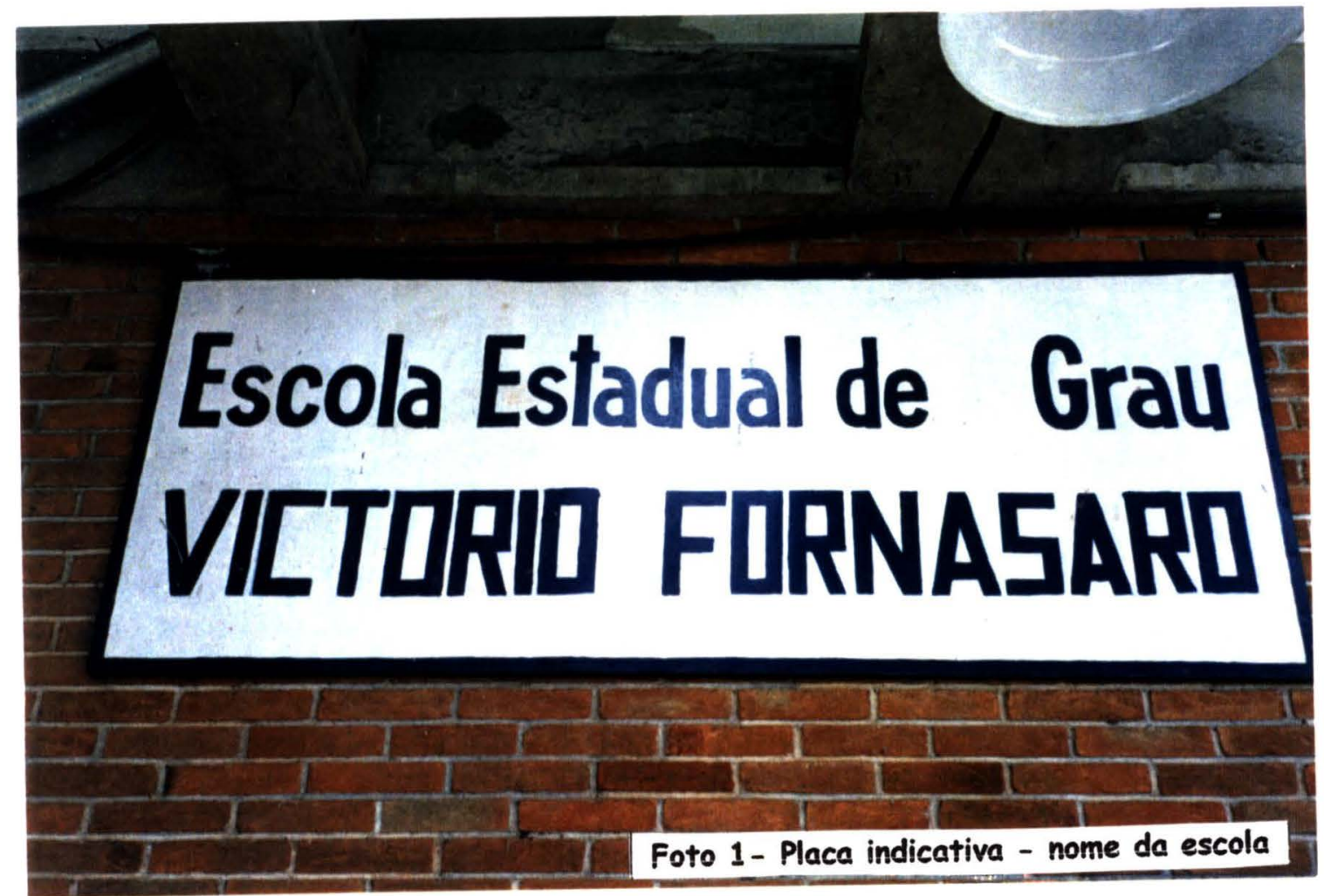

"...o prédio é bem construído.... a escola é muito arborizada..."

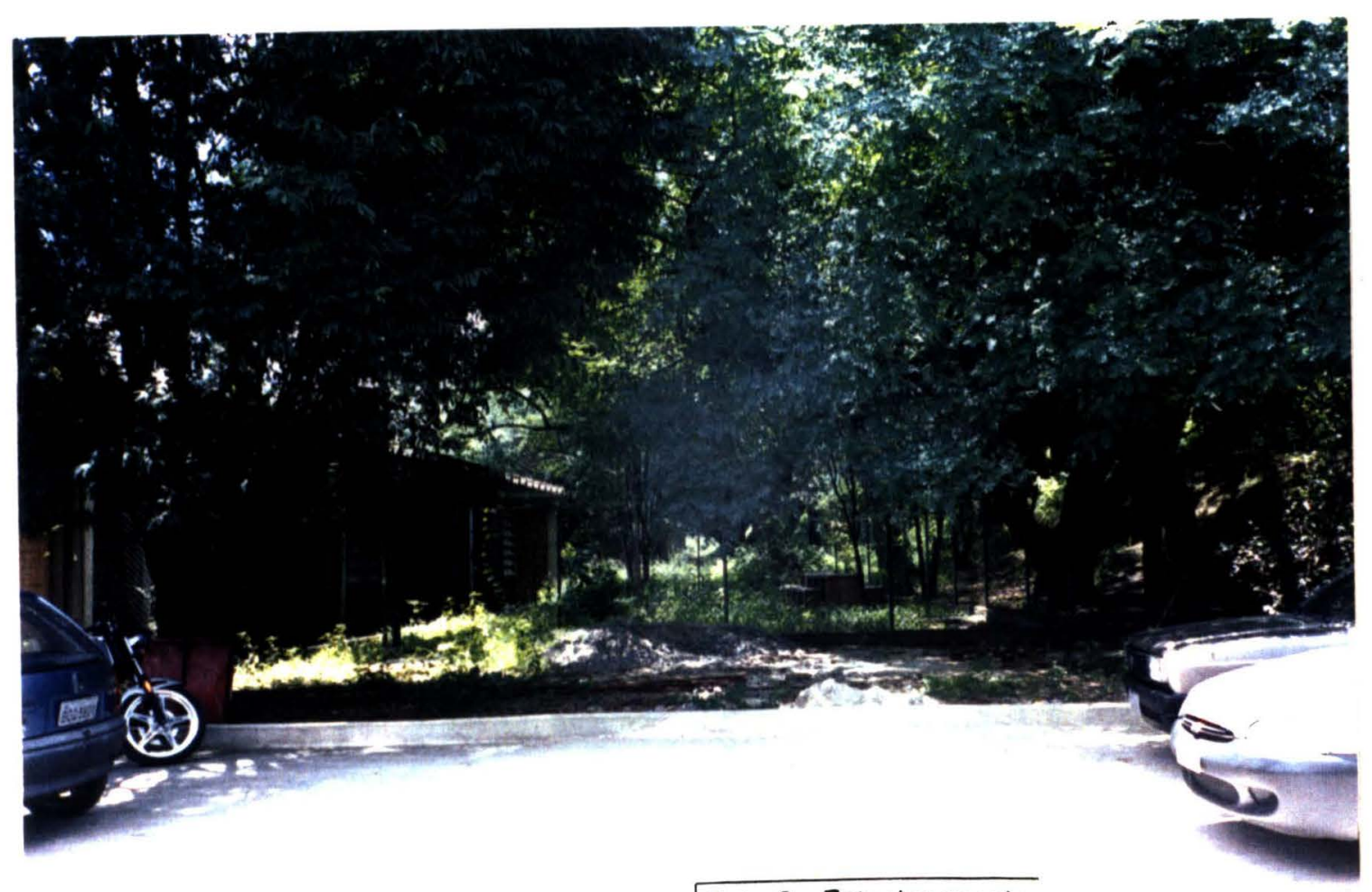

Foto 2 - Estacionamento 

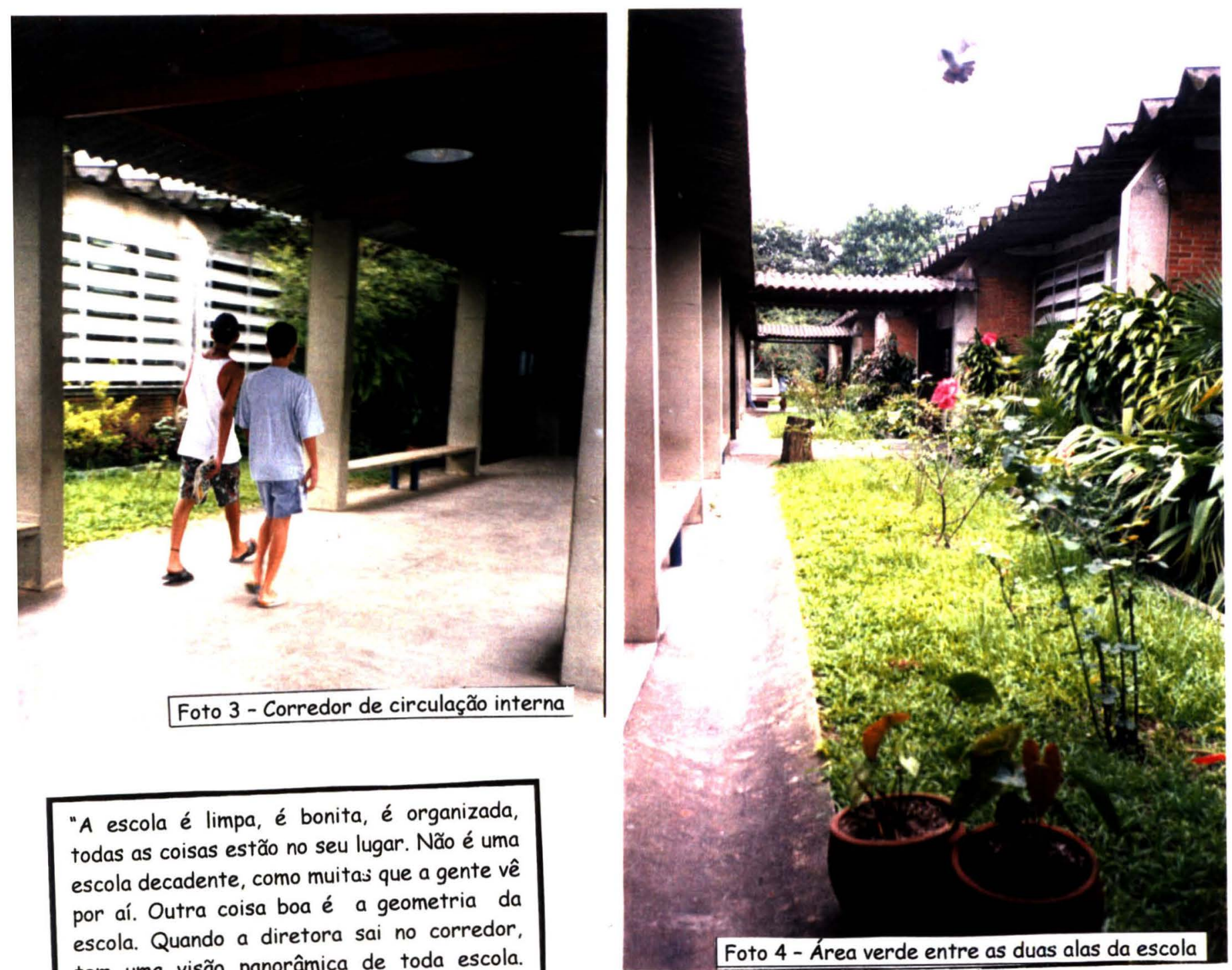

"A escola é limpa, é bonita, é organizada, todas as coisas estão no seu lugar. Não é uma escola decadente, como muitas que a gente vê por aí. Outra coisa boa é a geometria da escola. Quando a diretora sai no corredor. tem uma visão panorâmica de toda escola. Aqui não tem grades, nem andares ...não há portões trancados, ninguém fica isolado"

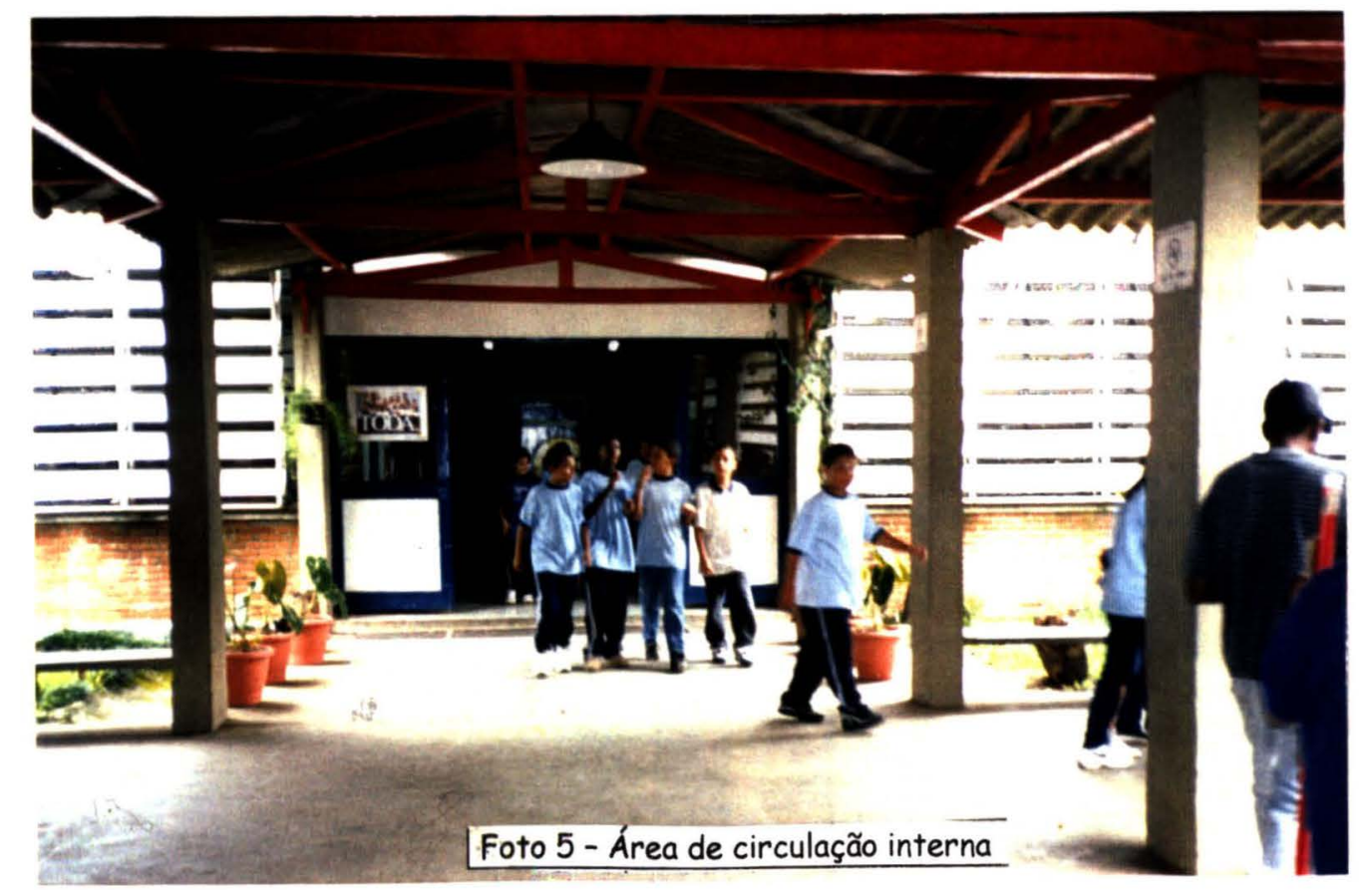

"Estava querendo dizer que uma escola saudável é em princípio uma boa escola. A escola não é um hospital... é uma escola. E faz parte de ser saudável que ela faça bem o que precisa fazer, o que é só ela que faz ..." 

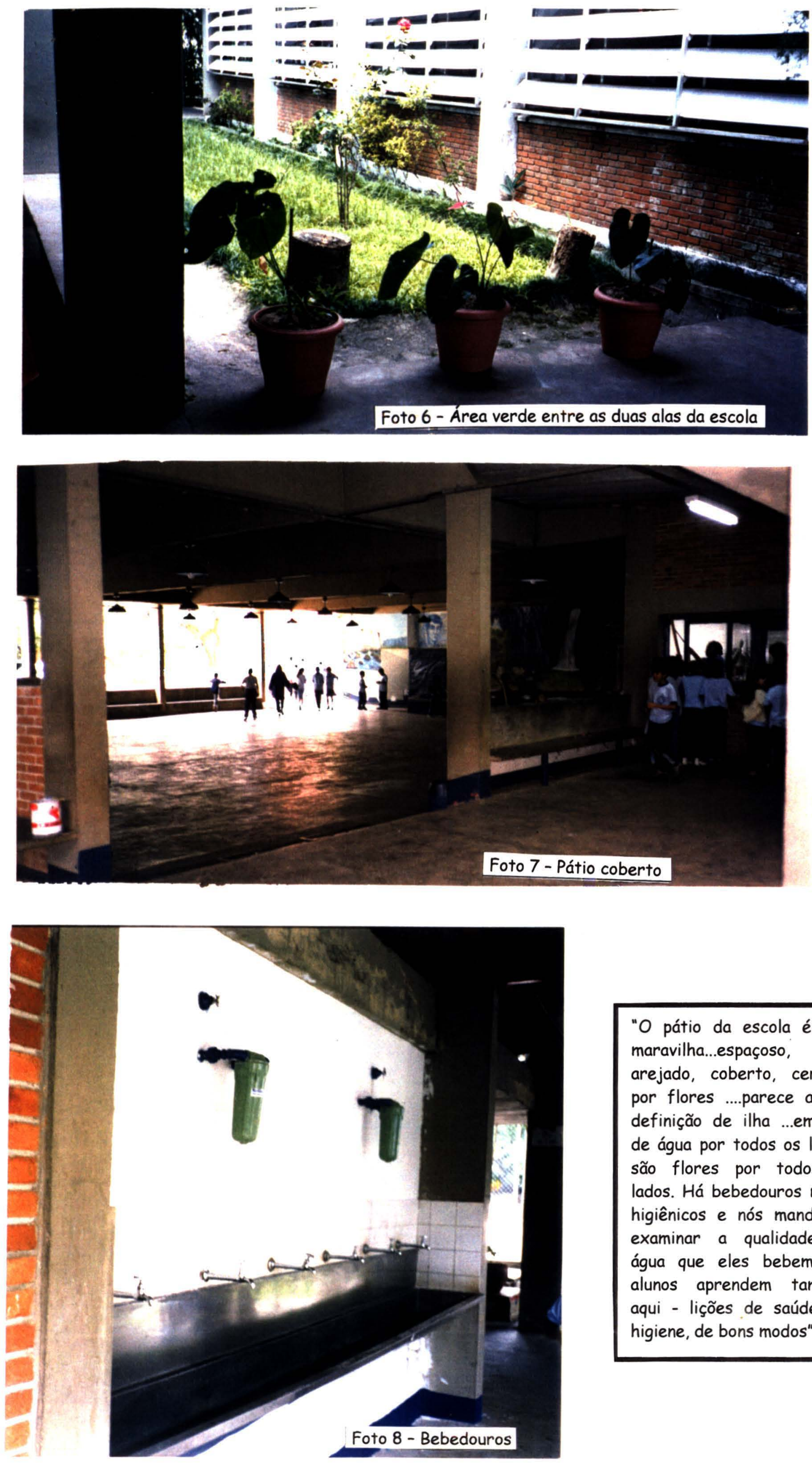

"O pátio da escola é uma maravilha...espaçoso,

arejado, coberto, cercado por flores ....parece aquela definição de ilha ...em vez de água por todos os lados, são flores por todos os lados. Há bebedouros muito higiênicos e nós mandamos examinar a qualidade da água que eles bebem. Os alunos aprendem também aqui - lições de saúde, de higiene, de bons modos" 

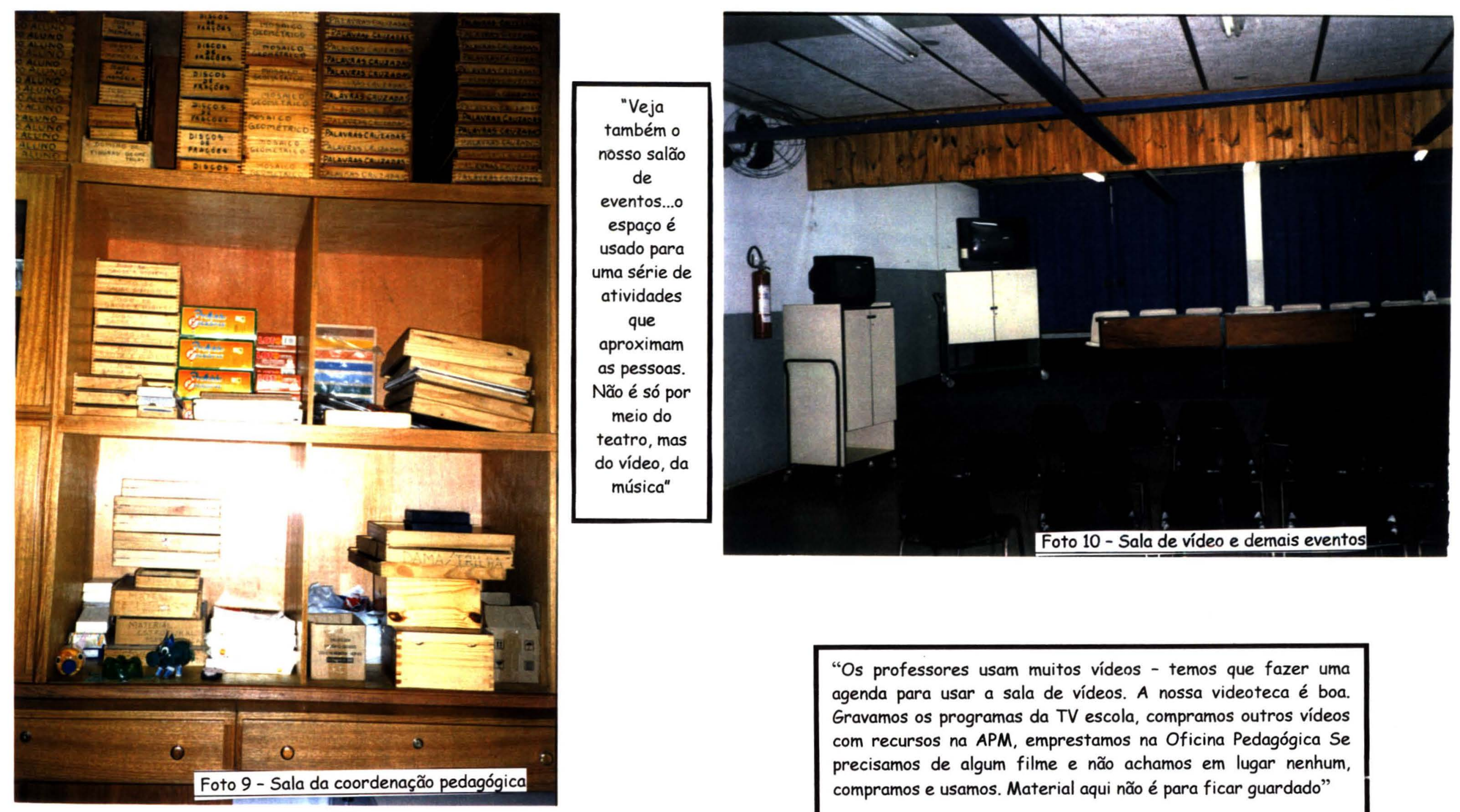

"Esta é uma boa escola, rica em materiais didáticos; a gente tem acesso a este material, dá para fazer um trabalho bom com ele"

"Os professores usam muitos vídeos - temos que fazer uma agenda para usar a sala de vídeos. A nossa videoteca é boa. Gravamos os programas da TV escola, compramos outros vídeos com recursos na APM, emprestamos na Oficina Pedagógica Se precisamos de algum filme e não achamos em lugar nenhum, compramos e usamos. Material aqui não é para ficar guardado" 

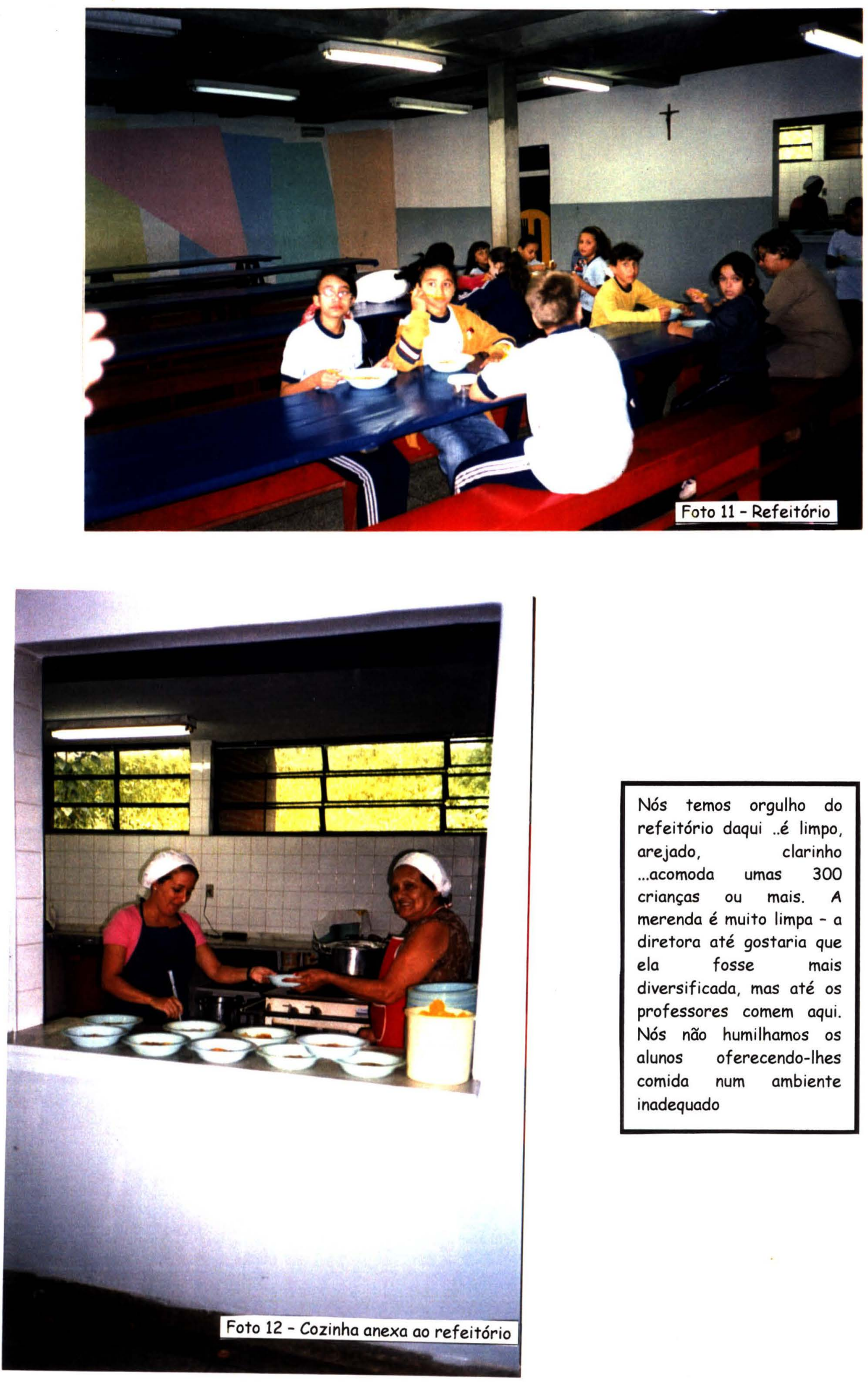

Nós temos orgulho do refeitório daqui ..é limpo, arejado, clarinho ...acomoda umas 300 crianças ou mais. $A$ merenda é muito limpa - a diretora até gostaria que ela fosse mais diversificada, mas até os professores comem aqui. Nós não humilhamos os alunos oferecendo-lhes comida num ambiente inadequado 


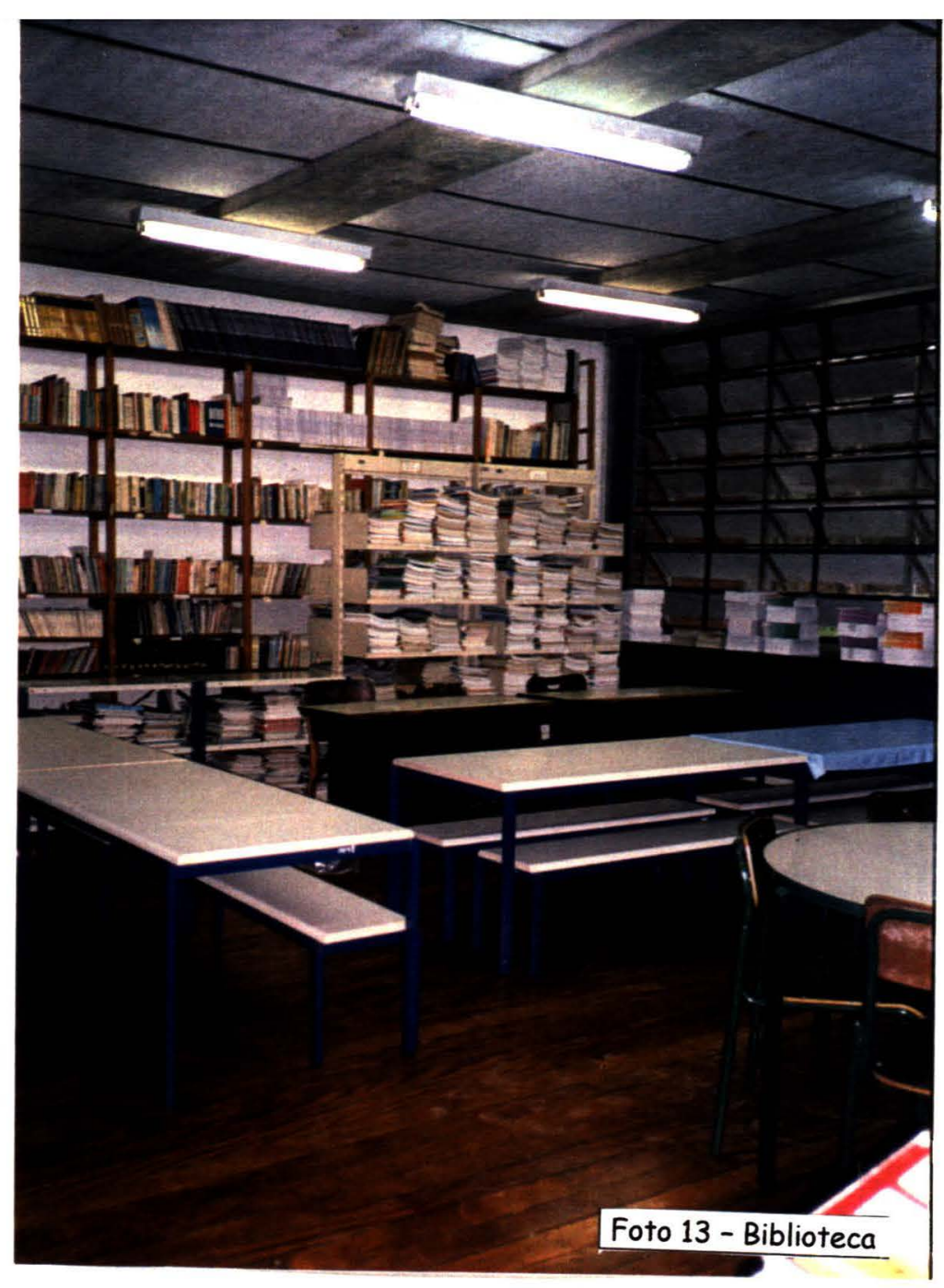

"A. nossa biblioteca é muito boa.. uma professora aposentada toma conta ... assim, os nossos alunos têm mais oportunidade de voltar à escola para consultas, de gostar mais da escola"
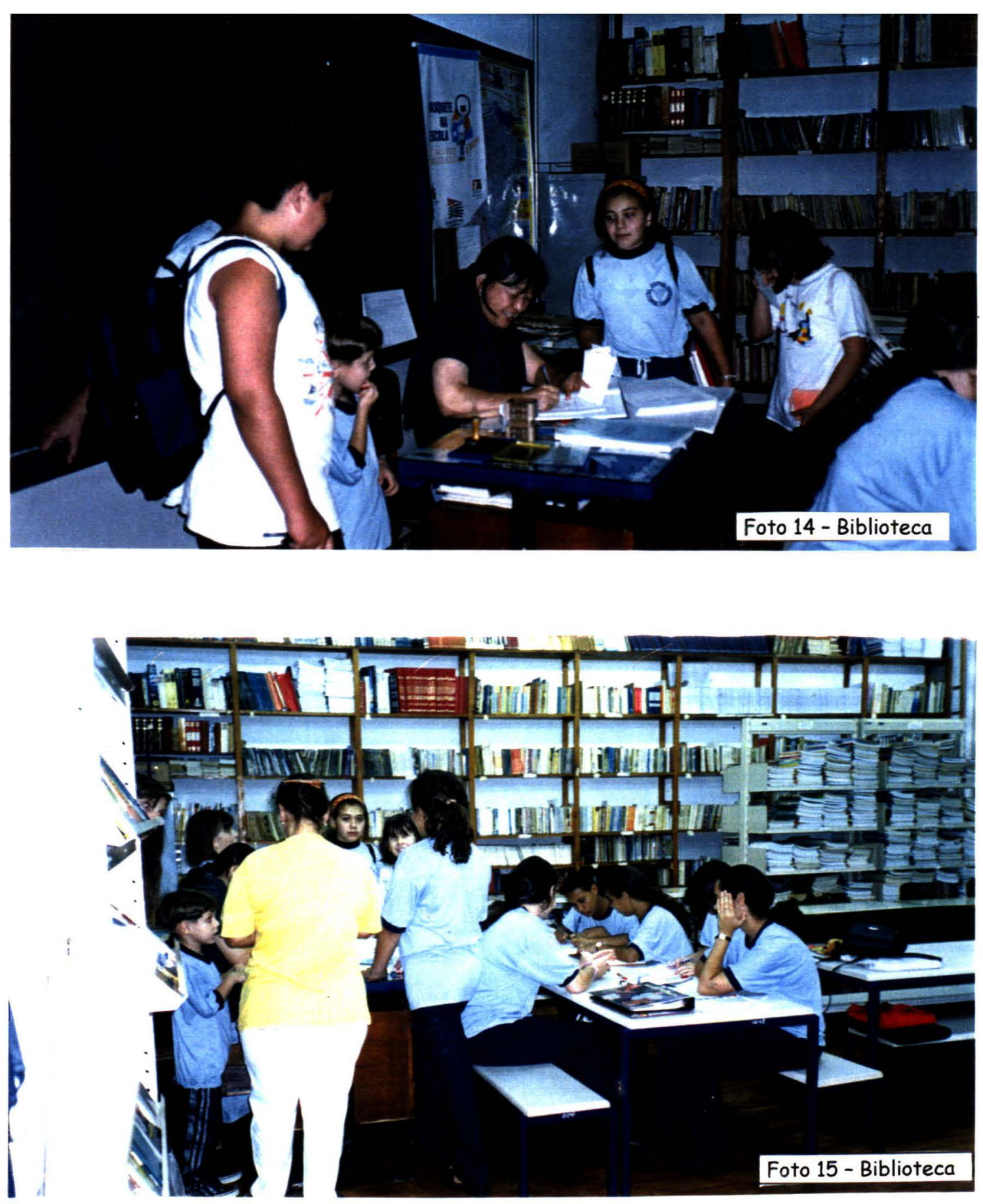


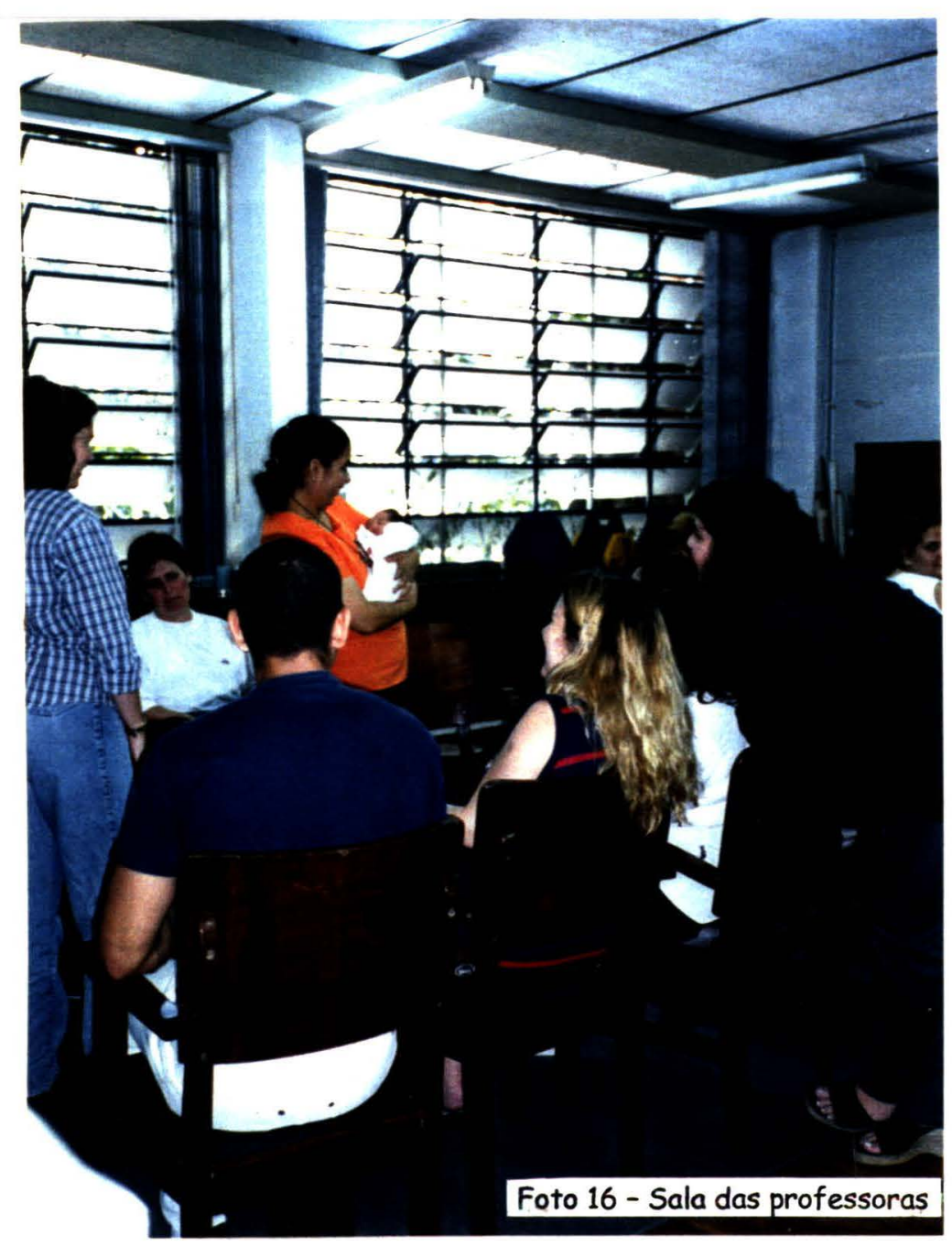

"a sala de professores é um lugar muito saudável ...uma mesa grande, onde as pessoas sempre estão se reunindo, trocando coisas ... um cantinho mais aconchegante, que deixa a sala com a cara da casa da gente"
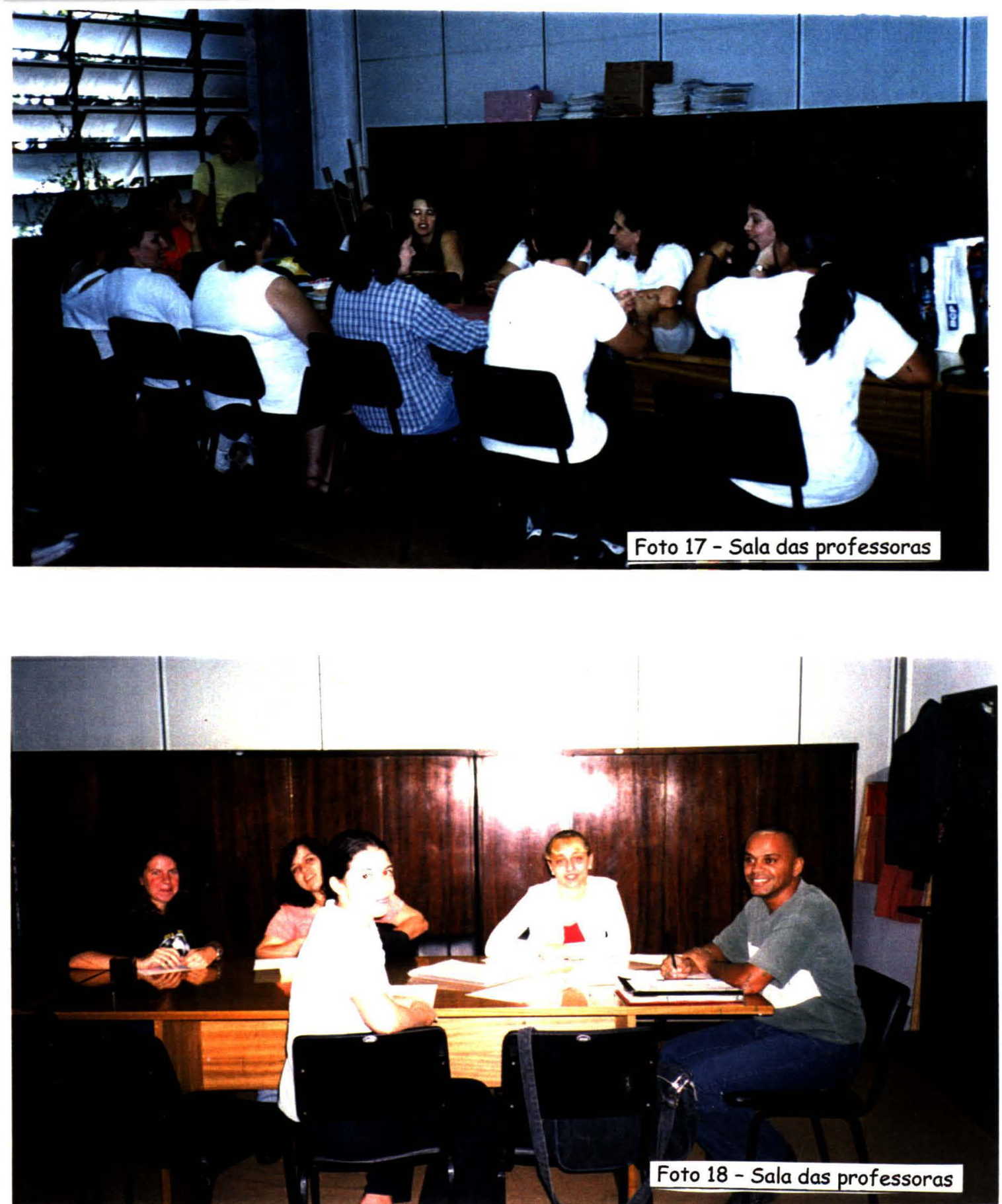


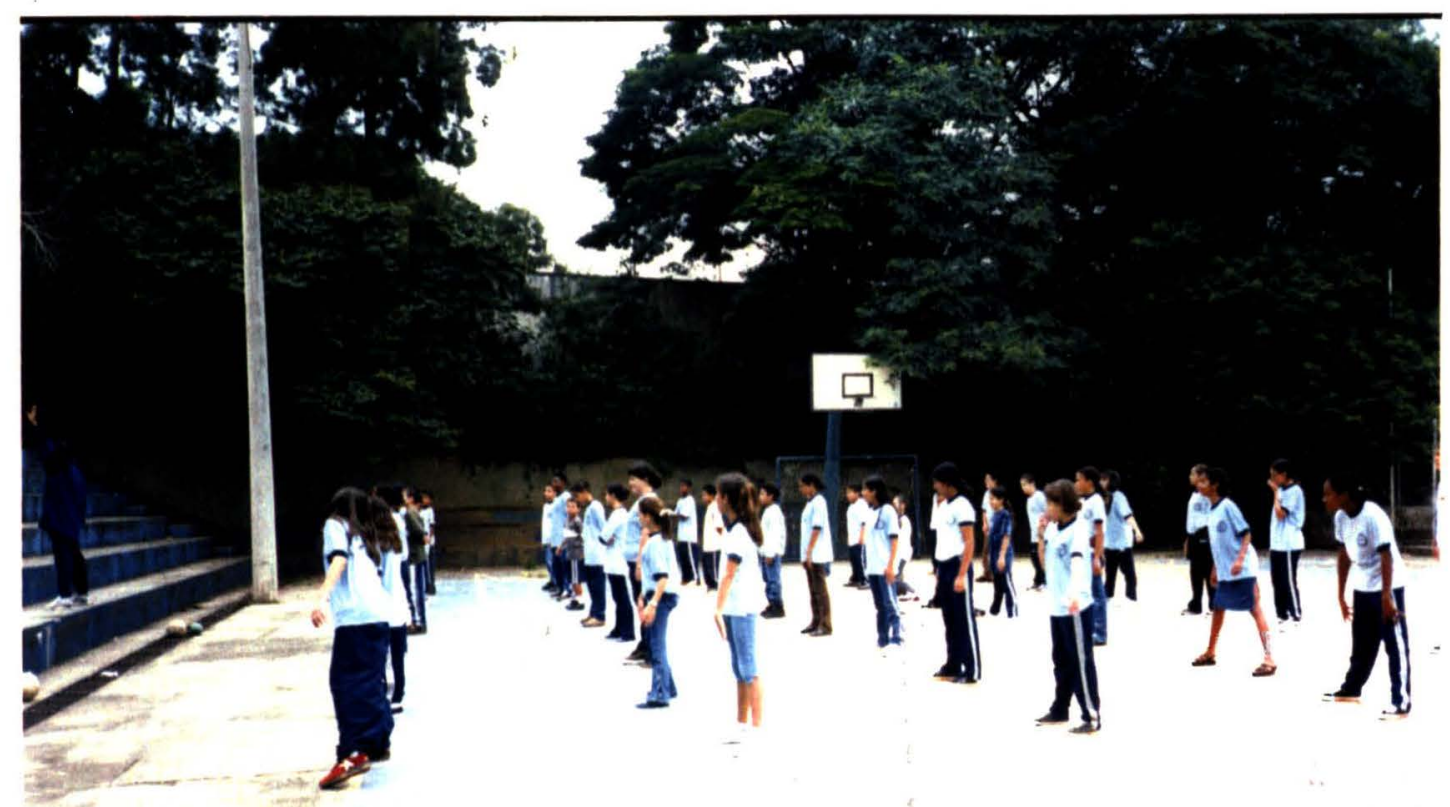

Foto 19 - Quadra esportiva

"Os alunos sempre participaram de campeonatos ...sempre fomos premiados e nos destacamos em todas as competições. Participamos nos Jogos Municipais, nos Jogos da Caixa .... Eles ficam sempre muito satisfeitos. Os pais ficavam sempre muito satisfeitos com os resultados $e$ isso os aproximava mais ainda da escola"

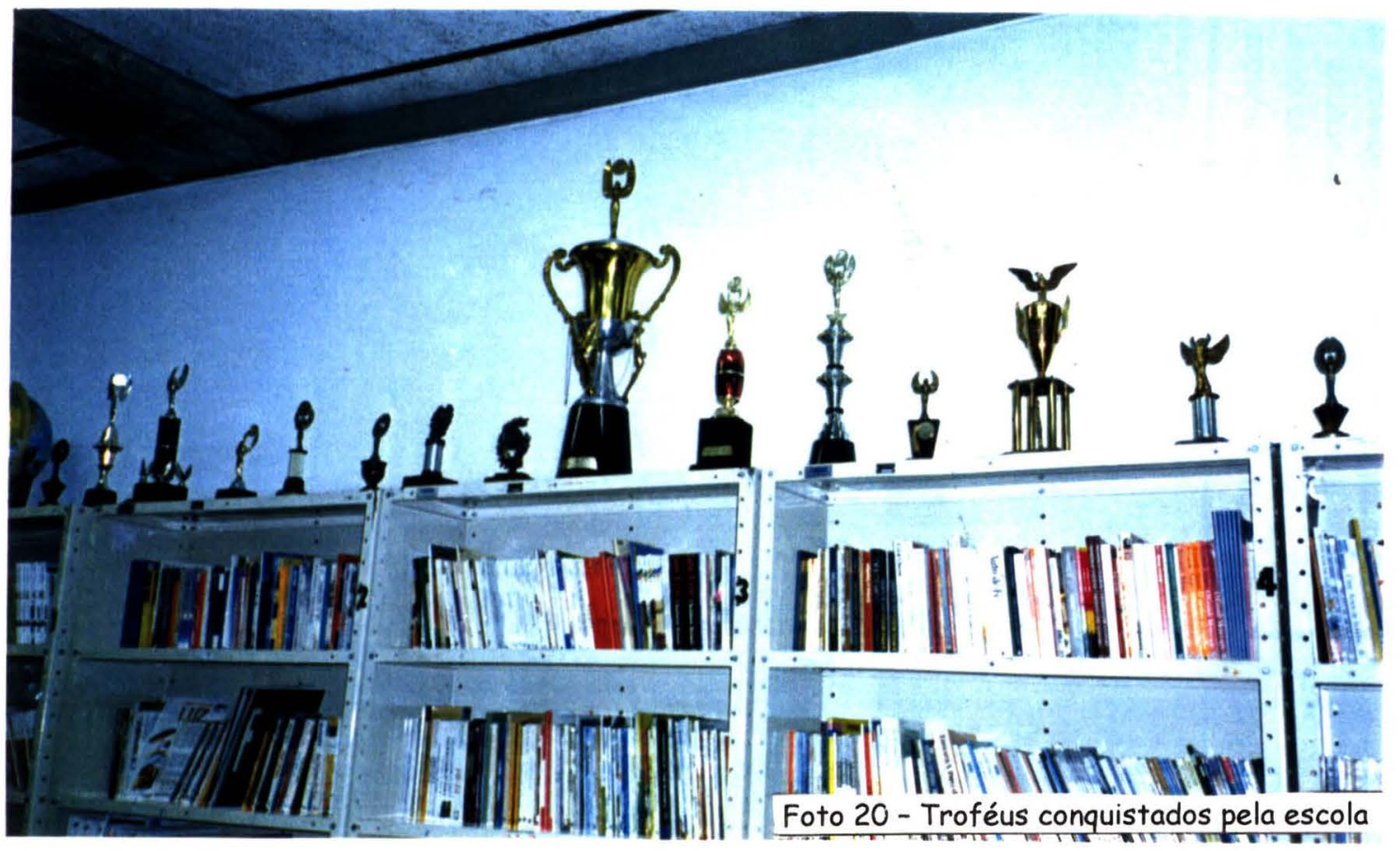



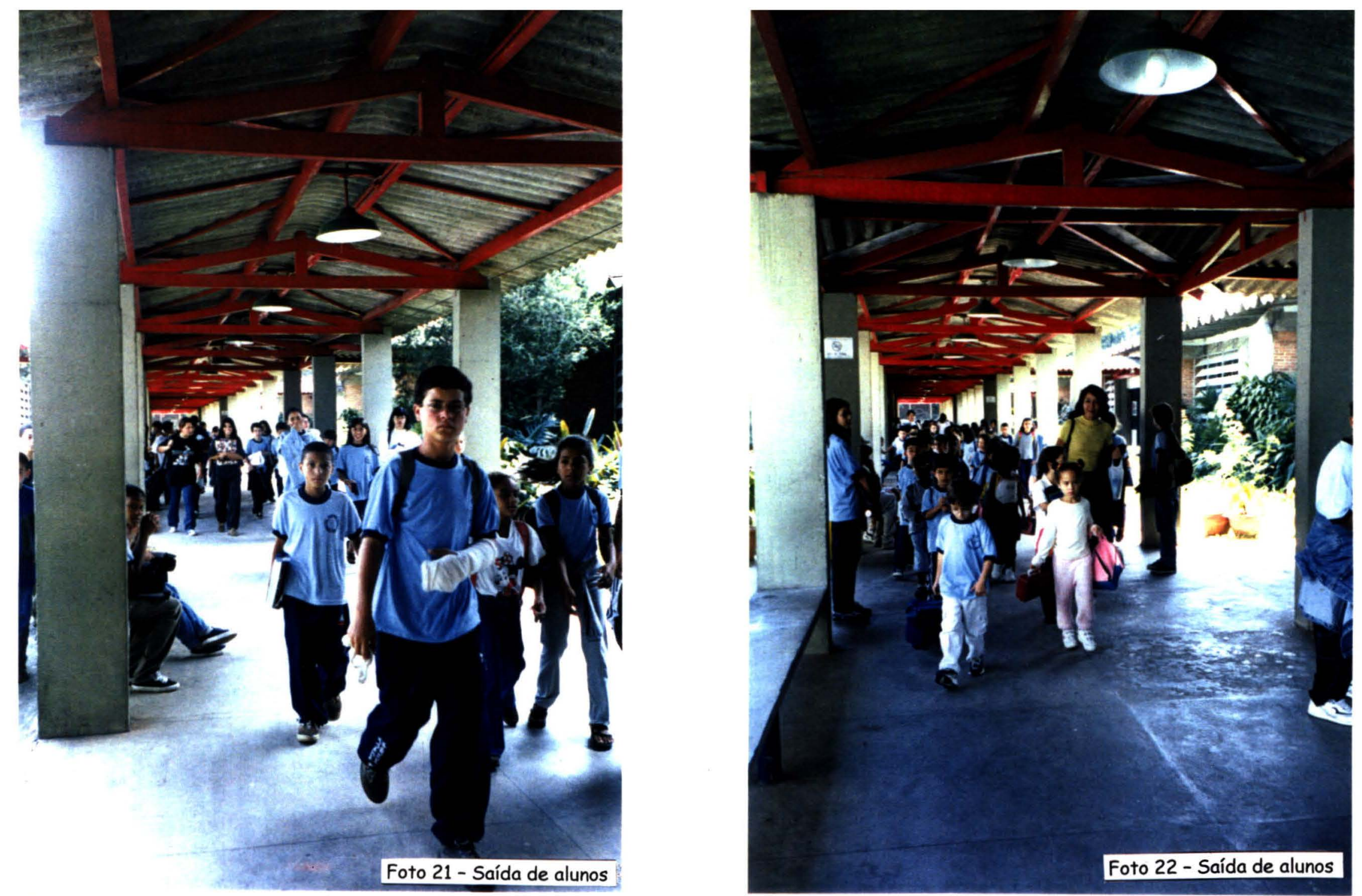

"Os alunos procuram estar uniformizados, procuram se vestir bem. Procuram se pentear. Procuram estar bem - vamos dizer tomar banho. Os alunos procuram andar de maneira comportada, mais bonita. Dificilmente se vê aluno correndo, suado e a gente percebe isto"

"Viu como os alunos caminham nas passarelas? O que fazem?! Eles andam, mas sem se atropelar, sem trombar uma na outra... $\circ$ grande convive com $\circ$ pequeno $e$ você nota que existe um respeito um pelo outro" 

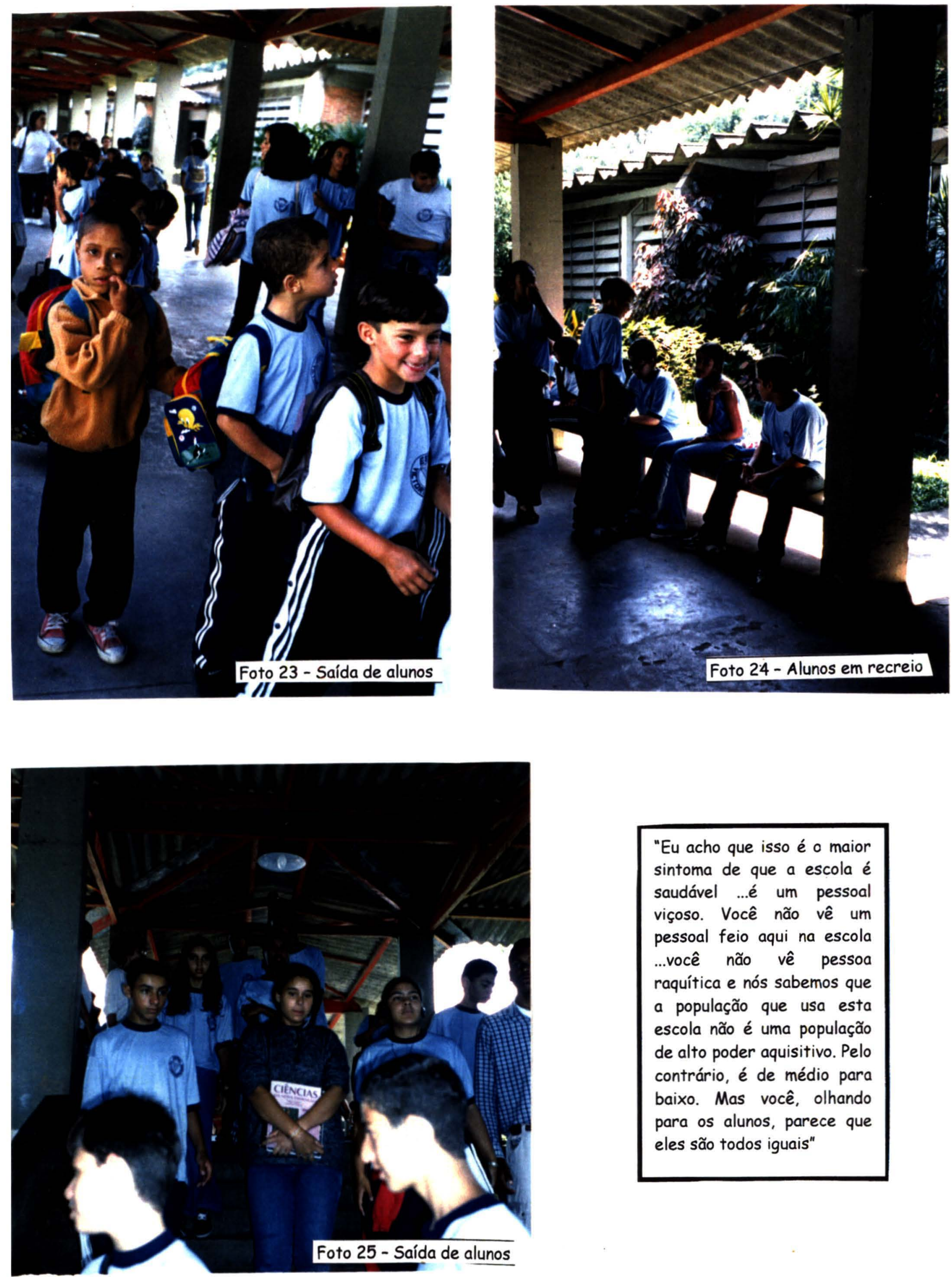

"Eu acho que isso é o maior sintoma de que a escola é saudável ...é um pessoal viçoso. Você não vê um pessoal feio aqui na escola ...você não vê pessoa raquítica e nós sabemos que a população que usa esta escola não é uma população de alto poder aquisitivo. Pelo contrário, é de médio para baixo. Mas você, olhando para os alunos, parece que eles são todos iguais" 

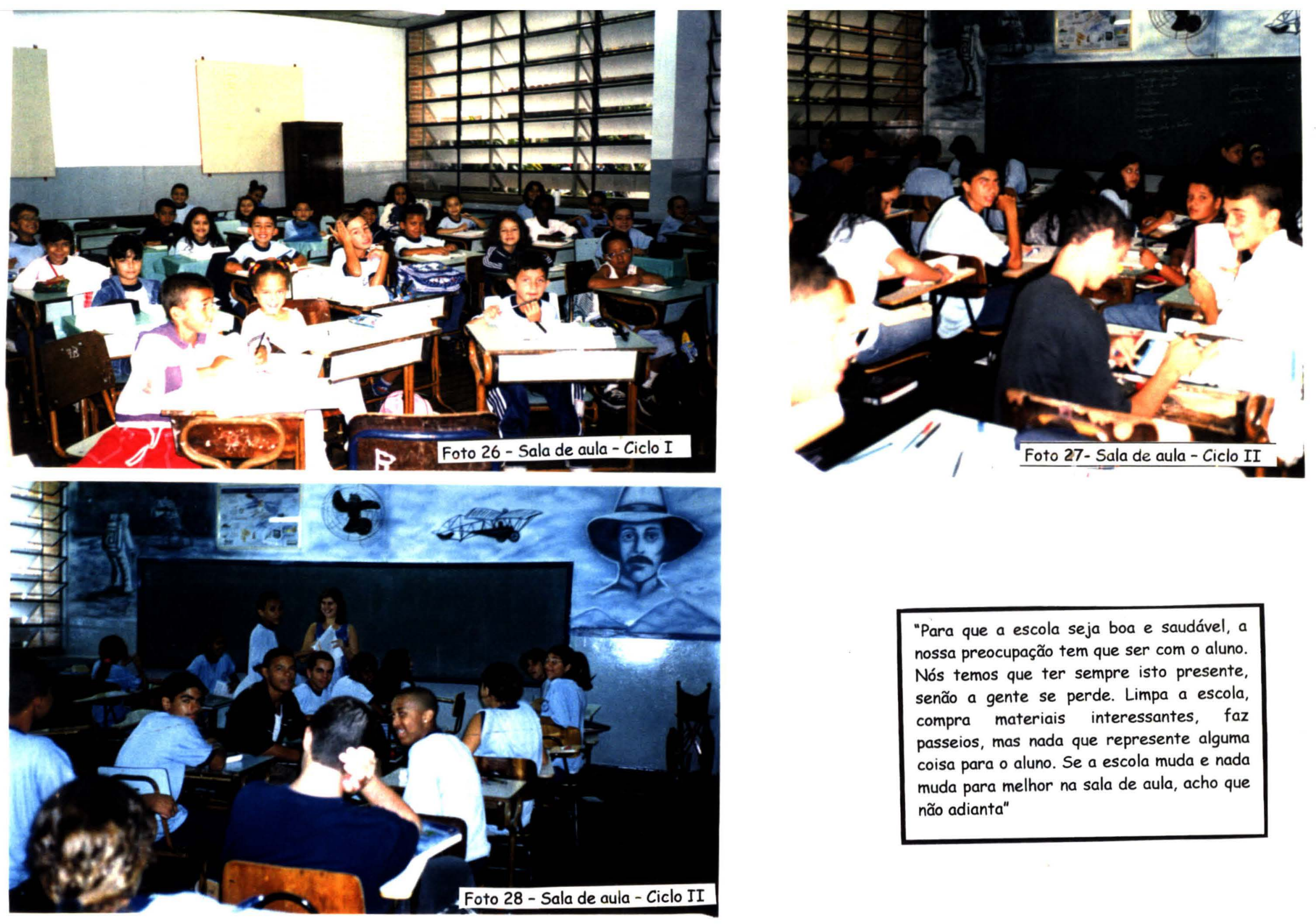

"Para que a escola seja boa e saudável, a nossa preocupação tem que ser com o aluno. Nós temos que ter sempre isto presente, senão a gente se perde. Limpa a escola, compra materiais interessantes, $\mathrm{faz}$ passeios, mas nada que represente alguma coisa para o aluno. Se a escola muda e nada muda para melhor na sala de aula, acho que não adianta" 

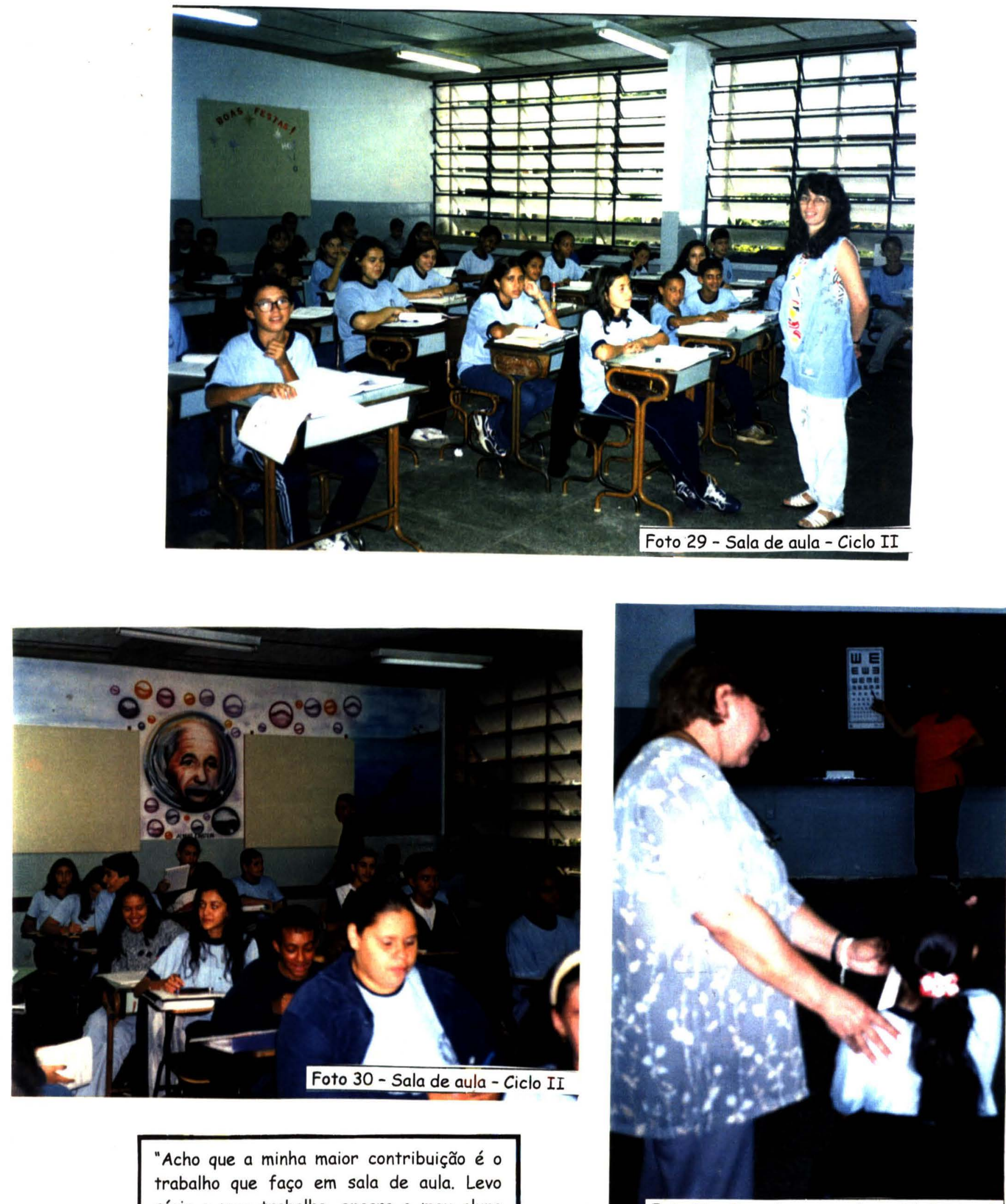
trabalho que faço em sala de aula. Levo sério o meu trabalho, encaro o meu aluno como uma pessoa, me empenho para saber o

Foto 31 - Cena de exame de acuidade visual que ele já sabe e fazer ele crescer.... eles se valorizam mais $e$ viram gente grande, boa, saudável, que sabe o que quer, que sabe fazer, que sabe conseguir as coisas. $\mathrm{Se}$ todos os professores fizerem assim acho que é muito" 